BNL-94223-2010-IR

\title{
A Study of a Diesel Engine Based Micro-CHP System
}

\author{
C.R. Krishna, John Andrews, Narinder Tutu, Thomas Butcher
}

August 31, 2010

\author{
Sustainability Energy Technologies Department \\ Brookhaven National Laboratory
}

\author{
U.S. Department of Energy \\ [DOE Program Office], [DOE Sub-program]
}

Notice: This manuscript has been authored by employees of Brookhaven Science Associates, LLC under Contract No. DE-AC02-98CH10886 with the U.S. Department of Energy. The publisher by accepting the manuscript for publication acknowledges that the United States Government retains a non-exclusive, paid-up, irrevocable, world-wide license to publish or reproduce the published form of this manuscript, or allow others to do so, for United States Government purposes. 


\section{DISCLAIMER}

This report was prepared as an account of work sponsored by an agency of the United States Government. Neither the United States Government nor any agency thereof, nor any of their employees, nor any of their contractors, subcontractors, or their employees, makes any warranty, express or implied, or assumes any legal liability or responsibility for the accuracy, completeness, or any third party's use or the results of such use of any information, apparatus, product, or process disclosed, or represents that its use would not infringe privately owned rights. Reference herein to any specific commercial product, process, or service by trade name, trademark, manufacturer, or otherwise, does not necessarily constitute or imply its endorsement, recommendation, or favoring by the United States Government or any agency thereof or its contractors or subcontractors. The views and opinions of authors expressed herein do not necessarily state or reflect those of the United States Government or any agency thereof. 


\title{
A STUDY OF A DIESEL ENGINE BASED MICRO-CHP SYSTEM
}

Final Report

Prepared for

THE NEW YORK STATE

ENERGY RESEARCH AND DEVELOPMENT AUTHORITY

Albany, NY

Gregory A. Pedrick, C.E.M.

Project Manager Buildings R\&D

\author{
Submitted by \\ Brookhaven National Laboratory \\ Upton, NY \\ C. R. Krishna \\ Principal Investigator \\ Prepared by \\ Brookhaven National Laboratory \\ Upton, NY \\ C R Krishna \\ John Andrews \\ Narinder Tutu \\ Thomas Butcher
}

NYSERDA Contract \# 10370

August 2010 


\section{NOTICE}

This report was prepared by Brookhaven National Laboratory (BNL) in the course of performing work contracted for and sponsored by the New York State Energy Research and Development Authority (hereafter "NYSERDA"). The opinions expressed in this report do not necessarily reflect those of NYSERDA or the State of New York, and reference to any specific product, service, process, or method does not constitute an implied or expressed recommendation or endorsement of it. Further, NYSERDA, the State of New York, and the contractor make no warranties or representations, expressed or implied, as to the fitness for particular purpose or merchantability of any product, apparatus, or service, or the usefulness, completeness, or accuracy of any processes, methods, or other information contained, described, disclosed, or referred to in this report. NYSERDA, the State of New York, and the contractor make no representation that the use of any product, apparatus, process, method, or other information will not infringe privately owned rights and will assume no liability for any loss, injury, or damage resulting from, or occurring in connection with, the use of information contained, described, disclosed, or referred to in this report.

This report was prepared by BNL as an account of work sponsored by NYSERDA. Neither the United States Government nor any agency thereof, nor any of their employees, nor any of their contractors, subcontractors, or their employees, makes any warranty, express or implied, or assumes any legal liability or responsibility for the accuracy, completeness, or any third party's use or the results of such use of any information, apparatus, product, or process disclosed, or represents that its use would not infringe privately owned rights. Reference herein to any specific commercial product, process, or service by trade name, trademark, manufacturer, or otherwise, does not necessarily constitute or imply its endorsement, recommendation, or favoring by the United States Government or any agency thereof or its contractors or subcontractors. The views and opinions of authors expressed herein do not necessarily state or reflect those of the United States Government or any agency thereof. 


\section{Executive Summary}

This project, funded by New York State Energy Research and Development Agency (NYSERDA), investigated the potential for an oil-fired combined heat and power system (microCHP system) for potential use in residences that use oil to heat their homes. Obviously, this requires the power source to be one that uses heating oil (diesel). The work consisted of an experimental study using a diesel engine and an analytical study that examined potential energy savings and benefits of micro-CHP systems for 'typical' locations in New York State.

A search for a small diesel engine disclosed that no such engines were manufactured in the U.S. A single cylinder engine manufactured in Germany driving an electric generator was purchased for the experimental work. The engine was tested using on-road diesel fuel (15 ppm sulfur), and biodiesel blends. One of the main objectives was to demonstrate the possibility of operation in the so-called HCCI (Homogeneous Charge Compression Ignition) mode. The HCCI mode of operation of engines is being explored as a way to reduce the emission of smoke, and NOx significantly without exhaust treatment. This is being done primarily in the context of engines used in transportation applications. However, it is felt that in a micro-CHP application using a single cylinder engine, such an approach would confer those emission benefits and would be much easier to implement. This was demonstrated successfully by injecting the fuel into the engine air intake using a heated atomizer made by Econox Technologies LLC to promote significant vaporization before entering the cylinder. Efficiency and emission measurements were made under different electrical loads provided by two space heaters connected to the generator in normal and HCCI modes of operation.

The goals of the analytical work were to characterize, from the published literature, the prime-movers for micro-CHP applications, quantify parametrically the expected energy savings of using micro-CHP systems instead of the conventional heating system, and analyze system approaches for interaction with the local electric utility. The primary energy savings between the space heating provided by a conventional space heating system with all the required electrical energy supplied by the grid and the micro-CHP system supplemented when needed by a conventional space heating and the grid supplied electricity. were calculated for two locations namely Long Island and Albany.

The key results from the experimental work are summarized first and the results from the analytical work next.

Experimental results:

1. The engine could be operated successfully in the normal and HCCI modes using both diesel and biodiesel blends.

2. The smoke levels are lower with biodiesel than with diesel in both modes of operation.

3. The NOx levels are lower with the HCCI mode of operation than with the normal mode for both fuels.

4. The engine efficiency in these tests is lower in the HCCI mode of operation. However, the system parameters were not optimized for such operation within the scope of this project. However, for an engine designed with such operation in mind, the efficiency would possibly be not lower.

Analytical results:

1. The internal combustion engine (diesel engine in this case) is the only proven technology as a prime mover at present. However, as noted above, no U.S. engine is available at present. 
2. For both locations, the use of a micro-CHP system results in primary energy savings. This is true whether the CHP system is used only to supply domestic hot water or to supply both hot water and space heat and even for a low efficiency system especially for the latter case. The size of the thermal storage (as long as it above a certain minimum) did not affect this.

3. For example, for a $2 \mathrm{~kW}$ CHP electrical efficiency of $25 \%$, a typical house on Long Island will save about 30MBtu of energy per year for a combined space heat and domestic hot water system. This corresponds to annual energy savings of about 210 gallons oil equivalent per

4. The savings increased initially with the power capacity of the prime-mover, but flattened out at around $2 \mathrm{~kW}$ power output suggesting that a low power engine like the one tested is a good choice.

5. Reverse metering, that is, power returned to the electric grid when produced in excess of the local load, increased the primary energy savings significantly when using a $3 \mathrm{~kW}$ to $5 \mathrm{~kW}$ system with high fuel-to-electric efficiency.

6. In view of the current interest in plug-in electric or hybrid vehicles, the impact of night-time recharging on the micro-CHP operation was considered. Obviously, it will reduce the amount reverse metered and without reverse-metering, the primary energy savings were increased significantly.

7. The micro-CHP systems can contribute to the decrease of the carbon emissions of the local utility even with the use of diesel fuel and much more so with biodiesel use.

In terms of the future of oil-fired micro-CHP, the project has shown that an 'engine' of the right power can meet the hot water and space heat loads and offer savings in primary energy used thereby reducing the carbon emissions particularly if a biofuel is used. A small diesel engine can be operated in the HCCI mode with reductions in NOx and in smoke if biodiesel is used. However, there is work to be done to optimize this or similar engine for HCCI operation, demonstrate reliability of operation with less noise and minimal maintenance, integrate with the heating system and controls, and demonstrate performance in field tests. The economics of the system are not obvious at present and would have to be established based on market forces and conditions. 


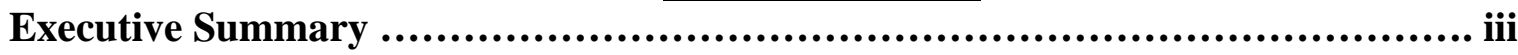

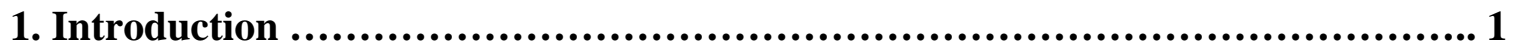

2. Brief Review of Work ............................................................... 2

3. Goals of the project …........................................................... 5

4. Details of Accomplishments in the Project ........................................ 5

4.1 Project work initiation ................................................... 5

4.1.2 Atomizer for operation in HCCI mode ................................. 7

4.2 Experimental set up ..................................................... 7

4.3 Experimental Results ............................................... 10

4.3.1 Test Procedure ....................................................... 12

4.3.2 Experimental Results ................................................ 12

4.3.2.1 Baseline Engine tests ............................................ 12

4.3.2.2 HCCI/mixed mode tests ............................................. 19

4.4 Combined Heat and Power (CHP) Operation ........................... 29

4.4.1 Experimental .......................................................... 29

4.4.2 Analytical work .................................................. 30

5. Discussion .................................................................... 32

6. Acknowledgements …........................................................ 33

7. References ..................................................................... 34

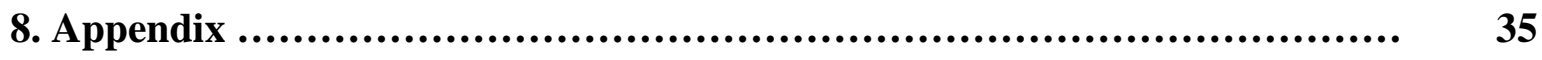

\section{List of Tables}

Table 1. Engine specifications [3] ......................................................

Table 2. Engine specifications [5] .................................................... 4

Table 3.Technical data of the IAV single-cylinder engine [6] ........................ 4

Table 4. Farymann Engine Specifications [http://www.farymann.de/]............... 6

Table 5. Performance of Heated Atomizer............................................. 8

Table 6. Sound emission from the engine............................................. 10 


\section{$\underline{\text { List of Figures }}$}

Figure 1. Econox Atomizer as delivered............................................. 8

Figure 2. The Farymann $18 \mathrm{~W}$ engine with the alternator............................. 9

Figure 3. Experimental set up for measurements..................................... 12

Figure 4. Fuel supplies to the engine and the atomizer................................. 13

Figure 5. System Electrical Efficiencies on different fuel blends...................... 14

Figure 5.2 Normalized electrical Efficiency as a function of blend fraction.............. 15

Figure 6. Carbon monoxide emission at 3\% $\mathrm{O} 2$ with the different fuel blends............ 15

Figure 6.2 Normalized Carbon monoxide emission at $3 \% \mathrm{O} 2$ as a function of blend

Fraction....................................................................... 16

Figure 7. Carbon monoxide emission as measured from ULSD as fuel................ 17

Figure 8. NOx emission from the different fuels......................................... 18

Figure 8.2 NOx emission from the different fuels...................................... 18

Figure 8.3 Variation of NOx levels with the blend fraction............................ 19

Figure 8.4 NOx per watt output..................................................... 19

Figure 9. Efficiency under HCCI (mixed mode) operation on ULSD fuel................ 21

Figure 10. Normalized efficiency as a function of atomizer flow....................... 22

Figure 11. CO emission under normal injection and mixed mode HCCI operation........ 22

Figure 12. CO as measured as a function of Atomizer Fraction at constant electrical

Load................................................................................... 23

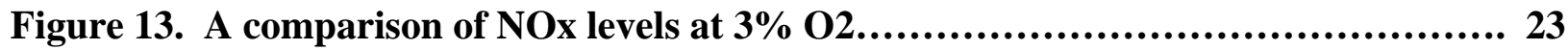

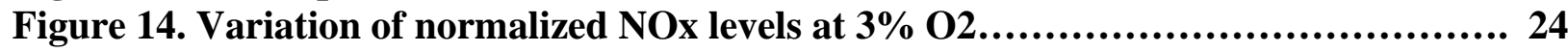

Figure 15. Efficiency under mixed-mode and engine operation with biodiesel.............. 26

Figure 16. Efficiency under mixed-mode (HCCI) operation with ULSD and Biodiesel... 26

Figure 17. Efficiency as a function of atomizer flow for the two fuels.................. 27

Figure 18. Normalized efficiency as a function of atomizer flow fraction................ 27

Figure 19. NOx at $3 \% \mathrm{O} 2$ with $\mathrm{B} 100$ in engine and in mixed-mode operation............. 28

Figure 20. NOx at $3 \% \mathrm{O} 2$ per Watt output for B100 in engine mode and mixed-mode... 28

Figure 21. A comparison of Bacharach Smoke Numbers in the Engine mode.............. 29

Figure 22. Filter loading in the Engine mode for ULSD and B100 fuels................. 29

Figure 23. A comparison of Bacharach Smoke Numbers............................... 30

Figure 24. Primary Energy Savings for Combined Space Heat and DHW Systems on

Long Island .............................................................................. 32

Figure 25. Primary energy savings for space-heating/DHW systems with reverse metering

on Long Island...................................................................33 


\section{Introduction}

A significant part of the residential buildings in the New York state use oil as the primary source of heat. There is increasing interest in biofuels, primarily biodiesel blends, because of the obvious problems with oil price volatility, with possible supply disruptions, Green House Gas (GHG) emissions etc. On the other hand, very few residences generate any part of their electrical power requirements. There is some penetration of solar PV, partly due to NYSERDA initiatives. Micro-CHP (micro Combined Heat \& Power) is the simultaneous production of heat and electricity in individual homes [http://www.microchap.info/]. Such systems are in an early stage of development and are primarily based on using natural gas as a fuel for the 'engine', which could be a fuel cell. This suggests that an opportunity exists for the development of micro-CHP systems based on using a liquid fuel in the 'engine'. This would promote the use of liquid fueled micro-CHP systems and the use of biofuels as well with the obvious benefits of reduction in the emission of pollutants, especially green house gases.

The heating oil used in residences is ASTM \#2 fuel oil (ASTM D 396). This is more or less similar to diesel fuel, the major difference being in the sulfur content, which can be up to about $0.2 \%$ (2,000 ppm) compared to $15 \mathrm{ppm}$ for on-road diesel fuel (ASTM D 975). Hence, an engine used in a micro-CHP application has to be able to use diesel-like fuel. This means one has to use a diesel engine, although engines such as a stirling engine, a steam engine or a microturbine could also be used. Of these, especially in the small size that was envisaged, the diesel engine is the one that seems to be most developed and available commercially for other applications.

In a micro-CHP application, broadly speaking, the engine operation is limited by the smaller of the electrical or thermal load at any time. This will limit the size of the engine to fairly small power outputs (hence the micro-CHP). As part of the project, an analytical effort was subcontracted to map the performance of potential engines in two typical New York locations, one representing Long Island and the other Albany. This work was performed by Dr. John Andrews (formerly of Brookhaven National Laboratory). This gave some pointers to the engine size and load for use in the testing, but the choice was constrained even more by what was available in the market in that size range.

There are several drawbacks to the operation of diesel engines in the residential context. Some of the significant ones are noise, Nitrogen oxides (NOx), carbon monoxide (CO), sulfur dioxide (SO2) and soot emissions. Noise could be reduced by appropriate use of a sound insulating installation. Control of $\mathrm{NOx}, \mathrm{CO}$ and soot emissions are more complicated. In Europe, and increasingly, in the U.S., diesel engines in transportation (trucks, cars) have exhaust 'treatment' to reduce these. NOx and CO are reduced by the use of so-called selective catalytic reduction, and soot is collected and intermittently burned in a particulate filter. While a similar approach could possibly work in the context of a micro-CHP installation, it would complicate the system and increase the cost significantly.

Another approach to reducing NOx and soot emissions is to modify the engine operation to what is termed Homogeneous Charge Compression Ignition or HCCI. Briefly put, this attempts to convert the distributed (spray-like) combustion in the engine with rich and lean zones of burning to the burning of a pre-mixed, lean, homogeneous combustion. The intent is to still keep the compression ignition of the conventional diesel engine and hence the name, HCCI. Because of the lean combustion, the peak temperatures will be lower giving lower NOx and soot production should be reduced because of the absence of fuel rich zones. While this is the ideal 
mode of operation desired, in practice, there are still many problems to be overcome especially in the context of transport applications where variable speed and load response is very important. It is also complicated by the presence of multiple cylinders. The operation in this mode should be somewhat less demanding in the stationary application where the load is a constant, as in the micro-CHP, which also would need only one cylinder because of the small power requirement. Of course, this technology is very much in the stage of research and development and hence questions related to long-term performance remain to be answered.

This report will detail the results obtained from the analytical work mentioned above and from the experimental work done in the laboratory on the performance of a commercial, single cylinder engine converted to operate in the HCCI mode. The conversion was facilitated by the use of a fuel atomizer with preheating, developed by the collaborator Econox Technologies, LLC.

\section{Brief Review of work done on HCCI diesel engines with external mixture formation}

There is a fairly extensive literature on HCCI engines as evidenced by the recent book 'HCCI and CAI engines for the automotive industry' [1]. This CAI in the title stands for Controlled Auto-Ignition and is primarily of interest in such ignition in gasoline engines. The idea is to use a lean mixture of gasoline and air, which will be heated by exhaust gas to a temperature sufficient for autoignition. This will give the benefits of operation in a 'diesel' mode with gasoline such as improved part load efficiency and low NOx owing to the lean mixture. In the diesel HCCI, the benefits from the homogeneous charge are expected to be lower NOx, and soot emissions compared to conventional diesel operation.

In conventional diesel engine, the injected fuel starts vaporizing in the cylinder and the vaporized mixture mixes with the 'right' amount of air and ignites. This 'pre-mixed flame' ignites the rest of the spray to burn as a diffusion flame around single and clusters of drops. It is this diffusion flame burning, which happens locally at almost adiabatic temperatures, that gives rise to the typical high levels of NOx emission. The fuel rich regions on the fuel side of the diffusion flame can lead to soot production, some of which is burned in the flame and the remaining is emitted with the exhaust gas. The idea of the HCCI is to eliminate, in principle, the diffusion flame by premixing all the fuel with more or less all the air. For this to be possible, three things are necessary to be achieved in the short time available in the engine operation [1, p247]:

1. A homogeneous mixture has to be created.

2. The mixture has to be ignited in a controlled manner.

3. The combustion has to be controlled so that the engine performance can be optimized.

Mixture creation requires that the fuel be a very fine mist or a vapor, and the mixing be done quickly. Ignition requires the right temperature and pressure conditions if auto ignition has to be relied upon. The discussion in Zhao [1] examines various approaches that have been tried. Fuel injection in the intake port is considered the most straightforward method considering the time needed for mixture formation. As this was the method adopted here, other approaches will not be reviewed here.

A more recent review is by Yao et al [2]. They list some of the challenges of HCCI operation as, difficulty of control of start of ignition and in cold start, high levels of noise, unburned hydrocarbons and carbon monoxide emissions, operating range limitations, and effective mixture preparation. These challenges are discussed in the context of total HCCI operation. As will be seen later, we did not achieve complete HCCI operation and it would seem 
that there is a benefit to operation in a 'mixed mode', where some of the fuel is injected in the conventional way into the cylinder and the remaining fuel is injected into the intake, especially in the present application. We will discuss the few publications that are most immediately relevant to the present project. Midlam-Mohler et al [3] review the problems with internal mixture formation using the engine injector. The traditional external mixture formation with the heating of the intake air to 100 to $200^{\circ} \mathrm{C}$ to aid in the evaporation of the fuel cause problems of preignition and knocking. So, they have tested a single cylinder engine with fuel injection in to the intake port, using a proprietary atomizer. The drop size from the atomizer is said to be very fine 'so that a 'gas-like' aerosol' is formed and wall wetting is not a serious problem. The atomizer power consumption was rather high at 600 watts, but they indicate that improvements to the atomizer are possible that will reduce this significantly. They tested HCCI operation in the engine with the following characteristics given in Table 1 below:

Table 1. Engine specifications [3]

\begin{tabular}{|l|l|}
\hline Type & OM-611 \\
\hline Cylinders & 1 \\
\hline Valves per cylinder & 4 \\
\hline Displacement & $537.7 \mathrm{~cm}^{3}$ \\
\hline Bore & $88.0 \mathrm{~mm}$ \\
\hline Stroke & $88.4 \mathrm{~mm}$ \\
\hline Connecting Rod Length & $149 \mathrm{~mm}$ \\
\hline Geometric CR & $18: 1$ \\
\hline Nozzle type (DI) & 6 holes \\
\hline Injection system (DI) & $\begin{array}{l}\text { Common-rail } \\
\mathrm{P}_{\mathrm{R}}=1600 \text { bar }\end{array}$ \\
\hline
\end{tabular}

Both intake pressure boost and EGR were used unlike in our tests. The results from this work will be referred to later in the results section. Canova et al [4] show some of the same results as in the previous reference and also have some results on a four-cylinder engine.

Ganesh et al [5] present their work with a modified, single cylinder, air-cooled diesel engine in HCCI operation using external mixture formation. The engine specifications are given in table 2 below. This engine's power output is similar to the engine tested in this project, but at half the speed. The homogeneous mixture was formed externally by vaporizing the diesel fuel in a vaporizer at $90^{\circ} \mathrm{C}$ and injecting it into the intake manifold where it is mixed with the air. They warm up the engine in the engine mode when all the fuel is delivered from the engine injector and then switch to operation in the HCCI mode, when all the fuel is introduced into the intake. Their results will be discussed below. However, they say that they had to include EGR to reduce smoke and they could operate in the HCCI mode up to about $75 \%$ of the maximum load. 
Table 2. Engine specifications [5]

\begin{tabular}{|l|l|}
\hline General Details & $\begin{array}{l}\text { Single cylinder, four stroke, compression ignition, Constant } \\
\text { speed, vertical, air cooled, direct injection }\end{array}$ \\
\hline Bore & $87.5 \mathrm{~mm}$ \\
\hline Stroke & $110 \mathrm{~mm}$ \\
\hline Swept Volume & $662 \mathrm{~cm}^{3}$ \\
\hline Injection Timing & $23 \mathrm{deg} \mathrm{bTDC}$ \\
\hline Compression Ratio & $17.5: 1$ \\
\hline Rated output & $4.4 \mathrm{~kW}$ at $1500 \mathrm{rpm}$ \\
\hline Rated Speed & $1500 \mathrm{rpm}$ \\
\hline Injection pressure & $200 \mathrm{bar}$ \\
\hline
\end{tabular}

A group at OWI in Germany has modified their 'cool flame' vaporizer to produce external mixture formation and tested in a single cylinder diesel engine [6]. A cool flame is the product of a limited exothermic reaction that is associated with a partial conversion of the fuel. The heat released in the reaction can be used to vaporize liquid fuel. So, it is conceivable that by partially oxidizing some of the fuel in a cool flame, the rest of the fuel can be vaporized without external heat addition. Of course, to initiate the cool flame reactions, the fuel-air mixture has to be heated to a fairly high temperature $\left(\sim 400^{\circ} \mathrm{C}\right)$. The hot products from the cool flame are mixed with the rest of the fuel to vaporize it and the rest of the charge air. They tested the concept in a research engine with the following features given in table 3:

Table 3.Technical data of the IAV single-cylinder engine [6]

\begin{tabular}{|l|l|}
\hline Displacement & $537 \mathrm{~cm} 3$ \\
\hline Bore & $88 \mathrm{~mm}$ \\
\hline Geom. compression ratio & Adjustable with piston relief \\
\hline Number of valves & 4 \\
\hline Combustion chamber design conventional & Conventional \\
\hline Cylinder head & $\begin{array}{l}\text { Two accesses for indication and optical } \\
\text { sensors }\end{array}$ \\
\hline Compensation of inertia forces & 1. and 2. order \\
\hline Max. cylinder pressure & 220 bar \\
\hline Max. engine speed & 5000 rpm \\
\hline Injection system & $\begin{array}{l}\text { Close-to-production common rail } \\
\text { system }\end{array}$ \\
\hline
\end{tabular}

They had to reduce the compression ratio to 14 and use a high EGR of the order of $60 \%$ or reduce the gas mixture temperature to control the start of ignition. They do indicate a lowering of the NOx emission, but higher unburned hydrocarbon, unburned fuel as well as CO emissions. The system would be inherently much more complicated with the cool flame vaporizer, EGR etc. 


\section{Goals of the project}

The goals of the project were as below:

1. Analyze the range of liquid-fueled micro-CHP options available for residential applications and establish the optimum parameters for each prime mover.

2. Demonstrate, in the laboratory, the operation of an innovative diesel engine as part of a microCHP system and also to explore the feasibility of integrating a novel thermal atomization scheme.

3. Scope the use of alternative, renewable biofuels in the engine.

\section{Details of Accomplishments in the Project}

\subsection{Project work initiation}

The analysis of micro_CHP options was conducted through a research services subcontract with Dr. John Andrews. Relevant results from the analysis will be incorporated in the body of the report and Dr. Andrews's complete report will be included in an appendix.

\subsubsection{Choice of Engine}

A search of diesel engines of suitable capacity ( 1 to $5 \mathrm{kw}$ range in power) available on the market was conducted. An engine that had been, presumably, 'converted' to HCCI operation by D-Star Engineering Corporation [7] was originally thought to be available and contacts were pursued with negotiations on an NDA (Non-Disclosure Agreement). But, this could not be accomplished and so this attempt at collaboration was dropped. On the recommendation of the program manager, Yanmar Engines, who had a small gas fired engine operating in the CHP mode, was contacted. Yanmar also had a micro-CHP project with Newcastle University in England operating on biodiesel [8] and the faculty there was also contacted. These contacts did not succeed either, for lack of interest from the manufacturer, it seemed. As a result of the search, a commercial engine-generator system used in marine environments was identified as reasonably suitable for the research.

A review of the literature suggests some requirements for an engine to be used in the HCCI mode. The homogeneous charge has to be generated by mixing the fuel and the air before start of combustion. Several approaches have been tried to modify the basic injector to introduce fuel early enough for mixing to occur in the cylinder. Chamber shape could also be a factor in the mixing. The auto ignition process is determined by the temperature and pressure of the homogeneous charge and has to be controlled for proper operation of the engine. This becomes especially difficult in mobile applications with varying speed and load as this has to be varied in response to those parameters. Varying EGR, varying valve actuation, variable compression ratio etc. are some of the techniques suggested and tried. Mixed mode operation could be another approach and was found to have some merits from the results of this project. Some of these may also be needed to avoid knock in the engine at high loads depending on the compression ratio and often, people revert to normal diesel operation at high loads. Knock at high loads can also limit the usable compression ratio of the engine if it is not to be varied. Also, the engine noise and stresses on the structures can exceed those for normal diesel operation at high loads. In the present project, we proposed to use external formation of the homogeneous mixture by injecting the fuel in to the intake and did not plan to operate at the highest loads that the engine was capable of. Also, the engine drives an electric generator and hence maintains a constant speed with load. On the other hand, no control could be exercised over the start of ignition and in any case as will be seen below, we could not operate in total HCCI mode. 
The engine used in the tests is a Farymann Diesel Model $18 \mathrm{~W}$ with the specifications given below in Table 4. It is a four-stroke, water-cooled engine made in Germany and in the version used it is coupled to an Italian make alternator Mecc Alte S $16 \mathrm{~W}$ by a supplier in the U.S. It has an electrical starter. The engine is governed to maintain a constant speed. It has about half the displacement of the engines in the studies mentioned above, but the governed rotational speed, at which the testing was done, is higher than in the studies above. Also, the compression ratio is higher than one would probably want for satisfactory HCCI operation at high loads. The alternator has two load circuits and two similar room space heaters (Honeywell) were connected to these to create a balanced load on the alternator and hence the engine. The engine can generate about $5 \mathrm{~kW}$ and the alternator is capable of about $5 \mathrm{~kW}$ also. However, the maximum load that can be generated by the space heaters together is about $3.3 \mathrm{~kW}$. Hence, the engine was tested at a maximum of about $65-70$ percent of its rated capacity.

\section{Table 4. Farymann Engine Specifications [http://www.farymann.de/]}

\section{Technische Daten / Technical data}

Modell / engine type

$18 \mathrm{~W}$

Bauweise / configuration

stehend / vertica

Zylinder / cylinders

1

Kühlung / cooling

Wasser / water

Max. Leistung (bei $3600 \mathrm{~min}^{-1}$ )/ max. output (at $3600 \mathrm{rpm}$ )

IFN-ISO

$\mathrm{kW}(\mathrm{HP})$

$5.2(7.1)$

ICFN-ISO

$\mathrm{kW}(\mathrm{HP})$

$4.7(6.4)$

Max. Drehzahl/ max. speed

$\min ^{-1}$

3600

Max. Drehmoment / max. torque

$\mathrm{Nm}\left(\mathrm{min}^{-1}\right)$

$15.3(2500)$

Bohrung / bore

$\mathrm{mm}$

82

Hub / stroke

$\mathrm{mm}$

55

Hubraum / displacement

$\mathrm{cm}^{3}$

290

Mittlere Kolbengeschwindigkeit / mean piston speed

$\mathrm{m} / \mathrm{s}$

$6.6 / 3600$

Verdichtungsverhältnis / compression ratio

$1: 20$

Schmierölmenge / oil sump capacity

Schmierölverbrauch / oil consumption

Max. Neigungswinkel / max. inclination

Trockengewicht / dry weight

Kühlwasserbedarf bei direkter Kühlung

Cooling water requirement

$\begin{array}{ll}\text { I } & 1: 20 \\ \text { g/kWh } & 1 \\ \text { permanent } & 1 \\ \text { kg } & 15^{\circ} \\ \mathrm{l} / \mathrm{min} & 39 \\ & 7-8\end{array}$



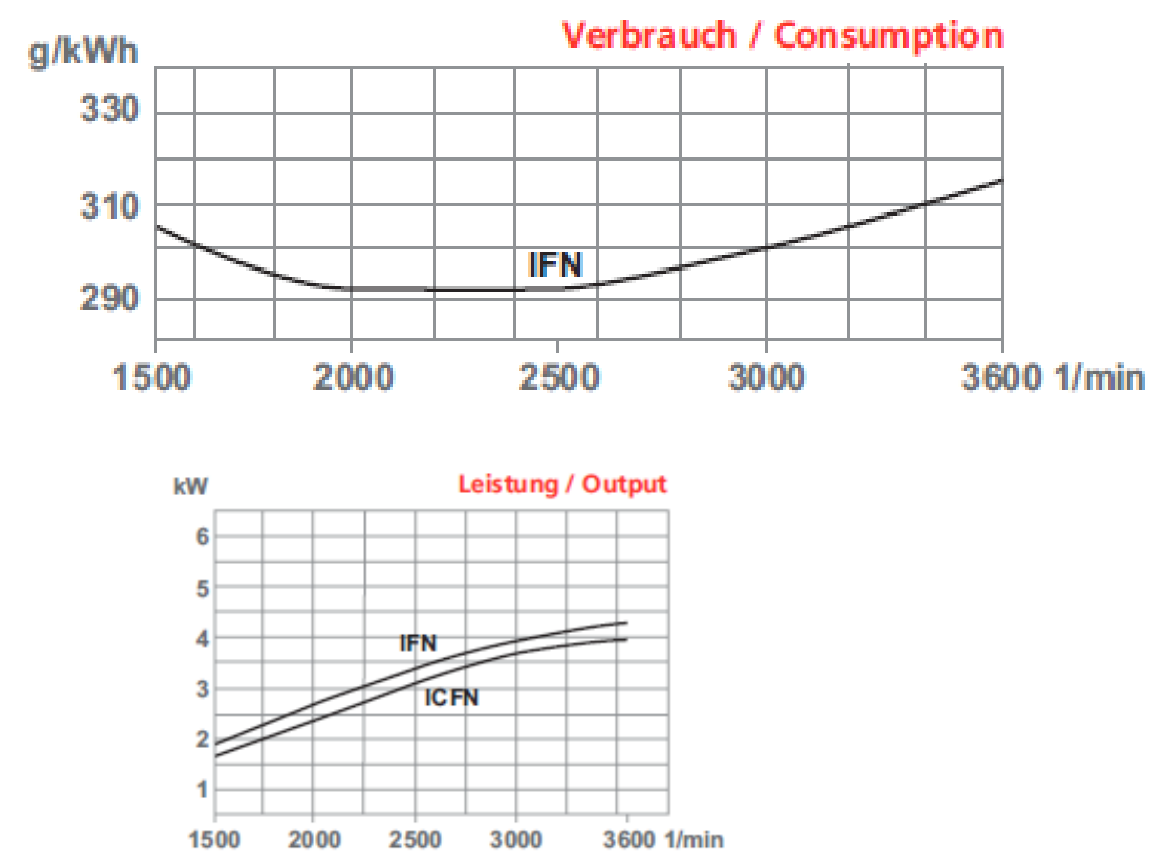

\subsubsection{Atomizer for operation in HCCI mode}

The literature review suggests that different schemes have been used for HCCI operation including modification of the engine fuel injection process, injection of aerosolized fuel in the intake and aspiration of vaporized fuel into the intake. In this project, a heated pressure atomizing nozzle made by the collaborator Econox Technologies LLC was used to inject the fuel into the intake of the engine. The concept was that the fuel mean drop sizes will drop significantly with heated fuel and therefore the fuel will evaporate quickly enough in the engine cylinder to provide the 'homogeneous' charge required for HCCI operation. Personnel from the company visited BNL to look at the engine set-up and delivered an atomizer with the built in heater and a control. The atomizer is shown in figure 1 below as delivered. It is built around a standard residential oil burner nozzle and fuel line enclosed in a ceramic heater. There is a thermocouple also embedded that can be used to set the required temperature. The nozzle can be easily replaced to choose the required size and the heater uses only about 60 watts. The 'funnel' with the flange was made to fit the mounting flange on the engine, which normally connects to the dry air filter on the intake that comes with the engine. As will be described later, this mounting and the air filter were not used during the testing of the engine. 


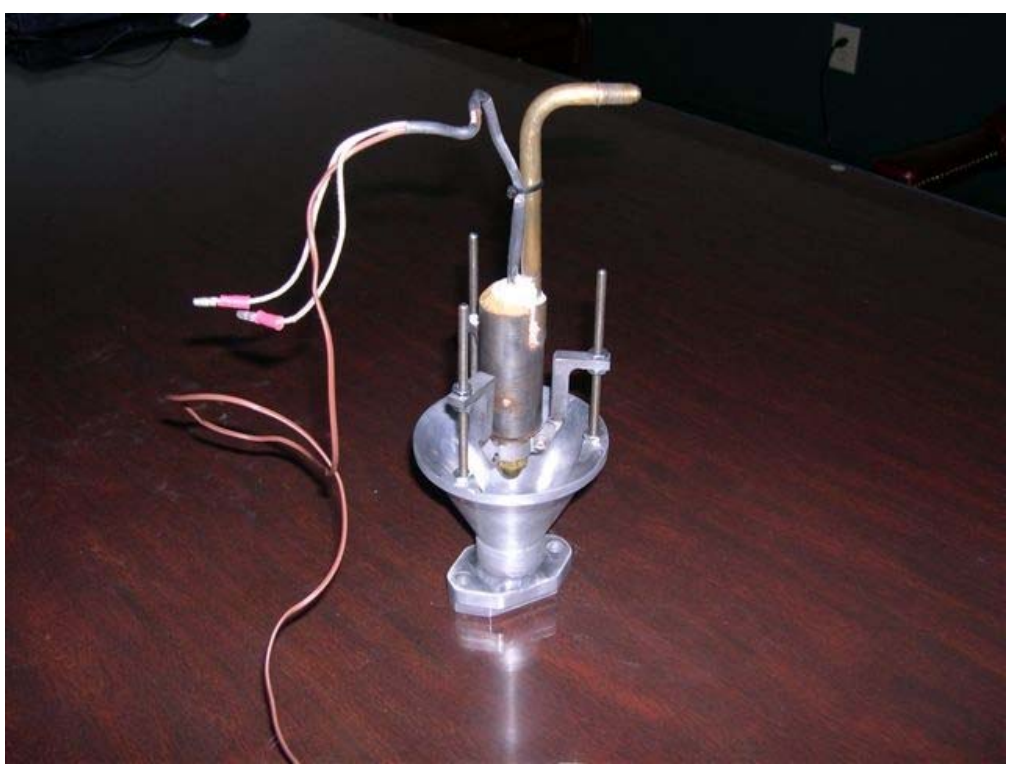

Figure 1. Econox Atomizer as delivered

The atomizer performance at different pressures and temperatures of the nozzle had been measured using the Malvern Spray Analyzer [9]. The Table 5 below gives a representative sample of the data. It can be seen that the flow rate goes down by about 20 percent in heating from room temperature to $250^{\circ} \mathrm{F}$, while more importantly, the mean drop size drops significantly especially at the lower pressures. This means one can use a relatively large nozzle at a low pressure thus minimizing problems of nozzle clogging and obtain the low drop sizes required in this application by heating to a high temperature. As only the fuel in the nozzle is heated, the power requirements will not be high compared to heating the charge air. If the charge air is heated with Exhaust Gas Recirculation (EGR), problems of soot formation and reduction in power due to lower mass of charge air arise.

Table 5. Performance of Heated Atomizer.

\begin{tabular}{|c|c|c|c|c|c|c|c|c|c|}
\hline \multicolumn{8}{|c|}{ Delavan 0.75 70 A } \\
\hline \multirow{2}{*}{ PSI } & $\mathbf{7 0}$ & $\mathbf{1 4 0}$ & $\mathbf{1 5 0}$ & $\mathbf{1 6 0}$ & $\mathbf{1 8 0}$ & $\mathbf{1 9 0}$ & $\mathbf{2 0 0}$ & $\mathbf{2 2 0}$ & $\mathbf{2 5 0}$ \\
\hline \multirow{2}{*}{$\mathbf{4 0}$} & 0.51 & & 0.46 & & & & & & 0.41 \\
\cline { 2 - 11 } & 54 & & 41 & & & & & & 30 \\
\hline \multirow{2}{*}{$\mathbf{5 0}$} & 0.56 & 0.51 & 0.50 & 0.49 & 0.48 & & 0.48 & 0.47 & 0.45 \\
\cline { 2 - 11 } & 46 & 37 & 33 & 36 & 34 & & 32 & 31 & 26 \\
\hline \multirow{2}{*}{$\mathbf{6 0}$} & 0.61 & 0.53 & 0.54 & 0.54 & 0.50 & & 0.50 & 0.50 & 0.49 \\
\cline { 2 - 11 } & 40 & 33 & 30 & 32 & 30 & & 29 & 28 & 25 \\
\hline \multirow{2}{*}{$\mathbf{7 0}$} & & 0.58 & 0.58 & 0.56 & 0.56 & & 0.54 & 0.53 & 0.52 \\
\cline { 2 - 11 } & & 31 & 28 & 31 & 28 & & 28 & 26 & 24 \\
\hline \multirow{2}{*}{$\mathbf{8 0}$} & & 0.62 & 0.61 & 0.58 & 0.58 & & 0.57 & 0.56 & 0.55 \\
\cline { 2 - 11 } & & 29 & 26 & 28 & 26 & & 26 & 25 & 23 \\
\hline \multirow{2}{*}{$\mathbf{9 0}$} & & 0.65 & 0.64 & 0.63 & 0.61 & & 0.61 & 0.57 & 0.58 \\
\cline { 2 - 10 } & & 27 & 25 & 26 & 25 & & 25 & 24 & 22 \\
\hline $\mathbf{1 0 0}$ & & 0.66 & 0.67 & 0.64 & 0.65 & & 0.64 & 0.62 & 0.61 \\
\hline
\end{tabular}




\subsection{Experimental set up}

Figure 2 below is a photograph of the engine-alternator. As delivered, the cooling water from the engine was intended to be discharged into the engine exhaust. The exhaust then can be discharged under water, a convenience in marine applications as intended. However, exhaust gas measurements would not be possible and hence it was replaced with a dry exhaust. The cooling water supply in our experiments was contained in a large plastic container and the water was returned to the same container after it exited the engine cooling jacket. The engine has a crankshaft driven fuel pump that compresses the fuel to be fed to the injector and the injection pressure is given as 2900 psi. Excess fuel from the injector is returned to the fuel tank. The engine speed is maintained constant by a mechanical governor. The engine has two valves and has air and fuel filters.

For HCCI operation, the fuel was introduced in the intake using the Econox atomizer. With the atomizer injection, the fuel will consist of fine drops and hence could not be allowed to impact the air filter. Therefore, all the experiments including the baseline tests were conducted without the air filter housing in place. Clearly, in practical implementation, one would inject between the air filter and the intake valve.

Fuel was supplied from a small plastic container that was seated on a scale for flow measurements. The fuel to the engine injector is supplied by the fuel pump as normally. The fuel to the atomizer used for the HCCI operation mode, which will be described in more detail later, was supplied by a small pump from another plastic container on a scale. The pump pressure was varied to vary the fuel flow in the atomizer. The space heaters were connected to the two circuits in the alternator as indicated above (see figure 3 below) through two power meters so that the electrical output could be measured. The space heaters have three operating settings at roughly a third, two-thirds and at full capacity.

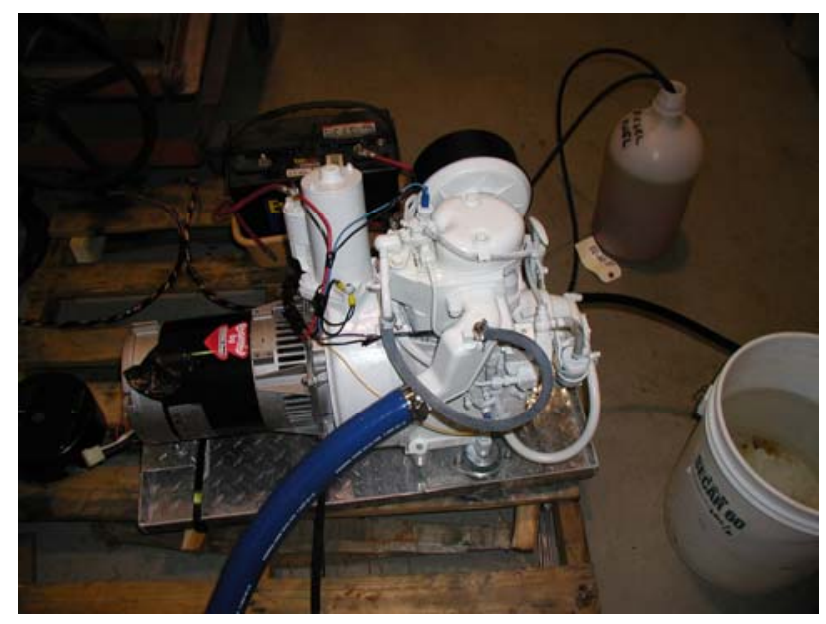

Figure 2. The Farymann $18 \mathrm{~W}$ engine with the alternator 
The exhaust gas composition was measured using a portable analyzer, Wohler A500, which is used in the laboratory for stack measurements. It uses electrochemical cells for measuring O2, CO, and NOx. A hole was drilled in the exhaust pipe, which was vented outside the building, and the Wohler probe inserted into it for measurements.

The engine-generator does not have a muffler on the exhaust or a sound proof housing. Consequently, safe operation required measurement of the sound levels to determine adequate hearing protection. The results of the noise measurements conducted by an Industrial Hygienist are given in the Table 6 below [10]. The allowable noise level in a work location is $85 \mathrm{dbA}$ and this is clearly exceeded by levels of about $100 \mathrm{dbA}$ even five feet from the engine. Hence, the operating personnel had to wear two levels of ear protection, an earplug and an earmuff. This is obviously unacceptable in a residential context and hence would need appropriate measures of sound proofing to reduce the ambient levels in the engine installation.

Table 6. Sound emission from the engine

\begin{tabular}{|c|c|}
\hline \multicolumn{2}{|c|}{ Faryman $18 \mathrm{~W}$ Diesel Engine } \\
\hline Location & dBA \\
\hline Start up of engine ( $1 \mathrm{ft}$ away) & 100.8 \\
\hline Above engine ( $\sim 3 \mathrm{ft}$ away) & 102.4 \\
\hline $3 f t$ away from engine & 102.2 \\
\hline $5 \mathrm{ft}$ away from engine & 99.9 \\
\hline At blue door (labeled - 4) & 99.1 \\
\hline Main entrance (1st door into bldg) & 94 \\
\hline $\begin{array}{l}\text { Hallway (outside of room w/engine and } \\
\text { next to empty room) }\end{array}$ & 90.2 \\
\hline Next room over (middle of room) & 85 \\
\hline $\begin{array}{l}\text { Back door room w/ engine ( } 2 \mathrm{ft} \text { from } \\
\text { engine, door was open and standing } \\
\text { outside) }\end{array}$ & 103 \\
\hline
\end{tabular}

\section{$\underline{4.3 \text { Experimental Results }}$}

\subsubsection{Test Procedure}

The experimental set up is shown in the photograph, figure 3 below. The engine exhaust had to be vented through the window to the outside. A small hole drilled into the exhaust pipe provides access for the probe of the Wohler instrument. The white plastic tank in the foreground contains the water used for engine cooling. The water temperature increases gradually in the 
course of the testing, as the water is returned after cooling the engine, but the volume in the tank and the losses are sufficient to keep the temperature rise well within the operating limits specified by the manufacturer of the engine. The fuel for the engine injector and the fuel for the atomizer in the HCCI mode of operation, are supplied from two plastic bottles placed on scales (Figure 4). The fuel flows are measured by timing the difference in masses in the course of testing. The injector fuel supply is of course drawn by the fuel pump and supplied to the injector under pressure of 2,900 psi according to the manufacturer. The fuel for the atomizer nozzle is supplied by the small pump (visible in the farther tray in figure 4), with a metering valve and a pressure gauge on the delivery side. The pressure and the metering valve opening are varied during the experiments to give different rates of fuel flow through the atomizer. The two space heaters (black) are seen on the left and are connected to the alternator through two power meters (on the ground in figure 3). The atomizer, as described above, has an electrical heater for heating the oil. The controller that had been sent by Econox with the atomizer was found to be faulty and had led to burning out of the heater in bench tests. When it was finally repaired, it was found that the temperature overshoot above the set point was too large and hence it was replaced with a Cole-Palmer controller that was borrowed from another project (on the table on the left in figure 3 ) and offered a more precise control of the set point temperature. A thermocouple on the nozzle body is connected to the controller and provides the input. In principle, the experiments could be conducted at different temperature settings for the nozzle. However, it was decided that a sufficiently high constant temperature of $300^{\circ} \mathrm{F}$ would be maintained for all the experiments.

The tests were conducted by starting the engine and warming up on diesel fuel (on- road ULSD was used) on no load. Then, the electrical load was increased in steps. Measurements were taken of the exhaust gas composition and of the fuel flow rate at each load under steady state conditions. When HCCI operation was being tested, typically the engine was warmed up to run on idle (no load) and fuel was injected into the intake while increasing the load on the engine. Exhaust gas composition and both fuel flow rates were measured under steady operation. Biodiesel was also tested in the engine and in HCCI operation. We do not have independent control of engine injection flow, but the governor reduces that flow as the HCCI flow is increased at any load in order to keep the engine-alternator speed constant.

As mentioned above, the noise in the room required training for the researchers operating the engine and also two levels of ear protection. There is also a Carbon monoxide detector in the room to warn the occupants through an audible alarm if the level exceeds safe limits in the room. 


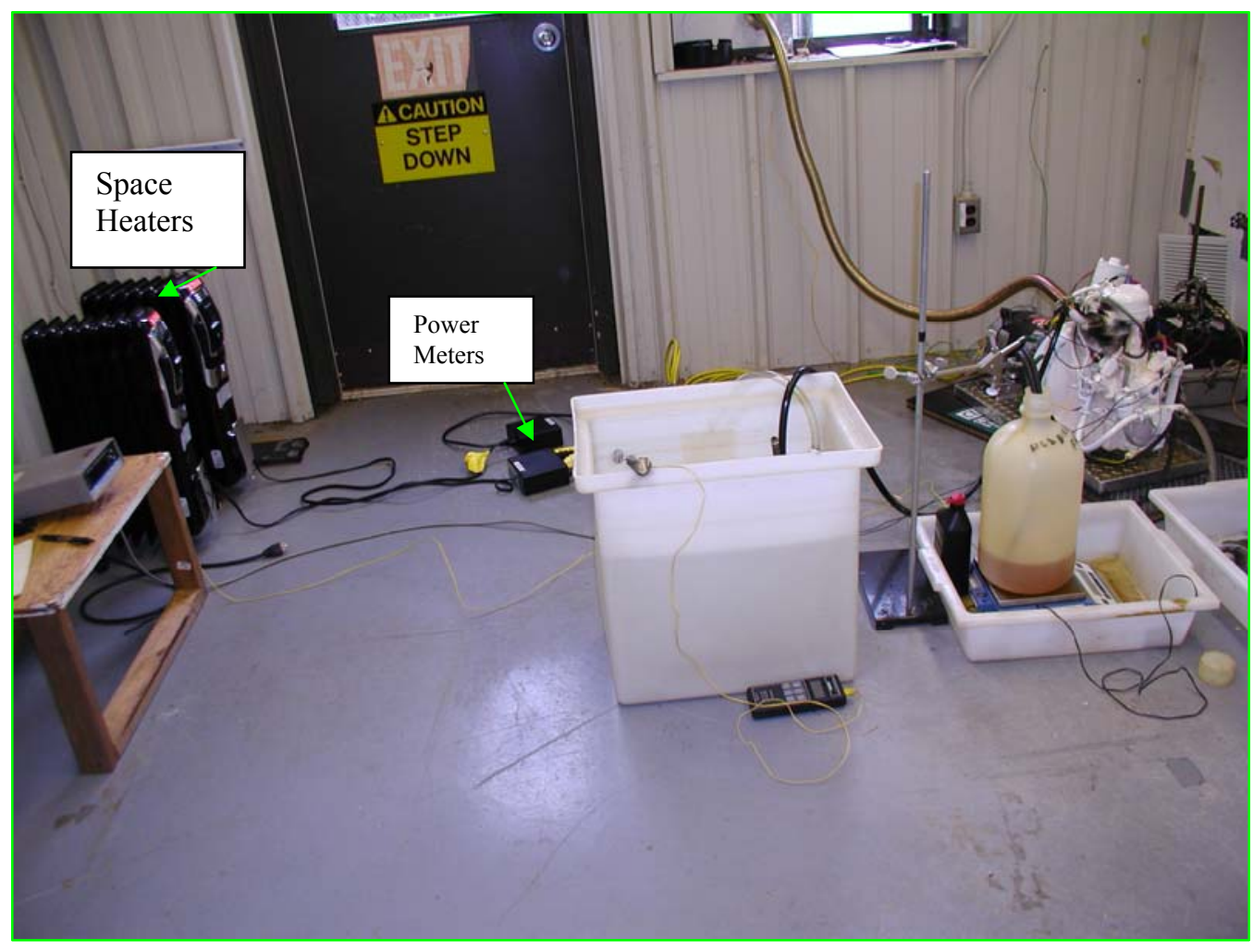

Figure 3. Experimental set up for measurements 


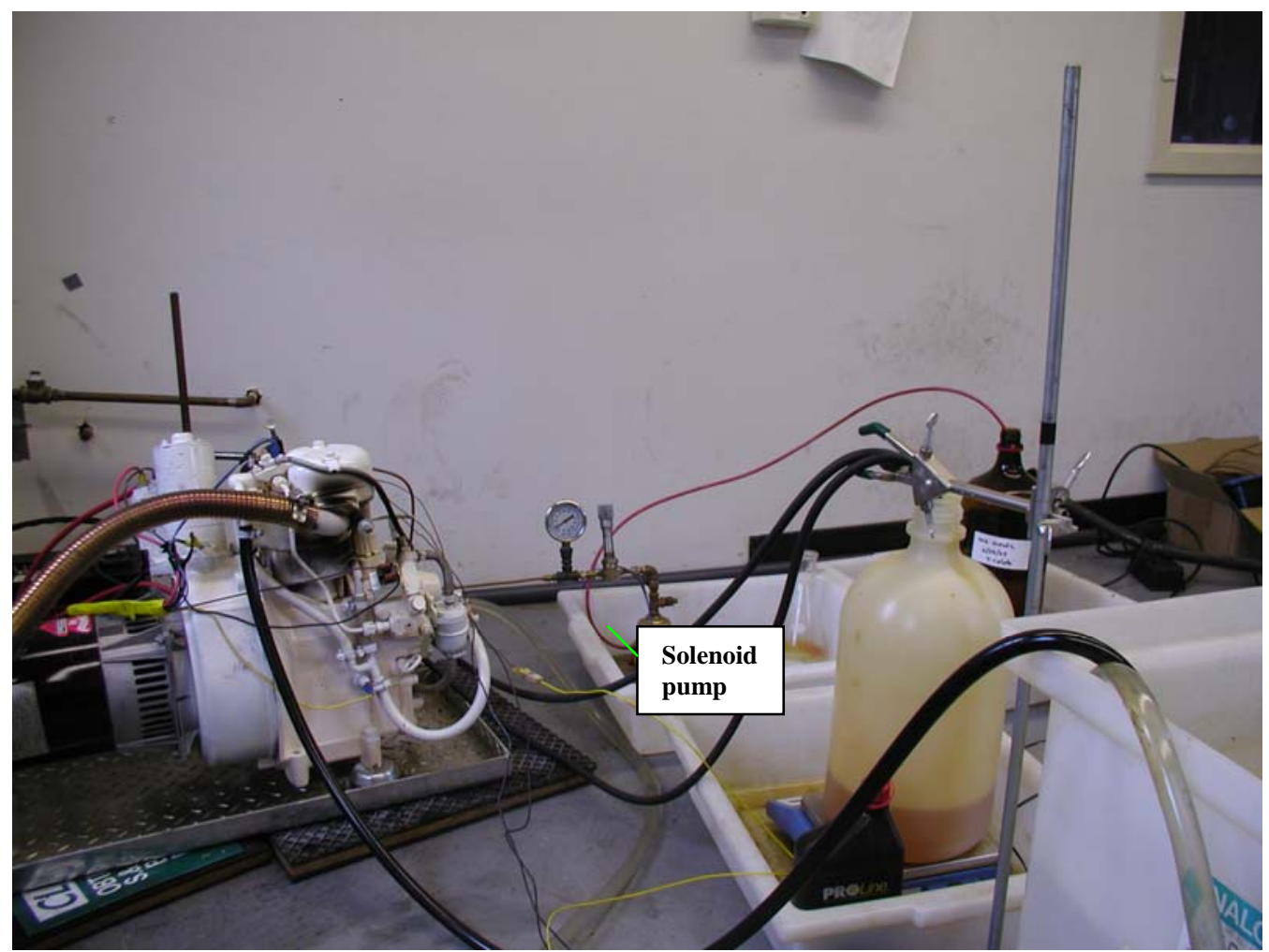

Figure 4. Fuel supplies to the engine and the atomizer.

\subsubsection{Experimental Results}

The performance of the baseline engine was measured at varying loads using the ULS diesel and blends of the ULSD with biodiesel. Subsequently, the engine performance under HCCI mode was tested on ULSD and on biodiesel. For the biodiesel tests, the injector was operated on ULSD to provide consistent ignition. The results from the baseline engine tests will be presented first and subsequently those for the HCCI mode will be described.

\subsubsection{Baseline Engine tests}

Figure 5 gives the electrical efficiency of the system, defined as the ratio of the electrical load to the fuel energy input. This of course includes the generator efficiency at the different loads. The efficiency does increase with the load, a good part of which could be due to the change in generator efficiency. The manufacturer's specification (see above) gives an efficiency of about $25 \%$ for the engine at $3600 \mathrm{rpm}$ and it does not change significantly at $1500 \mathrm{rpm}$ (and at less than half the maximum power). The data shows some scatter, but it seems reasonable to suggest that the efficiency does not change when the fuel is a biodiesel blend or pure biodiesel. Of course, these are short-term laboratory tests and as the biodiesel has about a $10 \%$ lower heating value, the flow rate through the injector is higher for the same power output, and the injection system seems able to handle it in the range of loads tested here.

The solid line in Figure 5 is the least squares fit of the data and is given by:

$$
\eta=0.2125+0.01(\mathrm{P} / 3500)-0.00439(\mathrm{P} / 3500)^{-3.26}
$$


where $\mathrm{P}$ is electrical load in Watts and $\eta$ is the calculated efficiency. This equation gives the dependence of efficiency on the electrical load and hence the engine power output. To isolate the effect of blend fraction on the efficiency, the measured efficiency was divided by $\eta$ and plotted against the blend fraction. The result is plotted in Figure 5.2. As can be seen, and as mentioned earlier, the normalized efficiency is virtually independent of the blend fraction.

Figure 6 shows the $\mathrm{CO}$ emission corrected for dilution and presented at 3\% O2. Cutting through the scatter, at first glance, it does seem that the emission levels are similar for all the fuels and increase with reduction in the load as expected. To examine this more closely, a least squares fit of the data as a function of the electrical load was determined. It is given by:

$\mathrm{CO \eta}=514+4421 \exp [-(\mathrm{P}+298.6) / 891]$

This is plotted as a solid line in Figure 6. The measured values of $\mathrm{CO}$ at $3 \% \mathrm{O} 2$ in this figure were then divided by equation (2) above to find any influence of the blend fraction on CO levels. This is shown in Figure 6.2. The data seem to suggest that while the $\mathrm{CO}$ emission levels are similar for "pure" fuels, the CO levels for the blended fuel are slightly higher. The solid blue line in Figure 6.2 is given by:

Normalized $\mathrm{CO}$ at $3 \% \mathrm{O} 2=1.21-1.28(\mathrm{f}-0.5039)^{2}$

\section{Biodiesel Blend Efficiency}

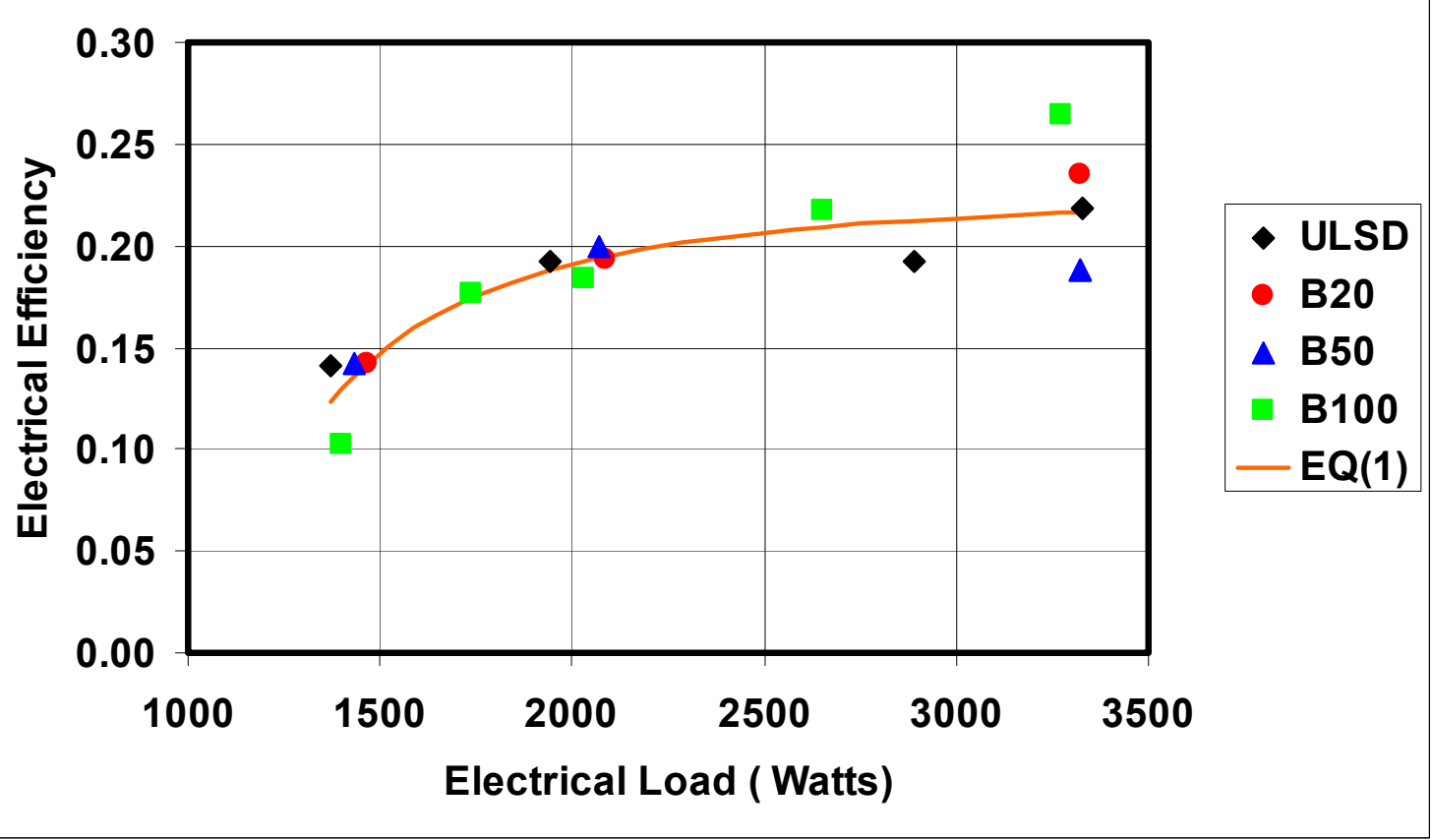

Figure 5. System Electrical Efficiencies on different fuel blends 


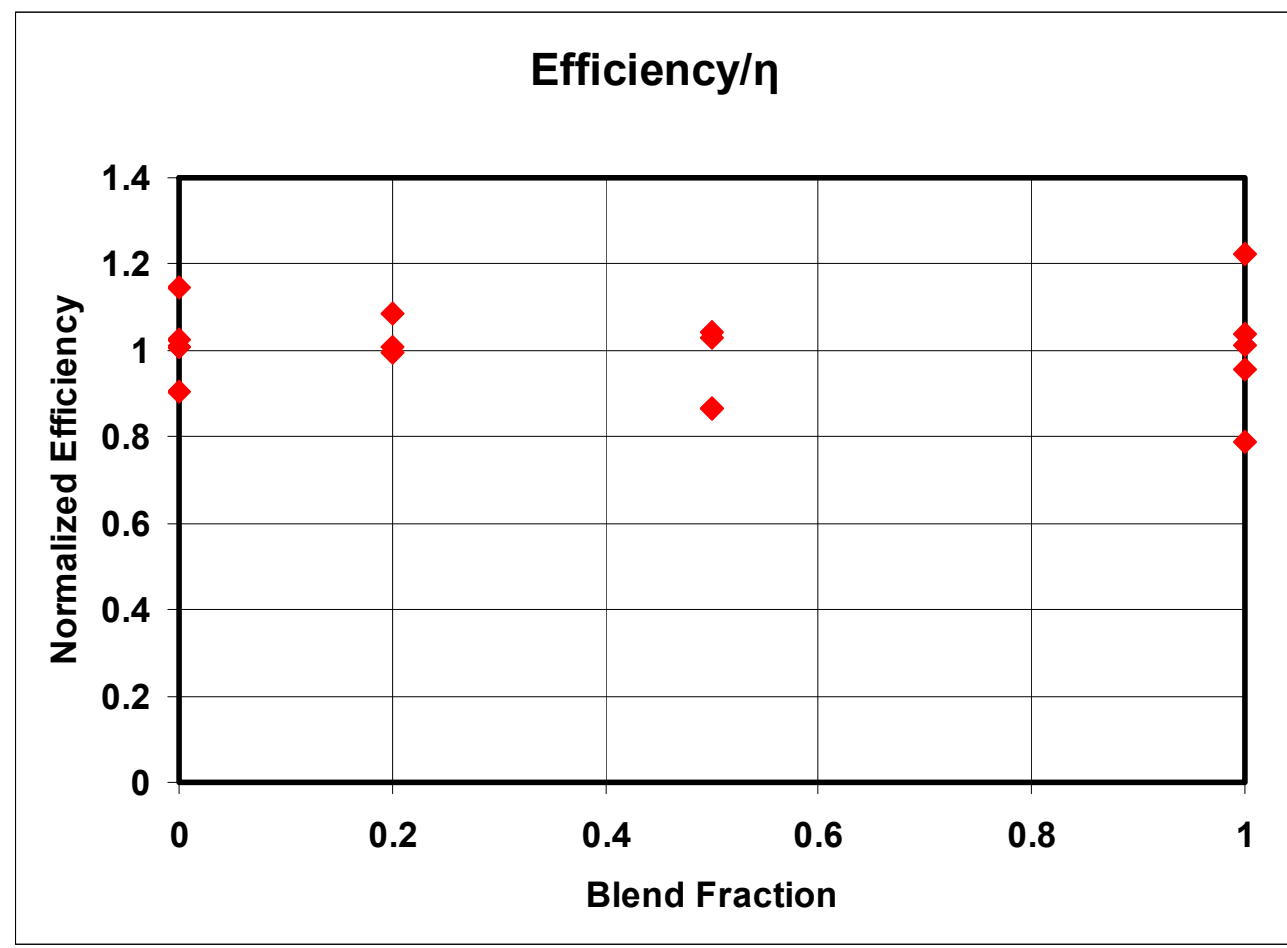

Figure 5.2 Normalized electrical Efficiency as a function of blend fraction.

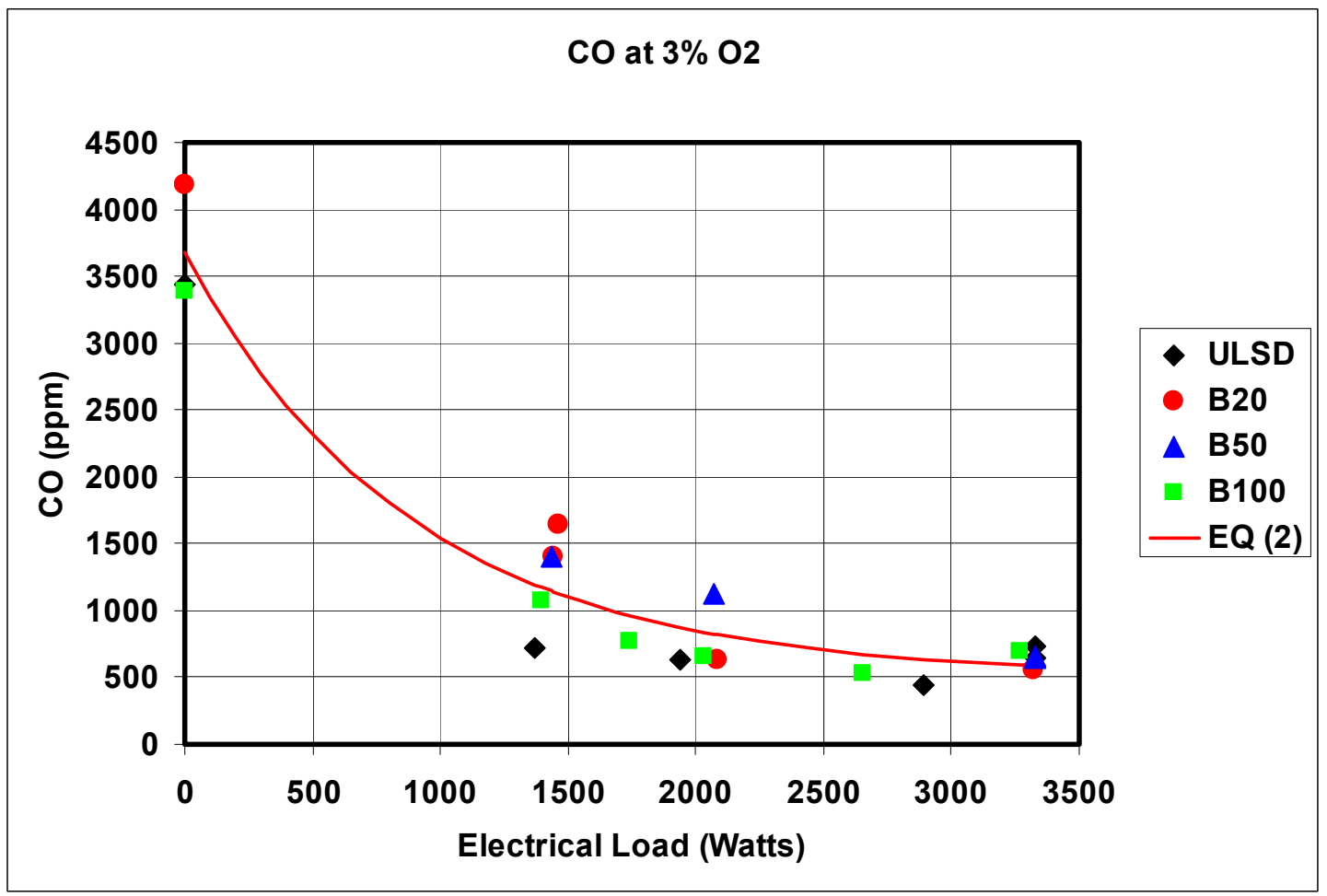

Figure 6. Carbon monoxide emission at $3 \% \mathrm{O} 2$ with the different fuel blends. 


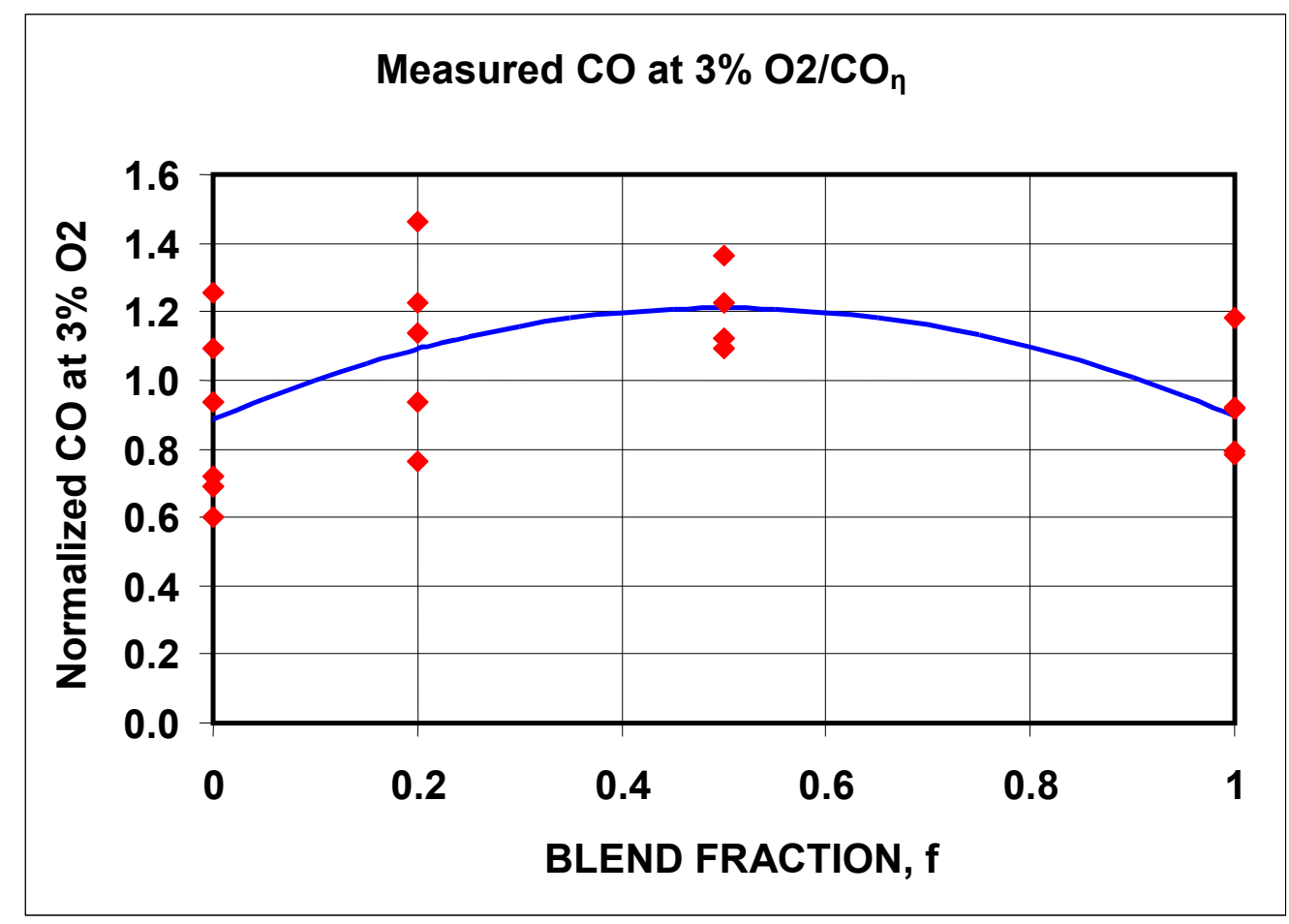

Figure 6.2 Normalized Carbon monoxide emission at $3 \% \mathrm{O} 2$ as a function of blend fraction.

Generally, the levels of carbon monoxide emissions are significant from the point of view of installation safety and as indications of incomplete combustion in the engine. As the actual measured levels could be important from the point of installation safety, Figure 7 gives these for ULSD use in the engine. The emission levels are below $50 \mathrm{ppm}$ except at zero load, when it is nearly 400 ppm.

Figure 8 gives the NOx emission results from a series of tests on the different fuel blends. The NOx values have been, again, corrected for dilution. As expected, the NOx values increase with the electrical load. If we disregard the scatter and some of the outliers, it does seem that the NOx levels are higher for the biodiesel (blends) than for the ULSD. This accords with what has been generally reported in the literature for diesel engines [11] and this has been one of the impediments to the use of biodiesel blends in diesel engines despite other benefits. The solid lines in this figure are the least squares polynomial fits to the data for each fuel blend and are given in Table 7 below.

Table 7. Regression fits for Figure 8: (P is the power in Watts)

$$
\begin{aligned}
& \text { ULSDEQ }=336.4-0.0505 \mathrm{P}+7.775 \times 10^{-5} \mathrm{P}^{2} \\
& \mathrm{~B} 20 \mathrm{EQ}=215.3+0.31 \mathrm{P}-6.11 \times 10^{-5} \mathrm{P}^{2} \\
& \mathrm{~B} 50 \mathrm{EQ}=375.2+0.81 \mathrm{P}-1.214 \times 10^{-4} \mathrm{P}^{2} \\
& \mathrm{~B} 100 \mathrm{EQ}=298.5+0.321 \mathrm{P}-2.078 \times 10^{-5} \mathrm{P}^{2}
\end{aligned}
$$


To find the average dependence of the NOx level with the electrical load, P, for all fuel blends, a least squares fit of all the data in Figure 8 was generated. This is shown in Figure 8.2. The solid line in this figure is given by:

$$
(\mathrm{NOx}) \eta=272+0.227 \mathrm{P}-5.858 \times 10^{-6} \mathrm{P}^{2} \quad \ldots \quad \ldots \ldots . \quad \ldots \ldots \text { (4) }
$$

Next, to estimate the variation of the NOx level with the blend fraction, the NOx level data in Figure 8 were divided by (NOx) $\eta$ calculated from Equation (4) above and plotted against the blend fraction. The results are plotted in Figure 8.3. The solid line in this figure is the regression fit:

Normalized NOx at $3 \% \mathrm{O} 2=0.82+3.12(\mathrm{f}-0.2)^{2} \cdot \exp ^{-2.1(\mathrm{f}-0.2)} \ldots \ldots \ldots(5)$

where, $\mathrm{f}$ is the fuel blend fraction. As stated earlier, while the NOx levels are high for high blend fractions, this limited data (see Figure 8.3) seem to suggest that for very low blend fractions, the NOx levels may be lower.

There is an interesting way to look at NOx production in diesel engines as illustrated by figure 8.4. This shows the NOx at $3 \% \mathrm{O} 2$ per unit watt of electrical output at various total electrical loads. While the general understanding is that NOx increases with load on the engine as, presumably, the temperature in the cylinder increases, figure 8.4 shows that the $\mathrm{NO}_{\mathrm{x}}$ per unit watt output is more or less constant with load for ULSD and reduces with load for biodiesel. This is somewhat counter-intuitive in view of the increased cylinder temperatures at higher loads and especially, the behavior with biodiesel seems to need explaining. Also, the value for biodiesel is higher than that for ULSD, but more so at low load than at high load.

\section{CO as measured for ULSD}

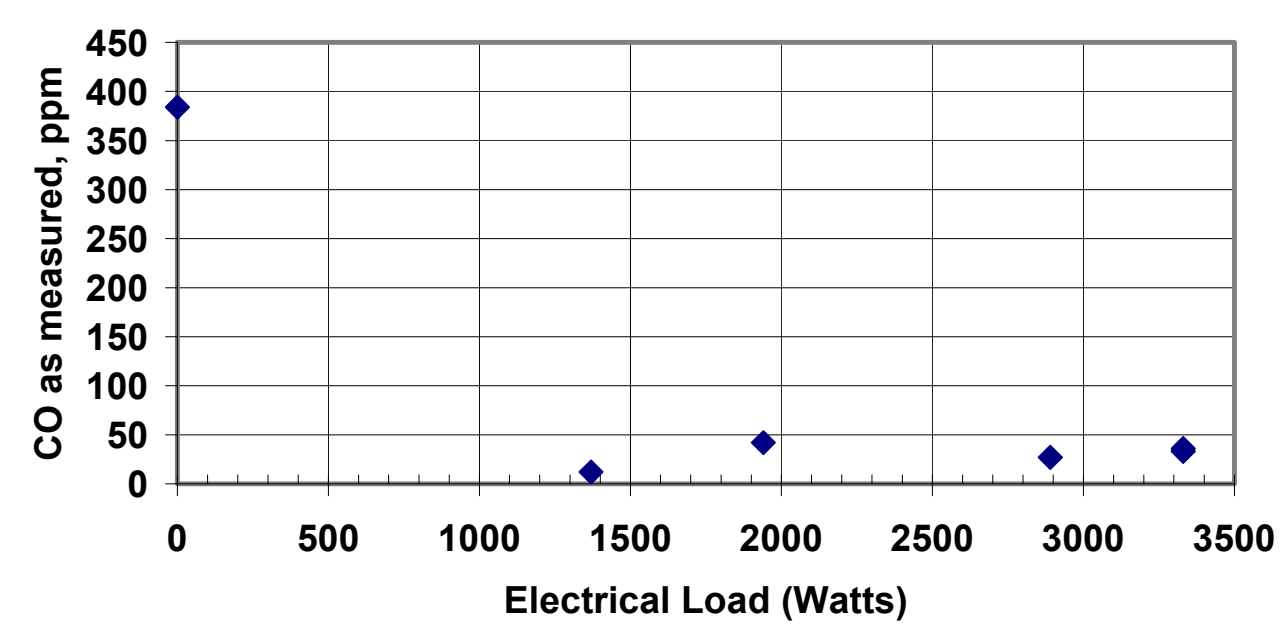

Figure 7. Carbon monoxide emission as measured from ULSD as fuel. 


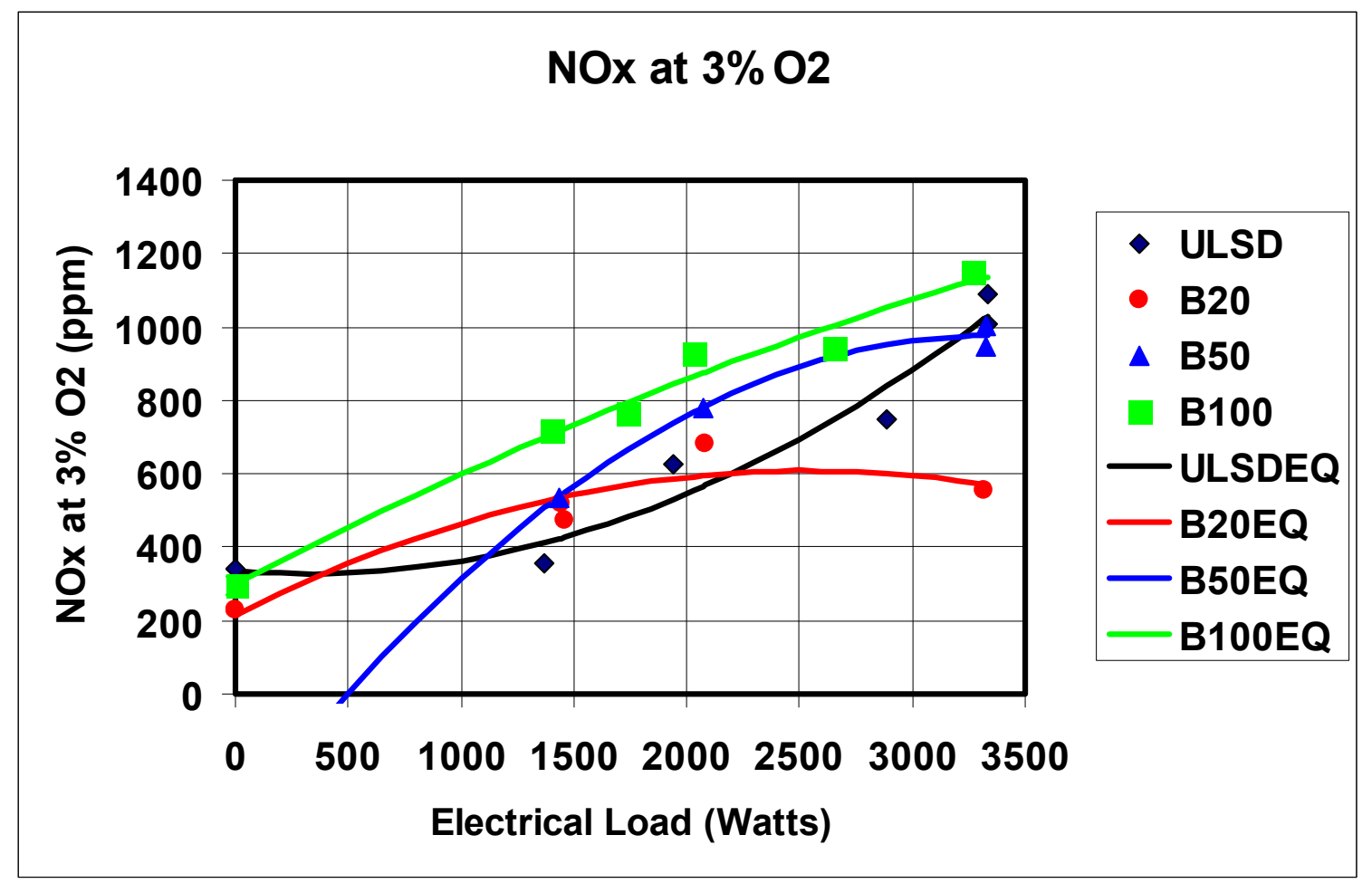

Figure 8. NOx emission from the different fuels.

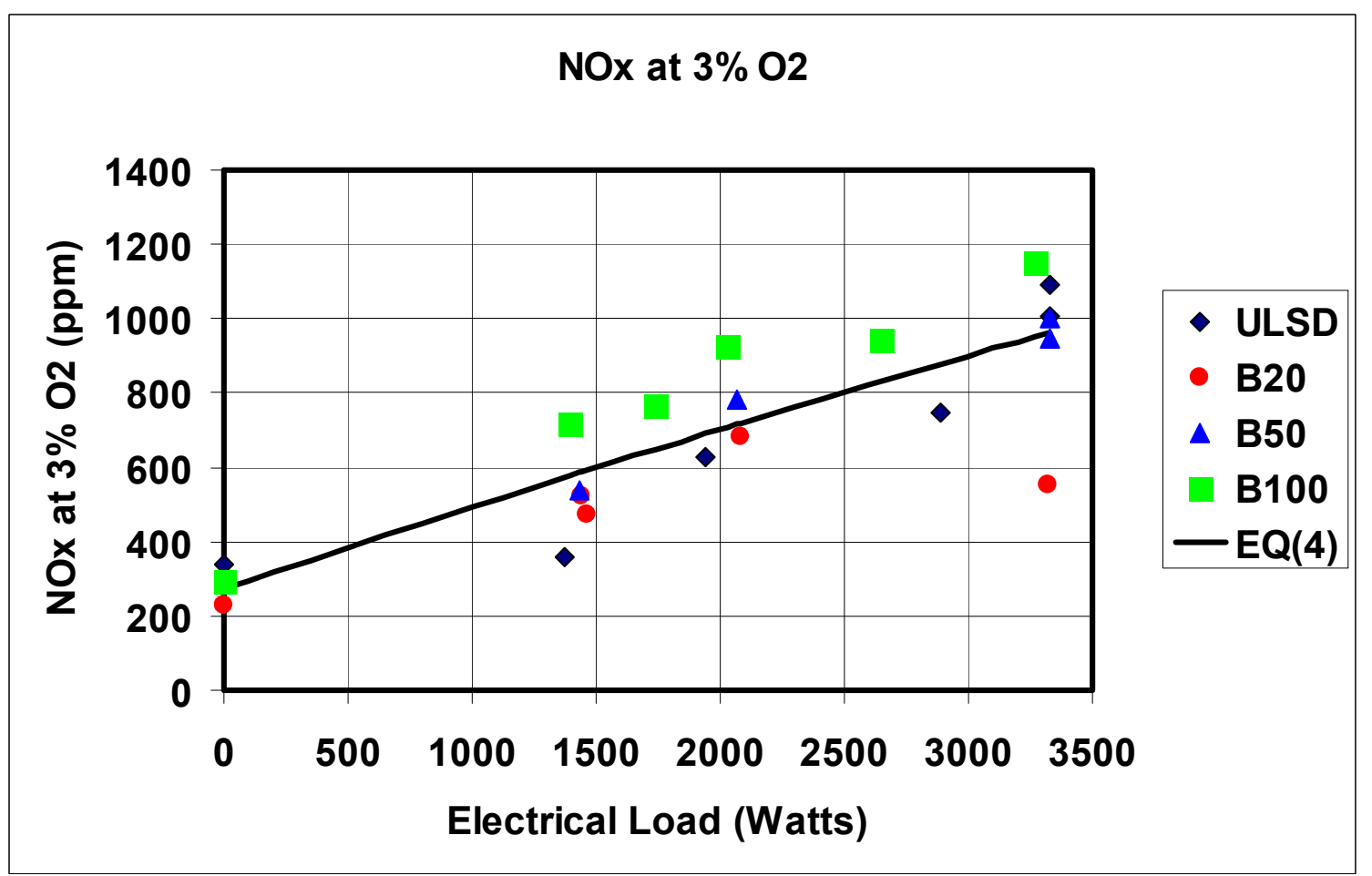

Figure 8.2 NOx emission from the different fuels. 


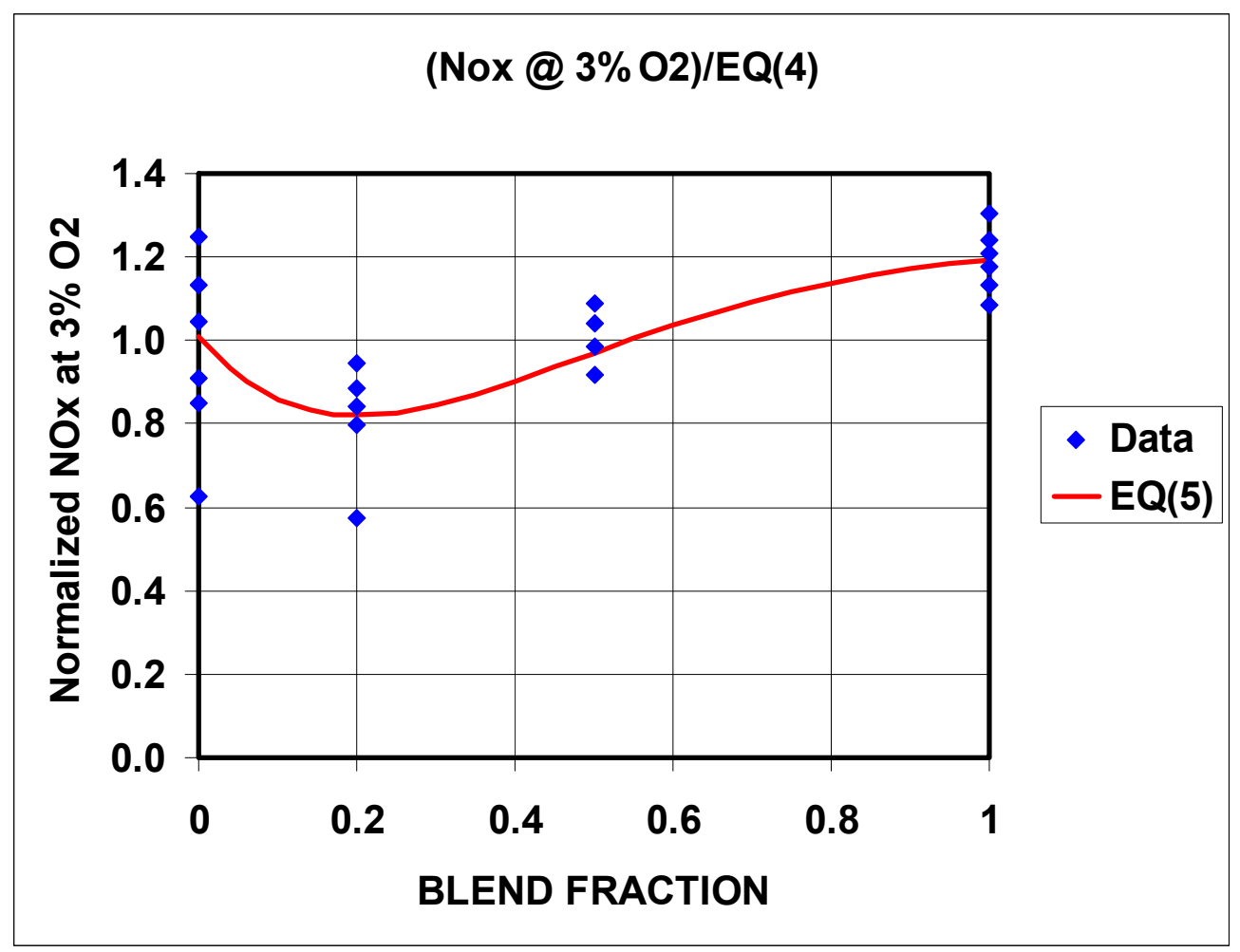

Figure 8.3 Variation of NOx levels with the blend fraction.

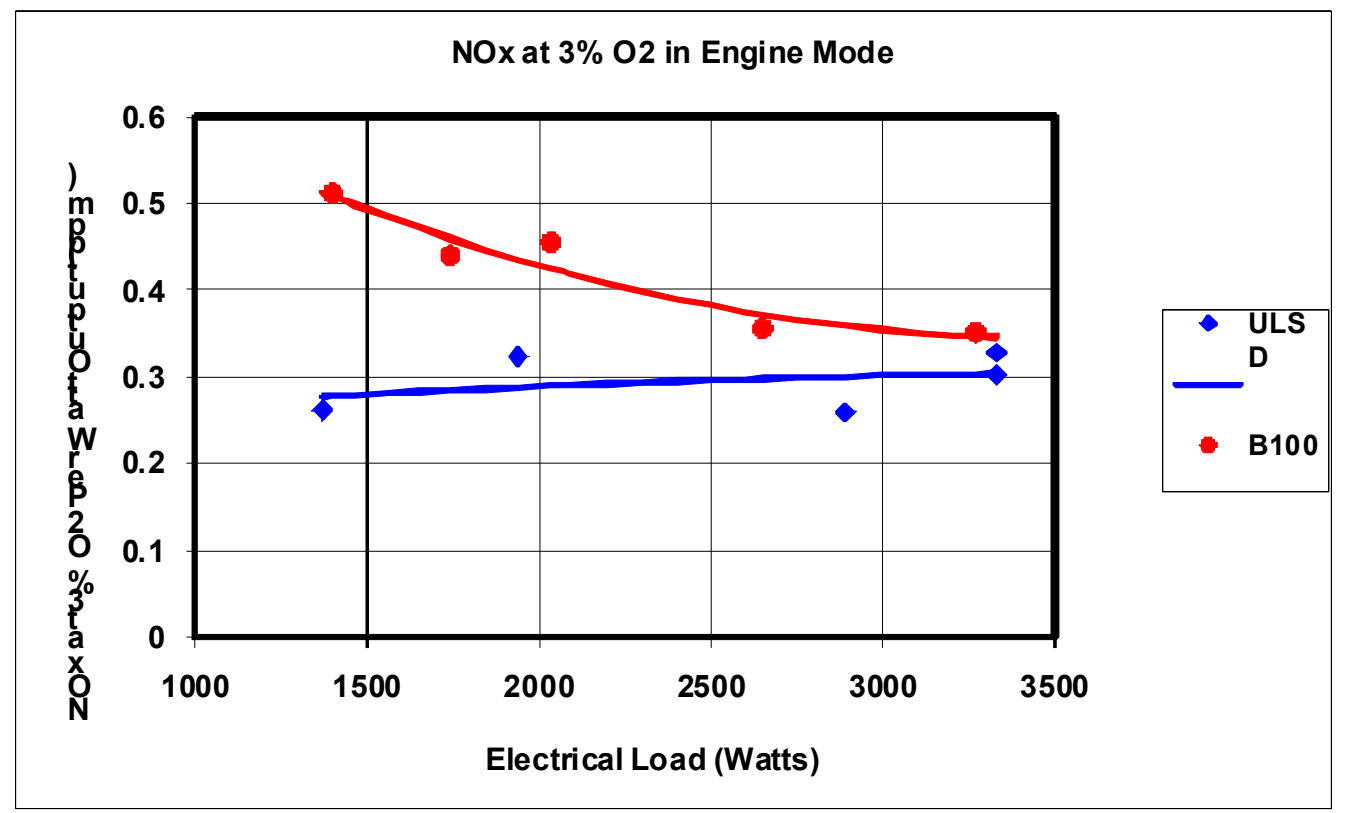

Figure 8.4 NOx per watt output 


\subsubsection{HCCI/mixed mode tests}

In this mode of testing typically, the engine would be started and warmed up in the normal mode before the electrical load was connected. Then, the atomizer nozzle would be heated to a pre-determined temperature, which was $300^{\circ} \mathrm{F}$ for all the tests. The auxiliary pump used to pump the fuel to the atomizer would be started and the exit pressure would be adjusted with the outlet valve. The intention was to test at a range of ratios of fuel flow rate through the atomizer to the total flow rate into the engine, termed the atomizer flow fraction here. It is expected that the governor in the engine would cut back the fuel flow to the engine injector as the flow through the atomizer was increased. This seemed to work over a range of flows, but there were limitations to the atomizer fuel system that limited the range. Also, the governor did not seem to be capable of completely cutting off the fuel to the injector in a loaded, running engine and so operation on the full HCCI mode could not even be attempted. Also, it is not clear whether one could achieve successful compression ignition or smooth operation in such a situation. It is not clear from the published literature $[3,5]$ as to how and whether this was achieved.

Figure 9 below gives the efficiency of the engine operated on the ULSD in the mixed mode. The electrical load and the fraction of atomizer flow, defined as the ratio of the flow rate through the atomizer (into the engine intake for HCCI operation) to the total flow rate of fuel into the engine, were both varied. For comparison, the electrical efficiency of the engine on the same fuel in the baseline test is also plotted, obviously the atomizer flow being zero for this set of data. At higher loads, the efficiency under the HCCI or mixed mode operation tends to be lower than under the baseline engine mode. The solid green line in this figure is the least squares fit to all the data in this figure and is given by:

$\eta=0.148+0.0065(\mathrm{P} / 3500)+0.065(\mathrm{P} / 3500)^{2} \quad \ldots . \ldots \ldots \ldots$

To remove the primary influence of the electrical load on the electrical efficiency, the measured efficiency was divided by the calculated $\eta$ from Equation (6) above. The resulting "normalized" efficiency is plotted against the atomizer flow fraction in Figure 10. The green square data points are for runs during which only the atomizer fraction was varied while the electrical load was virtually constant at $3.3 \mathrm{~kW}$.

Figure 11 below gives the $\mathrm{CO}$ emission in the exhaust for the same series of tests. The data clearly show that the $\mathrm{CO}$ emissions with HCCI are higher than those during normal engine mode and significantly so at partial loads. This could be the result of 'lower' combustion temperatures particularly at lower loads and possibly 'delayed' combustion of the atomized fuel through the intake.

Figure 12 shows a plot of data for "as measured" CO levels for only those runs during which the electrical load was virtually constant (between $3.22 \mathrm{~kW}$ and $3.33 \mathrm{~kW}$ ). The data are plotted as a function of the atomizer flow fraction. The results show an increase in emitted CO with increasing atomizer flow fraction consistent with the reason indicated above.

A comparison of NOx levels for the normal engine mode and the HCCI mixed mode for ULSD fuel is shown in Figure 13, which shows that the NOx levels are lower significantly during HCCI operation. The solid lines in this figure, given by Equations (7) and (8) below, are the best fits to the "engine" and "HCCI" data respectively.

Engine $\mathrm{NOx}$ at $3 \% \mathrm{O} 2=274+182(\mathrm{P} / 3500)+659.8(\mathrm{P} / 3500)^{2} \quad \ldots \quad \ldots(7)$ 
HCCI NOx at $3 \% \mathrm{O} 2=-113+998(\mathrm{P} / 3500)-183(\mathrm{P} / 3500)^{2}$

To find the dependence of the NOx level on atomizer flow fraction, as before, the measured NOx values for HCCI cases (reduced to $3 \%$ O2) were divided by the computed fit Equation (8), and plotted against the atomizer flow fraction. These normalized NOx values are plotted in Figure 14 and it can be seen that the NOx values decrease with increasing atomizer flow fraction.

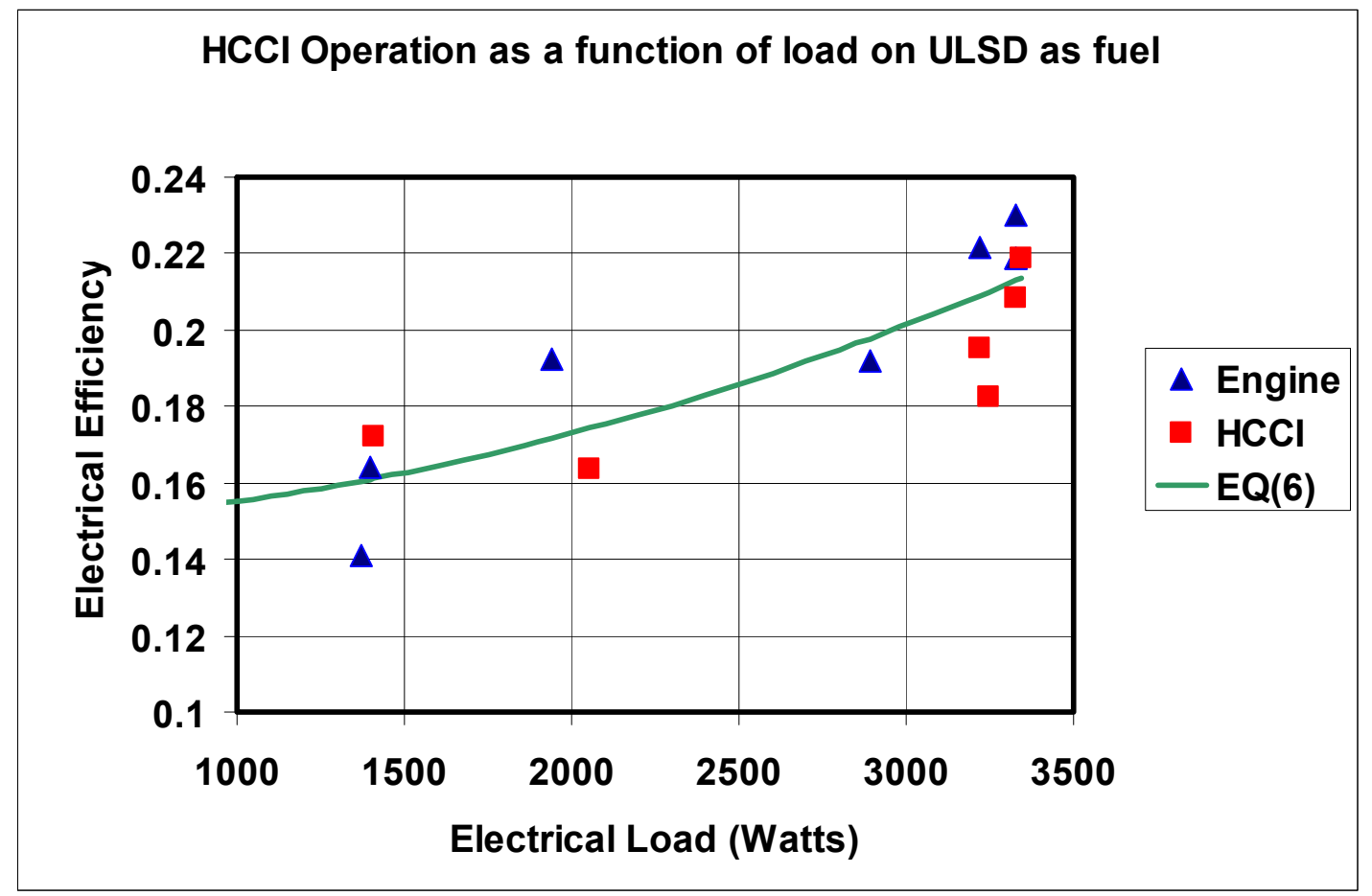

Figure 9. Efficiency under HCCI (mixed mode) operation on ULSD fuel 


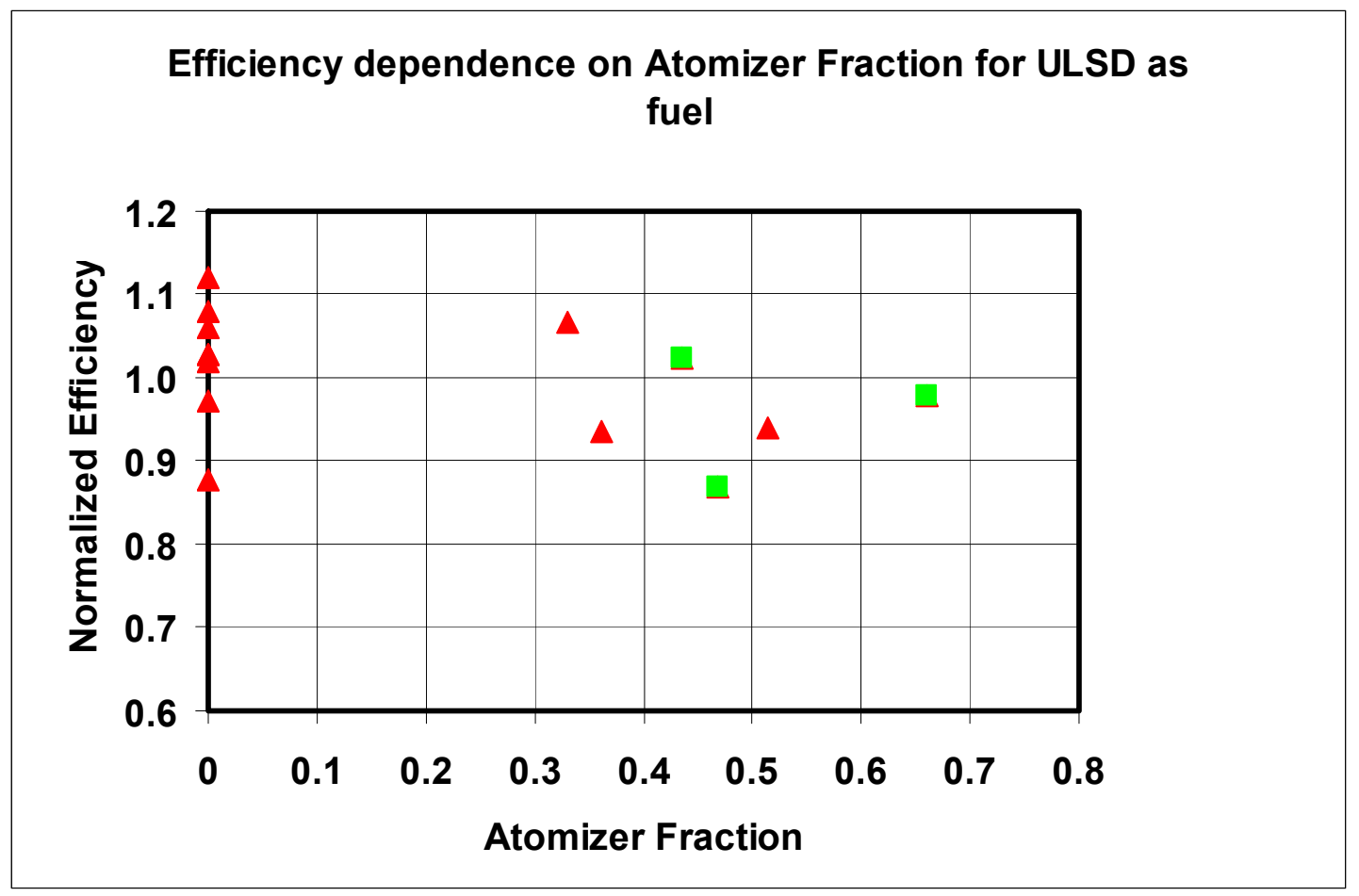

Figure 10. Normalized efficiency as a function of atomizer flow fraction under HCCI operation for ULSD fuel. Square symbols are data at constant electrical load of $3.3 \mathrm{~kW}$.

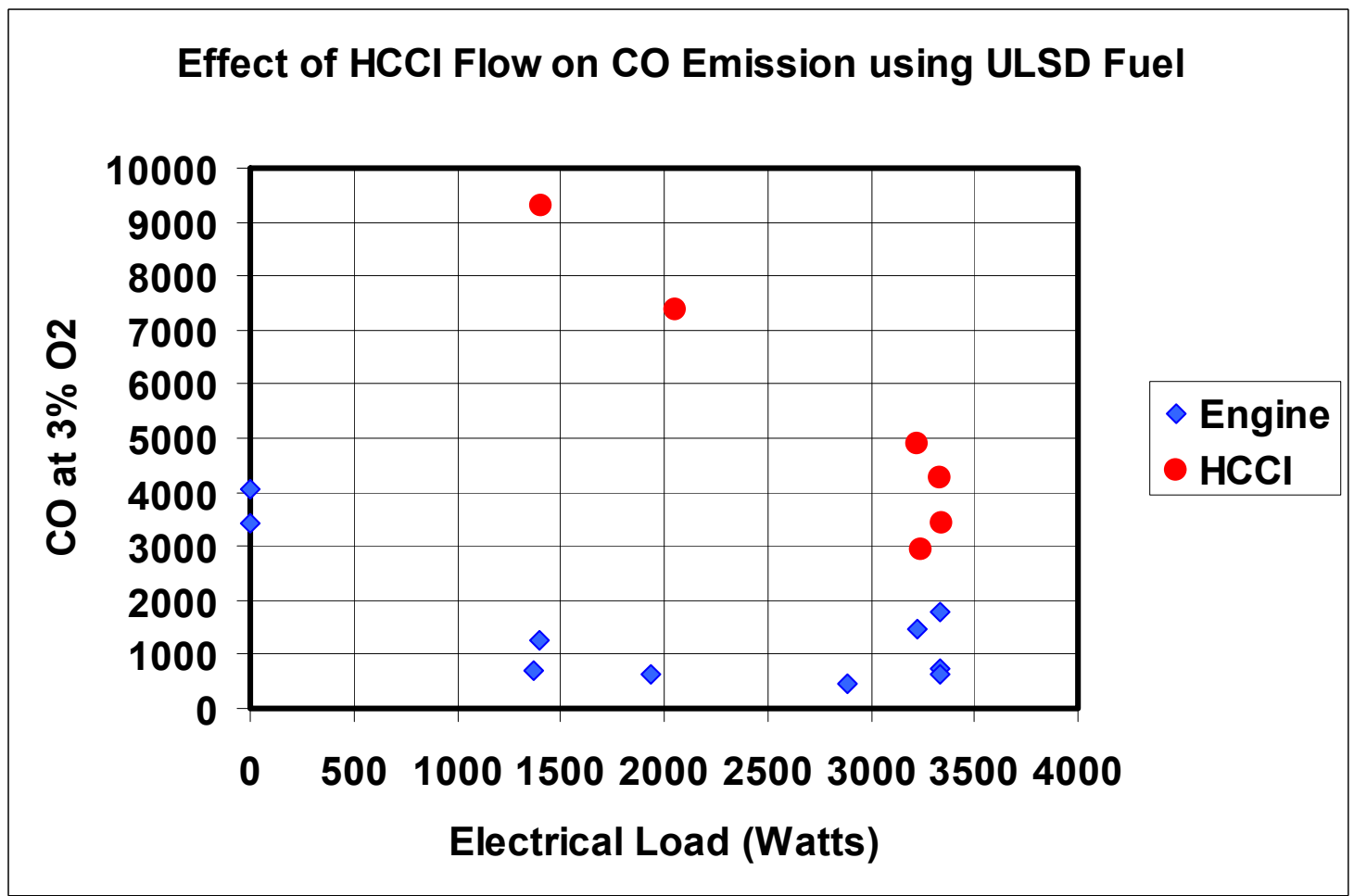

Figure 11. CO emission under normal injection and mixed mode HCCI operation using ULSD fuel 


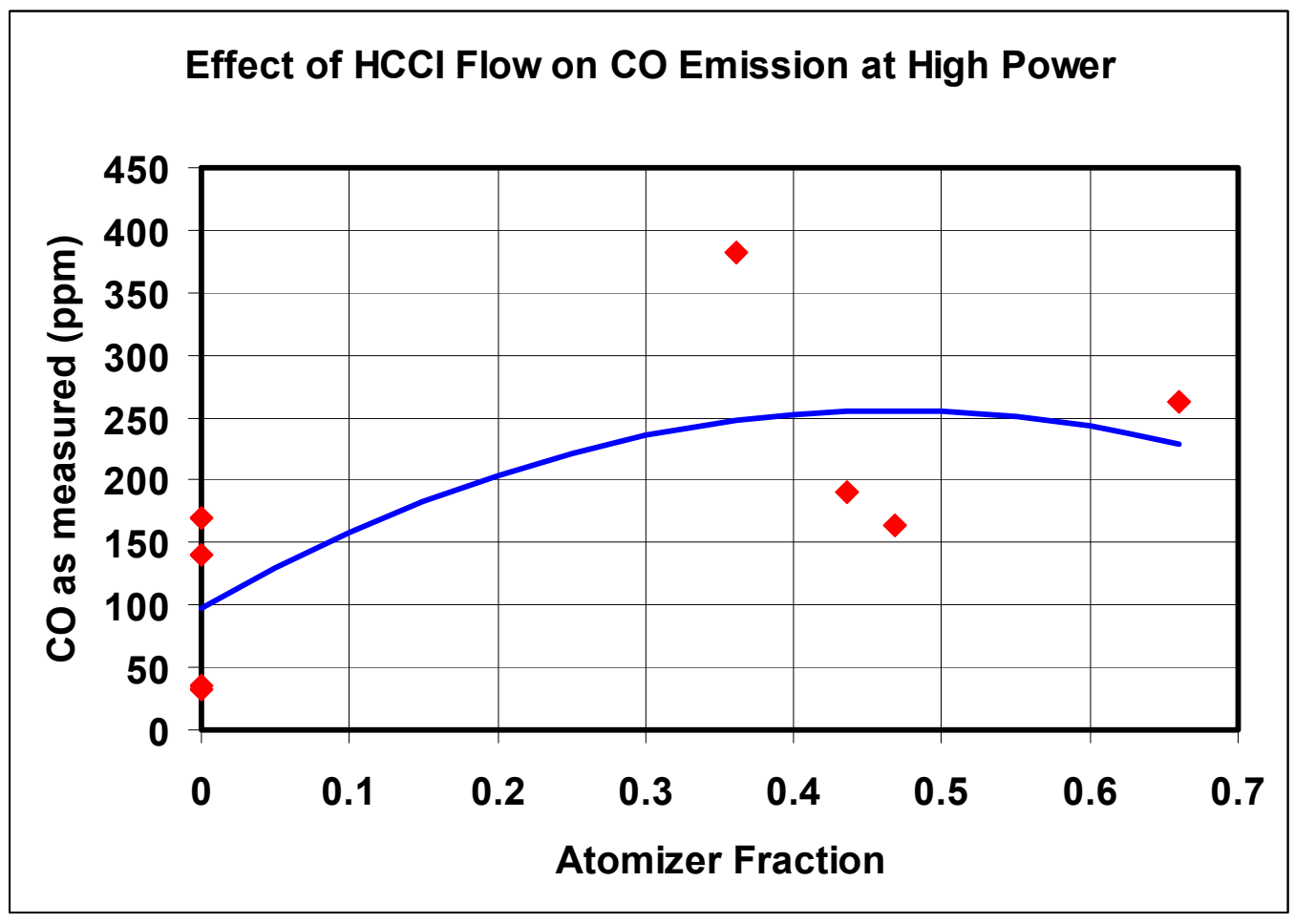

Figure 12. CO as measured as a function of Atomizer Fraction at constant electrical load (3.22 to $3.33 \mathrm{~kW})$.

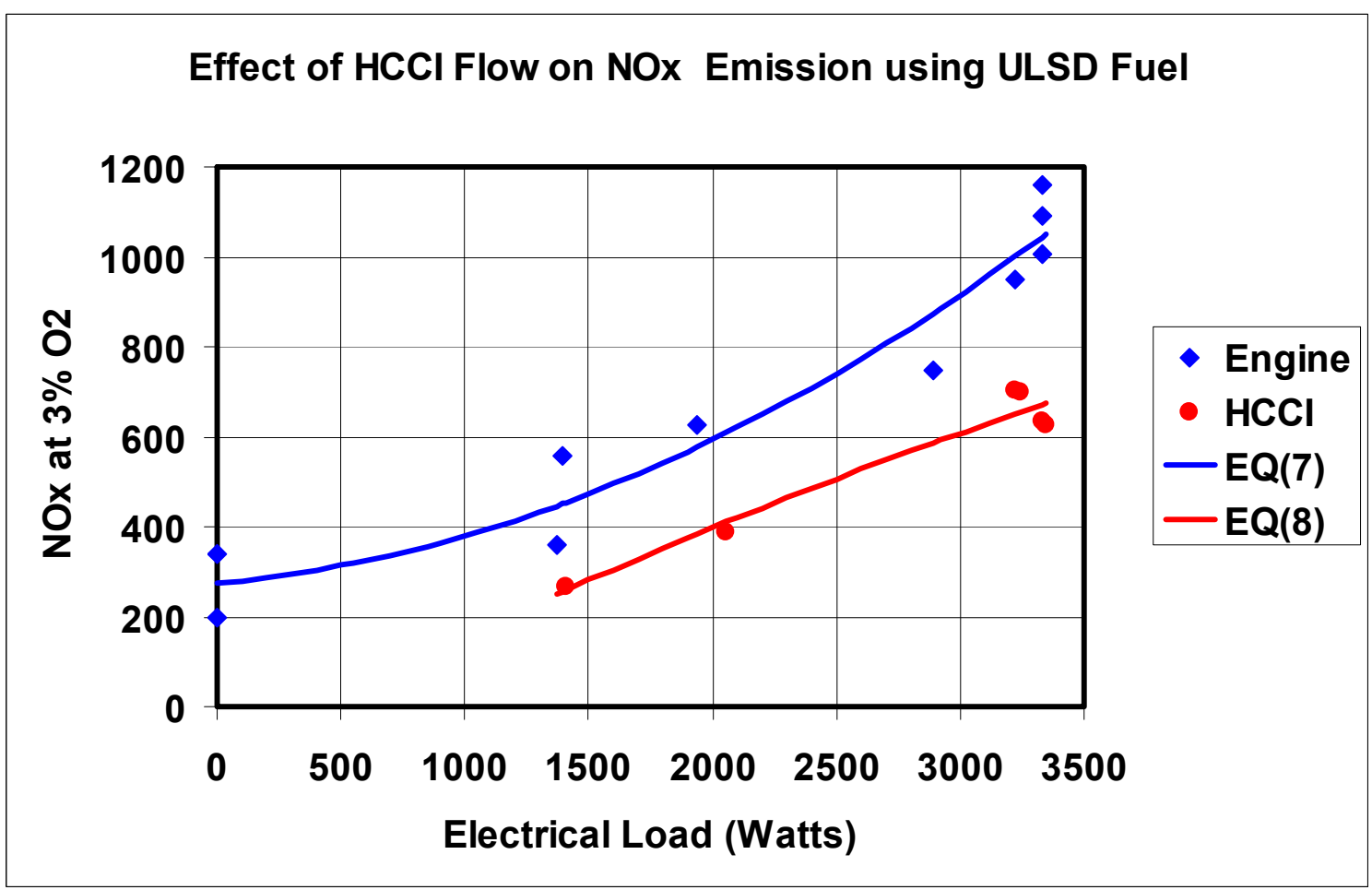

Figure 13. A comparison of NOx levels at $3 \% \mathrm{O} 2$ for normal engine injection and mixed mode HCCI for ULSD fuel. 


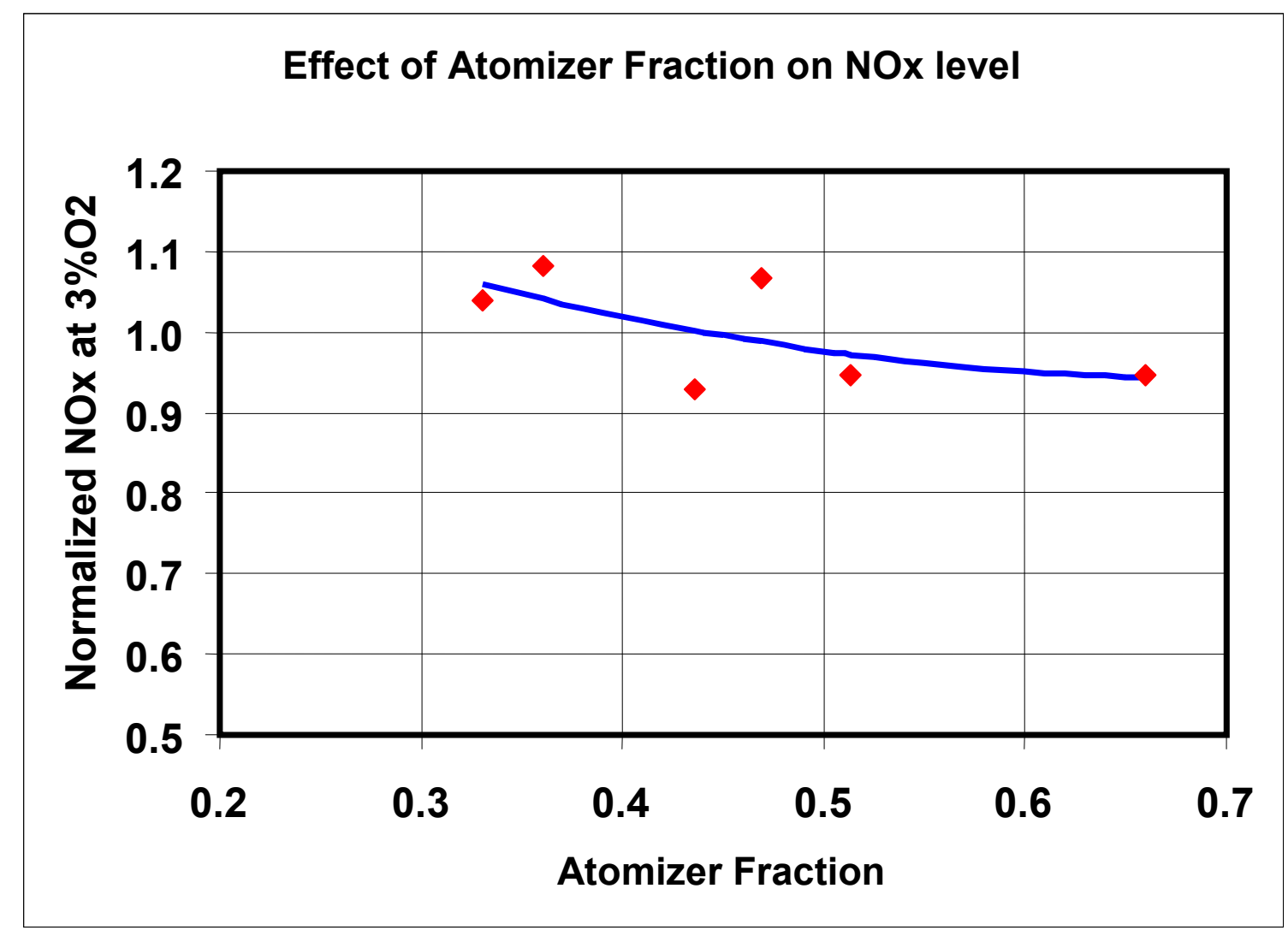

Figure 14. Variation of normalized NOx levels at 3\% $\mathrm{O} 2$ with the atomizer fuel fraction for mixed mode HCCI with ULSD fuel.

Similar mixed-mode operation tests were conducted with Biodiesel as the HCCI fuel. The only operational difference was that ULSD was used in the main engine injector. This is not required, of course, and tests were conducted to demonstrate that the engine could be run using only biodiesel in the mixed mode. This is not surprising, as previous engine experiments have shown that diesel engines can be run on $100 \%$ biodiesel as fuel. The results are presented as above in figures 15 through 20. Figure 15 shows that the electrical efficiency under mixed-mode (HCCI) operation is less than under normal or engine mode operation under high loads. Ganesh et al [5] find a reduction of about $4 \%$ in brake thermal efficiency at $75 \%$ load and as noted in section 2, they vaporized the diesel before induction. Garcia et al [12] in a recent paper reported results of HCCI operation in a single cylinder engine using early injection into the cylinder directly, intake air heating and exhaust gas recirculation. At high loads, they report specific fuel consumptions during HCCI operation of more than double that under normal engine mode. The reasons for the loss in efficiency could have similar and different reasons. In our case, it includes loss of fuel in the intake manifold, and slower and more incomplete combustion in the cylinder. The latter does result in higher $\mathrm{CO}$ emission and possibly higher unburned hydrocarbons although the latter was not measured. The publications cited do see these as well. Figure 16 compares efficiencies in mixed-mode operations on ULSD and Biodiesel. The engine, probably not surprisingly, has higher efficiencies on ULSD than on B 100. Figure 17 compares the efficiency variation with the fraction of fuel flow from the atomizer into the intake manifold. Not surprisingly, the efficiency decreases with increase of this flow. However, since the Electrical 
load is a variable in the data plotted in this figure, this variation with atomizer fraction is likely to be misleading. Therefore, to take out the general dependence (for this engine) of efficiency with electrical load, $P$, the measured efficiency was divided by $\eta$ calculated from Equation (1) above $\left\{\eta=0.2125+0.01(\mathrm{P} / 3500)-0.00439(\mathrm{P} / 3500)^{-3.26}\right\}$ and the 'normalized data' are plotted as figure 18 below. The effect of atomizer flow fraction seems to be less pronounced from this figure.

Figures 19 and 20 compare the NOx produced (corrected to 3\% O2) by mixed-mode operation with engine mode operation. As before, clearly HCCI operation gives lower NOx, both in total emission and also in NOx per watt produced at all loads tested.

One of the benefits claimed for the use of biodiesel in engines is the reduction in the emission of smoke or fine particulates compared with diesel fuel. Fine particulate measurement using the PM2.5 system that is available to us was impossible in the present configuration of such a small engine. Hence, it was decided to measure the smoke using the standard Bacharach method with a hand-operated pump [13]. The results are presented in figure 21. It is seen that, in the engine mode of operation, the smoke numbers with biodiesel are consistently lower than with ULSD over the entire load range tested. Dabill [14] has developed a correlation between, the amount of elemental carbon in the soot from diesel engines on the filter used to measure smoke numbers, and, the Bacharach or Bosch smoke number. While it is not entirely satisfactory as a measure of PM2.5, it does give an estimate of fine particulates. This correlation was used to develop the data plotted in figure 22 from the data in figure 21. This shows that the particulate loading is significantly lower for B 100 compared to the baseline diesel at the higher loads. The small increase seen at lower loads is really an aberration due to the correlation in reference 14 and does not reflect the lower smoke numbers seen in the previous figure. Figure 23 shows the results of smoke measurements under the HCCI or mixed-mode of operation with ULSD as the fuel. The smoke numbers are comparable with an indication of lower smoke with HCCI mode at the highest load tested. 


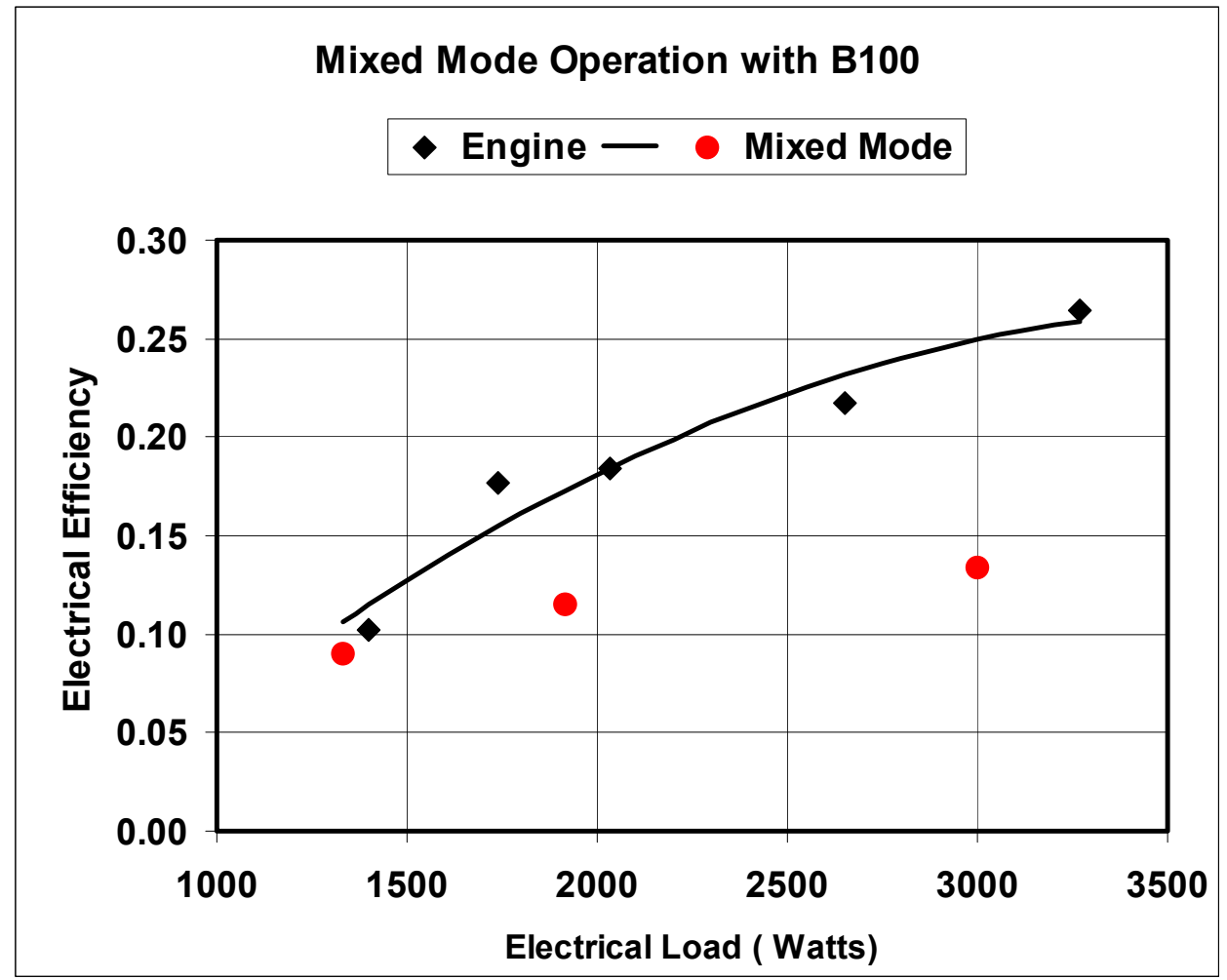

Figure 15. Efficiency under mixed-mode and engine operation with Biodiesel

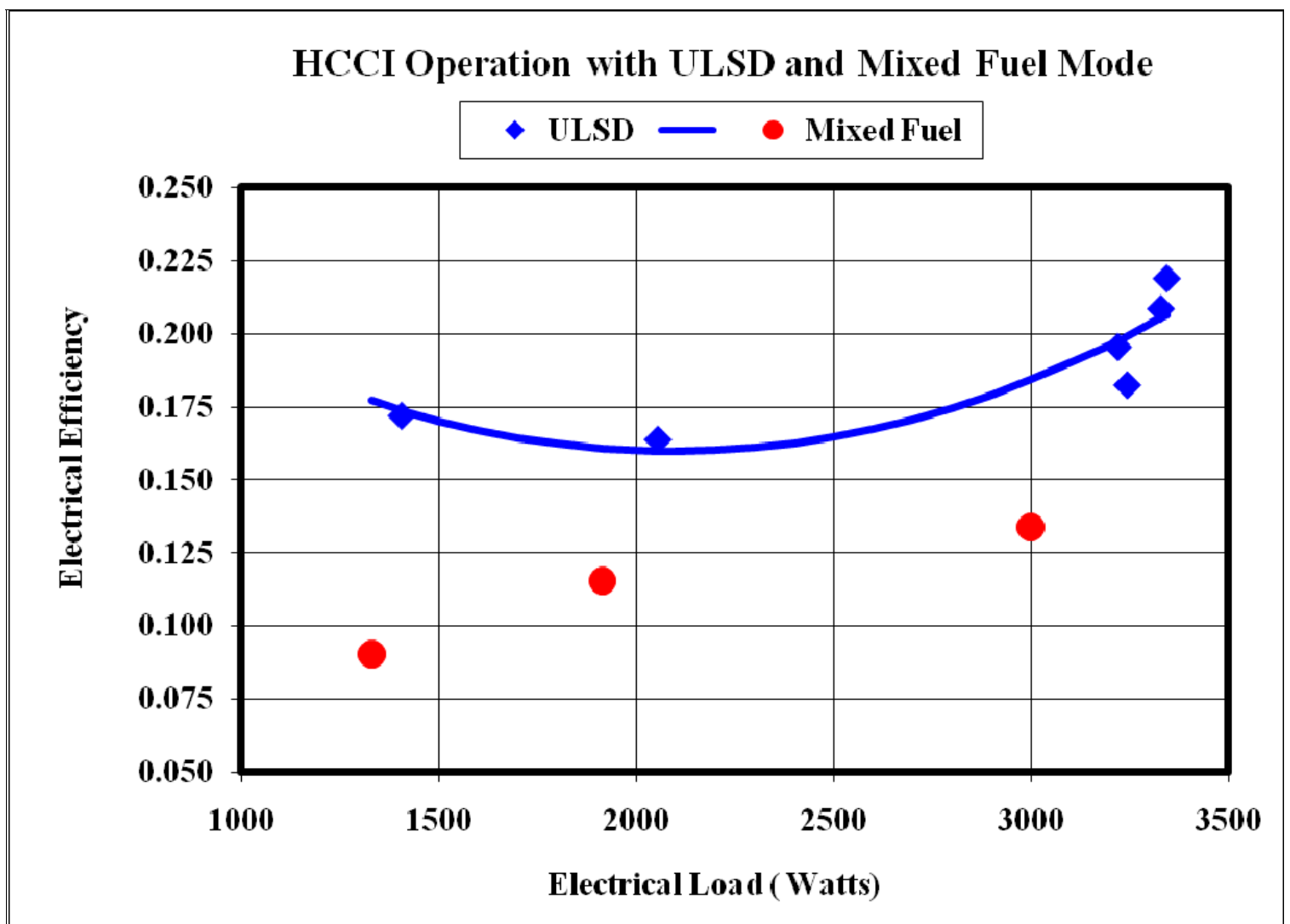

Figure 16. Efficiency under mixed-mode ( $\mathrm{HCCl})$ operation with ULSD and Biodiesel 


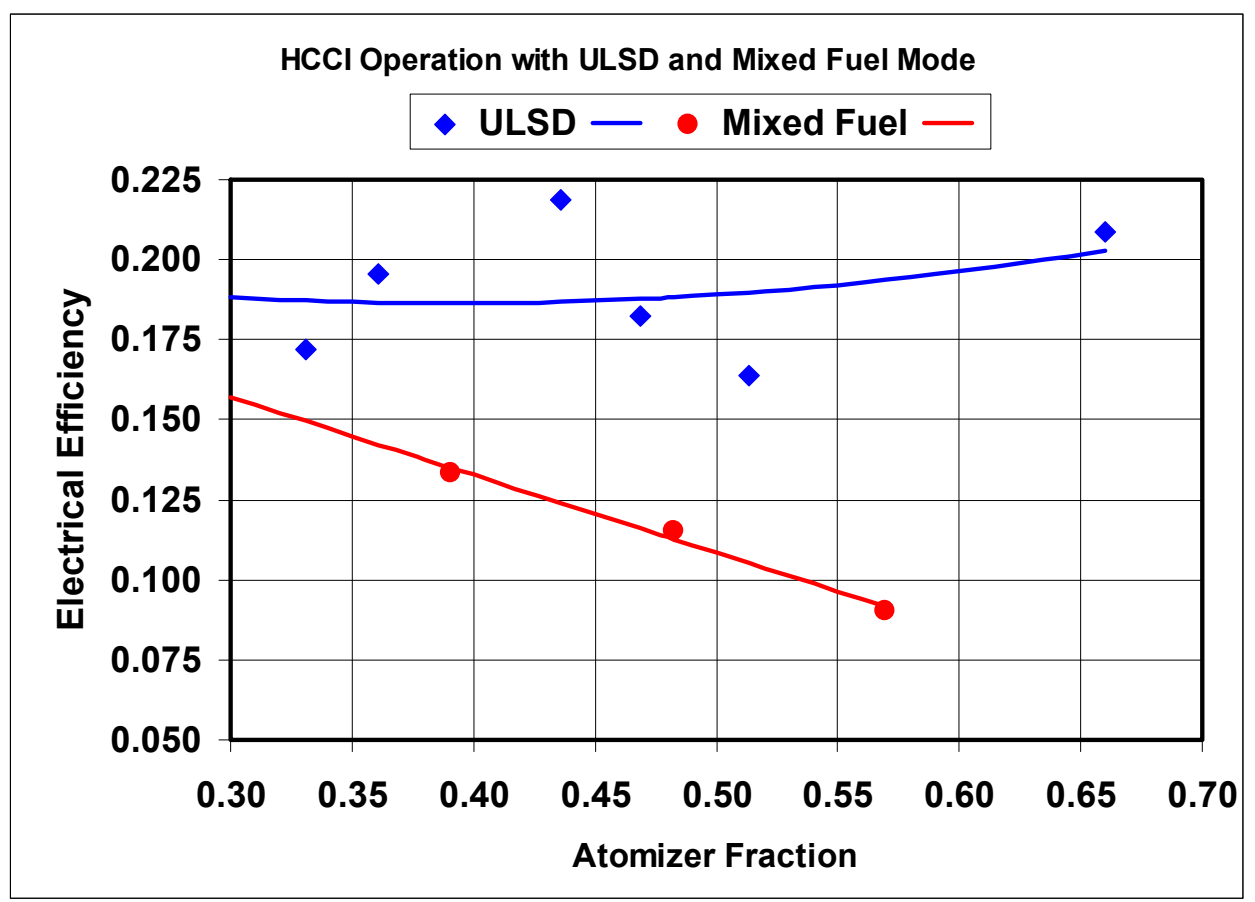

Figure 17. Efficiency as a function of atomizer flow for the two fuels

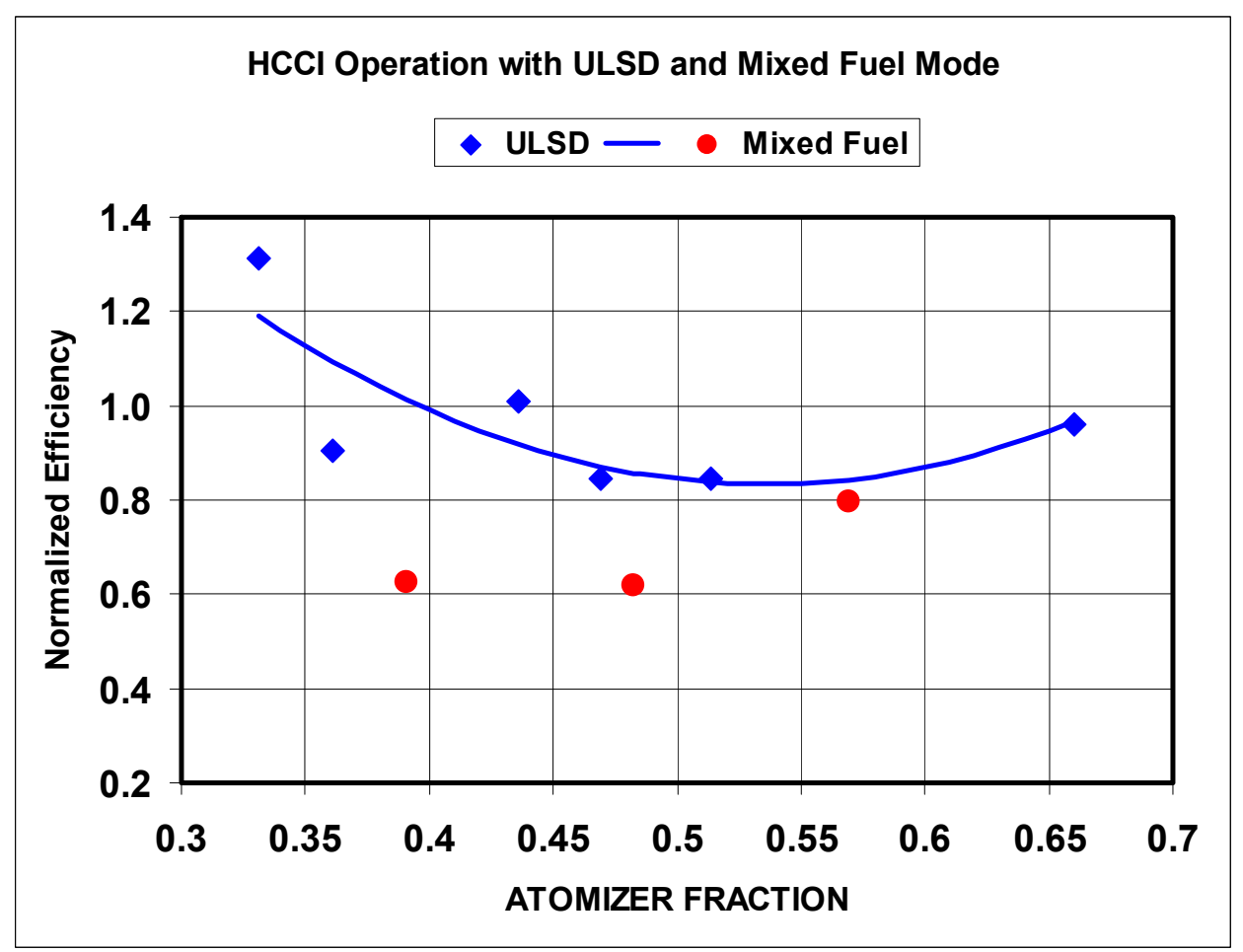

Figure 18. Normalized efficiency as a function of atomizer flow fraction. 


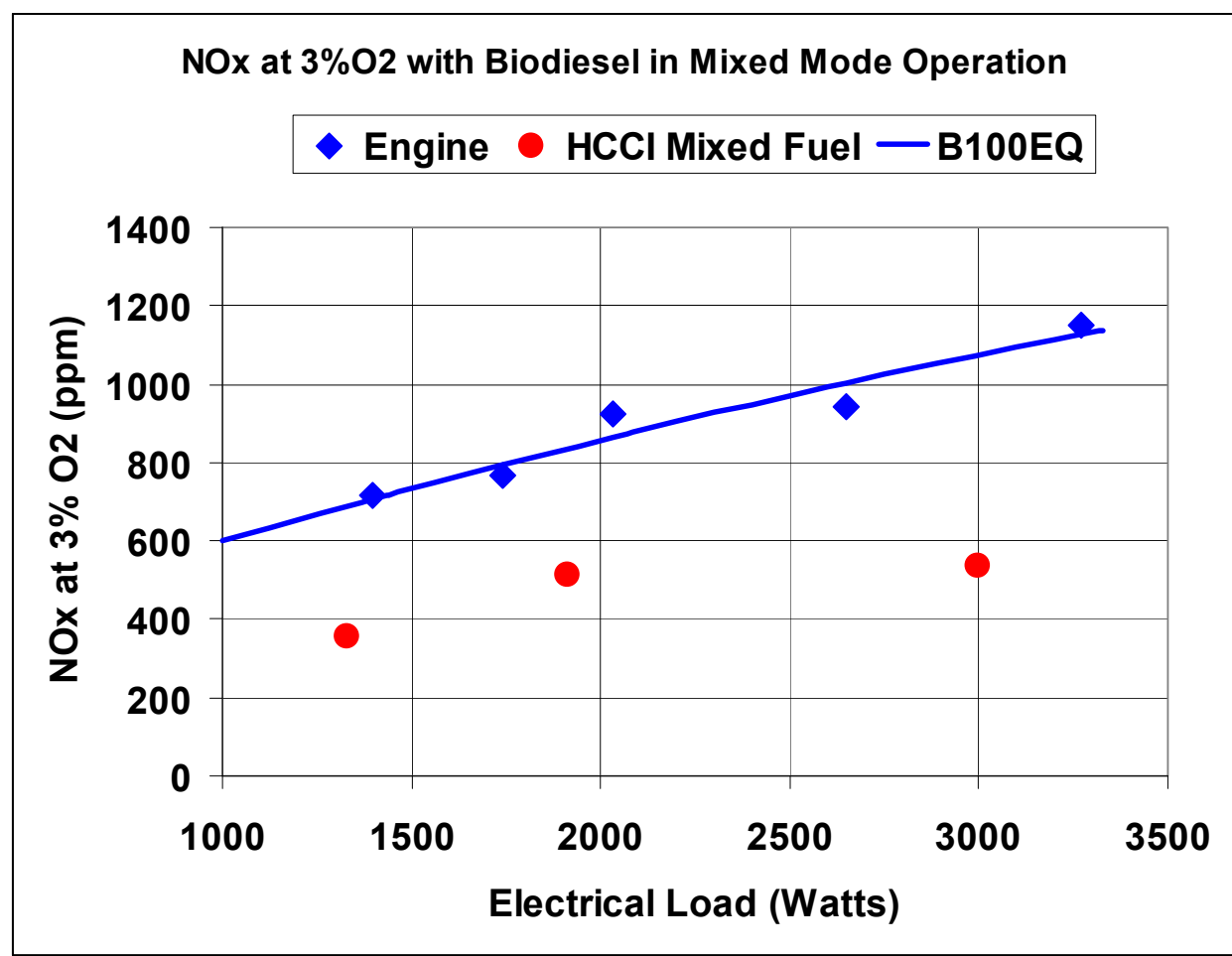

Figure 19. NOx at $3 \% \mathrm{O} 2$ with $\mathrm{B} 100$ in engine and in mixed-mode operation

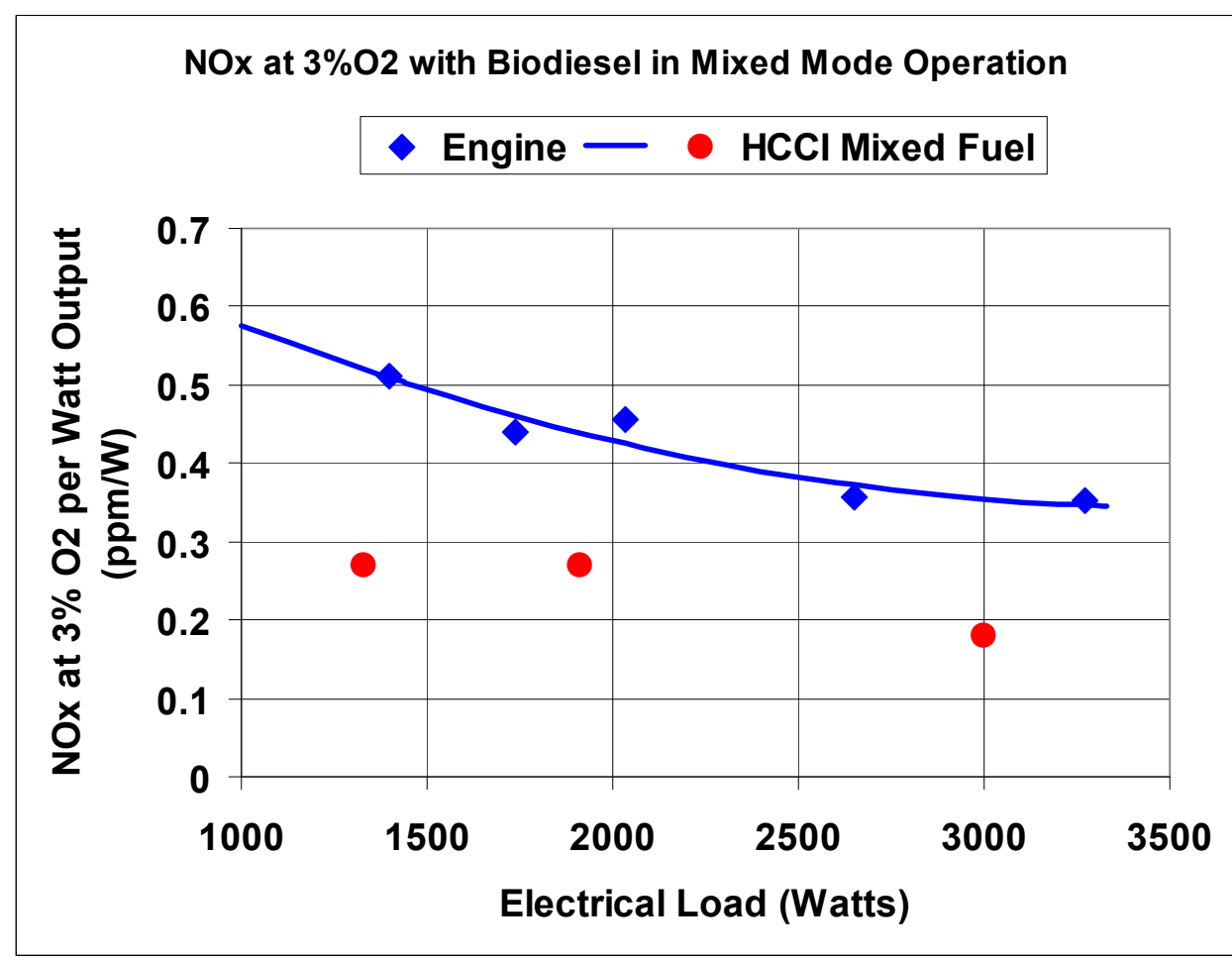

Figure 20. NOx at $3 \% \mathrm{O}$ per Watt output for B100 in engine mode and mixed-mode 


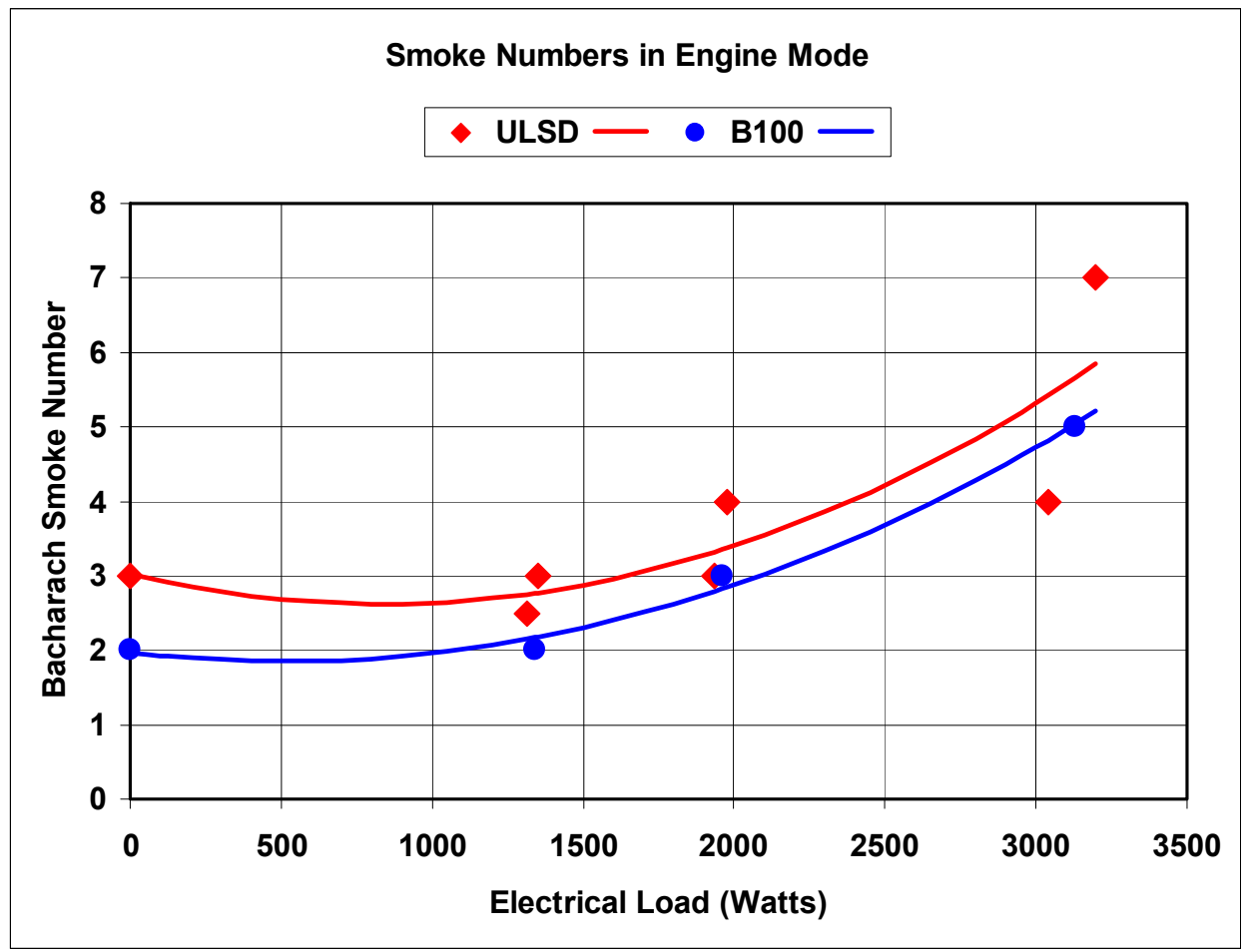

Figure 21. A comparison of Bacharach Smoke Numbers in the Engine mode

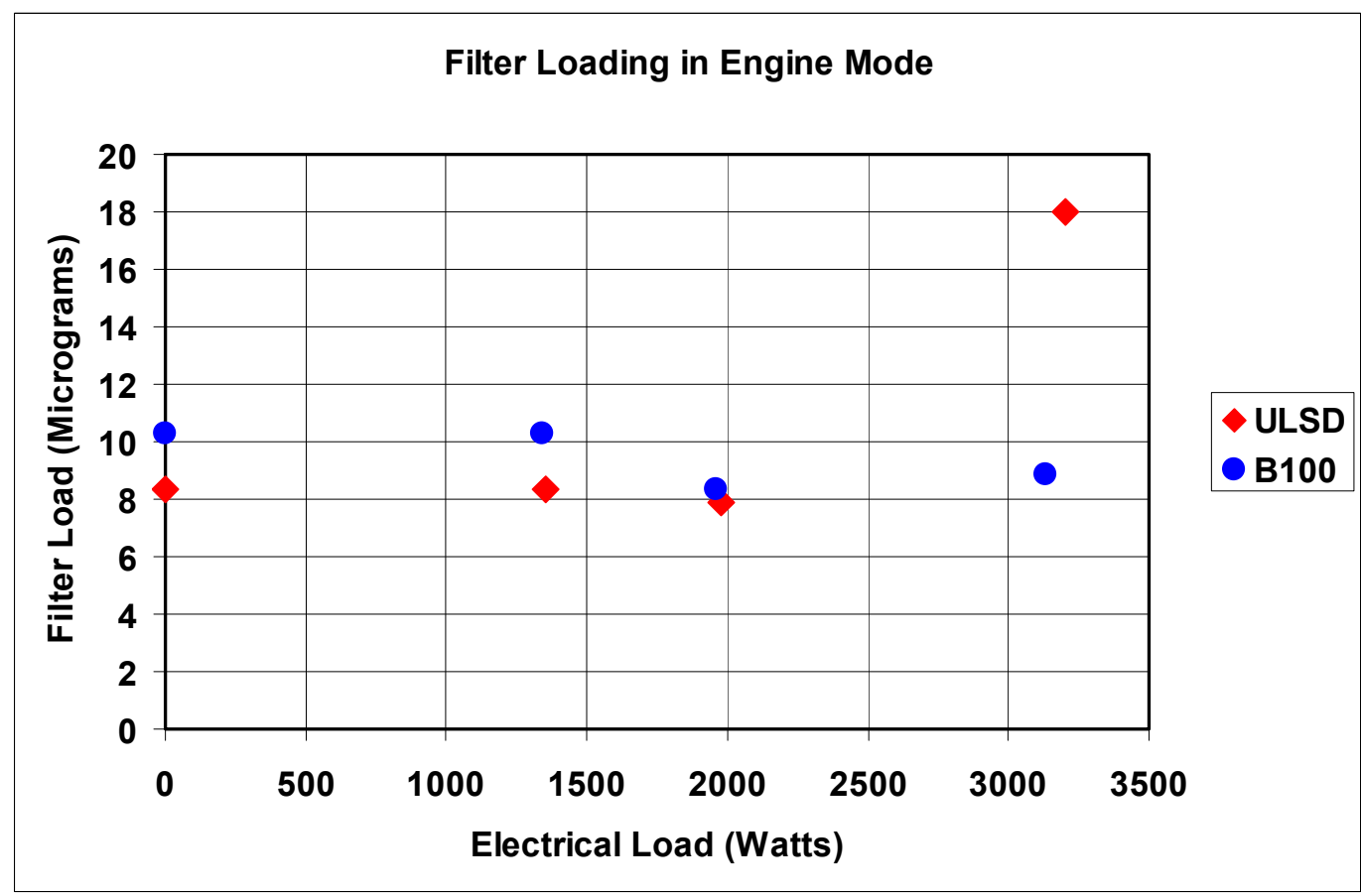

Figure 22. Filter loading in the Engine mode for ULSD and B100 fuels. 


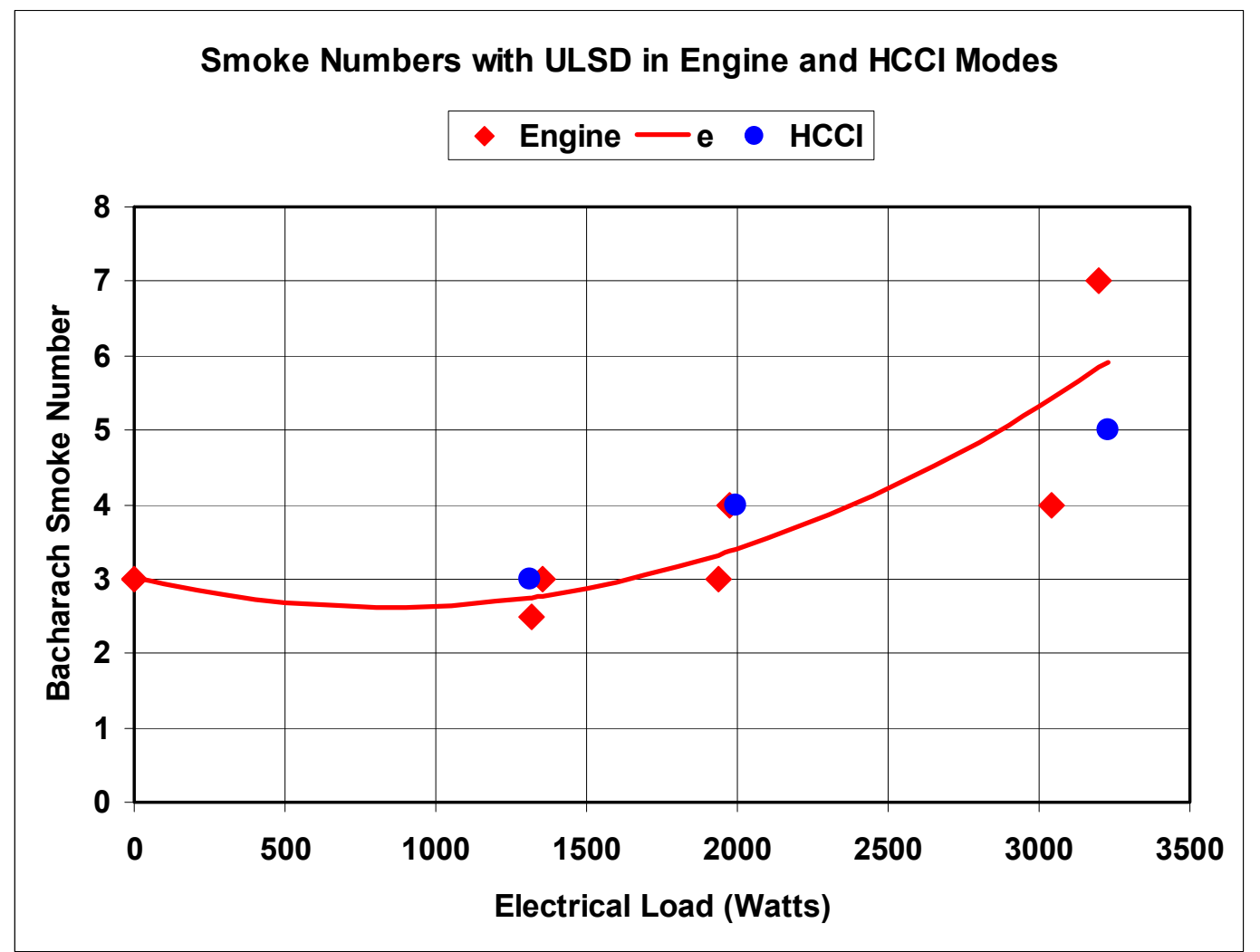

Figure 23. A comparison of Bacharach Smoke Numbers for the Engine and HCCI modes. With ULSD as fuel.

\subsection{Combined Heat and Power (CHP) Operation}

\subsubsection{Experimental}

The idea with combined heat and power operation is obviously to use the 'waste heat' during engine operation to supply the heat load in the building. The analytical work done by Dr. John Andrews examines this in good detail using several scenarios. In terms of practical implementation, this would require that, in addition to the generator output being connected to the electrical system of the residence appropriately, the heat from the engine has to be fed into the heating system in an appropriate way. The latter requires heat exchangers in the engine cooling hot water circuit and in the engine exhaust gas line. The development of this hardware and integrating into the system is not part of this project, but is obviously required to implement a micro-CHP. A simple experiment was done to measure the amount of heat rejected to the cooling water by the engine when supplying an electrical load of about $3 \mathrm{~kW}$. The heat rejected was approximately about $4 \mathrm{~kW}_{\mathrm{t}}$. The maximum water temperature is about $75^{\circ} \mathrm{C}$ and so the operating temperature will be lower than this. This and the temperature of heat storage (if a hot water storage tank is used) will determine the heat exchanger design and the two together will determine how much of this 'waste heat' can be useful to satisfy the thermal load. If the electrical efficiency is about $20 \%$ (see figure 5 above) and the generator efficiency is $80 \%$, the fuel input energy is $12 \mathrm{~kW}$ equivalent and the 'waste heat' in the exhaust is about $5 \mathrm{~kW}_{\mathrm{t}}$. Typical exhaust gas temperature at an electrical load of $3 \mathrm{~kW}$ and at steady state was measured as about $300^{\circ} \mathrm{F}$. A part of this waste heat is available for transfer to the residential heating system with a suitable heat exchanger and control system for safe operation. As the heat exchanger surfaces see 
the hot and 'dirty' exhaust gas, the materials of construction will have to be chosen appropriately.

\section{$\underline{4.4 .2 \text { Analytical work }}$}

Reference was made to the work done by Dr. John Andrews under subcontract in the course of the project to map the performance of a micro-CHP system in two 'typical' locations, one representing Albany, NY and the other Long Island, NY. The full report on this work is included as the Appendix below. Some of the key results will be summarized for only the Long Island location below. Broadly speaking, the Albany location shows similar results qualitatively, but with quantitative differences.

Figure 24 below shows the annual primary energy savings when the CHP system is used to supply both domestic hot water (DHW) and space heating. A somewhat obvious main conclusion is that the energy saving increases with the electrical efficiency of the prime mover. A non-obvious conclusion is that for a particular efficiency of the engine, the savings flatten out as its power is increased beyond a certain value. This value is somewhere around 1 to 1.5 kilowatts for the reasonable range of efficiencies between $10 \%$ and $25 \%$, suggesting that there is no benefit in going to a larger engine-generator system, which presumably, would cost more as well. However, for especially diesel engines, this maximum size is too small to be commercially available at the present in the U S. It is conceivable that this might make a system like a fuel cell an attractive option, although this has not been evaluated in this project. The results in figure 24 were obtained assuming a 'thermal storage capacity' equivalent to 75,000 Btu and with no electrical storage, that is, no ability to send power back to the utility grid. Further calculations showed that the primary energy savings were not very sensitive to the thermal storage capacity.

Calculations were done assuming the ability to supply power back to the utility grid when there was excess electrical power available. The results are summarized in Figure 25 below for combined space-heating/DHW systems Most of the reverse-metered electric energy was sent back to the grid in the cold months (November through March), when most U.S. electric utilities have little or no need for excess generating capacity. However, the primary energy savings increase with the electrical capacity of the micro-CHP system with the higher electrical efficiencies.

The analytical work has also looked at the effect of recharging a hybrid vehicle at the residence at nights with and without reverse metering. This alters to some extent the primary energy savings. The details can be seen in the full report on this work in Appendix A.

A broad conclusion from this work supports the choice of the engine used in the experimental work in terms of its power. Of course, as described above, the engine is made in Germany and there is no diesel engine of this size manufactured in the United States. This is not surprising as there is not a substantial market for diesel engines, unlike for gasoline engines, in this size range. 


\section{HEATING AND DHW ON LONG ISLAND}

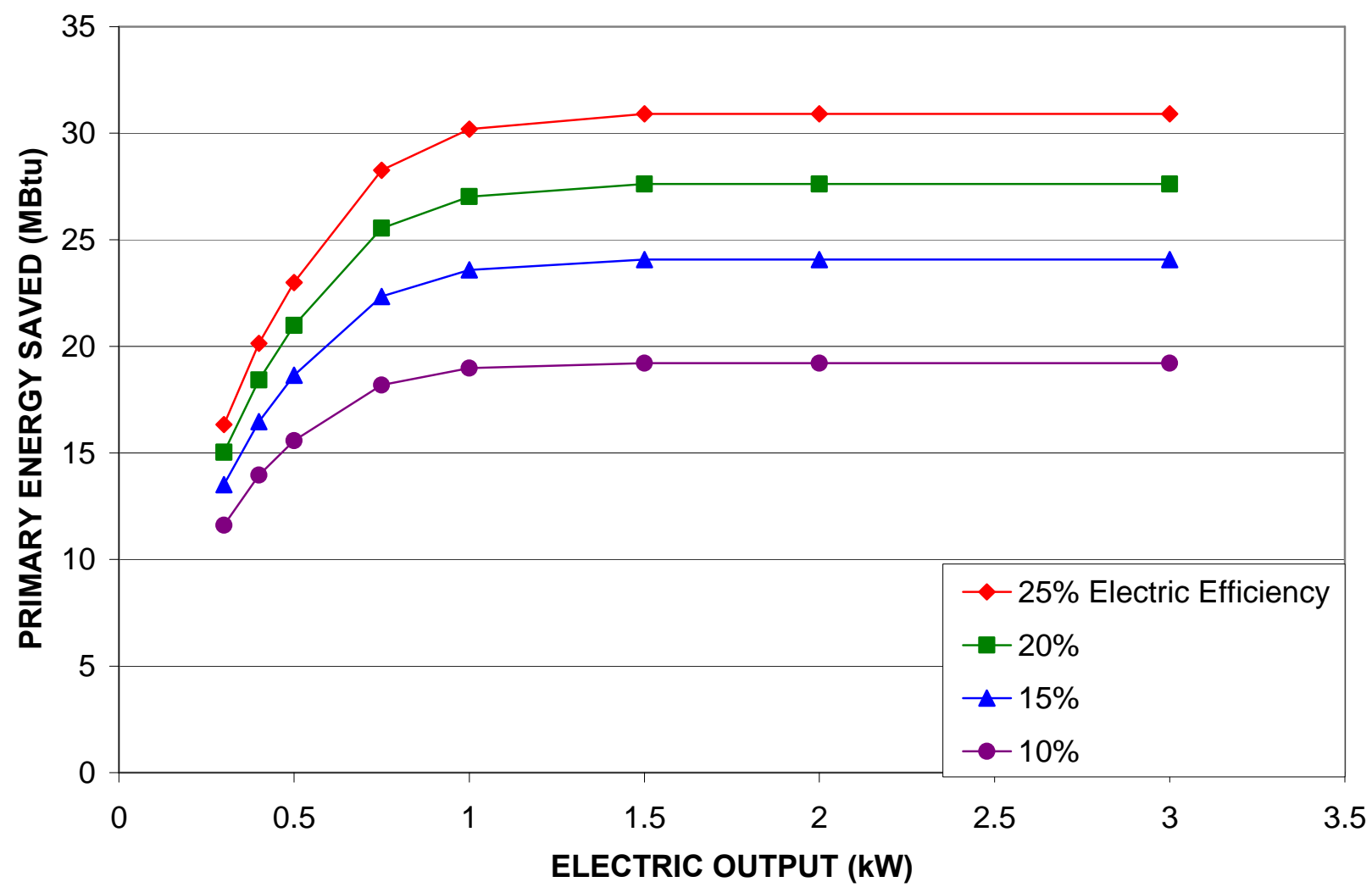

Figure 24. Primary Energy Savings for Combined Space Heat and DHW Systems on Long Island 
HEATING AND DHW ON LONG ISLAND WITH REVERSE METERING

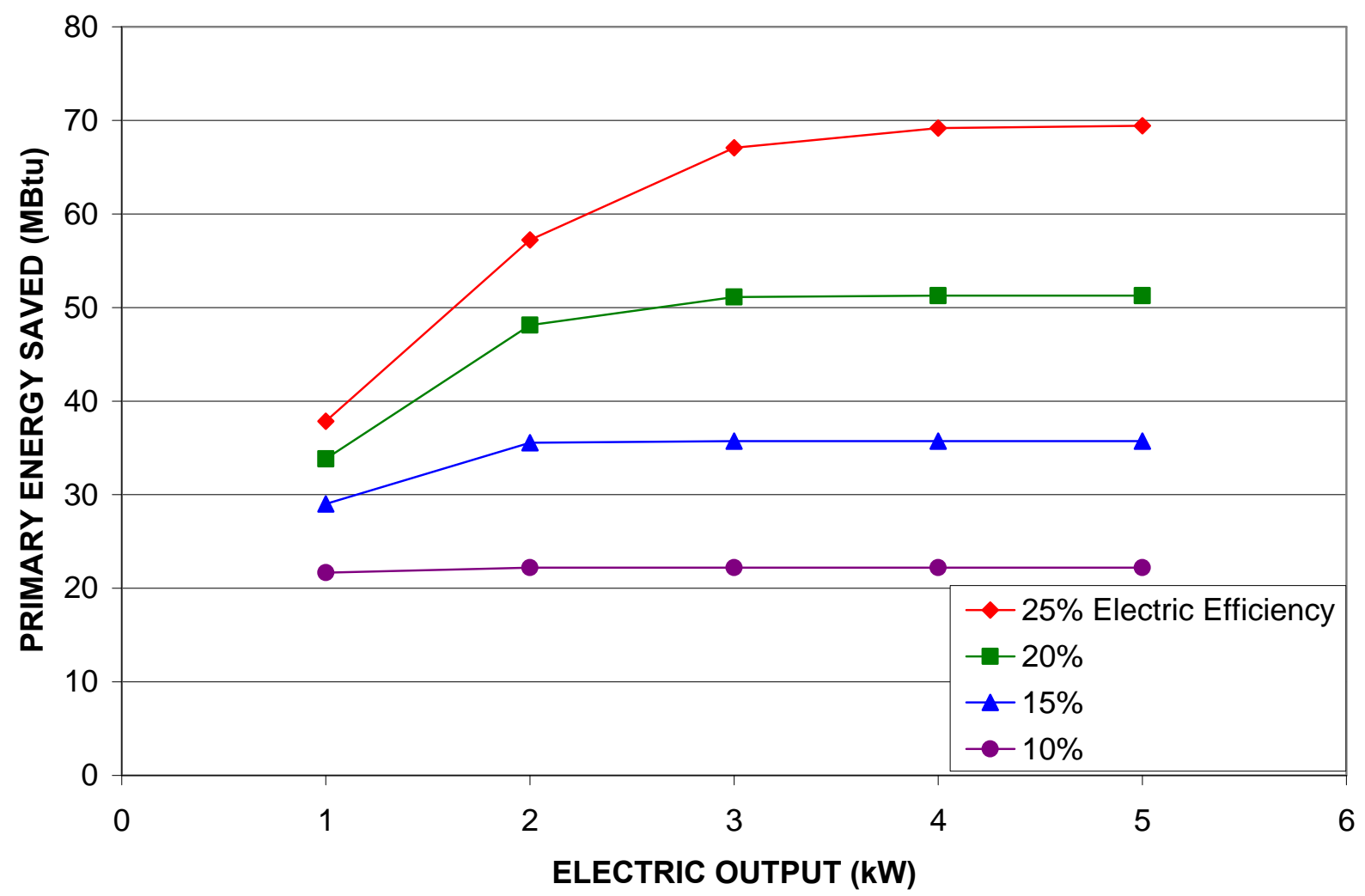

Figure 25. Primary energy savings for space-heating/DHW systems with reverse metering on Long Island

\section{$\underline{5.0 \text { Discussion }}$}

The idea of developing a micro-CHP system based on a small diesel engine was explored in this work. The use of a diesel engine opens up the possibility of using biodiesel as a renewable fuel with the attendant benefits. A key part of the work was to examine the possibility of HCCI operation and this was shown to be possible with both ULSD and biodiesel as fuels with the Econox atomizer being used to inject the fuel into the engine intake. The analytical work modeled the use of such a system in two New York locations, Long Island and Albany and showed that an engine of roughly the size tested would be reasonable for these locations from the point of view of using the energy effectively.

The engine test results showed that in normal engine mode operation, the smoke levels in the exhaust are lower with biodiesel than with ULSD. This is in accord with the observation in the literature that smoke and particulate levels are lower with biodiesel. With NOx emissions, the picture as developed here is somewhat more complex. It is generally stated in the literature that the NOx levels increase with the addition of biodiesel, although of late, there has been some confusion with regard to this. As most of the reported work deals naturally with engines used in transportation, differences seem to arise due to test cycles used, dynamometer testing or road testing etc. In the present tests, the engine speed was practically constant and the generator load 
was varied independently. Any change in generator efficiency was not accounted for, but its effect is believed to be small. The engine tests were conducted with a series of blends of biodiesel in ULSD and the general statement that NOx increases with addition of biodiesel is true at all the loads tested. However, when examined more closely (figures 8 through 8.4 above), some interesting observations arise. It seems that there may be a small reduction at a $20 \%$ blend compared to ULSD and then the NOx goes up with increase in biodiesel in the blend. Also, when NOx per watt of power output is considered, the value remains more or less constant with load for ULSD, while there is a significant reduction as the load is increased with biodiesel. This would suggest that the total emission for ULSD is the same for all power outputs, while it is beneficial to operate at high outputs with biodiesel at least in constant speed power generation situations. The reason for this difference in behavior is not obvious from these limited tests especially as similar results have not been previously reported.

A main objective of the project was to test HCCI-type operation of the engine using a heated atomizer made by Econox LLC to inject the fuel in the intake port. This was demonstrated successfully as described above in what is termed here the mixed-mode. However, the performance was comparable to the reports in the literature with similar single cylinder engine operations. As noted above, the main benefit seen was reduction in NOx emissions and this increased with increase in fuel injection through the intake. This was true on unit watt output basis as well and the NOx levels were lower with biodiesel too. This suggests that similar mixedmode operation could be one way of using biodiesel in stationary diesel engines with significant reductions in NOx. The efficiency of operation is reduced somewhat however and there is attendant increase in CO levels as well. The smoke level, at least in the limited tests done, did not change much from the engine mode operation. There was no attempt to optimize the atomizer, the conditions of injection (nozzle temperature, pressure etc.), and the engine operation including the high pressure fuel injection into the cylinder, to determine or achieve the best possible performance in the mixed-mode. Clearly, the potential of such operation has been demonstrated and significant improvement may be possible. This would have to be done in conjunction with an engine manufacturer. As indicated before, there are no diesel engines of this size manufactured in the U.S., because of the lack of a substantial demand. Broadly speaking, Micro-CHP for residential applications even employing engines more readily available using gasoline, natural gas or propane are not well developed.

\section{Acknowledgements}

Yusuf Celebi provided all the help needed in setting up the engine test facility and in the conduct of the experiments. Our thanks to Bill Scalia of ECONOX LLC for providing their heated nozzle used in the HCCI tests. Dr. Narinder Tutu, a guest scientist (one of the co-authors) helped enormously with the analysis of the experimental data and in the compiling of the report. Finally, we wish to acknowledge NYSERDA for funding the project (PON 1126) and express our thanks to Greg Pedrick for considerate and helpful management of the project. 


\subsection{References}

1. Hua Zhao (Editor). HCCI and CAI engines for the automotive industry, CRC Press, Woodhead Publishing Limited, 2007.

2.Mingfa Yao, Zhaolei Zheng, and Heifeng Liu. Progress and recent trends in homogeneous charge compression ignition (HCCI) engines, Progress in Energy and Combustion Science 35 (2009) 398-437, 2009.

3. Midlam-Mohler, Shawn, Haas, Simon, Guezennec, Yann, Bargende, Michael, Rizzoni, Giorgio, Berner, Hans-Jürgen. Mixed-Mode Diesel HCCI/DI with External Mixture Preparation, FISITA 2004 World Automotive Congress, 2004.

4. Marcello Canova, Shawn Midlam-Mohler, Yann Guezennec and Giorgio Rizzoni. Theoretical and experimental investigation on diesel HCCI combustion with external mixture formation, Int. J. Vehicle Design, Vol .44, No.1, 2007.

5. D. Ganesh, G. Nagarajan, M. Mohamed Ibrahim. Study of performance, combustion and emission characteristics of diesel homogeneous charge compression ignition (HCCI) combustion with external mixture formation, Fuel 87 (2008) 3497-3503, 2008.

6. Ansgar Sommer, Heike Puschmann, Heide Pohland vom Schloß, Klaus Lucka and Heinrich Köhne. Potential of Cool Flame Technology to Realize Premixed, homogeneous Combustion in a Diesel Engine, MTZ 04/2006, Volume 67, 2006.

7. http://www.dstarengineering.com/

8. http://www.ncl.ac.uk/

9. Thomas Butcher and George Wei. Atomization Performance Mapping - Thermal Atomization (Internal Report), Brookhaven National Laboratory, 2007.

10. BNL internal Memorandum, 2009.

11. M. Graboski and R. McCormick, Combustion of Fat and Vegetable Oil Derived Fuels in Diesel Engines, Prog. Energy Combust. Sci., Vol. 24, 1998.

12. Miguel Torres Garcia, Francisco Jose Jimenez-Espadafor Aguilar, Tomas Sanchez Lencero, Experimental study of the performances of a modified diesel engine operating in homogeneous charge compression ignition (HCCI) combustion mode versus the original diesel combustion mode, Energy 34 (2009) 159-171, 2009.

13. ASTM D 2156-09, Standard Test Method for Smoke Density in Flue Gases from Burning Distillate Fuels, 2009.

14. D.W. Dabill, Controlling and monitoring exposure to diesel engine exhaust emissions in noncoal mines, Health and Safety Executive 2004 Research Report 252, 2004.

15. John Andrews, Analytical Studies of Residential scale Micro-Cogeneration Systems, To be published, 2010. 
APPENDIX

\title{
ANALYTICAL STUDIES OF RESIDENTIAL-SCALE MICRO- COGENERATION SYSTEMS
}

\author{
John Andrews
}

May 26, 2010

This report is submitted to Brookhaven National Laboratory Technical Representative Dr. C.R. Krishna in satisfaction of the requirements of Contract 138188.

\begin{abstract}
An analytical study of residential-scale micro-cogeneration systems used hourly electric and thermal loads for a residential building in two New York State locations to quantify the energy savings to be expected relative to a conventional system using heat produced on site and electricity purchased from a utility. Possible ways to improve the impact of micro-cogeneration systems on the electric utility to which they are connected were explored. The principal barrier to widespread application of these systems was identified as the lack of a suitable prime mover having an electric output capacity in the 0.5 to $5 \mathrm{~kW}$ range.
\end{abstract}




\section{INTRODUCTION}

This report describes the results of an analytical study performed for Brookhaven National Laboratory (BNL) in support of a BNL project evaluating alternative options for residential-scale micro-cogeneration systems. The goals of the analysis were threefold:

1. Characterize the available options for prime movers and other subsystems.

2. Quantify the expected primary energy and operating cost savings to be expected from residential-scale micro-cogeneration systems.

3. Analyze system approaches that can provide the best possible interaction with electric utilities in terms of load-curve impacts.

The sections of this report and the goals addressed are summarized in the following table.

\begin{tabular}{|c|c|}
\hline GOAL & REPORT SECTION DESCRIPTION \\
\hline $\begin{array}{l}\text { 1. Characterize the } \\
\text { available options. }\end{array}$ & $\begin{array}{l}\text { Section I. Review of Small-Scale Technology Options. This section } \\
\text { provides background information on the main prime-mover candidates } \\
\text { and system options as found in a search of the literature. }\end{array}$ \\
\hline \multirow[t]{3}{*}{$\begin{array}{l}\text { 2. Quantify the } \\
\text { energy outputs }\end{array}$} & $\begin{array}{l}\text { Section II. Primary Energy Savings Baseline Analysis. This section } \\
\text { performs the analysis of two system types - a "mini-micro" system } \\
\text { designed to produce domestic hot water (DHW), and a larger system } \\
\text { intended to deliver both space heating and DHW. Here it is assumed that } \\
\text { there is no selling of power back to the utility. }\end{array}$ \\
\hline & $\begin{array}{l}\text { Section III. Effect of Thermal Storage and Reverse Metering. This } \\
\text { section expands the assumptions to include the possibility of reverse } \\
\text { metering and also variation in the amount of thermal storage. }\end{array}$ \\
\hline & $\begin{array}{l}\text { Section IV. Impact of Reduced Total Efficiency. This section } \\
\text { addresses the question of what happens to the primary energy savings } \\
\text { when the thermal efficiency is less than optimal. }\end{array}$ \\
\hline \multirow[t]{3}{*}{$\begin{array}{l}\text { 3. Analyze system } \\
\text { approaches }\end{array}$} & $\begin{array}{l}\text { Section V. Hybrid Car Recharging Impacts. One solution to a } \\
\text { potential problem of excessive reverse metering in the colder months is } \\
\text { the use of cogenerated power to charge a plug-in hybrid vehicle. This } \\
\text { might enable a micro-CHP system to operate cost-effectively without } \\
\text { sending power back to the grid. }\end{array}$ \\
\hline & $\begin{array}{l}\text { Section VI. Utility Benefit During Periods of Peak Demand. This } \\
\text { section quantifies the potential economic value to the utility of having a } \\
\text { micro-CHP system available to produce power during peak periods even } \\
\text { if the residence in which it is located does not need the thermal energy. }\end{array}$ \\
\hline & $\begin{array}{l}\text { Section VII. Comparison of Carbon Emissions from Micro- } \\
\text { Cogeneration Systems and Ground-Coupled Heat Pump Systems. } \\
\text { This section continues the theme of utility impacts by comparing the } \\
\text { interactions of a micro-CHP system and a ground-coupled heat pump } \\
\text { with respect to the overall carbon-dioxide emissions. It is found that the } \\
\text { mix of fuel sources used by the utility plays a key role in determining } \\
\text { which system has the smallest "carbon footprint." }\end{array}$ \\
\hline 4. Summary & $\begin{array}{l}\text { Section VIII. Summary Conclusions. The major conclusions of the } \\
\text { report are summarized in a one-page format. }\end{array}$ \\
\hline
\end{tabular}




\section{REVIEW OF SMALL-SCALE COGENERATION SYSTEMS TECHNOLOGY OPTIONS}

A major barrier to the widespread application of residential-scale combined heat and power (micro-CHP) systems has been the lack of a prime mover that would meet all of the following requirements:

- Reliability

- Low maintenance requirements

- Low emissions

- Cost effectiveness

By "prime mover" is meant a device that can input thermal energy from a combustion source and output electrical and thermal energy in forms that are useful in a residential application. If one could assume a "black box" device that met the above criteria, the rest of the system would be a straightforward, albeit non-trivial, exercise in production engineering. Such systems could have many applications, ranging from hot-water-only "mini-micro" systems up to full-blown space heating and cooling systems capable of producing electric power up to $10 \mathrm{~kW}$.

The candidate technologies for the role of prime mover are as follows:

- Internal combustion engine (ICE)

- Fuel cell (FC)

- Stirling engine (SE)

- Small-scale micro-turbine, sometimes called "pico-turbine."

Of the above technologies, only the ICE is beyond the test and evaluation stage and ready for full production. Unfortunately, ICEs require frequent maintenance, and emissions are an issue considering the likelihood of ever-tightening standards. The need for maintenance (which is more difficult to insure in small systems lacking on-site engineering support than in large-scale commercial systems) directly impacts the cost-effectiveness of a system.

Fuel cells and Stirling engines both have significant potential, but they have yet to achieve any significant market penetration. There is no overriding consensus as to when either will be ready for "prime time" or on what the installed costs of such systems will ultimately be.

Pico-turbines have received relatively little attention, and indeed one major report dismisses the turbine category entirely for residential application. There has been, nevertheless, some development in Europe that seems worthy of consideration in the overall picture. 
This section has four parts:

- Summary of a 2005 report issued by the International Energy Agency under Annex 42, the purpose of which was to review the above technology options.

- Review of additional information arising under IEA Annex 42, including the $1^{\text {st }}$ International Conference and Workshop on Micro-Cogeneration Applications, held in Ottawa, Canada in April 2008.

- Review of other information sources.

- Considerations relating to combination and/or competition of micro-CHP systems with other technology options.

\section{IEA Annex 42 Technology Review}

This report, which will be referred to as IEA 2005, considers systems capable of producing up to $10 \mathrm{~kW}$ of electric power and $25 \mathrm{~kW}$ of usable heat. It reviews technologies based on an internal combustion engine (ICE), a fuel cell (FC), or a Stirling engine (SE). It found no turbine-based systems with capacities low enough for residential applications.

The purpose of this section is to provide a useful summary of the information in this report, which is more than 90 pages in length. For further detail, see the Web site which is called out in the reference to IEA 2005.

The usefulness of IEA 2005 lies in the fact that it pulls together information from many sources, and it makes generalizations that can be referenced as benchmarks against which alternative projections may be compared and justified.

It can also be used to get a general idea of the efficiency and emissions characteristics of the different prime movers. However, as these are in a state of flux, the numbers in this report should not be relied on for more than general guidance.

The introductory section of the report calls out the following benchmark efficiencies for cogeneration systems:

Cogeneration (combined heat and power) $\quad>80 \%$

Electricity from the grid $\quad 30 \%-35 \%$

Boilers $\quad 80 \%-95 \%$

In addition, several generic assertions are made in the introduction to this report, which are perhaps worth repeating:

- Cogeneration systems are financially more attractive in periods of high electricity prices and low fuel prices.

- Fuel cells and Stirling engines are promising for the future, but internal combustion engines are the only systems available today at reasonable cost.

- Micro-turbines are less efficient and higher in cost than internal combustion engines in the lower power range, and moreover, for micro-turbines even the low-power range is $30-75 \mathrm{~kW}$, which is too high for residential applications. 
- The major barriers to applications of small-scale systems (relative to larger ones) are: 1) higher cost per kW; 2) perceived low reliability and durability; 3) lack of flexibility with electric grid connection.

- At low loads, electrical efficiency drops significantly except for fuel cell and Stirling engine based cogeneration systems that have better performance for handling partial loads.

- Maximum energy efficiency is reached when the energy delivered equals the energy requirements of the building, but maximum $\mathrm{CO}_{2}$ efficiency may be reached at a higher output.

A benchmark comparison of energy flows in cogeneration vs. conventional heat and power systems is provided in the report and repeated here as Figure 1-1. It should be noted here that the efficiency of electric generation at the power plant is given as 38\%, which is somewhat higher than the $30 \%-35 \%$ quoted earlier in the report. This may be due to the fact that, as the report notes, the efficiency of electric generation at a power plant can be as high as $60 \%$. This would presumably be for state-of-the-art combined cycle processes.

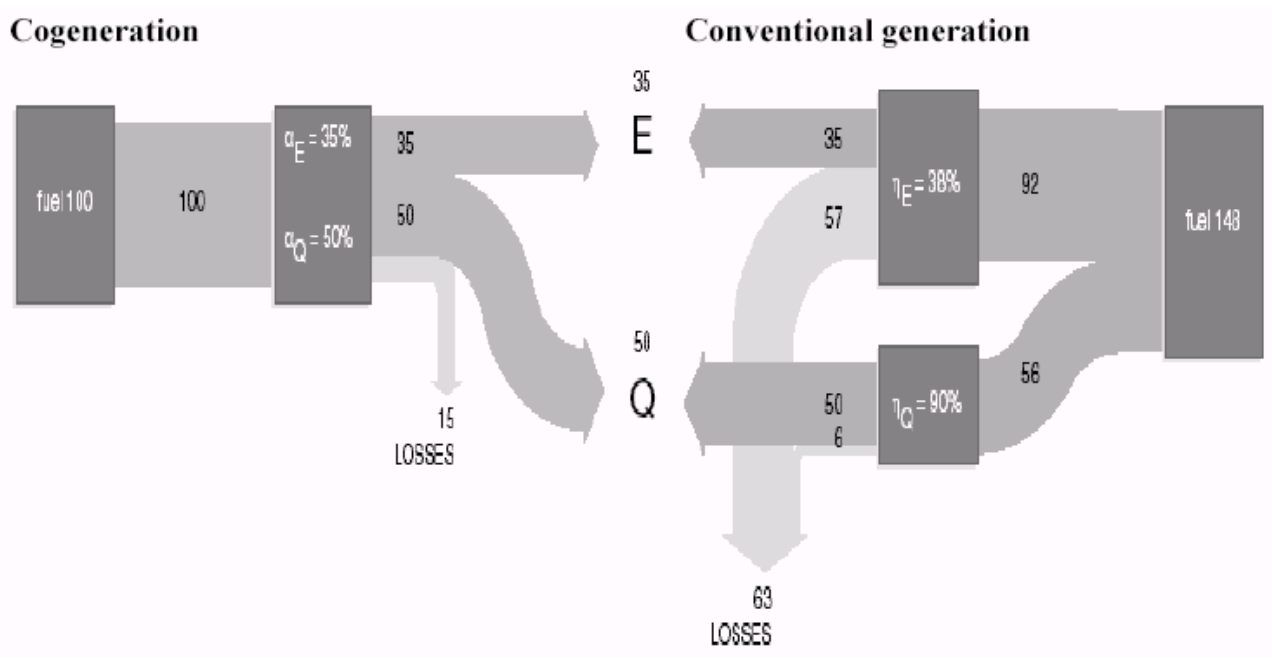

Figure 1-1: Cogeneration versus conventional generation (from IEA 2005)

It may be noted as an aside (to be discussed later) that the attractiveness of cogeneration from the standpoint of primary energy savings depends strongly on the efficiency of the competing electric utility. 


\section{$\underline{\text { Reciprocating Internal Combustion Engine (ICE) Based Cogeneration Systems }}$}

Section 5.1 of IEA 2005 discusses ICE based micro-CHP systems. Heat recovery from these systems can be obtained from three sources: cooling water, exhaust gas, and engine oil. The advantages of ICE based micro-CHP are:

- Proven technology

- Robust nature

- Reliability

- Wide range of sizes from "a few" $\mathrm{kW}$ on up

- A variety of fuels can be used.

However, there is one major drawback:

- ICE systems require frequent and regular maintenance.

ICE systems can be based on Diesel or spark ignition (SI) engines. Diesel engines may use Diesel fuel, heavy oil, or natural gas with a small amount of Diesel pilot fuel. SI engines may run on natural gas, propane, landfill gas, or gasoline. SI engines are often modified versions of Diesel models. The SI counterparts operate at lower brake mean effective pressure and peak pressure, resulting in a power output that is only $60 \%-80 \%$ of the parent Diesel. It was noted that Diesel engines tend to be more available in the larger sizes, whereas SI engines are more available in smaller sizes.

The basic elements of the system are:

- Engine

- Generator

- Heat recovery system

- Exhaust system

- Controls

- Acoustic enclosure

A generic system diagram for an ICE is given in IEA 2005, and repeated as Figure 1-2 below.

Efficiency. Results obtained from a survey of manufacturers indicated that the overall (electric + thermal) efficiencies for ICE based cogeneration systems are in the $85 \%-90 \%$ range, with little variation due to size. Electric efficiency was indicated to be in the $28 \%-39 \%$ range, with higher efficiencies for the larger systems.

IEA 2005 (Figure 4) gave the following benchmark values for power output as a percentage of fuel input under part-load conditions:

\begin{tabular}{|l|l|l|l|l|l|l|l|l|l|}
\hline \% Load & 0 & 12.5 & 25 & 37.5 & 50 & 62.5 & 75 & 87.5 & 100 \\
\hline \% Net Work & 0 & 18 & 25 & 31 & 35 & 37 & 37.5 & 38 & 37.5 \\
\hline
\end{tabular}




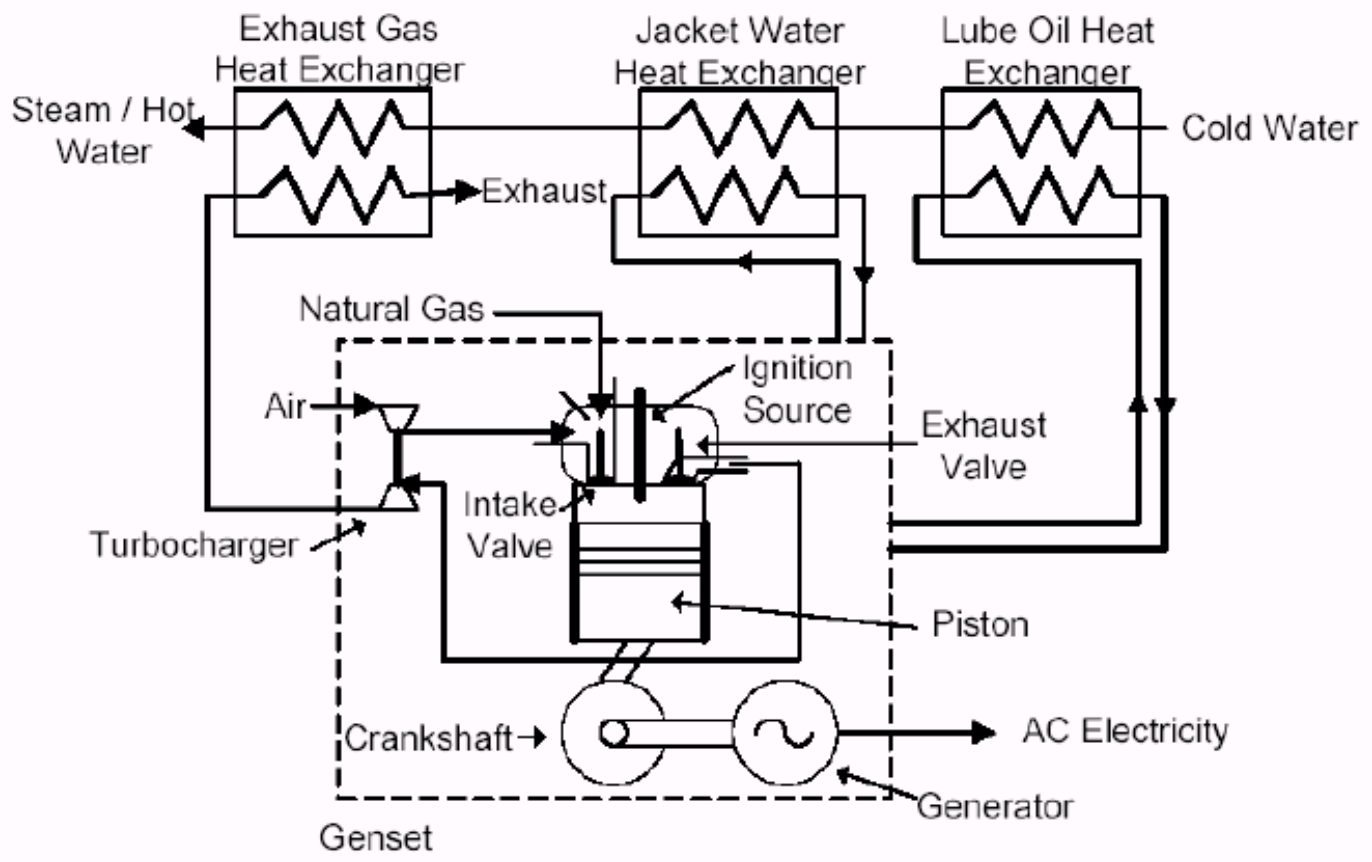

Figure 1-2: Typical packaged internal combustion engine based (spark ignited) cogeneration system (from IEA 2005)

Emissions. IEA 2005 (p. 22) provided the following table of NOx emissions from ICE systems:

\begin{tabular}{|l|l|l|c|}
\hline Engine & Fuel & NOx (ppmv) & NOx (g/MWh)* \\
\hline Diesel (high and medium speed) & Distillate & $430-1350$ & $7000-18000$ \\
\hline Diesel (high and medium speed) & Heavy Oil & $900-1800$ & $12000-20000$ \\
\hline Lean Burn Spark Ignition & Natural Gas & $45-150$ & $700-2500$ \\
\hline
\end{tabular}

* IEA 2005 reported $\mathrm{g} / \mathrm{kWh}$. This was multiplied by 1000 to get $\mathrm{g} / \mathrm{MWh}$, for ease of comparison with the following table.

Two pages later, IEA 2005 provided the following information on selected systems:

\begin{tabular}{|l|l|l|l|l|}
\hline $\begin{array}{l}\text { System } \\
\text { (Emissions } \\
\begin{array}{c}\text { Control) } \\
\text { Emission (g/MWh) }\end{array}\end{array}$ & $\begin{array}{l}\text { Cummins } \\
7.5 \mathrm{kWe} \\
\text { Diesel (None) }\end{array}$ & $\begin{array}{l}\text { Cummins } \\
16 \mathrm{kWe} \text { Natural } \\
\text { Gas (None) }\end{array}$ & $\begin{array}{l}\text { Cummins } \\
16 \mathrm{kWe} \\
\text { Diesel (None) }\end{array}$ & $\begin{array}{l}\text { Coaster Intelligen } \\
55 \mathrm{kWe} \text { Nat. Gas } \\
\text { (Catalytic converter) }\end{array}$ \\
\hline NOx & 1300 & 810 & 1300 & $<20$ \\
\hline $\mathrm{CO}$ & 320 & 3810 & 320 & $<60$ \\
\hline HC & 170 & 130 & 170 & $<20$ \\
\hline Particulates & No data, but 2 larger Diesels w/o emissions control gave 60 g/MWh \\
\hline
\end{tabular}

The NOx emissions for the Cummins Diesels are below the ranges given in the preceding table. (The Coaster Intelligen system, of course, should not be compared because it has emissions control.) 
Maintenance: IEA 2005 (p. 21) provides some benchmark maintenance intervals for ICE systems:

- Tuneup (change engine oil, coolant, spark plugs):

$500-2,000$ hours

- Top-end overhaul (cylinder head and turbocharger rebuild)

$12,000-15,000$ hours

- Major overhaul (piston/ring replacement, crankshaft bearings and seals)

$24,000-30,000$ hours

Maintenance costs from a survey of manufacturers ranged from $\$ 0.005$ to $\$ 0.032$ per kWhe, with the higher costs associated with smaller systems. A survey of demonstration projects in the United Kingdom yielded an average maintenance cost of $\$ 0.014$ per $\mathrm{kWhe}$.

Installed Cost: IEA 2005 provides benchmark numbers for first cost for small systems. Overall, a cost range of $\$ 800$ to $\$ 3,020$ per kWe was quoted, with prices varying inversely with system size. A table of specific systems was provided to give some benchmark numbers:

\begin{tabular}{|l|l|l|l|l|l|}
\hline System Capacity $(\mathrm{kWe})$ & 5.5 & $7.1-10.7$ & $20.1-23.3$ & $30.5-35.0$ & 100 \\
\hline First Cost $(\$ / \mathrm{kWe})$ & $\$ 3020$ & $\$ 2800$ & $\$ 1600$ & $\$ 1300$ & $\$ 1080$ \\
\hline Electric efficiency & $27 \%$ & $28.1 \%$ & $37.4 \%$ & $33.1 \%$ & $30.6 \%$ \\
\hline Thermal efficiency & $61 \%$ & $56.5 \%$ & $50.0 \%$ & $51.2 \%$ & $50.4 \%$ \\
\hline
\end{tabular}

\section{$\underline{\text { Fuel Cell Based Cogeneration Systems }}$}

Section 5.2 of IEA 2005 discusses micro-CHP systems based on fuel cells. Six types of fuel cells are listed; however only two are considered viable candidates for use in micro-CHP systems. These are:

- Polymer electrolyte membrane fuel cell (PEMFC)

- Solid oxide fuel cell (SOFC)

An alternative name for the polymer electrolyte membrane fuel cell is the proton exchange membrane fuel cell. Both names have the same acronym.

Fuel-cell based micro-CHP systems are expected to achieve electric efficiencies in the $30 \%$ $60 \%$ range, with overall efficiencies of $70 \%-90 \%$. It is stated that efficiency differences between systems are due in part to the different fuels used - some use an available fuel while others must use a preprocessed fuel.

It is stated that fuel cell systems have excellent load-following characteristics. A comparison is given between a $200 \mathrm{kWe}$ phosphoric acid fuel cell (PAFC), which is not one of the types that are seen as promising for downsizing for residential applications, and a typical lean-burn engine in the 0.5 to $3.0 \mathrm{MWe}$ range. The implication is that these characteristics, given for larger systems, would also apply to residential-scale systems. The part load efficiencies of the two examples are as follows:

\begin{tabular}{|l|l|l|l|l|l|l|l|l|}
\hline $\begin{array}{c}\text { Load Percent } \\
\text { System Type }\end{array}$ & 30 & 40 & 50 & 60 & 70 & 80 & 90 & 100 \\
\hline PAFC 200 kWe & $32.5 \%$ & $35 \%$ & $36 \%$ & $37 \%$ & $37 \%$ & $37 \%$ & $37 \%$ & $36.5 \%$ \\
\hline
\end{tabular}


Emissions: Emissions for three examples of fuel-cell based systems were presented as follows. It should be noted that two of the three systems are much larger than residential size.

\begin{tabular}{|l|l|l|l|}
\hline Fuel Cell Type & PEMFC & PEMFC & SOFC \\
\hline Output (kWe) & 10 & 200 & 100 \\
\hline Electric Efficiency & $30 \%$ & $35 \%$ & $45 \%$ \\
\hline NOx (ppmv) & 1.8 & 1.8 & 2.0 \\
\hline NOx (g/MWh) & 27 & 27 & 23 \\
\hline $\mathrm{CO}(\mathrm{g} / \mathrm{MWh})$ & 32 & 32 & 18 \\
\hline Unburned HC $(\mathrm{g} / \mathrm{MWh})$ & 5 & 5 & 5 \\
\hline $\mathrm{CO}_{2}(\mathrm{~g} / \mathrm{MWh})$ & 617,000 & 531,000 & 413,000 \\
\hline
\end{tabular}

Capital Costs: Since fuel-cell systems are still in the development stage, no definitive data on costs could be provided. A list of factors influencing cost was, however, provided:

- Stack Subsystem (Fuel cell stack, feed gas manifolds, power takeoffs)

- Fuel Processing Subsystem (Fuel management controls, reformer, steam generators, shift reactors, sulfur absorbent beds, etc.)

- Power Electronics (Solid state boost regulator, DC-AC inverter, grid interconnect switching, load management and distribution hardware, inverter controller, overall supervisory controller)

- Thermal Management Subsystem (Stack cooling subsystem, heat recovery and condensing heat exchangers)

- Ancillary Subsystems (Air supply blowers, water treatment, safety, etc.)

Although installed costs were not addressed, the report did provide an estimate for operation and maintenance (O\&M) costs of $\$ 0.033 / \mathrm{kWhe}$ for the $10 \mathrm{kWe}$ system and $\$ 0.023 / \mathrm{kWhe}$ for the 100 and $200 \mathrm{kWe}$ systems.

Current Manufacturers: IEA2005 provided a list of companies currently manufacturing systems with electrical outputs of $5 \mathrm{~kW}$ or less. In most cases, these are offered as complete micro-CHP systems; where this is not the case, that is indicated in the table on the following page. It should be noted that the efficiencies are sometimes quoted as percentages of the lower heating value (LHV) and sometimes of the higher heating value (HHV) of the fuel. Often the information as to which standard has been used is absent.

Since this report is almost four years old, it is to be expected that some of these may have dropped out while others may have come into the field. 
Manufacturers of Fuel Cell Based Systems as of 2005

\begin{tabular}{|c|c|c|c|c|c|c|c|c|}
\hline \multirow{2}{*}{$\begin{array}{l}\text { Name of } \\
\text { Manufacturer. }\end{array}$} & \multirow[t]{2}{*}{ Country } & \multirow{2}{*}{$\begin{array}{l}\text { Cell } \\
\text { Type }\end{array}$} & \multirow{2}{*}{$\begin{array}{l}\text { Com- } \\
\text { plete } \\
\text { Syst.? }\end{array}$} & \multirow{2}{*}{$\begin{array}{l}\text { Capacity } \\
\text { Range } \\
(\mathrm{kWe})\end{array}$} & \multicolumn{3}{|c|}{ Efficiencies (Percents) } & \multirow[t]{2}{*}{ Fuel* $^{*}$} \\
\hline & & & & & Electric & Thermal & Overall & \\
\hline Acumetrics & USA & SOFC & Yes & $2-100$ & $40-50$ & & 75 & $\mathrm{HC}$ \\
\hline Arcotronics & Italy & & Yes & $2.5-10$ & 40 & 24 & & $\mathrm{H}_{2}$ \\
\hline Reli-On** & USA & & No & 1 & $36-40$ & & & $\mathrm{H}_{2}$ \\
\hline Axane & France & PEMFC & No & $0.5-10$ & & & & $\mathrm{H}_{2}$ \\
\hline Ballard & Canada & PEMFC & Yes & 1 & 55 & & 90 & $\mathrm{NG}$ \\
\hline Ceramic FC & Australia & SOFC & Yes & 1 & 40 & & 80 & $\mathrm{H}_{2}$ \\
\hline European FC & Germany & PEMFC & Yes & 1.5 & 20 & & 80 & $\mathrm{NG}$ \\
\hline FC Technol. & Canada & SOFC & Yes & $2-4.5$ & & & 80 & $\mathrm{HC}$ \\
\hline Fuji Electric & Japan & PEMFC & No & 1 & 38 & & & $\mathrm{NG}$ \\
\hline Hydrogenics & Canada & PEMFC & Yes & 0.5 & & & 80 & $\mathrm{H}_{2}$ \\
\hline IdaTech & USA & PEMFC & Yes & 4.6 & & & & $\mathrm{NG}$ \\
\hline IHI & Japan & PEMFC & Yes & 5 & 35 & & 75 & $\mathrm{NG}$ \\
\hline $\begin{array}{l}\text { Matsushita/ } \\
\text { Panasonic }\end{array}$ & Japan & PEMFC & Yes & 1 & 32 & 42 & 74 & $\mathrm{NG}$ \\
\hline MiniHydrogen & Denmark & PEMFC & No & 1 & & & & $\mathrm{H}_{2}$ \\
\hline Nuvera & USA & PEMFC & Yes & 3.7 & 31.5 & & 80 & $\mathrm{NG}$ \\
\hline Osaka Gas & Japan & PEMFC & Yes & $0.2-0.5$ & $28-31.5$ & $25.5-31.5$ & & $\mathrm{NG}$ \\
\hline Plug Power & USA & PEMFC & Yes & 5 & & & & $\mathrm{NG}$ \\
\hline Proton Motor & Germany & PEMFC & Yes & 5 & 43 & & & $\mathrm{H}_{2}$ \\
\hline Sigen & UK & PEMFC & $\mathrm{No}$ & 1 as DC & $36-40$ & & & $\mathrm{H}_{2}$ \\
\hline SulzerHexis & Swiss & SOFC & Yes & 1 & $25-30$ & & 85 & $\mathrm{NG}$ \\
\hline Vaillant & Germany & PEMFC & Yes & $1-4.6$ & $>35$ & & $>80$ & $\mathrm{NG}$ \\
\hline
\end{tabular}

*Fuels: $\mathrm{NG}=$ Natural Gas, $\mathrm{HC}=$ Light Hydrocarbons, $\mathrm{H}_{2}=$ Hydrogen $* *$ Formerly Avista Labs

\section{$\underline{\text { Stirling Engine Based Micro-CHP Systems }}$}

The Stirling engine concept is not new. The original patent was issued to Robert Stirling in 1816. Stirling engines were widely used in the $19^{\text {th }}$ century, particularly in shipboard applications, but were edged out by internal combustion engines, largely because of the decreasing cost of petroleum fuels in the first half of the $20^{\text {th }}$ century.

The Stirling engine differs from the ICE in that combustion takes place external to the machine. The heat of combustion is introduced into the machine by any of various means, and similarly the waste heat required by the Second Law of Thermodynamics is rejected in another part of the engine. A key element of the Stirling engine is a regenerative heat exchanger, which alternately warms cool working fluid coming from the low-pressure side of the cycle and cools warm working fluid coming from the high-pressure side.

Stirling engines can be either of two types: kinematic and free-piston. In kinematic Stirling engines, power is delivered to the load by means of connecting rods and a crankshaft, as in most internal-combustion engines. The free-piston Stirling engine, for which the first patent was granted in the 1970's, encloses the piston in a hermetic casing and transmits power to the outside 
either by means of a magnetic-mechanical coupling or by using the piston as the moving element in a linear alternator, generating electric power directly instead of using a rotating mechanical device as an intermediary.

Stirling engines come in three generic configurations, designated alpha, beta, and gamma. The alpha design has two pistons. The beta and gamma designs have one piston, but they require the use of a "floating" internal piston called a displacer. Unlike an ordinary piston (whether free or kinematic) the displacer does not transmit work from or to the engine but serves the purpose of moving the working fluid through the regenerator. Schematic representations of the three plans are given in IEA 2005 and reproduced in Figure 1-3 below.

IEA 2005 is very positive about the potential of the free-piston Stirling engine for micro-CHP applications. The biggest advantage is that, because the moving parts are hermetically sealed inside the casing, there are no seals to wear out or to leak working fluid. The following is a list of advantages called out for the free-piston design in IEA 2005:

- No mechanical contact, friction, or wear of moving parts

- Tight sealing of the casing, allowing maintenance-free operation for 10 years

- Versatility of energy input and output

- Quiet operation

- Essentially zero wear

- Zero maintenance over long periods of time

- Long life

- Easy interface with the electric grid

- Continuous power

- Potential for high efficiency

Efficiency and Part-Load Operation. The Stirling cycle is seen as having the potential for higher efficiency than Rankine or Joule cycles because it is closer to the Carnot cycle. Electric efficiency is now $\sim 40 \%$, with $50 \%$ efficiency expected in the future. Overall efficiencies of $65 \%$ to $85 \%$ are expected, with power-to-heat ratios in the $1.2-1.7$ range.

Part-load operation is discussed in the same section of the report (page 62). Here it is stated that while efficiency under full load would be $35 \%-50 \%$, the same engine at half load would have an efficiency in the $34 \%-39 \%$ range.

In the next section on heat recovery, IEA 2005 cites the Solo Stirling $161 \mathrm{CHP}$ unit as having an electrical power output of $2-9.5 \mathrm{~kW}$ and thermal output of $8-26 \mathrm{~kW}$. Electrical efficiency is quoted as being in the $22 \%-24 \%$ range. Overall efficiency as high as $92 \%$ is quoted, based on HHV. A Sunpower biomass-fired unit is also discussed, to generate $4 \mathrm{~kW}$ of heat for each $1 \mathrm{~kW}$ of electricity, and with an electrical efficiency of $12 \%-17 \%$.

Maintenance. Maintenance intervals for kinematic Stirling engines are quoted as being between 5000 and 8000 hours of operation. The free-piston version is expected to be maintenance-free for 10 years. 


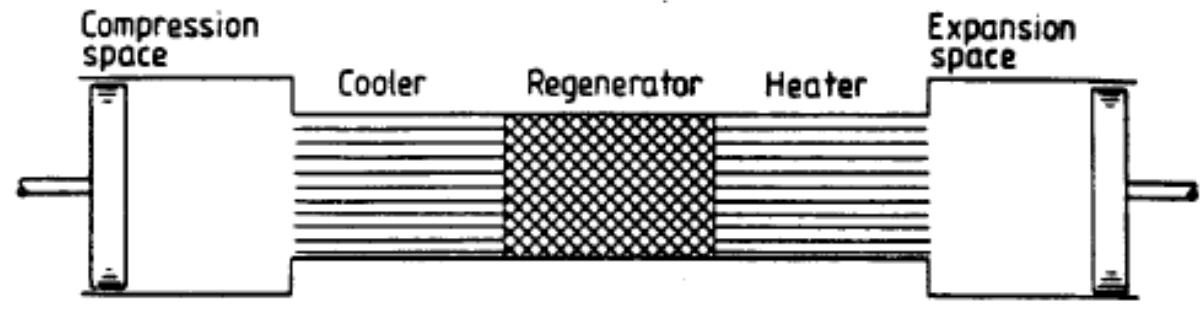

(a) Alpha engine

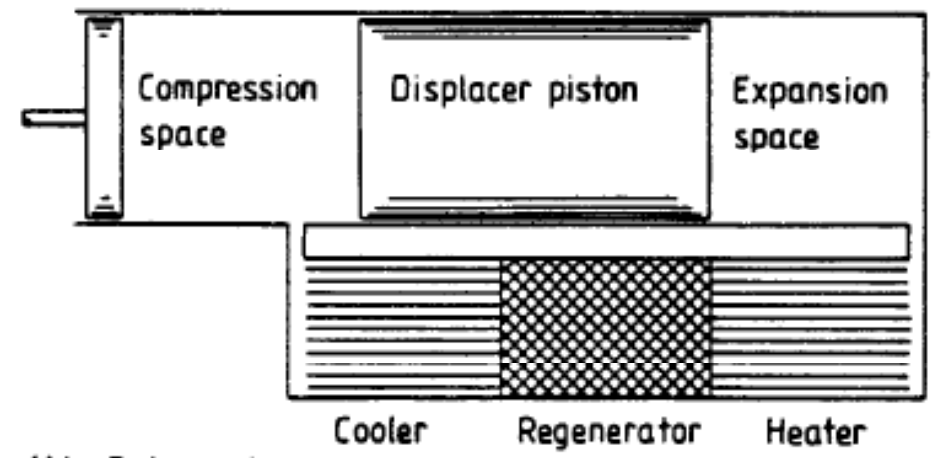

(b) Beta engine

Cooler Regenerator Heater

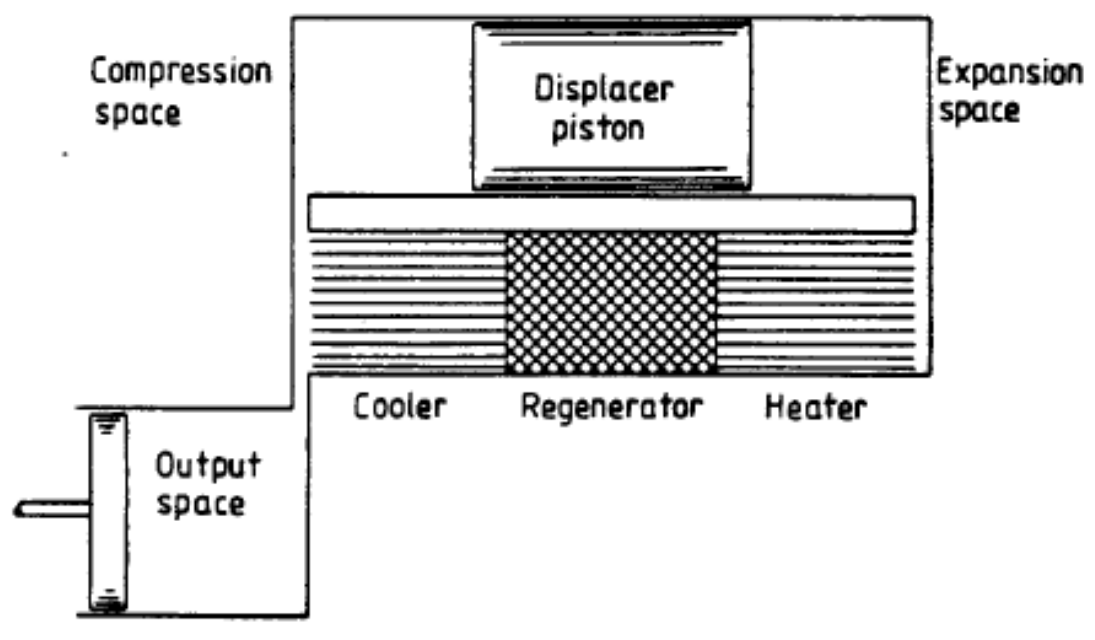

(c) Gamma engine

Figure 1-3. Stirling engine configurations (from IEA 2005).

Emissions. IEA 2005 states that emissions from Stirling engines are comparable to those for modern gas burner technology (not surprising, perhaps, since combustion is external to the machine) and much lower than for the Otto cycle. Numbers for emissions are quoted in grams per brake horsepower hour (g/bhp-hr). For comparison with the tables on ICE and Stirling 
engines, the values are also given here in grams per megawatt-hour (g/MWh). The conversion factor used is $1 \mathrm{~g} / \mathrm{bhp}-\mathrm{hr}=1340 \mathrm{~g} / \mathrm{MWh}$, which is based on $1 \mathrm{hp}=746 \mathrm{~W}$.

\begin{tabular}{|l|l|l|}
\hline \multicolumn{1}{|c|}{ Manufacturer } & \multicolumn{1}{c|}{ Solo } & \multicolumn{1}{c|}{ DTE Energy } \\
\hline Electric capacity $(\mathrm{kW})$ & $2-9$ & $20-25$ \\
\hline Electric efficiency & $22 \%-24 \%$ & $29.6 \%$ \\
\hline Overall efficiency & $>90 \%$ & $82 \%$ \\
\hline NOx (g/bhp-hr) & $0.08-0.12$ & $0.15-0.29$ \\
\hline NOx (g/MWh) & $110-160$ & $200-390$ \\
\hline CO (g/bhp-hr) & $0.04-0.06$ & 0.32 \\
\hline CO (g/MWh) & $50-80$ & 430 \\
\hline
\end{tabular}

Costs. As with fuel cell systems, only very preliminary information could be given about costs. IEA 2005 discusses the Solo unit described in the above table. In addition to providing $2-9 \mathrm{~kW}$ of electricity, it has a thermal output of $8-26 \mathrm{~kW}$. The maintenance interval is given as 5,000 hours. The 2001 cost was quoted at $\$ 13,000$, of which $\$ 10,400$ is for the engine and $\$ 2,600$ for auxiliaries and technical interconnection. Maintenance cost was quoted as $\$ 0.013$ per $\mathrm{kWh}$.

In general, it was stated that first cost tends to be about twice that for an ICE system. The maintenance cost of $\$ 0.013 / \mathrm{kWh}$ was stated to be lower than ICE systems, which was given here as $\$ 0.018 / \mathrm{kWh}$. IEA 2005 estimates that the maintenance cost for Stirling engine based micro-CHP systems will drop to $\$ 0.0065 / \mathrm{kWh}$.

Current Manufacturers. Fewer firms were listed as manufacturing Stirling engine based systems than was the case for fuel-cell based systems. The following were cited as providing systems with electric capacities in the residential range, i.e., $<10 \mathrm{kWe}$.

Manufacturers of Stirling Engine Based Systems as of 2005

\begin{tabular}{|c|c|c|c|c|c|c|}
\hline \multirow[t]{2}{*}{$\begin{array}{l}\text { Manu- } \\
\text { facturer }\end{array}$} & \multirow[t]{2}{*}{ Country } & \multirow[t]{2}{*}{$\begin{array}{l}\text { Engine } \\
\text { Type }\end{array}$} & \multirow{2}{*}{$\begin{array}{l}\text { Capacity } \\
\text { Range } \\
(\mathrm{kWe})\end{array}$} & \multicolumn{2}{|c|}{$\begin{array}{l}\text { Efficiencies } \\
\text { (Percents) }\end{array}$} & \multirow[t]{2}{*}{ Fuel* } \\
\hline & & & & Electric & Overall & \\
\hline Microgen & UK & $\mathrm{FP} * *$ & 1.1 & 28 & 90 & NG \\
\hline Solo & Germany & Alpha & $2-9.5$ & $22-24$ & $92-96$ & $\mathrm{HC}$ \\
\hline STC & USA & $\mathrm{FP}$ & $0.06-3$ & $\begin{array}{l}23- \\
35\end{array}$ & & \\
\hline Enatec & $\begin{array}{l}\text { Nether- } \\
\text { lands }\end{array}$ & FP & $0.6-1.0$ & 25 & & \\
\hline Sunpower & US & $\begin{array}{l}\text { Origina } \\
\text { Sunpow } \\
\text { system, }\end{array}$ & $\begin{array}{l}\text { of of the fi } \\
\text { does no } \\
\text { ut license }\end{array}$ & $\begin{array}{l}\text { e-piston } \\
\text { manufac } \\
\text { to other }\end{array}$ & $\begin{array}{l}\text { Stirling eng } \\
\text { ure its own }\end{array}$ & ro-CHP \\
\hline $\begin{array}{l}\text { Whisper } \\
\text { Tech }\end{array}$ & $\begin{array}{l}\text { New } \\
\text { Zealand }\end{array}$ & Alpha & $\begin{array}{l}0.85- \\
1.2\end{array}$ & $\begin{array}{l}11.6- \\
12.6\end{array}$ & $94-96$ & $\begin{array}{l}\mathrm{NG}, \mathrm{HC} \\
\mathrm{K}, \mathrm{D}\end{array}$ \\
\hline
\end{tabular}

$* \mathrm{NG}=$ Natural Gas; $\mathrm{HC}=$ Light Hydrocarbons, $\mathrm{K}=$ Kerosene, $\mathrm{D}=$ Diesel

** FP $=$ Free Piston 


\section{$\underline{1^{\text {st }} \text { International Conference and Workshop on Micro-Cogeneration Applications }}$}

This conference, held in late April 2008 in Ottawa, Canada, was sponsored by IEA Annex 42. Approximately 50 papers were presented. Some of these provided nuggets of information that may be useful in strategizing future development of micro-CHP systems.

An overview paper (Slowe 2008) projected that in 2009, four or five $1 \mathrm{kWe}$ micro-CHP systems would be introduced into markets, with sales of "up to" 10,000 units in 2010. It was also stated that North America is behind Europe in bringing these systems to market.

A simulation study (Dorer and Weber 2008a) compared micro-CHP systems with groundcoupled heat pumps. All the leading prime movers for the micro-CHP systems were included, i.e., internal combustion engine (ICE), polymer electrolyte membrane (aka proton exchange membrane) fuel cell (PEMFC), solid oxide fuel cell (SOFC), and Stirling engine. The salient conclusion was that the savings in primary energy and $\mathrm{CO}_{2}$ emissions of both the micro-CHP syatem and the ground-coupled heat pump depend importantly on the fuel mix and the generation efficiency of the utility from which power is obtained. Ground-coupled heat pumps were found to be strong competitors to micro-CHP systems for both a standard European mix of electric generation technologies and also under the assumption of combined-cycle generation at the utility. In general, as the efficiency of utility power generation increases, the primary energy savings decreases for micro-CHP systems and increases for ground-coupled heat pumps.

A comprehensive review of simulations of micro-CHP system options carried out under IEA Annex 42 was given in a recent journal article by the same authors (Dorer and Weber 2008b). It provided additional information and insights not discussed in their Ottawa paper. For example, they refer to analyses of systems that combined micro-CHP with an on-site solar thermal system. They "confirmed that an overall increase in the contribution of renewable energy to meet energy demands was possible, but also identified conflicts between producing heat in residential cogeneration and with the solar thermal system." They state that when comparing possible control strategies, "[i]n many cases, heat-following modes exhibited the best efficiency for energy, and electricity-following modes for cost, but combined control modes were shown to be the most effective in certain cases." Also, "[t]he efficiencies of an MCHP system under real operating conditions can be considerably lower than those of the MCHP device alone when operating at full load." This paper provides extensive tables and charts showing the various conclusions of their simulations. Assessment of their significance and generality require detailed attention to the assumptions made, which are laid out quite openly in the report.

Coming back to the Ottawa conference, a simulation study of a micro-CHP system in Finland (Alanne 2008) concluded that there would not be much difference in energy cost savings between an optimized $1 \mathrm{kWe}$ micro-CHP system and an optimized $5 \mathrm{kWe}$ system. The $5 \mathrm{kWe}$ system was projected to save $13 \%$ on energy cost, relative to a baseline gas boiler system, while the $1 \mathrm{kWe}$ system saved $10 \%$ relative to the same benchmark. The study assumed a SOFC based system. It was commented that SOFC systems suffer from poor controllability, that is, they don't do well under conditions of rapidly fluctuating demand. This comment should be compared with the statement in IEA 2005 that fuel cell systems perform well under part-load conditions. The two statements are not necessarily in conflict. Performance could be good 
under part loads as long as these loads don't change very rapidly. However, it is commonly reported that fuel cells do like to run at constant loads, and this paper agrees with that generalization. The paper presents some numerical results for the annual energy flows in the systems studied; this could serve as a benchmark for comparisons.

A report (Manning et al. 2008) on the integration and monitoring of micro-CHP systems at the Canadian Centre for Housing Technology described their practical experience in the problems inherent in adapting systems to a particular type of housing that might exist in a given country, especially if the system was originally designed for a markedly different housing stock. "The most important lesson from these installations is that every system is unique and comes with its own set of challenges. Accommodations for electrical generation, thermal storage, heat utilization, and backup heat all need to be carefully designed. Ideally, CHP units need to be designed by the manufacturer to suit the market. Accommodating systems designed for foreign locations often requires substantial modifications that lead to lower efficiency and less-than optimal performance. For a Canadian home, systems need to be sized for ease of installation, be designed for $120 / 240 \mathrm{VAC} 60 \mathrm{~Hz}$ electricity, $1.7 \mathrm{kPa}(0.25 \mathrm{psi})$ natural gas pressure, and for a range of climate conditions. The controls need to be designed to accommodate forced air systems."

Another paper (Kobayashi 2008) reported on experience with 450 PEMFC cogeneration systems in Japan, of which 205 systems provided data for an entire year. These systems were reported to save an average of $10 \mathrm{kWh}$ of primary energy per day, relative to a non-cogeneration system. The paper also indicated the need to avoid startups and shutdowns of the PEMFC as much as possible, since energy is consumed at startup before any output is achieved.

Another paper (Hawkes, Leach, and Brandon 2008) investigated the economic impact of the energy costs of starting up a micro-CHP system from a non-operating condition (which tend to be high with fuel cells, lower with ICE systems) and turndown ratio (the ability of a system to operate at a constant part load. It was found that the economic impacts of startup costs were high for ICE systems, because they typically have high heat-to-power ratios and must therefore switch off more often than systems with low heat-to-power ratios. Turndown ratio was found to significantly influence the case for investment in all micro-CHP technologies. Where a microCHP system was only capable of on/off type operation (i.e. maximum turndown ratio of 1), the case for investment was appreciably worse than with a turndown ratio close to zero.

Tests of three fuel cell based micro-CHP systems were performed at the National Institute of Standards and Technology's fuel cell test facility. (Davis 2008). Maximum output was approximately $5 \mathrm{kWe}$ for each of the three systems. Electrical efficiency was $20 \%$ to $25 \%$ in the 2 to $5 \mathrm{kWe}$ output range. These efficiencies were much less than what fuel cells are supposed to be capable of, and the thermal efficiencies, which ranged from $15 \%$ to $40 \%$, were disappointingly low. The authors rated the performance as too poor for commercial development, but allowed that the potential for technology development is still there.

Tests of the WhisperGen ${ }^{\mathrm{TM}}$ micro-CHP system from New Zealand were performed by a Canadian team. (Lombardi, Ugursal, and Beausoleil-Morrison 2008). This is based on a 
kinematic Stirling engine. The system has been marketed primarily for the marine market up to now. They found steady-state electrical efficiency of $10 \%$ and thermal efficiency of $80 \%$.

\section{Other Information Sources}

In addition to the information arising from IEA Annex 42, a number of other sources may shed additional light on the future potential for micro-CHP systems.

Pico Turbines: A relative newcomer in the small cogeneration business, Micro-Turbine Technology bv (MTT) has been developing a new turbine concept designed to achieve reasonable efficiencies even at small sizes, a market niche in which gas turbines have not been very successful, for the reason that losses from flow leakage, thermal losses, and friction tend to loom larger, as a fraction of energy input, as a machine is downsized. MTT claims to have a design, based on a rotating combustion chamber combined with an efficient compressor, that can overcome these problems. Their Web site, http://www.mtt-eu.com, states that "the power output of the MTT turbine ranges from $100 \mathrm{~W}$ up to $30 \mathrm{~kW}$." It also states that typical installed costs are around $\$ 500$ - $\$ 750$ per $\mathrm{kWe}$, depending on efficiency. According to the Web site, market introduction is expected to be in 2009 , and that the market price will be around 600 euros above the price of condensing boilers.

An email to the company elicited (Ahout 2009) the information that the company's current focus is on the development of a $3 \mathrm{kWe} / 15 \mathrm{kWth}$ micro CHP system, with "an (European) focus on top end domestic / SME market." They now expect that the micro CHP system will be commercial by mid 2012. The apparent time delay "is partly due to development work, extensive certification procedures and field trials that have to be performed." The target price is approximately "Euro 5000 ex VAT (consumer / end user price installed)."

This is a potentially very interesting project as it represents a possible application of microturbines to the residential micro CHP market, something not seen in other technology reviews.

Environmental Protection Agency Outlook. A PowerPoint presentation (Banwell 2006) by a representative of the United States Environmental Protection Agency (EPA) provided information on emerging micro-CHP technologies that were entering the marketplace at the time of his talk. The characteristics of the systems discussed are summarized in the table on the next page.

The presentation also included a discussion of a micro-CHP model used by the EPA. Results of a simulation for Hartford, CT, were presented. These indicated a reduction in purchased electricity of 5,501 kWh per year, an annual net energy cost savings of $\$ 745$, and emissions reductions of $38 \%$ for $\mathrm{CO}_{2}, 94 \%$ for $\mathrm{NOx}$, and $99.9 \%$ for $\mathrm{SO}_{2}$. 
Micro-CHP Systems Entering the Market

\begin{tabular}{|l|l|l|l|l|}
\hline System Identifier & $\begin{array}{l}\text { Japan: Honda } \\
\text { IC Engine }\end{array}$ & $\begin{array}{l}\text { Japan: Tokyo } \\
\text { Gas Fuel Cell }\end{array}$ & $\begin{array}{l}\text { England: } \\
\text { PowerGen/ } \\
\text { WhisperGen }\end{array}$ & $\begin{array}{l}\text { Massachusetts: } \\
\text { Climate Energy } \\
\text { Cogen Unit }\end{array}$ \\
\hline Unit Type & $\begin{array}{l}\text { IC Generator/ } \\
\text { Hot Water/ } \\
\text { Radiant Floor }\end{array}$ & $\begin{array}{l}\text { Fuel Cell } \\
\text { Generator/ } \\
\text { Hot Water }\end{array}$ & $\begin{array}{l}\text { IC/Stirling Engine } \\
\text { Generator and } \\
\text { Boiler }\end{array}$ & $\begin{array}{l}\text { IC Engine/ Hot Air } \\
\text { System (Replaces } \\
\text { Furnace) }\end{array}$ \\
\hline Status of Market & $\begin{array}{l}25,000 \text { currently } \\
\text { operating in } \\
\text { Japan }\end{array}$ & $\begin{array}{l}\text { Plans to test/ } \\
\text { own/maintain } \\
200 \text { units }\end{array}$ & $\begin{array}{l}\text { Commercial sales } \\
\text { since } 2005\end{array}$ & $\begin{array}{l}\text { Testing } 25 \text { units in } \\
\text { households }\end{array}$ \\
\hline Thermal Efficiency & $65 \%$ & $45 \%$ & $70 \%-80 \%$ & $65 \%$ \\
\hline Electrical Efficiency & $20 \%$ & $33 \%$ & $10 \%-20 \%$ & $20 \%$ \\
\hline Combined Efficiency & $85 \%$ & $78 \%$ & $90 \%$ & $85 \%$ \\
\hline Electrical Output & $1 \mathrm{~kW}$ & $1 \mathrm{~kW}$ & $1-1.2 \mathrm{~kW}$ & $1.2 \mathrm{~kW}$ \\
\hline Cost & $\$ 7,500$ in Japan & $\$ 8,500$ in Japan & $\$ 5,500$ & $\$ 10,000-\$ 12,000$ \\
\hline
\end{tabular}

The key drivers that would encourage market penetration of these systems were listed as:

- High local electric rates

- Northerly location with high number of heating degree days

- Reduction in the capital cost of the unit

- Net metering legislation in the state

The presentation concluded with the following bullets:

- Big players in the game

- $1 \mathrm{~kW}$ - international consensus size

- Significant electric savings

- CT/Japan: environmental savings

- Motors are cheaper than fuel cells, but, remember the Prius

American Council for an Energy Efficient Economy Outlook. A 2004 publication of the American Council for an Energy Efficient Economy (ACEEE 2004) made projections concerning the market development of Stirling engine based micro-CHP systems. A key prediction was that costs for these systems would decrease dramatically. It is stated that "[e]arly prototypes for the kinematic Stirling cost $\$ 10,000 / \mathrm{kW}$, but are expected to reach a mature price of $\$ 1,000 / \mathrm{kW}$ by 2006 . Free-piston Stirling engines are currently moiré expensive (Sunpower's $1 \mathrm{~kW}$ prototype cost $\$ 35,000$ ); however, the mature market price is expected to be between $\$ 500$ - \$1,000 per kW." It was also stated that "Sunpower has developed a prototype biomassfired $1 \mathrm{~kW}$ free-piston Stirling engine and expects to have a commercial model ready by 2006." These predictions have, unfortunately, not come true in the time frame indicated.

Their analysis assumed 25\% electricity conversion efficiency and 40\% waste heat recovery for space heating and domestic hot water. They assumed a mature cost of $\$ 1,000$ per $\mathrm{kW}$ and maintenance costs of 3 cents per $\mathrm{kWh}$. 


\section{Combinations and Competition with Other Technology Options}

Comparative analysis of micro-CHP systems with competing systems such as solar thermal, solar photovoltaic, ground-coupled heat pump, or heat activated heat pump, or with hybrid systems that combine micro-CHP with one of these alternatives, is beyond the scope of this report. The author, however, felt that it would be useful to give a very brief sample of such an analysis, which also casts light on one of the issues identified as being of critical importance, namely the attitude of utilities and regulators to reverse metering with micro-CHP systems.

This is contrasted with a more accepting attitude of utilities towards grid-connected photovoltaic (PV) systems in residences. A major reason given for this difference is that PV systems provide more energy in the summer than in the winter, and the summer is when most U.S. utilities need additional power. Micro-CHP systems, by contrast, provide more electric power in the winter, when most utilities already have a surplus of generating capacity.

To begin to get a quantitative idea of the magnitudes involved, the expected useful electrical output from a $1 \mathrm{~kW}$ (peak) PV system on Long Island was obtained from the PV Watts Web site of the National Renewable Energy Laboratory (NREL 2009). Default assumptions specified in the NREL site were used. The total electric energy output from this system over the course of a year was $1195 \mathrm{kWh}$.

In order to obtain a meaningful comparison, it was decided to use a $1 \mathrm{kWe}$ micro-CHP system, operating in a heat following mode with reverse metering, as a baseline. The electrical and thermal efficiencies of the micro-CHP systems used in the comparison were $25 \%$ and $60 \%$, respectively. This system provided $5975 \mathrm{kWh}$ of electricity over the course of the year.

A PV system that could provide the same total amount of electric energy would need to have a peak power of $5 \mathrm{~kW}$. This was determined by scaling up the $1195 \mathrm{kWh}$ provided by a $1 \mathrm{~kW}$ peak system to provide $5975 \mathrm{kWh}$ of electricity, the same as the micro-CHP system. The ratio of 5975 to 1195 is almost exactly 5.0 .

Finally, a $5 \mathrm{~kW}$ micro-CHP system was included in the mix, to see how two systems, the PV and the micro-CHP, each with the same peak power, would compare. The $5 \mathrm{~kW}$ micro-CHP system provided 10,969 $\mathrm{kWh}$ of electricity over the course of the year. (The reason why the micro-CHP output does not scale linearly with peak power is, of course, that it is limited by the thermal load. The PV system has no such limitation.)

The results are shown in Figure 1-4, for a house on Long Island, New York with load characteristics to be described in the next section. The $5 \mathrm{~kW}$ PV system's output does indeed peak in the summer, whereas the $1 \mathrm{~kW}$ micro-CHP peaks in the winter. The winter-to-summer differential is greater for the micro-CHP system than it is for the PV. 
CHP and PV Monthly Electric Outputs -- Long Island

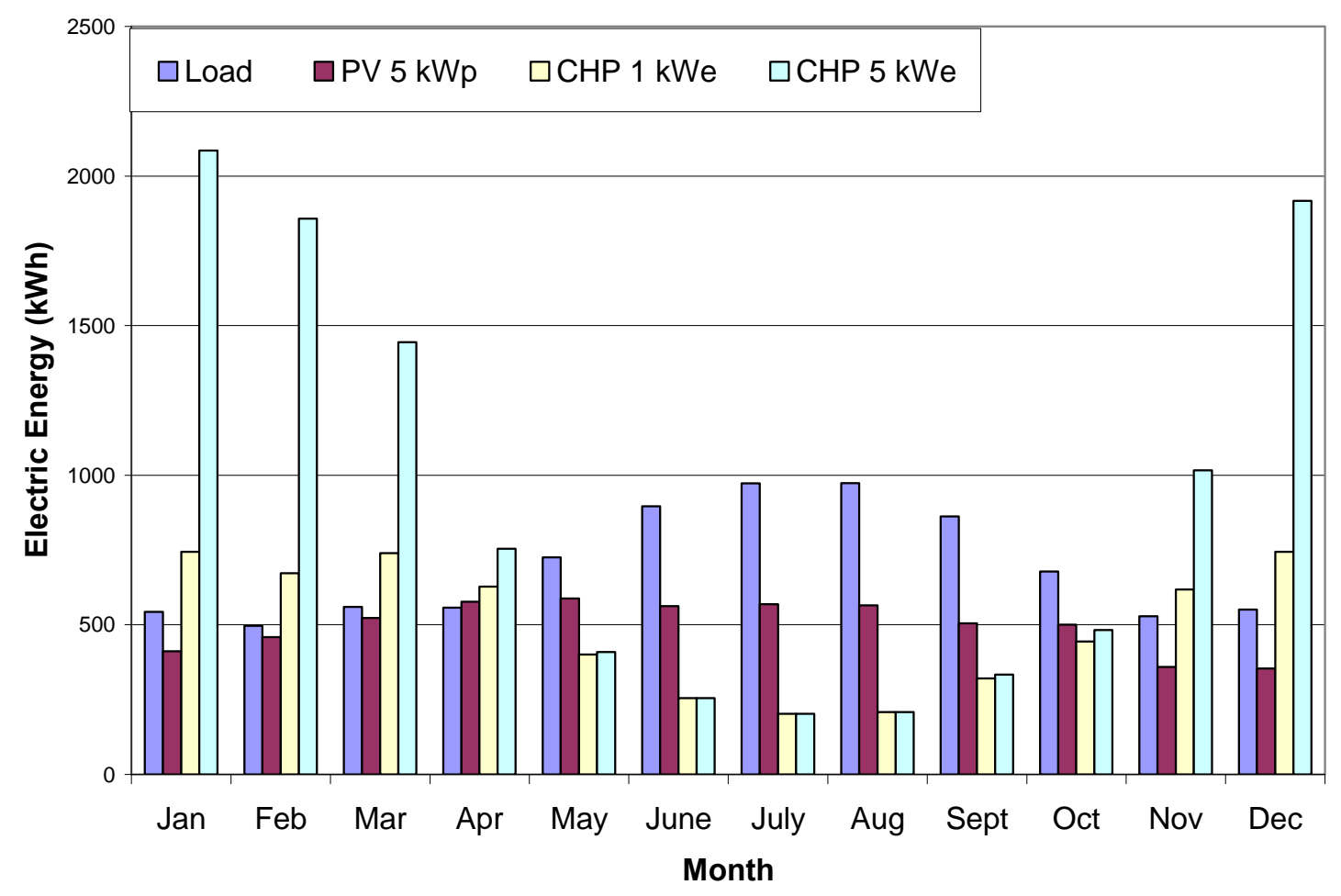

Figure 1-4. Comparison of monthly electrical outputs for PV and micro-CHP systems.

The PV system never delivers more electricity than the house uses in any month, although on an hour-by-hour basis this will not be the case. If a regulatory environment were in place that allowed reverse metering but not negative billing, the PV system would suffer no penalty for excess power delivered. The $1 \mathrm{~kW}$ micro-CHP system delivers more power than the house uses in the five coldest months November through March, and it would suffer a modest penalty under the above scenario.

The extreme case is the $5 \mathrm{kWe}$ micro-CHP system. It delivers no more power in the summer than the $1 \mathrm{kWe}$ system, since both are limited to providing the domestic hot water load. In the winter, however, the $5 \mathrm{kWe}$ system meets essentially all of the thermal load of the house, in the meantime providing electric power far in excess of the house's need.

A chart like this may help to explain why there is an emerging consensus, at least according to the Environmental Protection Agency (Banwell 2006) that the $1 \mathrm{kWe}$ system size is close to optimal for micro-CHP. 


\section{Summary}

As Yogi Berra is reported to have said, "Predictions are hard to make, especially when they're about the future." Of course, not all predictions are dicey. Death, taxes, and the rising of the sun tomorrow morning can be relied on to happen. Unfortunately, the future of micro-CHP is not in this easy-to-predict category.

Chief among the reasons for this is that the micro-CHP technology is still very much under development. The "holy grail" of a reliable, cheap, low-maintenance prime mover that behaves in the system like a worry-free black box is still very much in the future. The lack of such a prime mover is the main obstacle to the widespread dissemination of micro-CHP technology. Certainly this is true in U.S. residential applications.

Of the major contenders - internal combustion engines, fuel cells, and Stirling engines - each has its own characteristics that impact positively or negatively on any projection of its ultimate viability. The internal combustion engine is a proven technology, indeed the only proven technology currently in the running, but its need for frequent maintenance is a drawback in a residential environment in which homeowners frequently neglect their heating systems until they break down. On the other hand, fuel cells and Stirling engines offer promise of reduced maintenance requirements and perhaps improved electrical efficiency as well, but they are still in the development stage. Predictions of when they would be ready for large-scale marketing have more than once proved to be optimistic.

But again, it cannot be emphasized too strongly that a suitable prime mover is the main barrier to the implementation of micro-CHP on a wide scale in the United States.

It is not the only barrier, however. The second problem area is the relationship of the on-site micro-CHP system to the electric utility serving the residence. The impact of policy decisions that either encourage or impede reverse-metering has been widely discussed. Developers of micro-CHP systems find themselves on the horns of a dilemma. Should they conform to restrictions they expect utilities to impose, such as restrictions on the amount of reversemetering, price differentials between power purchased and power sold back, and requirements that the system shut down during periods of utility outage? Or should they give up the benefits of reverse-metering entirely and optimize the system under the constraint of one-way-only access to the grid?

A less often discussed question refers to the generation mix of the utility itself. One might suppose that - as long as the utility can be depended on to supply power to the residence when it is needed and to purchase excess power from the residence when it is available - it should not matter how the utility comes by that power.

Unfortunately that is not the case. Several competing residential energy systems are under development, all of which aim to achieve overall energy efficiencies, primary energy savings, and/or $\mathrm{CO}_{2}$ emissions reductions that exceed what is possible using a condensing boiler or furnace, a high-efficiency water heater, and electric power derived solely from the grid. In addition to competition within the class of micro-CHP systems, based on the type of prime 
mover (internal combustion engine, fuel cell, Stirling engine, or pico turbine), non-CHP options such as ground-coupled heat pumps and fuel-fired heat pumps are also in play. The relative merits of the various system options depend not only on the technical and economic characteristics of the systems themselves but also on the characteristics of the systems used by the utility to generate the electric power that it sells.

Salient among the insights discussed in this regard is the question of micro-CHP versus groundcoupled heat pump. The IEA work under Annex 42 has indicated that the greater the efficiency and the lower the emissions of the power plants on which the utility depends, the better it is for the ground-coupled heat pump in its competition with all micro-CHP systems. Conversely, if the local electric utility is going to be tied to relatively inefficient, high-emissions power sources such as conventional coal-fired generation, the better it is for the micro-CHP system.

The reason is easy to understand. Micro-CHP systems sell power to the utility. Their relative advantage is proportional to the extent to which the efficiency at which they generate power (or the carbon emissions they produce) is an improvement over the efficiency (or carbon emissions) at which the utility would generate the same power. Thus, the benefit of micro-CHP is less if the utility depends mostly on high-efficiency combined-cycle systems than if it is tied to out-of-date $33 \%$-efficient fossil-fueled units. In contrast, ground-coupled heat pumps amplify electric power to make heat, which implies that they must take the efficiency (or carbon emissions) of generation as the first factor in a multiplicative series that determines their ultimate merit.

A ground-coupled heat pump with a seasonal average coefficient of performance (COP) of, say, 3.0 will not look much better than a condensing furnace or boiler if the electricity is generated at $33 \%$ efficiency, but if that efficiency is $50 \%$, the ground-coupled heat pump now has an overall primary-energy efficiency of $150 \%$. In contrast, a micro-CHP system that generates heat and electricity at $85 \%$ efficiency gains 52 percentage points against $33 \%$-efficient utility power, but only 35 percentage points against $50 \%$-efficient utility power.

The only micro-CHP systems available today at reasonable cost use internal combustion engines as their prime movers. Promising emerging technologies for the role of prime mover include the free-piston Stirling engine, the polymer electrolyte membrane fuel cell (PEMFC) and the solid oxide fuel cell (SOFC). A "dark horse" contender is a microturbine designed to mitigate the high percentage losses usually encountered in small-scale gas turbine designs.

Systems with high heat-to-power ratios, such as most ICE systems, are much more cost-effective if they can be run at low fractions of full power, and if the costs of starting up from a nonoperating condition are low. Fuel cells and Stirling engines are less sensitive to these parameters because they typically have high heat-to-power ratios.

Finally, it should be reiterated that, throughout this report, examples were given of micro-CHP systems with electrical efficiencies considerably lower than what their prime movers are ideally capable of. The extent to which this gap can be narrowed in marketable systems remains to be seen. 


\section{$\underline{\text { Section I References }}$}

ACEEE 2004. "Emerging Technologies and Practices 2004." American Council for an Energy Efficient Economy, Washington, DC, pp. 142-143.

Ahout, W. 2009. Personal communication from Willy Ahout, MTT bv, De Pinckart 54, 5674 CC Nuenen, The Netherlands, March 3, 2009.

Alanne, K. "Cost-Optimized Operation of a Residential SOFC Plant.” First International Conference and Workshop on Micro-Cogeneration and Applications. Ottawa, Canada, April 28 - May 2, 2008.

Banwell, P. 2006. "Emerging Technologies: Residential Cogeneration." PowerPoint presentation at the ACEEE MT Symposium, March 21, 2006. Contact information as provided in the presentation: email: banwell.peter@epa.gov , phone: 202-343-9408.

Beyer, D. and N. Kelly 2008. "Modelling the Behavior of Domestic Micro-Cogeneration Under Different Operating Regimes and with Variable Thermal Buffering." First International Conference and Workshop on Micro-Cogeneration and Applications. Ottawa, Canada, April 28 - May 2, 2008.

Davis, M.W. 2008. "Measured Performance of Three Residential Fuel Cell Systems." First International Conference and Workshop on Micro-Cogeneration and Applications. Ottawa, Canada, April 28 - May 2, 2008.

Dorer, V. and A. Weber 2008a. "Performance Assessment of Micro-Cogeneration Systems in Residential Buildings with Different Energy Demand Levels." First International Conference and Workshop on Micro-Cogeneration and Applications. Ottawa, Canada, April 28 - May 2, 2008.

Dorer, V. and A. Weber. 2008b. "Energy and CO2 Emissions Performance Assessment of Residential Micro-Cogeneration Systems with Dynamic Whole-Building Simulation Programs." Energy Conversion and Management 2008, in press (doi:10.1016/j.enconman.2008.10.012).

Hawkes, A.D.; M.A. Leach; and N.P. Brandon 2008. "Economic and Environmental Impacts of Micro-CHP Start-up Performance and Turndown Ratio." First International Conference and Workshop on Micro-Cogeneration and Applications. Ottawa, Canada, April 28 - May 2, 2008.

IEA 2005. "Residential Cogeneration Systems: A Review of Current Technologies," I. Knight and I. Ugursal editors. International Energy Agency Annex 42. Operating agent, Dr. Ian Beausoleil-Morrison, CANMET Energy Technology Centre, 580 Booth Street, $13^{\text {th }}$ Floor, Ottawa, Ontario, Canada, K1A 0E4. June 2005. The report is currently available on the Internet at http://www.ecbcs.org/docs/Annex_42_Review_Residential_Cogen_Technologies.pdf . (Note that if you type this in by hand, the spaces between words are underscored.) 
Kobayashi, K. 2008. "Performance of Residential PEMFC Cogeneration System in Annual Actual Use." First International Conference and Workshop on Micro-Cogeneration and Applications. Ottawa, Canada, April 28 - May 2, 2008.

Lombardi, K.; V.I. Ugursal: and I. Beausoleil-Morrison 2008. "Performance and Emissions Testing of a $1 \mathrm{kWe}$ Stirling Engine." First International Conference and Workshop on MicroCogeneration and Applications. Ottawa, Canada, April 28 - May 2, 2008.

Manning, M.; F. Szadkowski; J. Gusdorf; E. Entchev; M. Swinton; and M. Douglas 2008. "Integration and Monitoring of MicroCHP Systems in a Residential Application at the Canadian Centre for Housing Technology." First International Conference and Workshop on MicroCogeneration and Applications. Ottawa, Canada, April 28 - May 2, 2008.

NREL 2009. PV Watts Web site, source of hourly photovoltaic output at various sites across the United States. The Web address is http://www.nrel.gov/rredc/pvwatts . Data for Bridgeport, Connecticut were used as a proxy for Long Island in the example used in this report.

Slowe, J. 2008. "International Micro-CHP Review and Outlook." First International Conference and Workshop on Micro-Cogeneration and Applications. Ottawa, Canada, April 28 - May 2, 2008 . 


\section{PRIMARY ENERGY SAVINGS BASELINE ANALYSIS}

\section{Analysis Description}

A small-scale combined heat and power (micro-CHP) system sized for residential applications was simulated using hourly loads on an Excel spreadsheet for baseline houses in Albany and Long Island, New York. Two types of system were studied, a "mini" system sized to meet domestic hot water needs only, and a somewhat larger system designed to provide both space heating and domestic hot water.

Loads were supplied by the energy analysis program Energy-10. (For information on this program see the Web site http://www/nrel.gov/buildings/energy10.html .) Thermal storage was by way of the domestic hot water tank. There was no electrical storage and no sellback of cogenerated electric power to the grid. The micro-CHP system was defined by three parameters: electric power output in $\mathrm{kW}$, electrical efficiency, and thermal efficiency. The micro-CHP system was controlled to produce the maximum amount of electrical and thermal energy that the house could accept, consistent with not wasting any of either and also consistent with the limitation of $100 \%$ ontime. Any shortfall in electric power production by the micro-CHP unit was assumed to be taken from the grid. Any shortfall in thermal energy was assumed to be produced by an auxiliary fuel-fired heating system whose efficiency equaled the sum of the electrical and thermal efficiencies of the micro-CHP system.

This system was compared with a conventional system that used an on-site fuel-fired space heating system whose efficiency equaled the sum of the electric and thermal efficiencies of the micro-CHP system. In the conventional system, all the electric power requirements of the house are assumed to be taken from the grid.

The two systems were compared using primary energy savings as the figure of merit. For this comparison, the electric energy taken from the grid was assumed to be produced at $33 \%$ efficiency.

\section{$\underline{\text { Units }}$}

In this analysis, thermal and electrical quantities are expressed in the common engineering units most generally used in the United States. That is, thermal energy is expressed in MBtu ( $\left.10^{6} \mathrm{Btu}\right)$ and thermal power is expressed in MBtuh $\left(10^{6}\right.$ Btu per hour). Electrical energy is expressed in $\mathrm{kWh}$ while power is given in $\mathrm{kW}$. The conversion is the mechanical equivalent of heat, $0.003415 \mathrm{MBtu}$ per kWh.

\section{House Characteristics and Loads}

The hour-by-hour loads used in these simulations were obtained using the default house in the energy analysis program Energy-10. The baseline house was chosen to be a single-story ranchtype house with a conditioned floor area of $2,000 \mathrm{ft}^{2}$. The total surface area (ceiling, floor, and walls) was $5,643 \mathrm{ft}^{2}$. The conditioned volume was $18,000 \mathrm{ft}^{3}$. The average R-values of the ceiling, floor, and walls were $29.4,12.2$, and $12.6 \mathrm{~F}-\mathrm{h}-\mathrm{ft}^{2} / \mathrm{Btu}$, respectively. The total conduction UA was $529.9 \mathrm{Btu} / \mathrm{h}-\mathrm{F}$. 
Heating, cooling, domestic hot water, and electrical loads were treated as follows. The hourly heating loads reported by Energy-10 were used directly, that is, they were balanced against the providers of heat in the simulation, namely the micro-CHP system as the preferred provider plus a hypothetical backup heating system whose efficiency could be specified. The hourly cooling loads reported by Energy-10 were converted to electrical loads assuming a constant energyefficiency ratio (EER) of $12 \mathrm{Btuh} / \mathrm{W}$. Hot water loads were obtained by converting the hourly electicity use for water heating as reported by Energy-10 to a thermal load using the mechanical equivalent of heat, $3415 \mathrm{Btu} / \mathrm{kWh}$. The total electrical load, which was met preferentially by the micro-CHP system backed up by utility power, was obtained by adding the hourly cooling electrical load to the hourly lighting and plug loads reported by Energy-10.

Two locations in New York State were specified in the Statement of Work, one to be on Long Island and the other to be on the Albany-Buffalo axis. Albany was selected as the upstate location. Energy-10 does not provide any weather data on Long Island, so instead Bridgeport, Connecticut was used as a proxy. We could have used New York City, but the heating requirements in the city are significantly less than most Long Island locations, and it was felt that Bridgeport, just across Long Island Sound, would be more representative of the island.

The total annual loads in each location were as follows:

\begin{tabular}{|l|l|l|l|l|}
\hline & $\begin{array}{l}\text { Heating Load } \\
(\mathrm{MBtu})\end{array}$ & $\begin{array}{l}\text { Cooling Load } \\
(\mathrm{MBtu})\end{array}$ & $\begin{array}{l}\text { Hot Water Load } \\
(\mathrm{MBtu})\end{array}$ & $\begin{array}{l}\text { Electrical Load** } \\
(\mathrm{kWh})\end{array}$ \\
\hline Albany & 91.8 & 21.4 & 19.6 & 8290 \\
\hline Long Island* & 70.3 & 22.1 & 19.6 & 8345 \\
\hline
\end{tabular}

\section{Prime Mover Characteristics}

At this point, the simulation of the "prime mover," that is, the device that uses fuel as an input and delivers electricity and heat as outputs, is very general, and may apply equally to an internal combustion engine, a fuel cell, or a free-piston Stirling engine. It is assumed for this baseline analysis that the inputs and outputs are constant as long as the device is operating, and that the device can be turned on or off at will without degrading performance. Clearly, these assumptions will need to be revisited as the analysis becomes more detailed; however, it was seen as desirable to get an overview or "big picture" before examining the details of part-load operation.

Under these simplifying assumptions, three parameters will suffice to describe the prime mover. These could be the electrical efficiency, the thermal efficiency, and the thermal input rate. Alternatively, one might specify the electrical output in $\mathrm{kW}$ as well as the electrical and thermal efficiencies. We have chosen the latter option, mainly because the electrical output in $\mathrm{kW}$ is usually the first specification given for any of these prime movers.

The thermal output in MBtuh is calculated as 0.003415 times the electrical output (in $\mathrm{kW}$ ) multiplied by the thermal efficiency and divided by the electrical efficiency. The thermal input 
is the thermal output divided by the thermal efficiency. These quantities are, of course, constants that only need to be calculated once for each simulation.

\section{Control Strategy}

The control strategy is defined as follows. For each hour of operation, the electrical and thermal loads are given. The electrical load is the sum of the calculated electrical load for air conditioning and the lighting and plug loads provided by Energy-10.

Two fractional ontimes are then calculated. One is based on available "thermal sink" represented by the sum of the thermal load for the hour under consideration and the available thermal storage capacity, i.e., the difference between the total storage capacity and the amount of heat already in storage. A provisional thermal fractional ontime is the ratio of this "thermal sink" in MBtu and the thermal capacity in MBtuh.

In similar fashion, an "electrical sink" is defined as the sum of the hourly electrical load and the available storage capacity, i.e., the difference between the total electrical storage capacity and the amount of electrical energy already in storage. A provisional electrical fractional ontime is the ratio of the "electrical sink" in $\mathrm{kWh}$ and the electrical capacity in $\mathrm{kW}$.

In general, it is assumed that the thermal storage is all on-site. That is, there is no district heating or other thermal transport from the individual building site. On the electrical side, the algorithm is set up to permit either on-site electrical storage or (by setting the available storage to a very large value) sending power back into the grid. For these baseline simulations, it was assumed that there is no on-site electrical storage and no sellback of power to the utility grid. The impact of relaxing these restrictions is to be investigated later.

Also, at this point, losses in storage are ignored. For now, that simply means that thermal storage losses are considered part of the domestic hot water load. This is implicit in the data provided by Energy-10, which reports the electrical energy needed to provide domestic hot water to the house, including storage losses.

The "no-waste" control strategy is executed by selecting the smaller of the two provisional fractional ontimes as the one that controls, unless both of them are greater than unity, in which case the fractional ontime is set equal to 1.0 .

This control strategy may result in a deficiency of either electrical or thermal energy, or both. Additional electrical energy required to meet the load is assumed to be taken from the utility grid. Additional thermal energy required to meet the load is assumed to be taken from a supplementary source of heat, at an efficiency that can be specified independently of the microCHP system.

An example might help to clarify this. Suppose a prime mover has an electrical output of $1 \mathrm{~kW}$ at $20 \%$ efficiency, and the thermal efficiency is $60 \%$. This would mean that the thermal output is $3 \mathrm{~kW}$ (thermal) or $0.010 \mathrm{MBtuh}$. Now suppose for some particular hour the electrical load averages $700 \mathrm{~W}$, or $0.7 \mathrm{kWh}$ for the one-hour period, and the thermal load is 5,000 Btu or 0.005 MBtu. The provisional electrical fractional ontime would then be $0.7 / 1.0$ or 0.7 . If the thermal storage were fully charged, the provisional thermal fractional ontime would be $0.005 / 0.010$ or 
0.5. The lesser of the two provisional ontimes would control, and the micro-CHP would run at $50 \%$ fractional ontime.

However, suppose the thermal storage could take an additional 20,000 Btu (0.020 MBtu). In this case the provisional thermal fractional ontime would be $(0.005+0.020) / 0.010$ or 2.5 . Now the electrical fractional ontime of 0.7 would control, and the micro-CHP would run at $70 \%$ fractional ontime.

Finally in the example, let the latter situation be modified so that the electrical load is $1.3 \mathrm{kWh}$, making the provisional electrical fractional ontime equal to $1.3 / 1.0$ or 1.3 . Here, both provisional ontimes are greater than unity, and the default value of 1.0 is selected, since the system can't run more than $100 \%$ of the time.

To sum up, the micro-CHP system is operated for as large a fractional ontime as possible consistent with avoiding waste of either electrical or thermal energy.

\section{Results - Domestic Hot Water (DHW) System in Albany}

A micro-CHP system sized to meet domestic hot water loads only (not addressing space heating) was modeled. The total efficiency (electrical plus thermal) was set at $75 \%$, as was the efficiency of the hypothetical backup heating system. The system was compared with a conventional water heating system that also operates at 75\% efficiency coupled with grid-supplied electric power. In comparing primary energy used by each system, the overall efficiency of the utility power (including both generation and transmission losses) was set at 33\%. The intent here was to get an overview of the impact of going to the micro-CHP concept, without fogging the issue with possible differences between the overall efficiency of the micro-CHP and the conventional system.

The DHW storage capacity was set at 75,000 Btu (0.075 MBtu), which is equivalent to 100 gallons of water and a temperature difference of $90^{\circ} \mathrm{F}$ between the water supply main and the heated water.

With the DHW storage capacity and the overall efficiency of the micro-CHP system held constant, two other quantities were varied as parameters: the electrical efficiency and the electrical output in $\mathrm{kW}$ of the micro-CHP unit.

Electrical efficiencies ranging from $10 \%$ to $25 \%$ were modeled in $5 \%$ increments. The thermal efficiency was varied in the reverse direction, i.e., from $65 \%$ to $50 \%$, in order to keep the overall efficiency at the benchmark value of $75 \%$. Electrical output rates were varied from 100 to 500 $\mathrm{W}(0.1$ to $0.5 \mathrm{~kW})$, with five intermediate values. This provided a matrix of 28 baseline simulations. Operating characteristics and annual energy flows for these systems are given in Appendix 2-1.

The technical merit of the system was summarized by calculating the primary energy used by the micro-CHP system - supplemented where necessary by auxiliary heat and grid-supplied power and comparing that with the primary energy used to meet the same loads using only grid electricity and the auxiliary heating unit, with no micro-CHP. The results for the house in Albany are shown in Figure 2-1. In this figure the horizontal axis is the electrical output of the 
micro-CHP unit in $\mathrm{kW}$, while a separate line is shown for each of the parameterized values of electrical efficiency. The curves are similar in two ways: each rises along a straight line from the origin and then flattens out to a horizontal line at higher electrical output rates. The horizontal portions of each line represent a situation in which the unit's operation is limited by the thermal load of the house (including the ability of storage to take heat). Once this plateau is reached, increasing the capacity of the micro-CHP unit does no good. In this simulation, where performance degradation under part-load operation is not considered, it does no harm, either, but it would be well at this point, even in advance of more detailed simulations, to point out the expectation that when part-load characteristics are included, the primary energy savings are expected to peak and then tail off as the system is increased in size.

The slanted portion of each line that rises from the origin to link up with the horizontal section to the right represents the situation in which the unit is small enough that it can run all the time without exceeding the ability of the thermal and electrical demands of the house (including the thermal storage) to accept the output. A look Column 5 of Appendix 2-1 shows this. The fractional ontime of the micro-CHP unit is less than one at the higher electrical output rates, but rises to this maximum possible value as the size of the unit decreases.

Two salient observations emerge from this graph. First, if it is desired to maximize primary energy savings, then the unit should be sized to place its operating point near the left end of the horizontal portion of the curve that reflects its electrical efficiency. Second, the electrical efficiency of the unit matters greatly. The primary energy savings for a unit with $25 \%$ electrical efficiency is more than double that produced by a unit whose electrical efficiency is $15 \%$ and more than three times the savings for the $10 \%$-efficient unit. This comes about because the system's operating time is limited by the thermal load. Increasing the electrical efficiency decreases the thermal efficiency. Thus, the unit that is $25 \%$ efficient in terms of electrical output produces heat at twice the rate it produces electricity, whereas the unit that is $10 \%$ efficient electrically produces heat at 6.5 times the rate at which it produces electricity. The ratio of 6.5 to $2(3.25)$ is approximately equal to the ratio of energy savings produced by the $25 \%$ and $10 \%$ electric-efficiency units. For this reason the primary energy savings are more than proportional to the electrical efficiency. This will contrast sharply with the situation for a system designed to meet both space-heating and DHW loads, to which we now turn.

\section{Results - Space Heating and DHW System in Albany}

A micro-CHP system sized to meet both space-heating and domestic hot water loads was also modeled. The total efficiency (electrical plus thermal) was set at $85 \%$, as was the efficiency of the hypothetical backup heating system. (The baseline efficiency was set higher than in the DHW-only case in recognition that fuel-fired space-heating systems are on average more efficient than DHW systems. No implication that the average efficiencies of these systems in New York State or the U.S. as a whole should be inferred.) The system was compared with a conventional heating system that also operates at $85 \%$ efficiency coupled with grid-supplied electric power. In comparing primary energy used by each system, the overall efficiency of the utility power (including both generation and transmission losses) was set at $33 \%$. As in the DHW-only case, the intent was to get an overview of the impact of going to the micro-CHP concept, without fogging the issue with possible differences between the overall efficiency of the micro-CHP and the conventional system. 
The DHW storage capacity was set at the same value (0.075 MBtu) as in the DHW-only case. The DHW tank is the only thermal storage assumed in this set of simulations.

As in the previous case, the electrical efficiency and the electrical output in $\mathrm{kW}$ of the micro$\mathrm{CHP}$ unit were varied as parameters. Electrical efficiencies ranging from $10 \%$ to $25 \%$ were modeled in 5\% increments, and the thermal efficiency was varied in the reverse direction (but now from $75 \%$ to $60 \%$, in order to keep the overall efficiency at the benchmark value of $85 \%$ ). However, the range of electrical output rates was changed, with the lower limit now being 0.3 $\mathrm{kW}$ and the upper limit set at $3 \mathrm{~kW}$. Six intermediate values were also simulated. This provided a matrix of 32 baseline simulations. Operating characteristics and annual energy flows for these systems are given in Appendix 2-2.

The technical merit of the system was summarized as before, by calculating the primary energy used by the micro-CHP system along with any necessary auxiliary heat and grid-supplied power, and comparing that with the primary energy used to meet the same loads using only grid electricity and the auxiliary heating unit, with no micro-CHP. The results for the house in Albany are shown in Figure 2-2. As in the DHW-only case, the horizontal axis is the electrical output of the micro-CHP unit in $\mathrm{kW}$, while a separate line is shown for each of the parameterized values of electrical efficiency. As in the DHW-only case, each curve rises along a straight line from the origin and then flattens out to a horizontal line at higher electrical output rates. The horizontal portions of each line represent a situation in which the unit is able to meet all the electrical loads of the house. Once this plateau is reached, increasing the capacity of the microCHP unit does no good. Also as in the DHW-only case, it is well to remind the reader that performance degradation under part-load operation is not considered. If it were, the rightmost ends of these curves would probably slope downward somewhat rather than remaining horizontal.

The primary observation from Figure 2-2 is that although these curves have the same general shape as their counterparts in Figure 2-1, there is a very important difference. In contrast to the DHW-only case, where the energy savings was more than proportional to the electrical efficiency, here the reverse is the case. The maximum energy savings for the micro-CHP system with $25 \%$ electrical energy is only $50 \%$ greater than that for the one with $10 \%$ electrical efficiency, despite the fact that its electrical efficiency is $150 \%$ greater.

Is that reasonable? There is reason to believe that it is, in the following respect. During much of the heating season, the fractional ontime of the unit is limited by the electrical load, not the thermal load as in the DHW-only case. This is true even for the unit whose electrical efficiency is only $10 \%$, although the limitation by electrical load does extend to a greater portion of the year for the unit with $25 \%$ electrical efficiency. For those cases where the fractional ontime is limited by the electrical load, the energy savings for the $10 \%$ and $25 \%$ units will be the same. They both produce the same amount of electricity, while the combination of the micro-CHP unit and the auxiliary heater produces the same amount of heat. Moreover, the heat and the electric energy together are produced at the same efficiency, namely $85 \%$.

It is only when the $25 \%$ unit is limited by the electric load while the $10 \%$ unit is limited by the thermal load (or runs flat out) that the more electrically efficient unit saves more energy. This happens often enough, especially in the warm months, but because much of the time it doesn't 
happen the improvement in annual energy savings is less than proportional to the electrical efficiency.

Another observation that can be made is that, in view of the fact that the primary energy savings tops out at a particular value of the electrical output in $\mathrm{kW}$, there appears to be no benefit from going to a larger system. Two important caveats are required here, however. First, the impact on efficiency of part-load operation have not yet been considered. Many systems perform less well under part-load conditions than under full-load operation. Other systems, in particular internal combustion engines, achieve their maximum efficiency at much less than maximum speed. Second, the analysis so far has not considered the effect of reverse metering. If that is permitted, it is likely that the system designed for both space heating and DHW may save more primary energy if sized larger than the $1.5 \mathrm{~kW}$ output that appears to be optimal here.

\section{Results on Long Island}

The same simulations were run for Long Island (using Bridgeport, Connecticut loads as a proxy) as for Albany. Although the annual space heating load was 23\% less than in Albany, the results are essentially the same. The summary charts for Long Island (DHW-only and space heat plus DHW) are given in Appendices 2-3 and 2-4. The energy savings results are shown in Figures 23 and 2-4. The DHW results are identical in both locations, while the energy savings on Long Island are slightly lower. The differences, however, are too slight to be of note.

\section{Summary and Conclusions}

A micro-CHP system was simulated using hourly loads on an Excel spreadsheet for baseline houses in Albany and Long Island, New York. Thermal storage was by way of the domestic hot water tank. There was no electrical storage and no sellback of cogenerated electric power to the grid. The micro-CHP system was defined by three parameters: electric power output in $\mathrm{kW}$, electrical efficiency, and thermal efficiency. The micro-CHP system was controlled to produce the maximum amount of electrical and thermal energy that the house could accept, consistent with not wasting any of either and also consistent with the limitation of $100 \%$ ontime. Any shortfall in electric power production by the micro-CHP unit was assumed to be taken from the grid. Any shortfall in thermal energy was assumed to be produced by an auxiliary fuel-fired heating system whose efficiency equaled the sum of the electrical and thermal efficiencies of the micro-CHP system.

This system was compared with a conventional system that used an on-site fuel-fired space heating system whose efficiency equaled the sum of the electric and thermal efficiencies of the micro-CHP system. In this system, all the electric power requirements of the house were assumed to be taken from the grid.

The two systems were compared using primary energy savings as the figure of merit. For this comparison, the electric energy taken from the grid was assumed to be produced at $33 \%$ efficiency.

The salient conclusion was that for systems sized sufficiently large to maximize the primary energy savings, these savings were more than proportional to the electric efficiency of the microCHP unit for the DHW system. However, for the combined space heating and DHW system, the 
primary energy savings were less than proportional to the electric efficiency of the micro-CHP unit. Thus, a micro-CHP unit of relatively low electric efficiency might be useful in the combined system, but is less likely to be an attractive option for the DHW-only system. 


\section{DHW SYSTEM IN ALBANY}

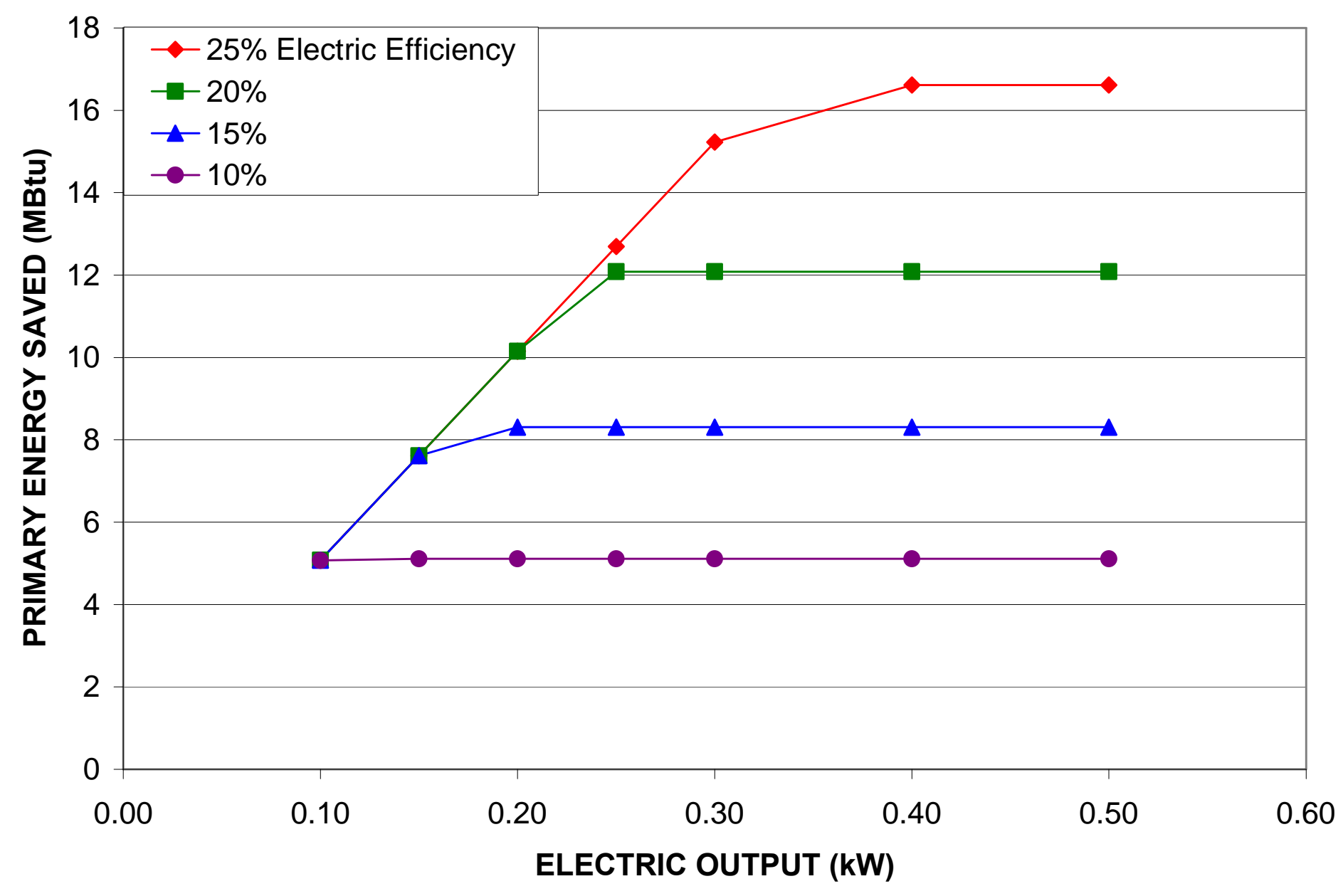

Figure 2-1. Primary energy savings for DHW-only systems in Albany 


\section{HEATING AND DHW IN ALBANY}

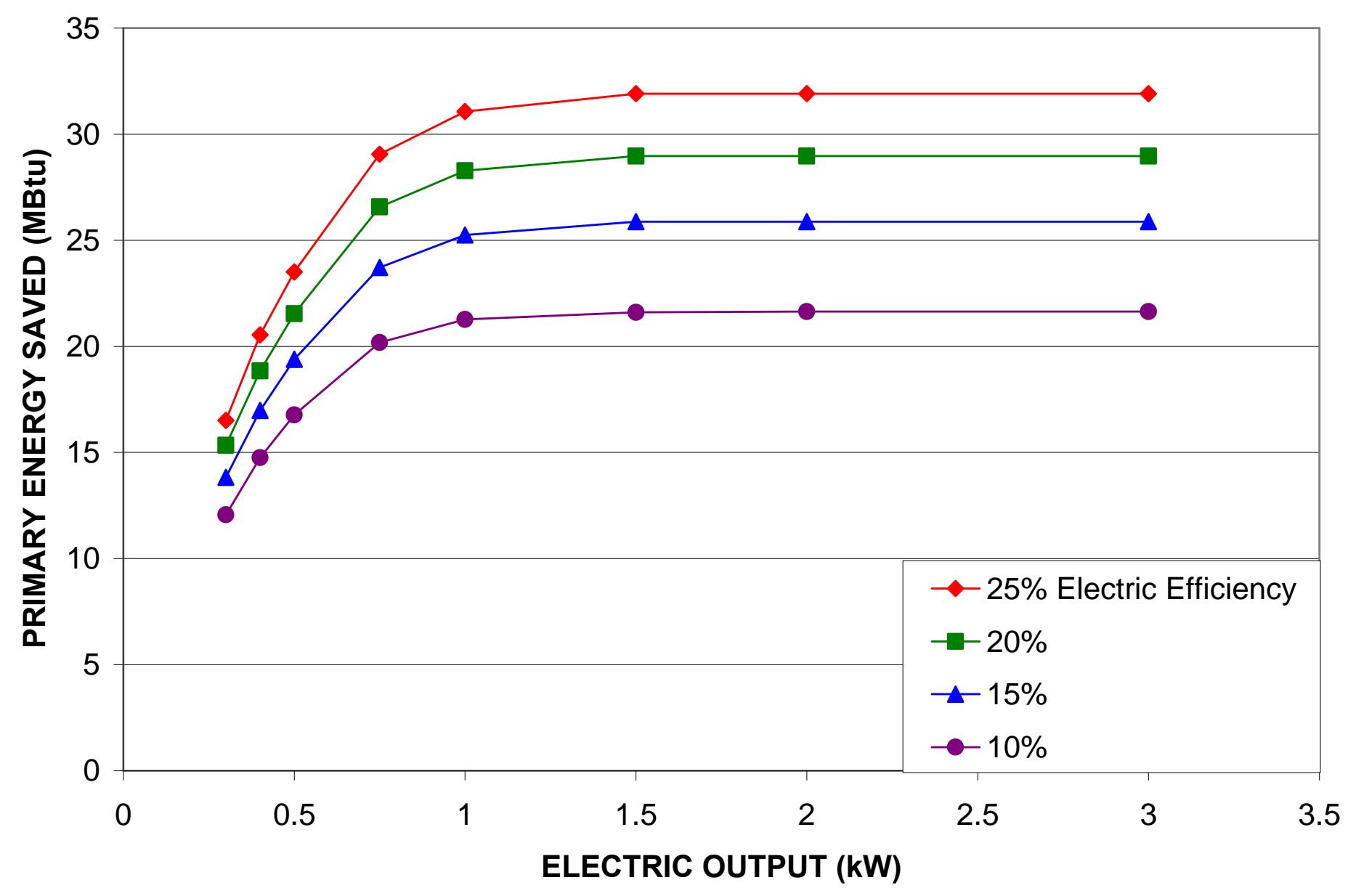

Figure 2-2. Primary energy savings for combined space heat and DHW systems in Albany 


\section{DHW SYSTEM ON LONG ISLAND}

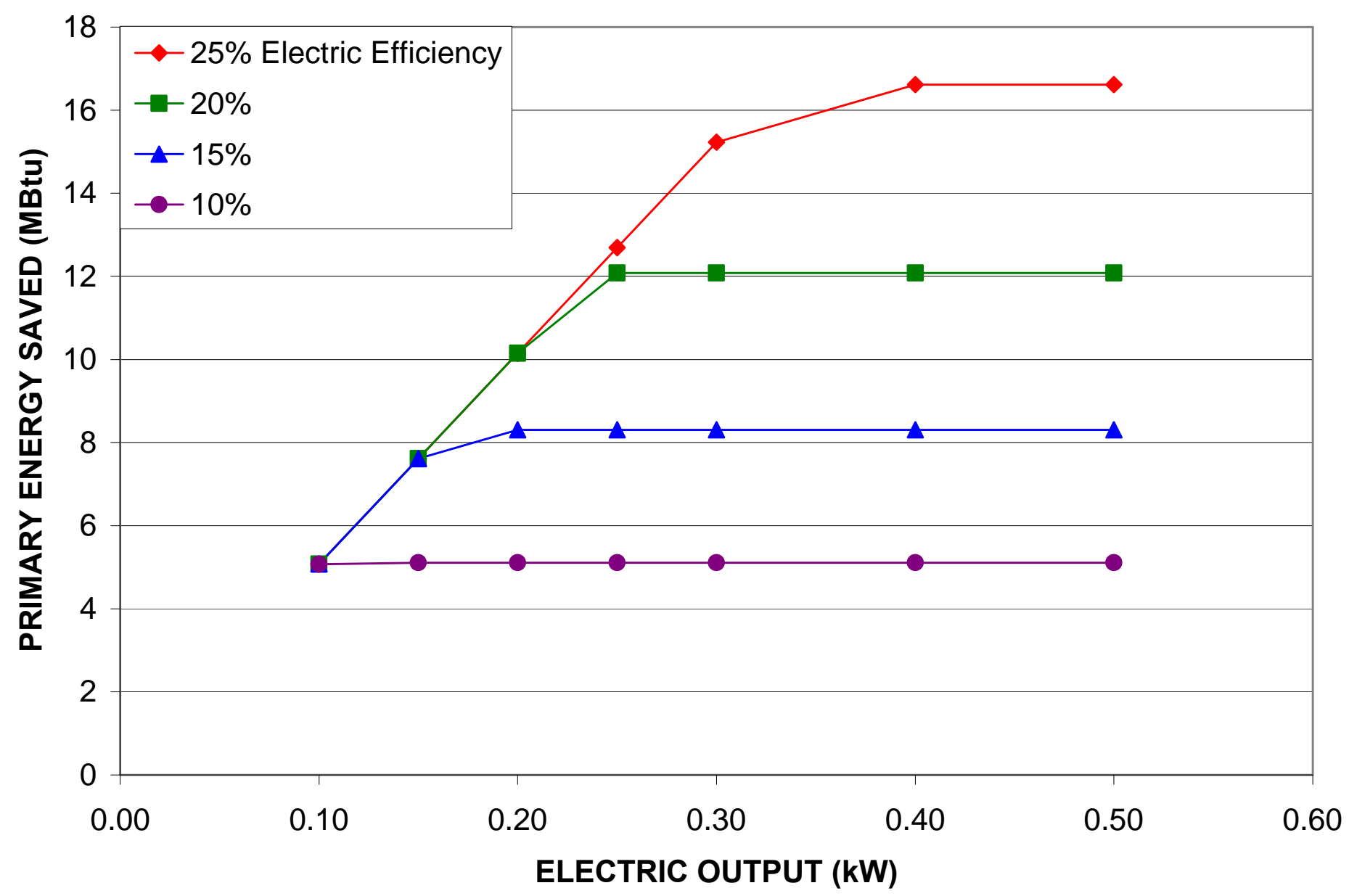

Figure 2-3. Primary energy savings for DHW-only systems on Long Island 


\section{HEATING AND DHW ON LONG ISLAND}

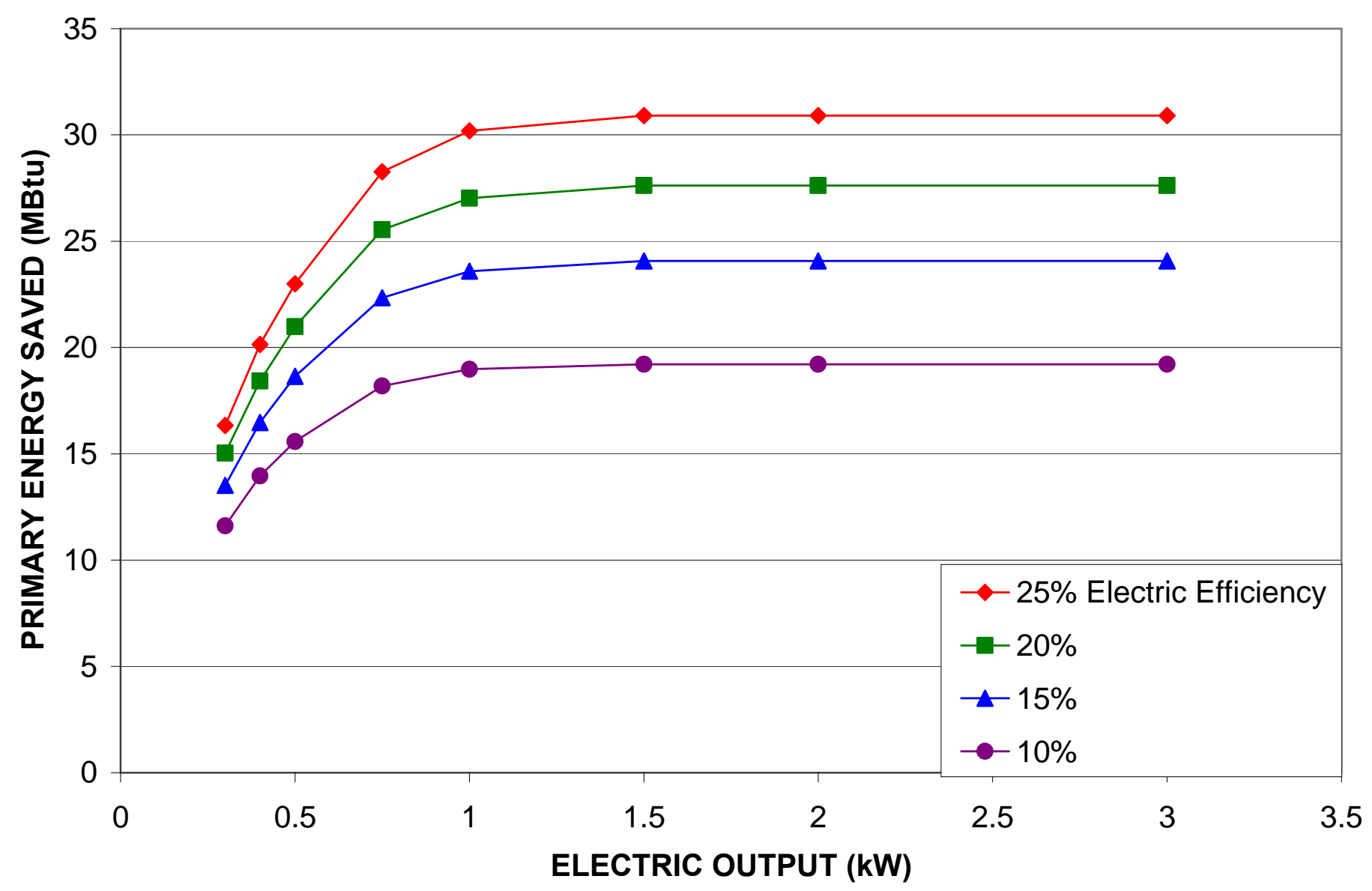

Figure 2-4. Primary energy savings for combined space heat and DHW systems on Long Island 


\section{SECTION 2 APPENDICES}

Appendix 2-1. Summary Data for DHW System in Albany DHW SYSTEM IN ALBANY

micro-CHP operating parameters =

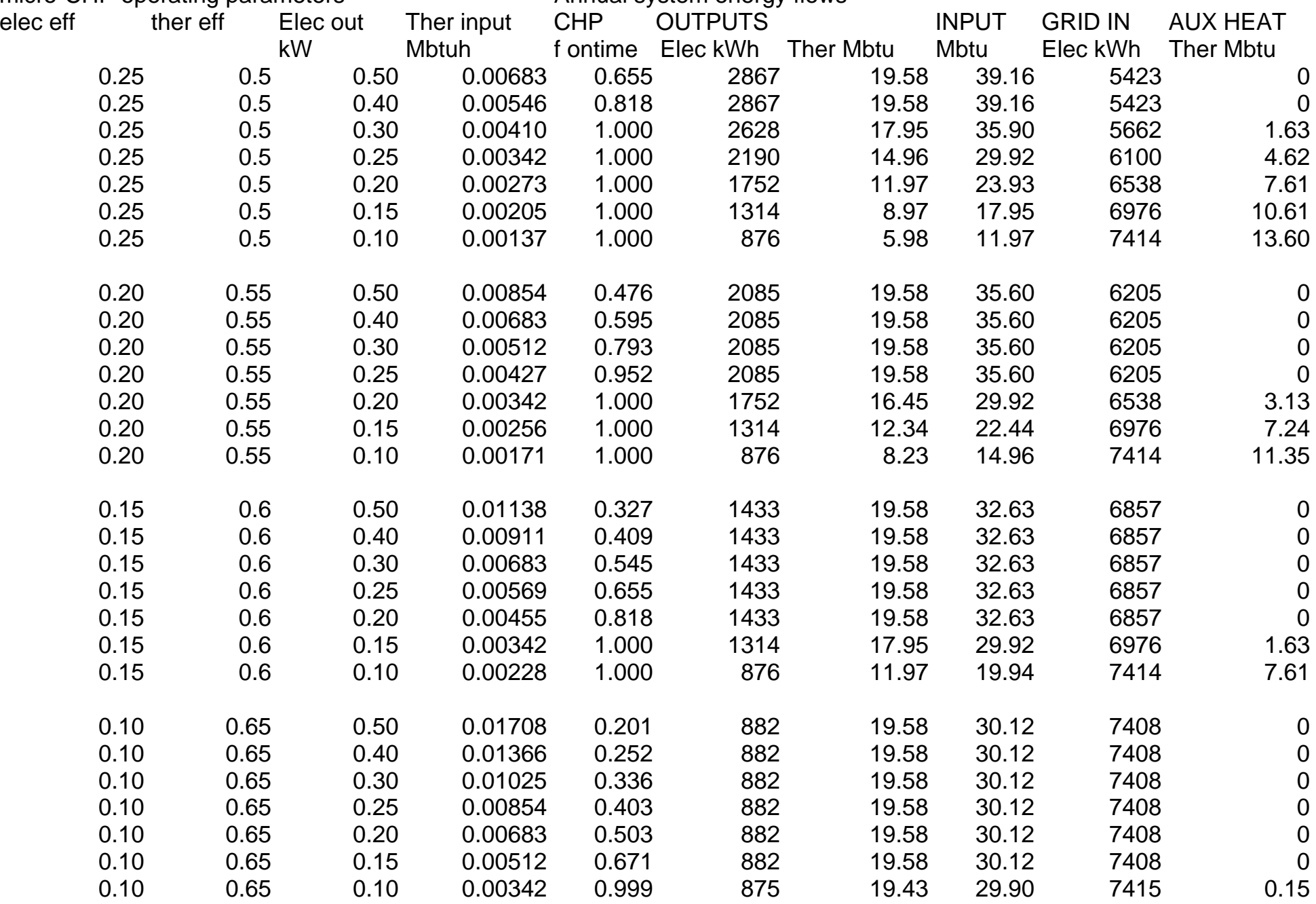

Annual system energy flows 
Appendix 2-2. Summary Data for Space Heating and DHW System in Albany

micro-CHP operating parameters =======

\begin{tabular}{|c|c|c|c|c|c|c|c|c|c|}
\hline & & & & & & & & & \\
\hline & & Elec out & Ther input & CHP & UTPUTS & & INPUT & GRID IN & AUX HEAT \\
\hline elec eff & & & & & Elec kWh & Ther Mbtu & Mbtu & Elec kWh & Ther Mbtu \\
\hline 0.25 & 0.6 & 3 & 0.04098 & 0.192 & 5040 & 41.31 & 68.84 & 3250 & 70.12 \\
\hline 0.25 & 0.6 & 2 & 0.02732 & 0.288 & 5040 & 41.31 & 68.84 & 3250 & 70.12 \\
\hline 0.25 & 0.6 & 1.5 & 0.02049 & 0.384 & 5040 & 41.31 & 68.84 & 3250 & 70.12 \\
\hline 0.25 & 0.6 & 1 & 0.01366 & 0.56 & 4907 & 40.22 & 67.03 & 3383 & 71.20 \\
\hline 0.25 & 0.6 & 0.75 & 0.01025 & 0.698 & 4589 & 37.61 & 62.68 & 3701 & 73.82 \\
\hline 0.25 & 0.6 & 0.5 & 0.00683 & 0.848 & 3714 & 30.44 & 50.73 & 4577 & 80.99 \\
\hline 0.25 & 0.6 & 0.4 & 0.00546 & 0.926 & 3245 & 26.6 & 44.33 & 5045 & 84.83 \\
\hline 0.25 & 0.6 & 0.3 & 0.00410 & 0.993 & 2608 & 21.38 & 35.63 & 5682 & 90.05 \\
\hline 0.2 & 0.65 & 3 & 0.05123 & 0.174 & 4576 & 50.79 & 78.14 & 3714 & 60.63 \\
\hline 0.2 & 0.65 & 2 & 0.03415 & 0.261 & 4576 & 50.79 & 78.14 & 3714 & 60.63 \\
\hline 0.2 & 0.65 & 1.5 & 0.02561 & 0.348 & 4576 & 50.79 & 78.14 & 3714 & 60.63 \\
\hline 0.2 & 0.65 & 1 & 0.01708 & 0.51 & 4466 & 49.57 & 76.26 & 3824 & 61.86 \\
\hline 0.2 & 0.65 & 0.75 & 0.01281 & 0.639 & 4197 & 46.58 & 71.66 & 4094 & 64.85 \\
\hline 0.2 & 0.65 & 0.5 & 0.00854 & 0.777 & 3402 & 37.76 & 58.09 & 4888 & 73.67 \\
\hline 0.2 & 0.65 & 0.4 & 0.00683 & 0.85 & 2977 & 33.04 & 50.84 & 5313 & 78.38 \\
\hline 0.2 & 0.65 & 0.3 & 0.00512 & 0.922 & 2423 & 26.89 & 41.37 & 5867 & 84.53 \\
\hline 0.15 & 0.7 & 3 & 0.06830 & 0.156 & 4087 & 65.13 & 93.05 & 4203 & 46.29 \\
\hline 0.15 & 0.7 & 2 & 0.04553 & 0.233 & 4087 & 65.13 & 93.05 & 4203 & 46.29 \\
\hline 0.15 & 0.7 & 1.5 & 0.03415 & 0.311 & 4087 & 65.13 & 93.05 & 4203 & 46.29 \\
\hline 0.15 & 0.7 & 1 & 0.02277 & 0.455 & 3989 & 63.57 & 90.81 & 4301 & 47.86 \\
\hline 0.15 & 0.7 & 0.75 & 0.01708 & 0.57 & 3747 & 59.72 & 85.31 & 4543 & 51.71 \\
\hline 0.15 & 0.7 & 0.5 & 0.01138 & 0.699 & 3063 & 48.81 & 69.73 & 5227 & 62.62 \\
\hline 0.15 & 0.7 & 0.4 & 0.00911 & 0.766 & 2682 & 42.75 & 61.07 & 5608 & 68.68 \\
\hline 0.15 & 0.7 & 0.3 & 0.00683 & 0.832 & 2185 & 34.83 & 49.75 & 6105 & 76.60 \\
\hline 0.1 & 0.75 & 3 & 0.10245 & 0.130 & 3419 & 87.56 & 116.74 & 4872 & 23.87 \\
\hline 0.1 & 0.75 & 2 & 0.06830 & 0.195 & 3419 & 87.56 & 116.74 & 4872 & 23.87 \\
\hline 0.1 & 0.75 & 1.5 & 0.05123 & 0.260 & 3419 & 87.56 & 116.74 & 4872 & 23.90 \\
\hline 0.1 & 0.75 & 1 & 0.03415 & 0.383 & 3359 & 86.03 & 114.71 & 4931 & 25.39 \\
\hline 0.1 & 0.75 & 0.75 & 0.02561 & 0.485 & 3188 & 81.65 & 108.87 & 5102 & 29.77 \\
\hline 0.1 & 0.75 & 0.5 & 0.01708 & 0.605 & 2649 & 67.85 & 90.47 & 5641 & 43.57 \\
\hline 0.1 & 0.75 & 0.4 & 0.01366 & 0.665 & 2331 & 59.69 & 79.59 & 5959 & 51.73 \\
\hline 0.1 & 0.75 & 0.3 & 0.01025 & 0.725 & 1905 & 48.8 & 65.06 & 6385 & 62.63 \\
\hline
\end{tabular}


Appendix 2-3. Summary Data for DHW System on Long Island

micro-CHP operating parameters $=====$

elec eff

ther eff Elec out Ther input

Annual system energy flows =

CHP OUTPUTS

Mbtuh

f ontime

Elec kWh

kWh Ther Mbtu

INPUT

GRID IN

AUX HEAT

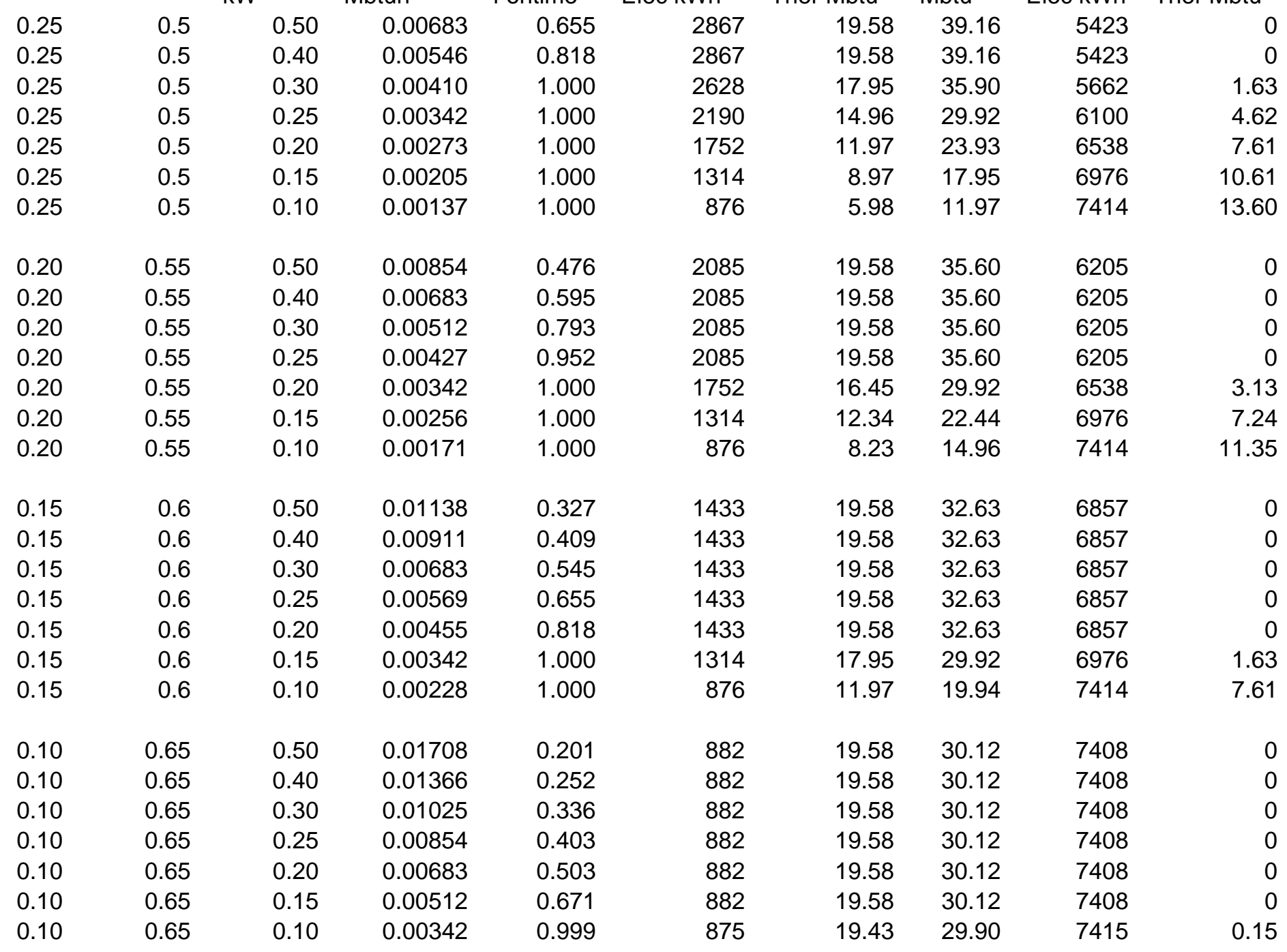


Appendix 2-4. Summary Data for Space Heating and DHW System on Long Island micro-CHP operating parameters $==$ elec eff

operating parameters $==========$
ther eff Elec out Ther input

Annual system energy flows

CHP OUTPUTS

INPUT
INTH

GRID IN

AUX HEAT

f ontime Elec kWh Ther Mbtu Mbtu Elec kWh Ther Mbtu

\begin{tabular}{|c|c|c|c|c|c|c|c|c|c|}
\hline & & & & & & & & & \\
\hline 0.25 & 0.6 & 3 & 0.04098 & 0.186 & 4882 & 40.01 & 66.69 & 3463 & 49.89 \\
\hline 0.25 & 0.6 & 2 & 0.02732 & 0.279 & 4882 & 40.01 & 66.69 & 3463 & 49.89 \\
\hline 0.25 & 0.6 & 1.5 & 0.02049 & 0.372 & 4882 & 40.01 & 66.69 & 3463 & 49.89 \\
\hline 0.25 & 0.6 & 1 & 0.01366 & 0.544 & 4769 & 39.09 & 65.15 & 3576 & 50.81 \\
\hline 0.25 & 0.6 & 0.75 & 0.01025 & 0.679 & 4464 & 36.59 & 60.98 & 3881 & 53.31 \\
\hline 0.25 & 0.6 & 0.5 & 0.00683 & 0.829 & 3633 & 29.77 & 49.62 & 4712 & 60.13 \\
\hline 0.25 & 0.6 & 0.4 & 0.00546 & 0.908 & 3181 & 26.08 & 43.46 & 5164 & 63.83 \\
\hline 0.25 & 0.6 & 0.3 & 0.00410 & 0.982 & 2579 & 21.14 & 35.23 & 5766 & 68.76 \\
\hline 0.2 & 0.65 & 3 & 0.05123 & 0.166 & 4363 & 48.42 & 74.5 & 3982 & 41.48 \\
\hline 0.2 & 0.65 & 2 & 0.03415 & 0.249 & 4363 & 48.42 & 74.5 & 3982 & 41.48 \\
\hline 0.2 & 0.65 & 1.5 & 0.02561 & 0.332 & 4363 & 48.42 & 74.5 & 3982 & 41.48 \\
\hline 0.2 & 0.65 & 1 & 0.01708 & 0.487 & 4270 & 47.39 & 72.91 & 4076 & 42.51 \\
\hline 0.2 & 0.65 & 0.75 & 0.01281 & 0.614 & 4035 & 44.79 & 68.9 & 4310 & 45.11 \\
\hline 0.2 & 0.65 & 0.5 & 0.00854 & 0.757 & 3314 & 36.78 & 56.59 & 5031 & 53.12 \\
\hline 0.2 & 0.65 & 0.4 & 0.00683 & 0.83 & 2910 & 32.29 & 49.68 & 5436 & 57.61 \\
\hline 0.2 & 0.65 & 0.3 & 0.00512 & 0.904 & 2375 & 26.36 & 40.55 & 5970 & 63.54 \\
\hline 0.15 & 0.7 & 3 & 0.06830 & 0.145 & 3803 & 60.61 & 86.58 & 4542 & 29.30 \\
\hline 0.15 & 0.7 & 2 & 0.04553 & 0.217 & 3803 & 60.61 & 86.58 & 4542 & 29.30 \\
\hline 0.15 & 0.7 & 1.5 & 0.03415 & 0.289 & 3803 & 60.61 & 86.58 & 4542 & 29.30 \\
\hline 0.15 & 0.7 & 1 & 0.02277 & 0.425 & 3725 & 59.37 & 84.82 & 4620 & 30.53 \\
\hline 0.15 & 0.7 & 0.75 & 0.01708 & 0.537 & 3529 & 56.24 & 80.35 & 4816 & 33.66 \\
\hline 0.15 & 0.7 & 0.5 & 0.01138 & 0.672 & 2944 & 46.92 & 67.04 & 5401 & 42.98 \\
\hline 0.15 & 0.7 & 0.4 & 0.00911 & 0.743 & 2602 & 41.46 & 59.23 & 5744 & 48.44 \\
\hline 0.15 & 0.7 & 0.3 & 0.00683 & 0.812 & 2134 & 34.01 & 48.58 & 6212 & 55.90 \\
\hline 0.1 & 0.75 & 3 & 0.10245 & 0.115 & 3035 & 77.73 & 103.64 & 5311 & 12.17 \\
\hline 0.1 & 0.75 & 2 & 0.06830 & 0.173 & 3035 & 77.73 & 103.64 & 5311 & 12.17 \\
\hline 0.1 & 0.75 & 1.5 & 0.05123 & 0.231 & 3035 & 77.73 & 103.64 & 5311 & 12.17 \\
\hline 0.1 & 0.75 & 1 & 0.03415 & 0.342 & 2997 & 76.76 & 102.34 & 5348 & 13.14 \\
\hline 0.1 & 0.75 & 0.75 & 0.02561 & 0.437 & 2873 & 73.58 & 98.11 & 5472 & 16.32 \\
\hline 0.1 & 0.75 & 0.5 & 0.01708 & 0.562 & 2461 & 63.04 & 84.06 & 5884 & 26.86 \\
\hline 0.1 & 0.75 & 0.4 & 0.01366 & 0.629 & 2205 & 56.48 & 75.31 & 6140 & 33.42 \\
\hline 0.1 & 0.75 & 0.3 & 0.01025 & 0.698 & 1834 & 46.98 & 62.64 & 6511 & 42.92 \\
\hline
\end{tabular}




\section{EFFECT OF THERMAL STORAGE AND REVERSE METERING}

\section{Analysis Description}

This is a continuation of the analysis of the preceding section. The same house and loads are used here as in the last section. This section builds on that analysis by investigating:

- The impact of thermal storage capacity

- The effect of reverse metering on primary energy savings.

- Consumer savings on annual energy costs for benchmark fuel and electricity prices.

As was explained in the previous section, it should be emphasized that certain simplifying assumptions were made. These include:

- Constant electric and thermal efficiencies for all means of production of heat and electricity, regardless of turndown or fractional ontime.

- No electrical storage.

- Thermal storage is limited to domestic hot water (DHW) tank. Storage losses are taken as constant and included in the DHW load.

It should also be noted that, because the analysis is carried out on an hour-by-hour basis, the assumption of a given load for each particular hour entails the assumption of enough storage (both electrical and thermal) to allow the micro-CHP system to serve the actual load profile within that hour regardless of its minute-by-minute profile. This can be an issue with electric loads (with no storage) and DHW loads (in the event of sudden large draws that exceed storage capacity) but probably not with space-heating loads, because of the thermal mass of the house. With these caveats, it bears repeating that the purpose of the analysis was to get an overview or "big picture," not to examine the details of part-load operation.

\section{Thermal Storage Capacity}

In the previous section, two system types were investigated: a DHW-only system and a somewhat larger system capable of providing both DHW and space heat. In each case, the thermal storage was assumed to be a 100 gallon water tank with a $90{ }^{\circ} \mathrm{F}$ temperature rise from the supply mains to the stored hot water. This resulted in a thermal capacity of 75,000 Btu $(0.075 \mathrm{MBtu})$. We now wanted to determine how sensitive the results are to variations in this thermal capacity. The results show very low sensitivity.

The table on the next page shows the primary energy savings for a $0.3 \mathrm{~kW}$ micro-CHP DHWonly system. Electrical efficiencies of $25 \%$ and $20 \%$ are considered. Storage capacities of half the baseline $(37,500 \mathrm{Btu})$, baseline $(75,000 \mathrm{Btu})$ and twice baseline $(150,000 \mathrm{Btu})$ are shown. The same results are also shown in Figure 3-1.

Within the range considered, there is essentially no dependence on thermal storage capacity. Of course, in a real system in which DHW loads might vary considerably from the benchmark values used by Energy-10, storage capacity might matter. Also, as stated earlier, there is an implicit assumption of enough storage to smooth out the loads within a one-hour time scale. 
Primary Energy Saved in DHW-Only Systems as Function of Thermal Storage Capacity

\begin{tabular}{|l|l|l|l|l|}
\hline \multirow{2}{*}{ Location } & $\begin{array}{l}\text { Electric } \\
\text { Efficiency }\end{array}$ & 37,500 & 75,000 & \multicolumn{3}{|c|}{ Thermal Storage Capacity (Btu) } \\
\cline { 3 - 6 } & $25 \%$ & 15.23 & 15.23 & 15.000 \\
\cline { 2 - 5 } Albany & $20 \%$ & 12.08 & 12.08 & 12.08 \\
\hline \multirow{2}{*}{ Long Island } & $25 \%$ & 15.23 & 15.23 & 15.23 \\
\cline { 2 - 5 } & $20 \%$ & 12.08 & 12.08 & 12.08 \\
\hline
\end{tabular}

For the combined space-heating/DHW systems, the situation is a little more interesting. Figure 3-2 shows the primary energy savings for micro-CHP with baseline thermal storage capacity, compared with systems having half and twice the baseline value. In addition, a "no-storage" result is also shown, although this must be taken with the above-stated caveat that some storage is implicitly assumed even when zero is inserted into the model. Figure 3-2 also shows the primary energy savings for a system with neither DHW loads nor thermal storage.

These results can be summarized in the statement that a fourfold variation in thermal storage capacity, from half to twice the baseline value, changes the primary energy savings by just $6 \%$. The impact of the same storage variation on Long Island (Figure 3-3) is slightly larger, 7.5\%.

The main conclusion from these results is that the selection of thermal storage capacity should be based on practical considerations of convenience, installed cost, and energy details (such as variable storage losses) that are not captured in this baseline analysis. That is, there appears to be no overarching "big-picture effect" that we need to be concerned about.

\section{Reverse Metering}

The next objective in this analysis was to investigate the impact of reverse metering on the primary energy savings for the various systems under consideration. Reverse metering was included in the analysis in the following manner. Instead of controlling on the lower of the two fractional ontimes dictated by the available hourly thermal and electrical sinks (heating load plus available thermal storage capacity in the former case, electric load in the latter case), we now control on a heat-following basis, i.e., to deliver as much of the thermal load plus available storage as the unit is capable of. In some cases this will result in the production of more electric energy than the residence requires. The extra electric energy is assumed to be delivered back to the grid. Transmission losses are ignored, so the real-world primary energy savings on the reverse-metered electric energy will be somewhat less than what this analysis indicates.

One of the main drawbacks of micro-CHP systems that are reverse-metered, from the standpoint of the electric utility, is the fact that these systems will produce excess electric power during the winter months, when heat loads are high, but not in the summer. This is the exact opposite to what U.S. utilities, nearly all of which are summer-peaking, would like to see. It contrasts sharply with the situation for photovoltaic (PV) installations, which provide most of their electric output during the air-conditioning season, when utilities are more in need of generating capacity. Although the match of PV output to utility system load is not perfect, it is much better than that for micro-CHP. This at least is the conventional wisdom. It was therefore desired to see whether this analysis would produce results in agreement with this assessment. 
For the small DHW-only systems, the result was that the capability of reverse metering did not affect the results, because the system never used it. In all cases the heat load for DHW was small enough that no excess electric power was produced. The total electric energy that was reverse metered was zero in all cases, and the primary energy savings was unaffected by the availability of reverse metering or the lack thereof.

For the combined space heating/DHW systems, the results were quite different. Here power was sent back into the grid, the amount varying strongly with the electric capacity of the micro-CHP unit. Figure 3-4, which shows the monthly amounts of electric energy reverse-metered for the $25 \%$ electric-efficiency system in Albany, illustrates the general trend.

Systems with electric generation capacities ranging from $1 \mathrm{~kW}$ to $5 \mathrm{~kW}$ were modeled. For the smallest system, relatively little electric energy was sent back to the grid even in winter. As the electric generation capacity of the system increases, more and more electric energy is returned to the grid in the cold months, while very little is sent back from May through September. The $5 \mathrm{~kW}$ system reverse-meters $2100 \mathrm{kWh}$ in January, the peak month. Increasing the capacity beyond $5 \mathrm{~kW}$ makes little difference. A $10 \mathrm{~kW}$ system reverse-meters only $0.4 \%$ more electricity annually than does the $5 \mathrm{~kW}$ system. This is because the $5 \mathrm{~kW}$ system is already large enough to meet nearly all of the thermal loads. Once one makes the system large enough to eliminate the need for auxiliary heat, making it larger does not increase electrical output.

Figures 3-5, 3-6, and 3-7 show analogous results for the systems with electric efficiencies of $20 \%, 15 \%$, and $10 \%$, respectively. The trend is clear: as the electric efficiency of the system decreases, the amount of electric energy that is reverse metered declines. At $10 \%$ electric efficiency, relatively little electric energy is sent back to the grid regardless of the capacity of the micro-CHP unit. Ironically perhaps, if electric utilities are fearful of reverse-metered micro-CHP systems, it appears that the more efficient they are, the bigger their threat to the load curve.

Figures 3-8 through 3-11 show the results for Long Island. These are sufficiently similar to the Albany results that little additional comment is needed, beyond the observation that because of the somewhat lower heating loads, the amount of electricity sent back to the grid is also somewhat lower than in Albany.

We now turn to the impact of reverse metering on primary energy savings. In general, any electric energy that is returned to the grid should result in primary energy savings as long as the overall efficiency (electric plus thermal) of the micro-CHP unit is greater than the electric generation efficiency at the utility power plant (assuming no use of the heat produced there).

Figure 3-12 shows the primary energy savings for systems with micro-CHP units with electric capacities ranging from $1 \mathrm{~kW}$ to $5 \mathrm{~kW}$ and electric generation efficiencies ranging from $10 \%$ to $25 \%$. For the highest electric efficiency, the primary energy saved increases as the output of the unit increases, whereas for the lowest electric efficiency, the primary energy saved is nearly independent of the unit's size. This is in line with the reverse-metering results discussed above.

It may be useful to compare the primary energy savings for the $1 \mathrm{~kW}$ system with reverse metering, as shown in Figure 3-12, with the results shown in Figure 2-2 of the previous section. 
The latter curves, without reverse metering, reach their maxima for power outputs exceeding 1 $\mathrm{kW}$. The primary energy savings values at these higher outputs, without reverse metering, are not very different from those for the $1 \mathrm{~kW}$ system with reverse metering. This is consistent with the fact that for the $1 \mathrm{~kW}$ system there is little reverse metering even when that is allowed.

Figure 3-13 shows the results for Long Island, which are very similar, the main difference being the somewhat lower values of primary energy savings for similar system parameters.

In sum, the $1 \mathrm{~kW}$ space-heating/DHW systems have characteristics similar to the DHW-only systems, in that reverse metering makes little difference in the results. In contrast, the highercapacity space-heating/DHW systems with reverse metering are dramatically different from those without.

\section{Consumer Cost Savings}

Any definitive cost analysis will need to take into account technology-related details that are glossed over in this baseline analysis. In addition, cost comparisons will depend critically on the ratio between the price consumers pay for electricity and what they pay for fuel delivered to the home. Nevertheless, it may be illuminating to obtain some benchmark results, as long as these are regarded as very preliminary indications of what the final results would be under detailed assumptions of equipment performance and possibly complicated pricing structures that may attend different electric service categories.

Information from the New York State Energy Research and Development Authority's Web site gave the following recent average values for residential energy prices in New York State:

- Electricity: \$0.194 per kWh (as of June 2008)

- Fuel Oil: $\$ 3.35$ per gallon, equivalent to $\$ 23.93$ per MBtu (as of June 2008)

- Natural Gas: \$18.32 per MBtu (as of October 2008)

These prices, particularly that for fuel oil, have been fluctuating rapidly in the past year, and it would be foolhardy to make predictions concerning the future that would likely become obsolete in a matter of months. Instead, for the purposes of the baseline analysis, it was decided to use round-number benchmarks reasonably close to the above values. These are:

- Electricity: $\$ 0.20$ per kWh

- Fuel (whether oil or gas): $\$ 20.00$ per MBtu

These choices incidentally are close to equalizing the cost of site-delivered fuel to that of the underlying fuel used to produce electricity. That is, at 33\% efficiency at the power plant, the consumer cost of the electricity, if pro-rated to the fuel used by the utility, works out to $\$ 19.33$ per MBtu. Of course, the utility pays nowhere near this amount for its fuel, especially if it is coal or uranium, or for that matter, even if it is oil, but this comparison does predict that the cost savings numbers will be roughly proportional to the primary-energy savings numbers found earlier. At this stage of the analysis, that is perhaps a blessing.

These figures show dramatically increased cost savings when a $3-\mathrm{kW}$ or $5-\mathrm{kW}$ system with $20 \%$ to $25 \%$ electric generation efficiency is applied to both space and water heating and is reverse 
metered. It perhaps bears repeating, however, that this assumes a situation in which reverse metering is allowed for these systems.

\section{Conclusions}

Conclusions with respect to storage capacity were:

- For the DHW-only system, the primary energy savings was essentially independent of thermal storage capacity over a fourfold range.

- For the space-heating/DHW system, the primary energy savings depended only weakly on thermal storage capacity.

Conclusions with respect to reverse metering were:

- For the DHW-only systems, reverse metering had no effect on primary energy savings, since no electric energy was sent back into the grid.

- For combined space-heating/DHW systems of $1 \mathrm{~kW}$ capacity, reverse metering had only a minor effect on primary energy savings, since little electric energy was sent back to the grid.

- For combined space-heating/DHW systems with low electric efficiency (10\%) reverse metering had little effect on primary energy savings, since little electric energy was sent back to the grid regardless of the electric power output of the micro-CHP unit.

- For combined space-heating/DHW systems of $3 \mathrm{~kW}$ to $5 \mathrm{~kW}$ capacity and also high electric efficiency $(20 \%-25 \%)$, reverse metering significantly increased primary energy savings. Most of the reverse-metered electric energy was sent back to the grid in the cold months (November through March), when most U.S. electric utilities have little or no need for excess generating capacity.

The main conclusion with respect to cost savings was:

- For benchmark fuel and electricity prices to the consumer of $\$ 20$ per MBtu and $\$ 0.20$ per $\mathrm{kWh}$, respectively, annual energy cost savings were nearly proportional to the primary energy savings. 


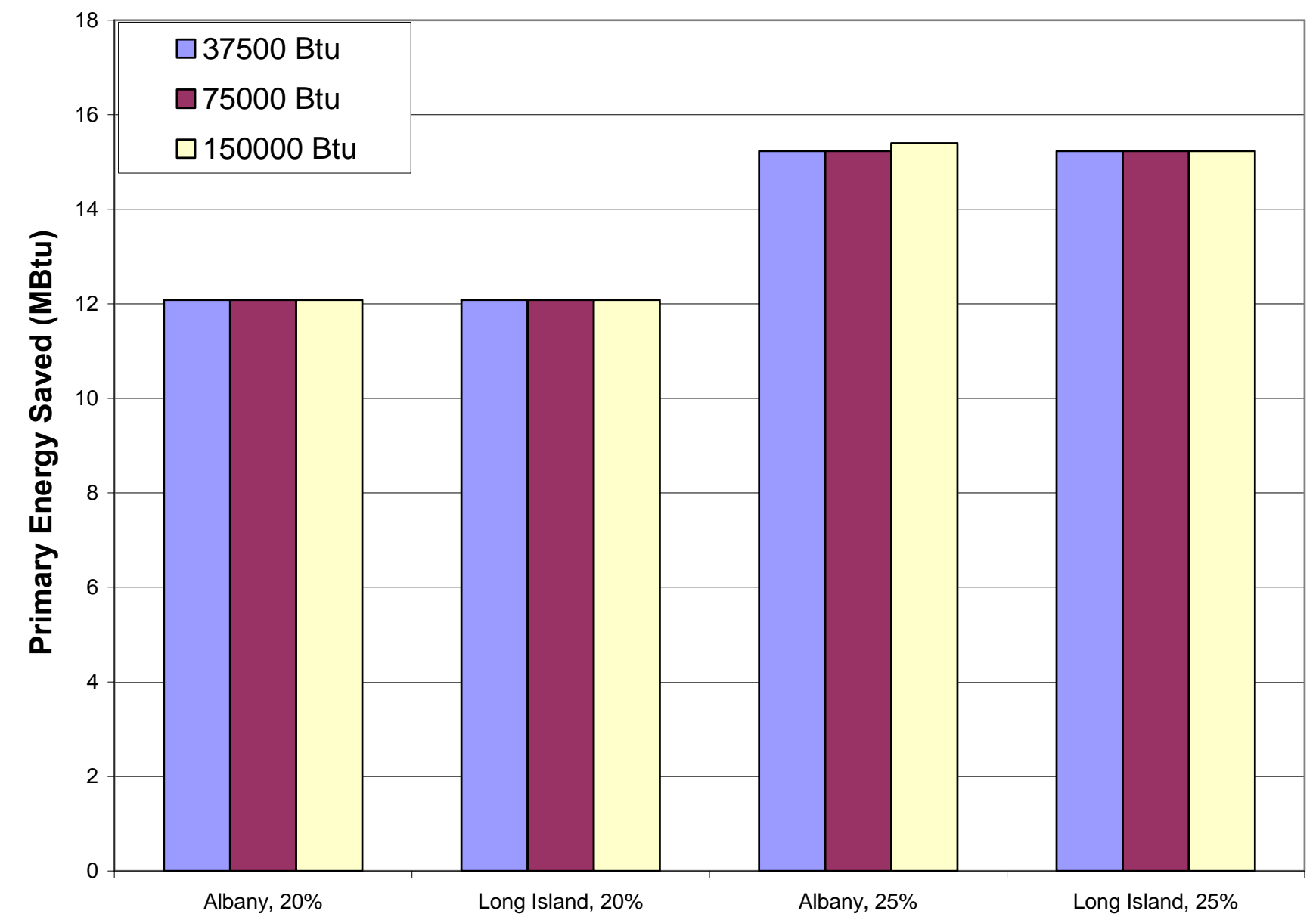

Figure 3-1. Impact of storage capacity on energy savings for DHW-only system, by location and electric efficiency 
EFFECT OF DHW STORAGE SIZE IN ALBANY

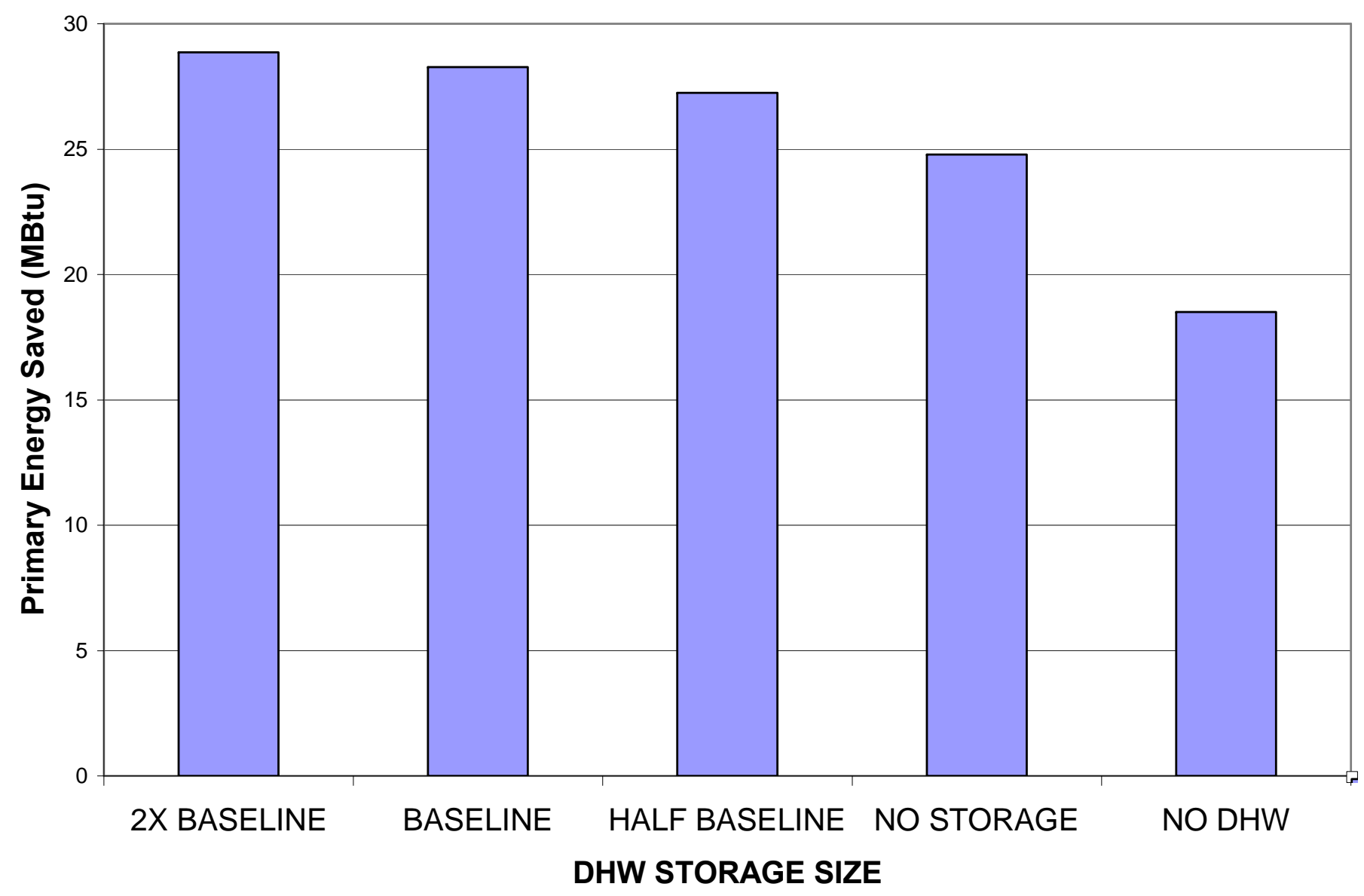

Figure 3-2. Effect of DHW storage capacity in Albany, for combined space heating/DHW system 


\section{EFFECT OF STORAGE SIZE ON LONG ISLAND}

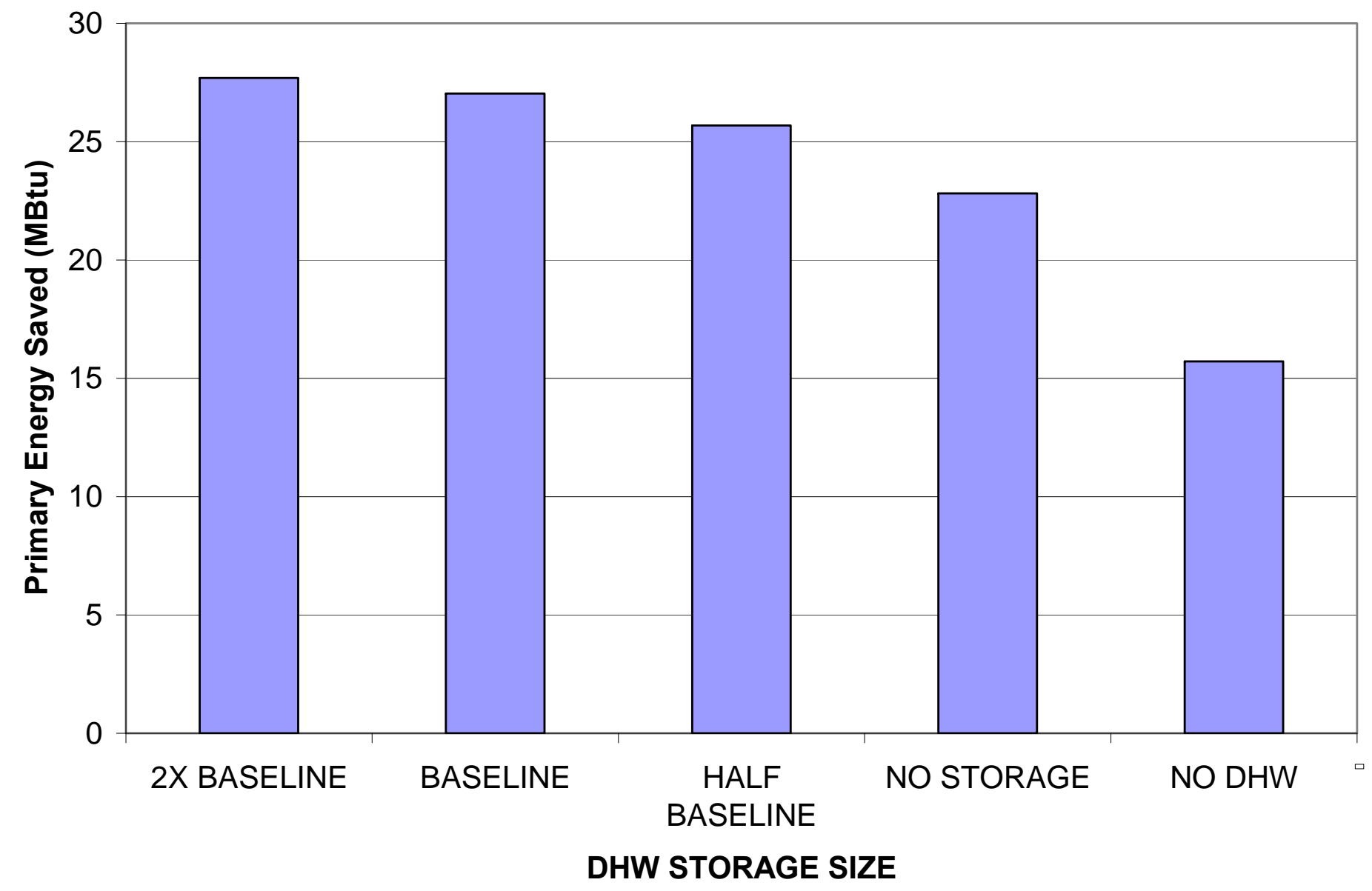

Figure 3-3. Effect of DHW storage capacity on Long Island, for combined space heating/DHW system 
REVERSE METERING IN ALBANY -- 25\% ELECTRIC EFFICIENCY SYSTEM

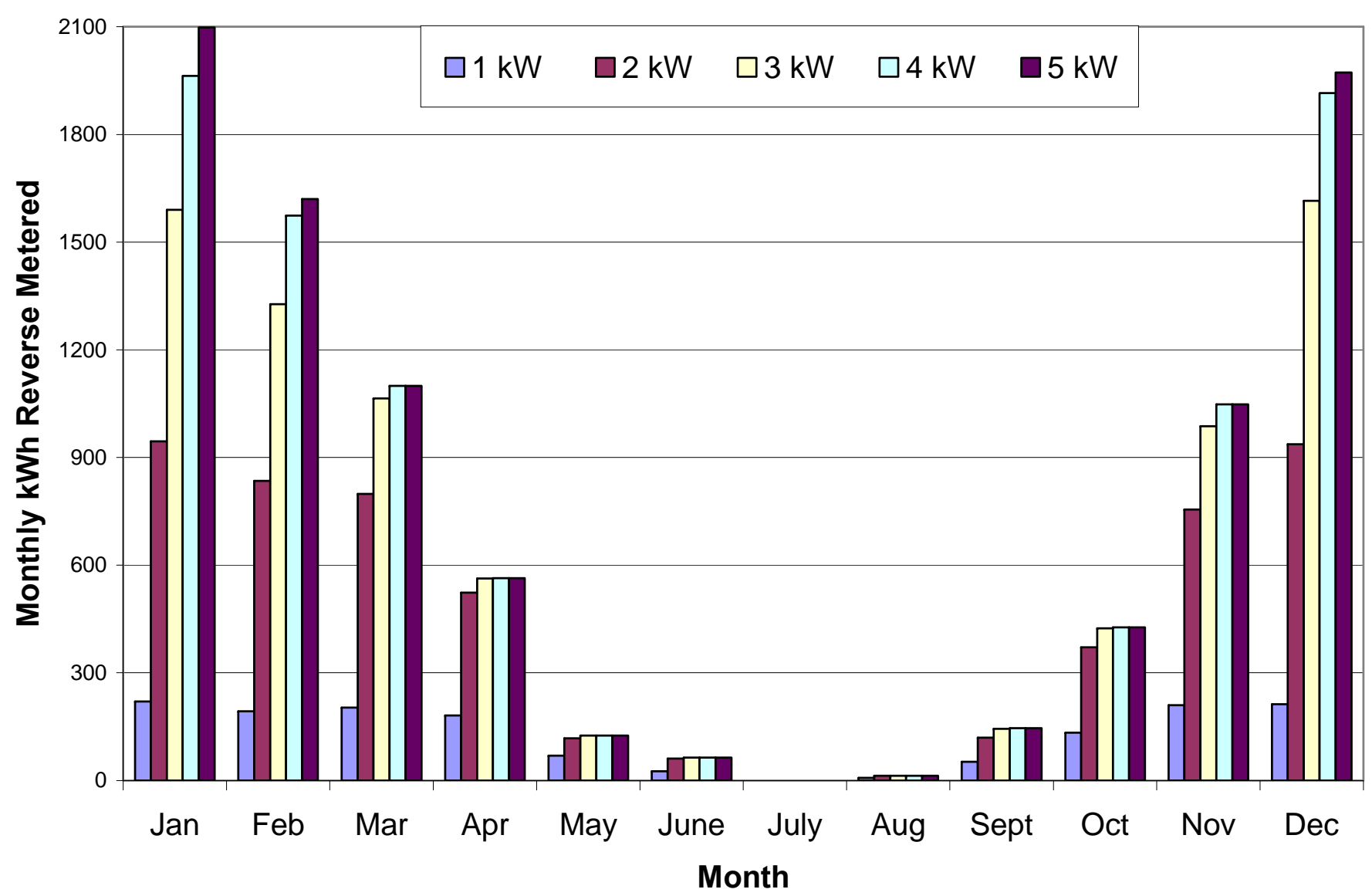

Figure 3-4. Monthly electric kilowatt-hours reverse metered in Albany - 25\% electric efficiency system 


\section{REVERSE METERING IN ALBANY -- 20\% ELECTRIC EFFICIENCY SYSTEM}

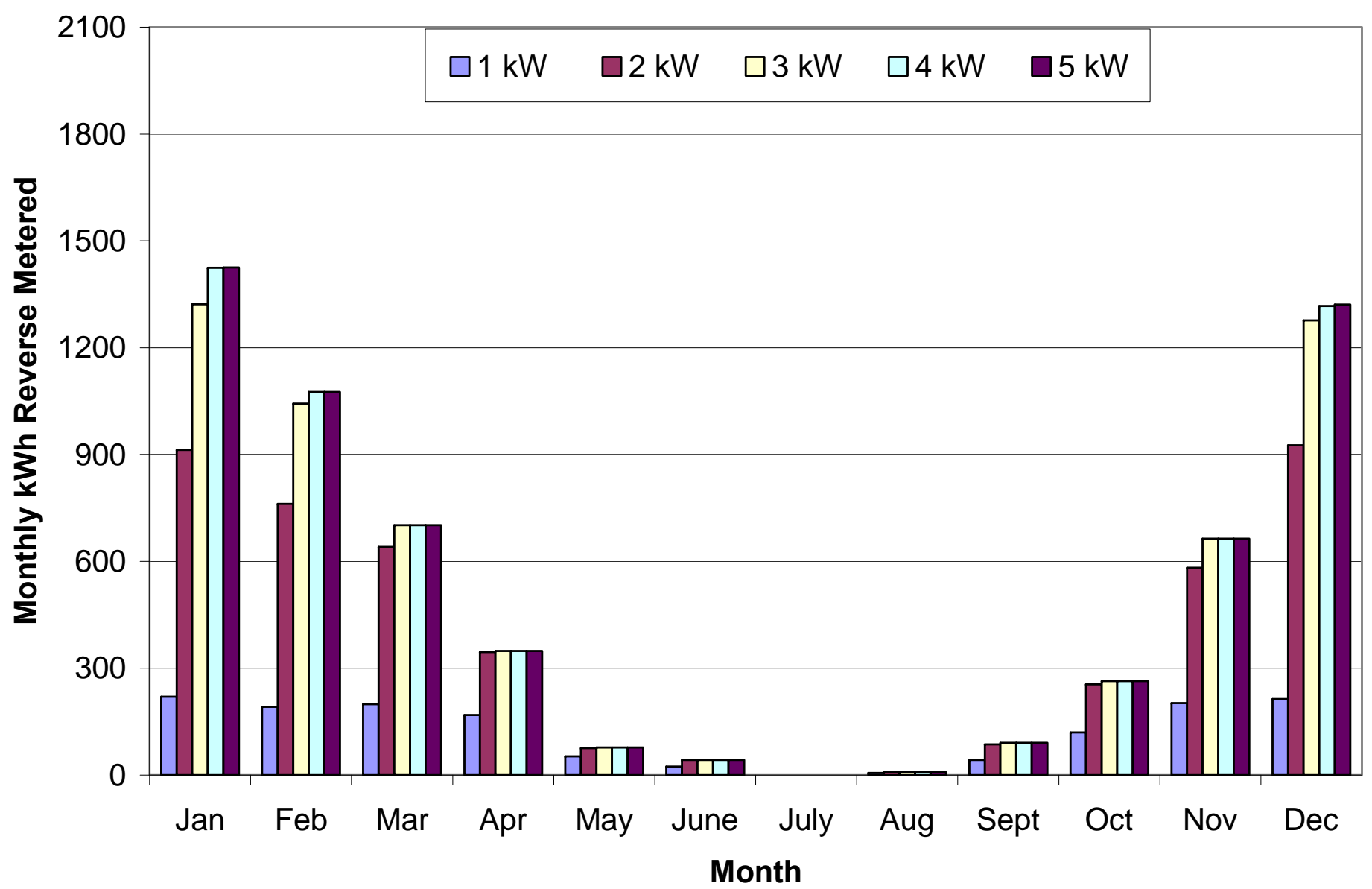

Figure 3-5. Monthly electric kilowatt-hours reverse metered in Albany - 20\% electric efficiency system 


\section{REVERSE METERING IN ALBANY -- 15\% ELECTRIC EFFICIENCY SYSTEM}

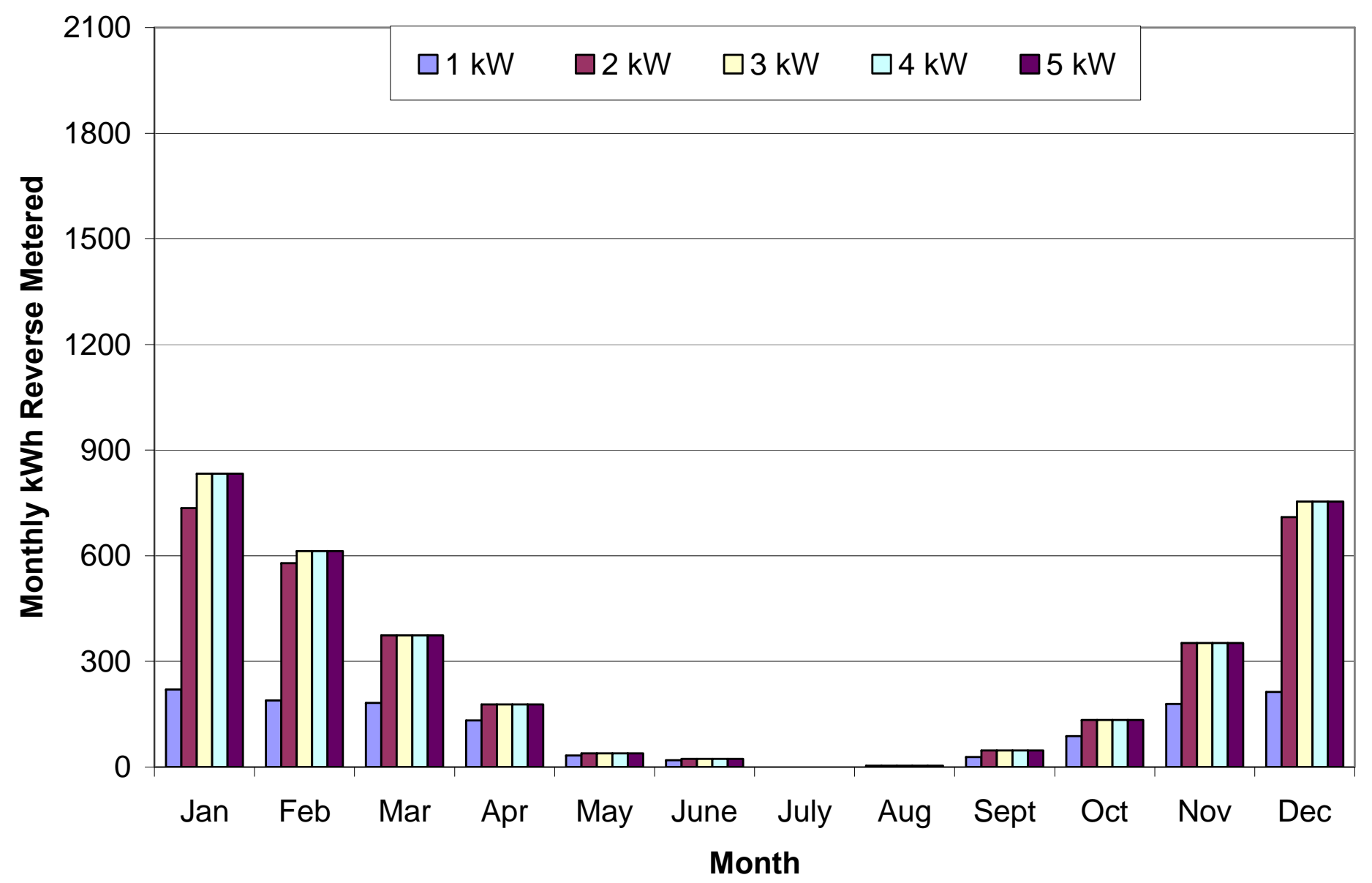

Figure 3-6. Monthly electric kilowatt-hours reverse metered in Albany - 15\% electric efficiency system 
REVERSE METERING IN ALBANY -- 10\% ELECTRIC EFFICIENCY SYSTEM

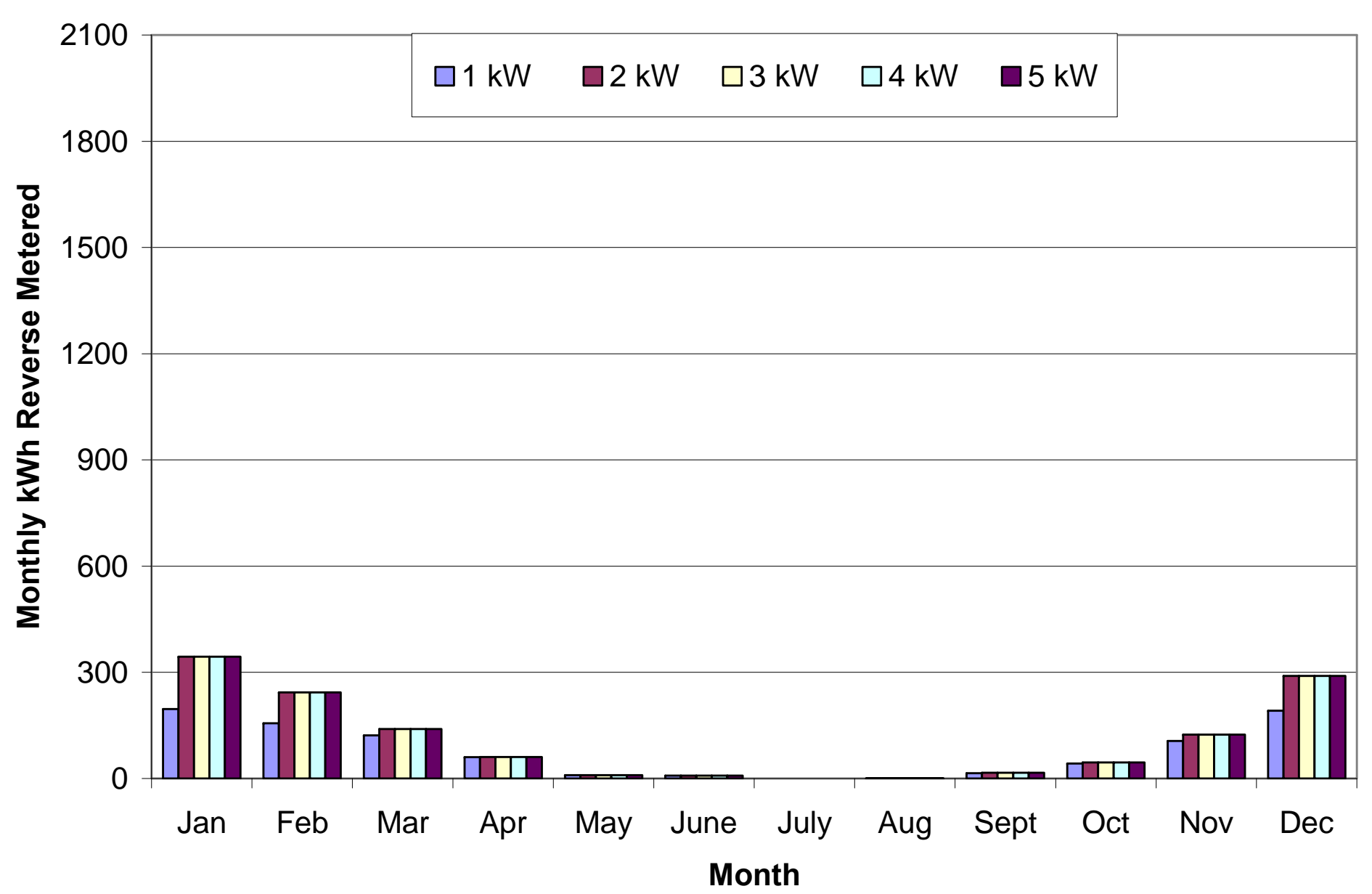

Figure 3-7. Monthly electric kilowatt-hours reverse metered in Albany - 10\% electric efficiency system 
REVERSE METERING LONG ISLAND -- 25\% ELECTRIC EFFICIENCY SYSTEM

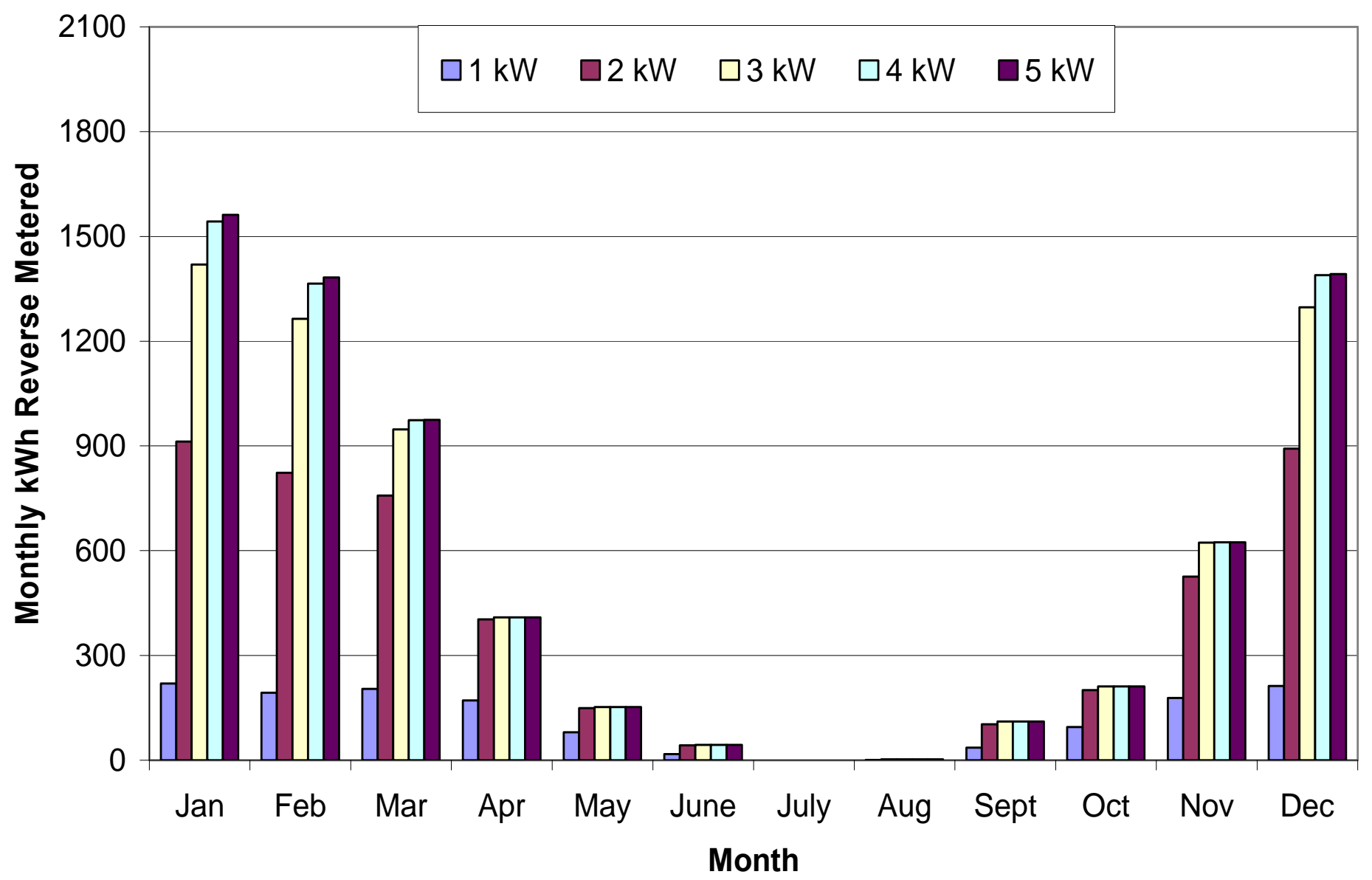

Figure 3-8. Monthly electric kilowatt-hours reverse metered on Long Island - 25\% electric efficiency system 
REVERSE METERING LONG ISLAND -- 20\% ELECTRIC EFFICIENCY SYSTEM

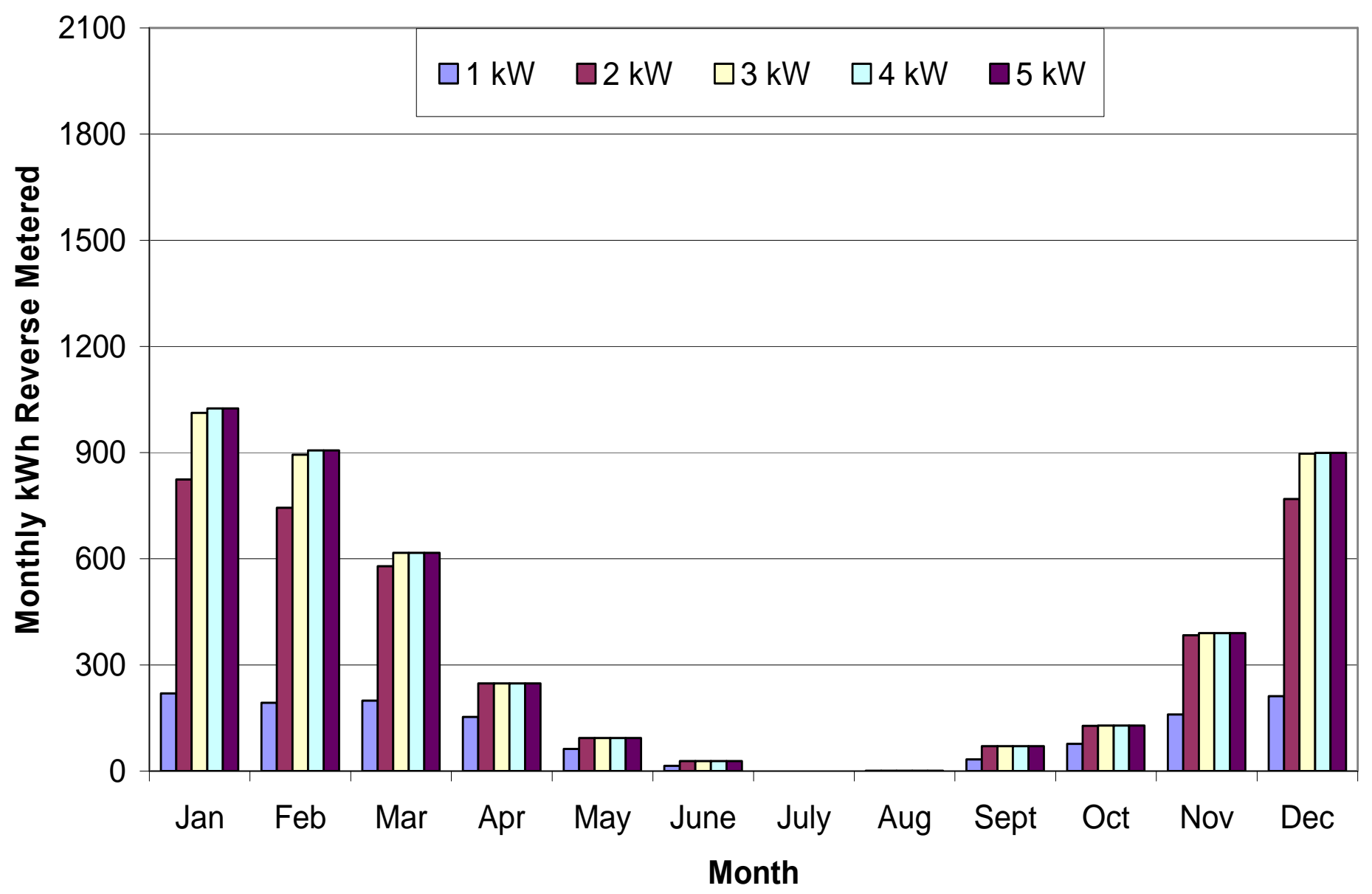

Figure 3-9. Monthly electric kilowatt-hours reverse metered on Long Island - 20\% electric efficiency system 
REVERSE METERING LONG ISLAND -- 15\% ELECTRIC EFFICIENCY SYSTEM

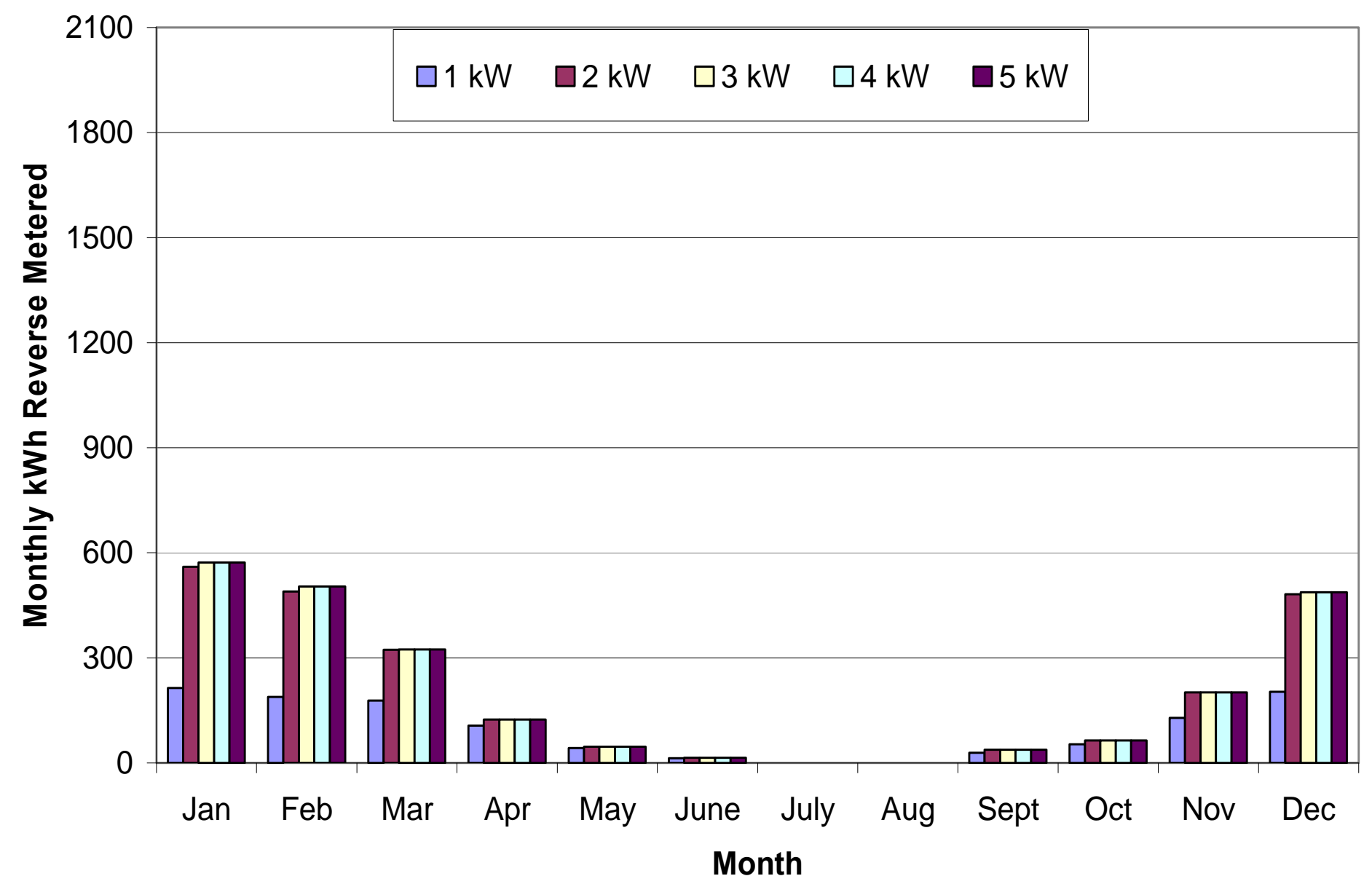

Figure 3-10. Monthly electric kilowatt-hours reverse metered on Long Island - 15\% electric efficiency system 


\section{REVERSE METERING LONG ISLAND -- 10\% ELECTRIC EFFICIENCY SYSTEM}

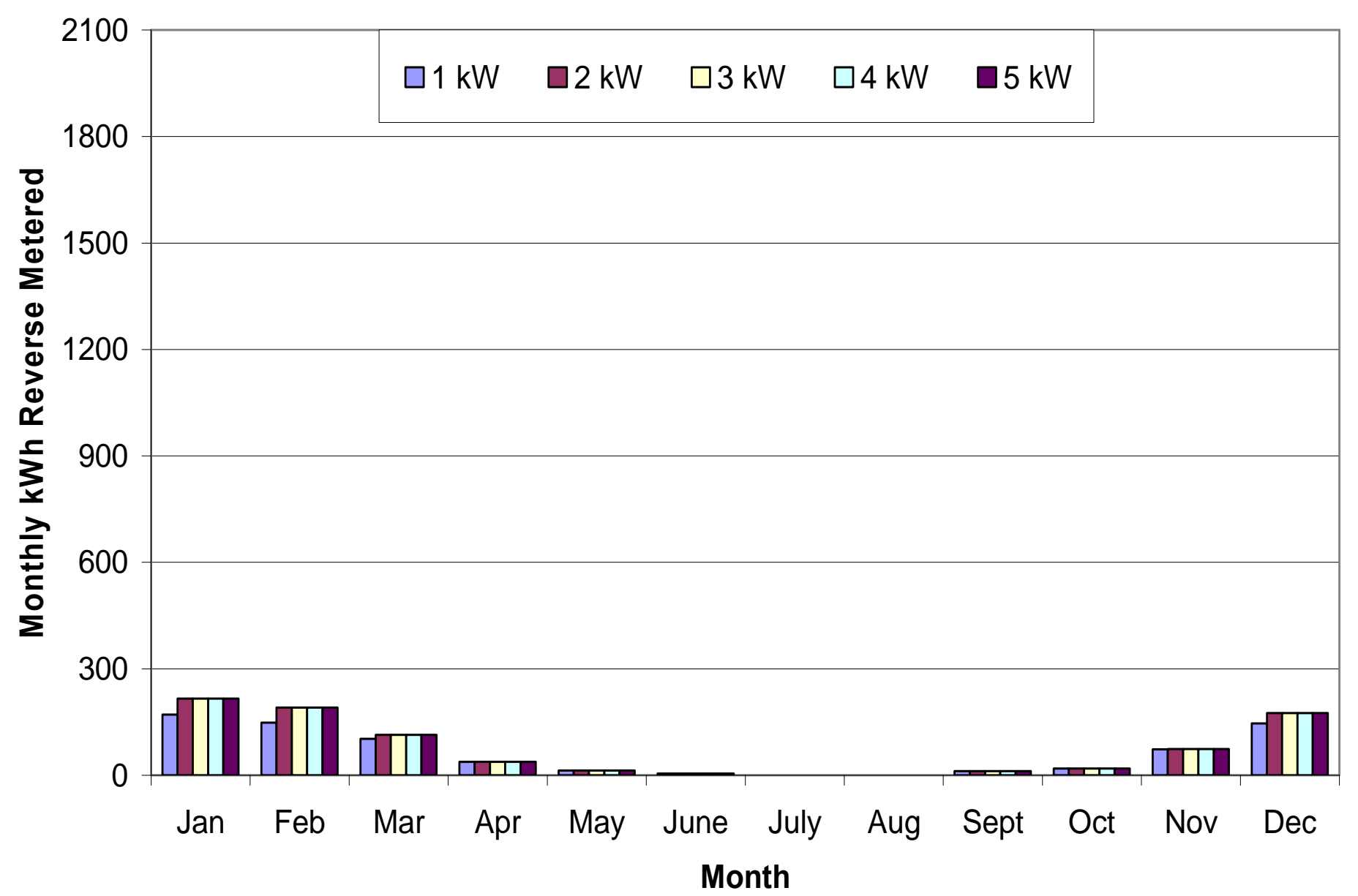

Figure 3-11. Monthly electric kilowatt-hours reverse metered on Long Island - 10\% electric efficiency system 


\section{HEATING AND DHW IN ALBANY WITH REVERSE METERING}

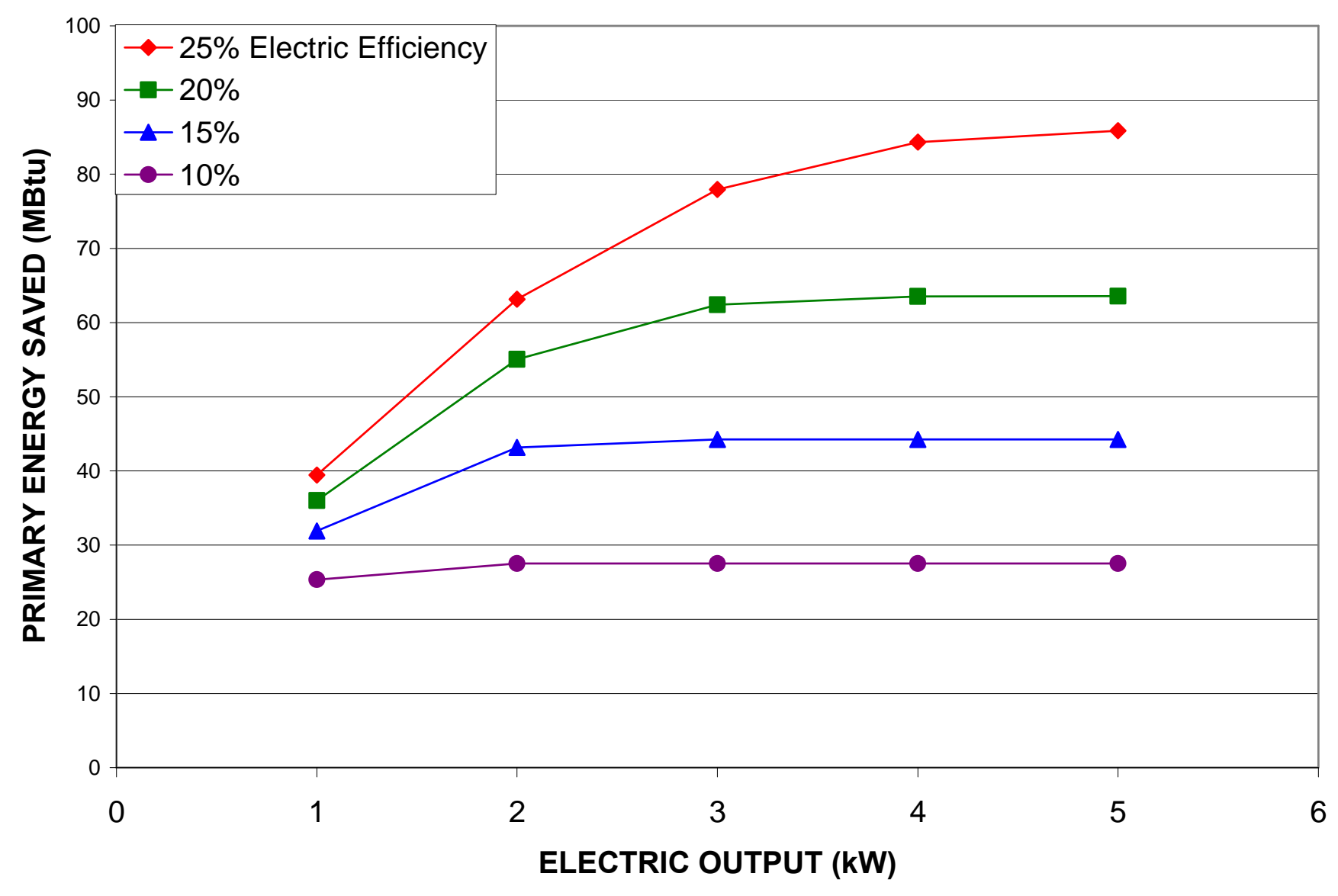

Figure 3-12. Primary energy savings for space-heating/DHW systems with reverse metering in Albany 


\section{HEATING AND DHW ON LONG ISLAND WITH REVERSE METERING}

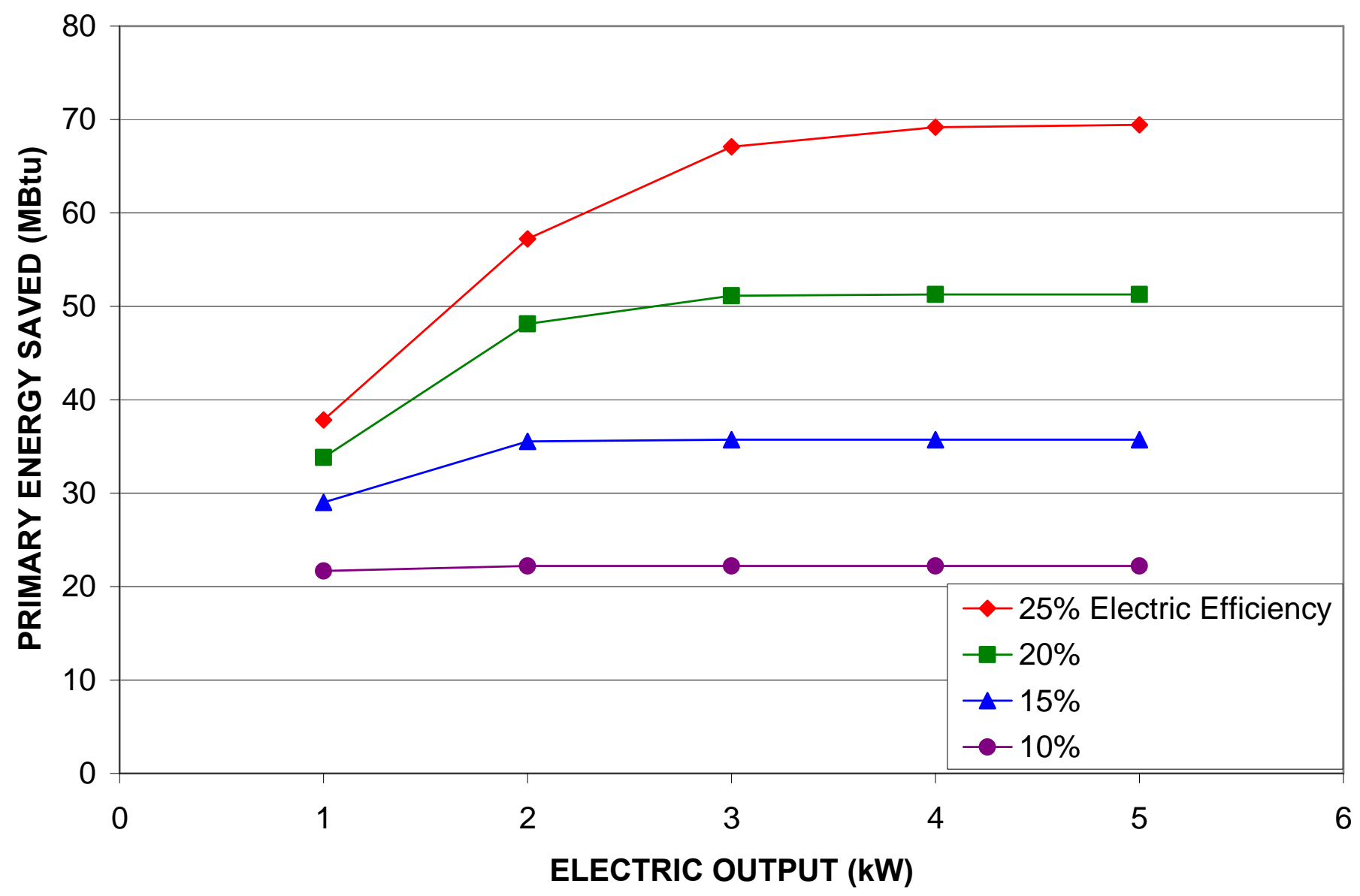

Figure 3-13. Primary energy savings for space-heating/DHW systems with reverse metering on Long Island 


\section{ENERGY COST SAVINGS IN ALBANY}

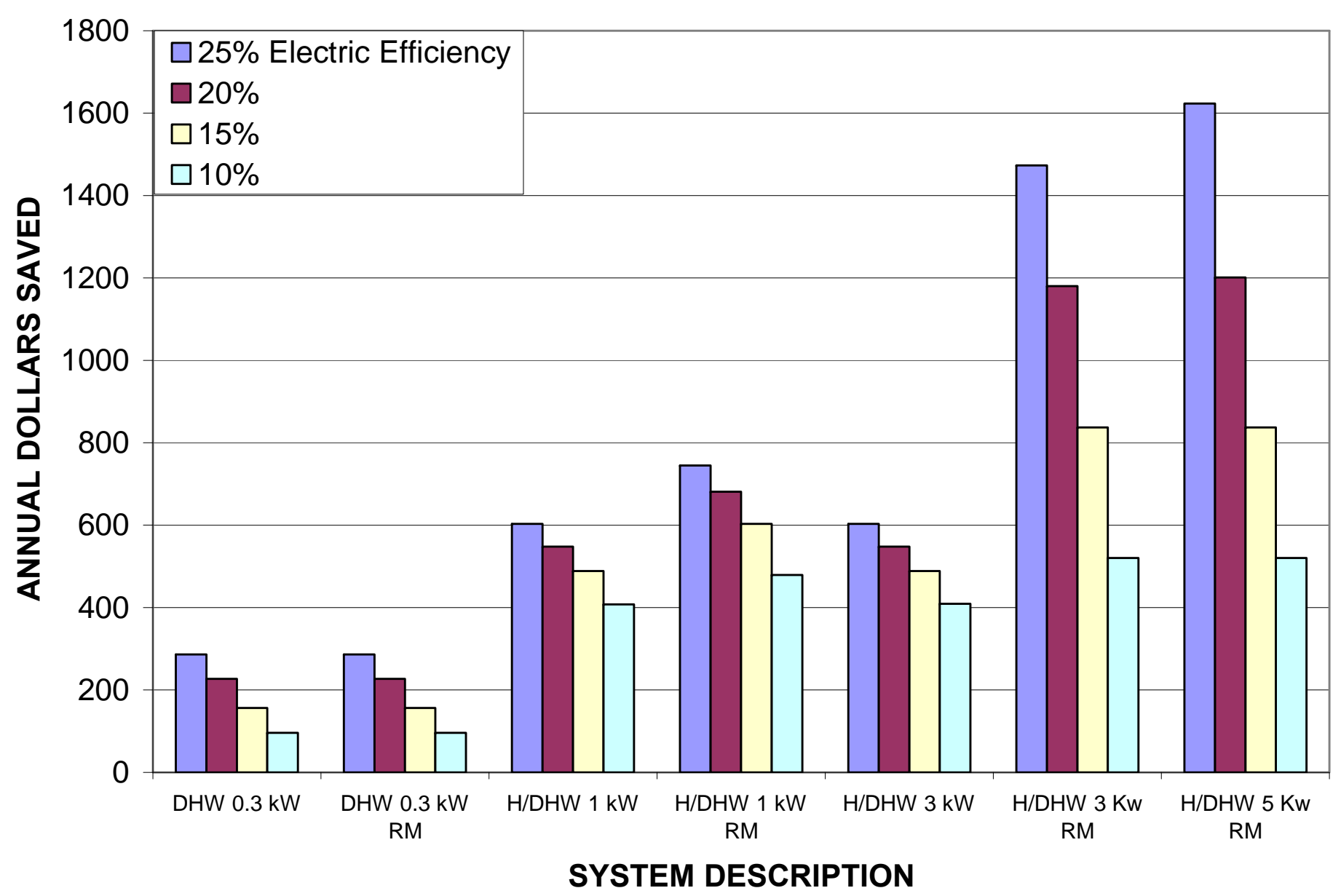

Figure 3-14. Consumer cost savings on purchased energy in Albany. $\mathrm{DHW}=$ hot-water only. $\mathrm{H} / \mathrm{DHW}=$ heat and hot water. $\mathrm{RM}=$ reverse metering. 


\section{ENERGY COST SAVINGS ON LONG ISLAND}

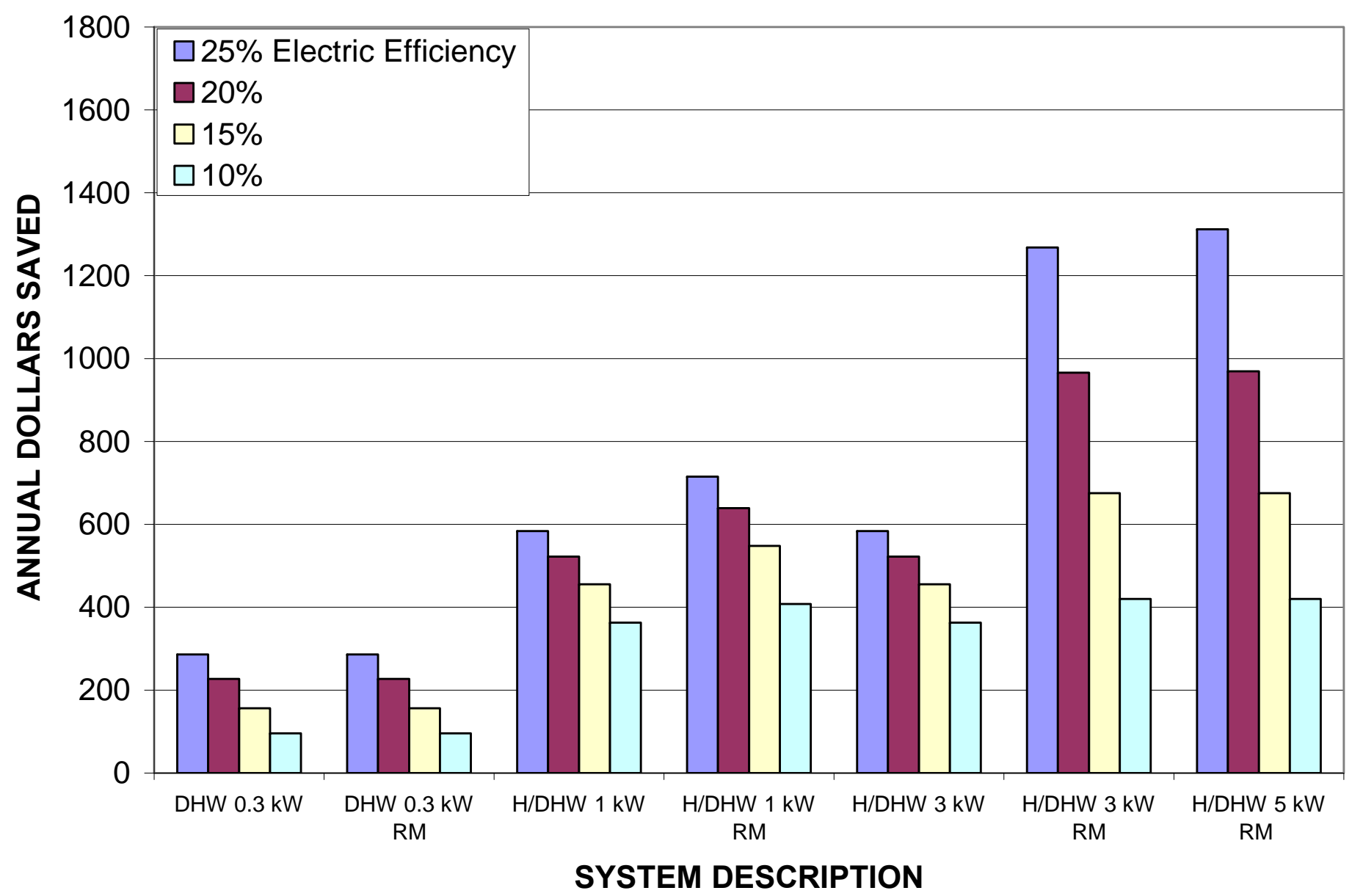

Figure 3-15. Consumer cost savings on purchased energy on Long Island. $\mathrm{DHW}=$ hot-water only. $\mathrm{H} / \mathrm{DHW}=$ heat and hot water. $\mathrm{RM}=$ reverse metering. 


\section{IMPACT OF REDUCED TOTAL EFFICIENCY}

The baseline analyses were all done assuming that the total efficiency (electrical plus thermal) of the mCHP system is $85 \%$. It was natural then to ask how much the overall merit of the mCHP system would be affected if the total efficiency were less than $85 \%$.

Part of the motivation for this question was the realization that it might be difficult and/or costly to extract both the jacket heat and the exhaust heat from a small Diesel engine. In that event, would there still be a case for developing the product?

To answer this question, two approaches were taken:

- A "quick analysis" based solely on the amount of fuel needed by a conventional system to provide the same electrical and thermal energy as the mCHP system.

- A redo of some of the baseline analyses, using the Energy 10 building loads, with lower assumed total efficiencies than the baseline $85 \%$.

\section{Quick Analysis}

Let us make the following notational definitions:

$\eta_{\text {elec }}=$ Electrical efficiency of the mCHP system

$\eta_{\text {ther }}=$ Thermal efficiency of the mCHP system

$\eta_{\text {util }}=$ Efficiency of electric power production by the utility

$\eta_{\text {furn }}=$ Efficiency of heat production by the furnace

One can then state the following relationships:

- One unit of fuel into the mCHP system produces $\eta_{\text {elec }}$ units of electricity and $\eta_{\text {ther }}$ units of heat.

- To produce one unit of electricity, the utility uses $1 / \eta_{\text {util }}$ units of fuel.

- To produce one unit of heat, the furnace uses $1 / \eta_{\text {furn }}$ units of fuel.

The total fuel use by the conventional system (utility and furnace) to produce the same energy that the mCHP system produces using one unit of fuel is then $\eta_{\text {elec }} / \eta_{\text {util }}+\eta_{\text {ther }} / \eta_{\text {furn }}$.

If this quantity is greater than unity, the mCHP system saves fuel, assuming that the heat and electricity produced by the mCHP are both fully utilized. This quantity, which we will call the "Efficiency Ratio" can serve as a best-case figure of merit for the mCHP system, at least as far as fuel use is concerned. Actual performance of the mCHP may be less if any of the electricity or the heat is not used. In our baseline analyses, we assumed a control strategy that insured full usage of the energy produced by the mCHP, either by limiting its fractional ontime to be consistent with full utilization of both energy forms (in the case of no reverse metering) or by controlling on the thermal load and sending any excess electric energy back to the grid (reversemetering case). 
Results for some plausible values of the mCHP parameters are shown in Table 4-1. Here it is assumed, as in the baseline analyses discussed above, that the electric utility's efficiency is $33 \%$ and the on-site furnace has an efficiency of $85 \%$.

Table 4-1. Efficiency Ratio: Fuel used by electric utility plus on-site furnace to produce the same electric and thermal energy as the mCHP system using one unit of fuel. Electric utility efficiency $=0.33$. On-site furnace efficiency $=0.85$

\begin{tabular}{|l|r|r|r|r|r|r|r|r|}
\hline $\begin{array}{c}\text { mCHP Parameters } \\
\text { Total Efficiency }\end{array}$ & 0.85 & 0.80 & 0.75 & 0.70 & 0.65 & 0.60 & 0.55 & 0.50 \\
Electrical Efficiency & 1.46 & 1.40 & 1.35 & 1.29 & 1.23 & 1.17 & 1.11 & 1.05 \\
\hline 0.25 & 1.37 & 1.31 & 1.25 & 1.19 & 1.14 & 1.08 & 1.02 & 0.96 \\
\hline 0.20 & 1.28 & 1.22 & 1.16 & 1.10 & 1.04 & 0.98 & 0.93 & 0.87 \\
\hline 0.15 & 1.19 & 1.13 & 1.07 & 1.01 & 0.95 & 0.89 & 0.83 & 0.77 \\
\hline 0.10 & & & &
\end{tabular}

From this table, one can make the following generalizations. If the total efficiency is degraded because of decreasing electrical efficiency, with the thermal efficiency held constant (red numerals in Table 4-1), the efficiency ratio declines rapidly. If the electrical efficiency is held constant while the thermal efficiency decreases (rows across Table 4-1), the efficiency ratio declines more slowly.

Overall, judging simply from these numbers, it appears that one might be able to live with a somewhat lower thermal efficiency than we have assumed as long as the electrical efficiency remains high, but even at $25 \%$ electrical efficiency, the overall performance as measured by efficiency ratio starts to look unappealing as the total efficiency drops below $75 \%$.

\section{Analysis Using Energy-10 Loads}

We then re-ran some of the baseline analyses using lower values for the total efficiency than the $85 \%$ used up to this point. Cases were studied both with and without reverse metering in Albany and on Long Island. Total efficiency values of $85 \%$ (the baseline), $70 \%$, and $55 \%$ were considered. The electrical efficiency was varied from $25 \%$ down to $10 \%$ in 5 percentage-point increments. The thermal efficiency was set to the difference between the total and electrical efficiency in each case.

\section{Cases Without Reverse Metering}

An mCHP system with an electrical output of $1 \mathrm{~kW}$ was used as a base case. This value was chosen because in the previous analyses it was found that the energy savings did not increase very much when the output was increased above this value. (See Figures 2-3 and 2-4.)

Figure 4-1, for Albany, tells a tale that is more or less repeated in the rest of the figures. In this figure, each group of bars shows what happens, for any given electric efficiency, when the thermal efficiency (and hence the total efficiency) declines in increments of 15 percentage points. 
When the thermal efficiency declines (and along with it the total efficiency), the primary energy savings values plummet. For the system with $25 \%$ electric efficiency, the energy savings declines by a third when the total efficiency goes from $85 \%$ to $70 \%$, and by another third when the total efficiency drops to $55 \%$.

For a system with $20 \%$ electric efficiency, the situation is even worse. Here, the energy savings declines by half when the total efficiency goes from $85 \%$ to $70 \%$, and almost to zero at $55 \%$ total efficiency.

For the $15 \%$ and $10 \%$ electric efficiency cases, the energy savings actually goes negative over the same range of total efficiencies.

If these results are representative of other cases, it appears to be essential to keep the total efficiency near the thermal efficiency of the competing furnace. One may be able to live with a less than hoped-for electrical efficiency, but not with a severe deficit in total efficiency.

Figures 4-2 and 4-3 show comparable results for the $2 \mathrm{~kW}$ and $3 \mathrm{~kW}$ cases. They are nearly identical to Figure 4-1. For completeness, a smaller $0.5 \mathrm{~kW}$ system was modeled. Aside from lower energy savings in each case, the results are similar.

The Long Island results are shown in Figures 4-5 through 4-8. Aside from somewhat lower energy savings in each case, due to the lower heating loads on Long Island, the qualitative character of the results is almost exactly the same as in Albany.

\section{Reverse Metering}

The next question was whether reverse metering would have any effect on these results. Beginning with the $1 \mathrm{~kW}$ (electric) system in Albany, Figure 4-9 shows results that are very similar to those of Figure 4-1, with energy savings values that are slightly larger. This should not be surprising, since we found that the $1 \mathrm{~kW}$ system utilized relatively little reverse metering (Note that the scale of Figure 4-9 has been changed from that of the previous set of charts so that it can be compared with following figures.)

As the electrical output of the mCHP system is increased to $3 \mathrm{~kW}$ and then to $5 \mathrm{~kW}$, it can be seen that the percentage reduction in energy savings, when the total efficiency drops to $70 \%$, is less than in the $1 \mathrm{~kW}$ case or any of the cases without reverse metering. This can be seen in Figures 4-10 and 4-11.

The Long Island cases are similar, as shown in Figures 4-12 through 4-14.

\section{Impact of Total Efficiency Reduction}

It may be of interest to look at how the "hit" one takes in sustaining a decline in total efficiency from $85 \%$ to $70 \%$ depends on the system type. Let us focus on the $25 \%$ electrical efficiency 
case, since that is the case where this penalty is least severe. For lower electrical efficiencies, the impact of reducing the total efficiency becomes ever more onerous.

The following table compares the differences between the energy savings at $85 \%$ total efficiency and $70 \%$ total efficiency for four cases where the electrical efficiency is held constant at $25 \%$ :

- $1 \mathrm{~kW}$ electric output without reverse metering

- $1 \mathrm{~kW}$ electric output with reverse metering

- $3 \mathrm{~kW}$ electric output with reverse metering

- $5 \mathrm{~kW}$ electric output with reverse metering

(The reason for not considering higher-output cases without reverse metering is that they are nearly the same as the $1 \mathrm{~kW}$ case.)

Having defined these cases, let us look at both the absolute declines in energy savings (in energy units, million Btu) and the percentage declines:

Decrease in energy savings when total efficiency declines from $85 \%$ to $70 \%$.

\begin{tabular}{|c|c|c|c|c|c|}
\hline \multirow{2}{*}{$\begin{array}{l}\text { Lecation } \\
\text { Electric }\end{array}$} & \multicolumn{2}{c|}{ Albany } & \multicolumn{2}{c|}{ Long Island } \\
Output $(\mathrm{kW})$ & $\begin{array}{l}\text { Reverse } \\
\text { Metering? }\end{array}$ & \multicolumn{2}{|c|}{$\begin{array}{c}\text { Energy Savings Decline } \\
\text { Absolute (MBtu) }\end{array}$} & \multicolumn{2}{c|}{$\begin{array}{c}\text { Energy Savings Decline } \\
\text { Absolute (MBtu) }\end{array}$} \\
\hline 1 & NO & 10.1 & $33 \%$ & 9.7 & $32 \%$ \\
\hline 1 & YES & 12.9 & $33 \%$ & 12.0 & $32 \%$ \\
\hline 3 & YES & 22.0 & $28 \%$ & 17.0 & $25 \%$ \\
\hline 5 & YES & 17.0 & $20 \%$ & 12.5 & $18 \%$ \\
\hline
\end{tabular}

This can be summarized as follows. For the systems with $25 \%$ electrical efficiency, when the total efficiency is reduced from $85 \%$ to $70 \%$, the impact on the energy savings is as follows (for both Albany and Long Island):

- For the $1 \mathrm{~kW}$ systems, the energy savings declines by about one-third;

- For the $3 \mathrm{~kW}$ systems, the energy savings declines by about one-fourth;

- For the $5 \mathrm{~kW}$ systems, the energy savings declines by about one-fifth.

Thus, for higher output systems with good electrical efficiency in which reverse metering is employed, it may be feasible to tolerate a somewhat lower than optimal total efficiency. For the rest of the cases, the motivation to keep the total efficiency as high as possible is extremely strong. 
TOTAL EFFICIENCY (Et) COMPARISON ALBANY

$1 \mathrm{~kW}$ MCHP NO REVERSE METERING

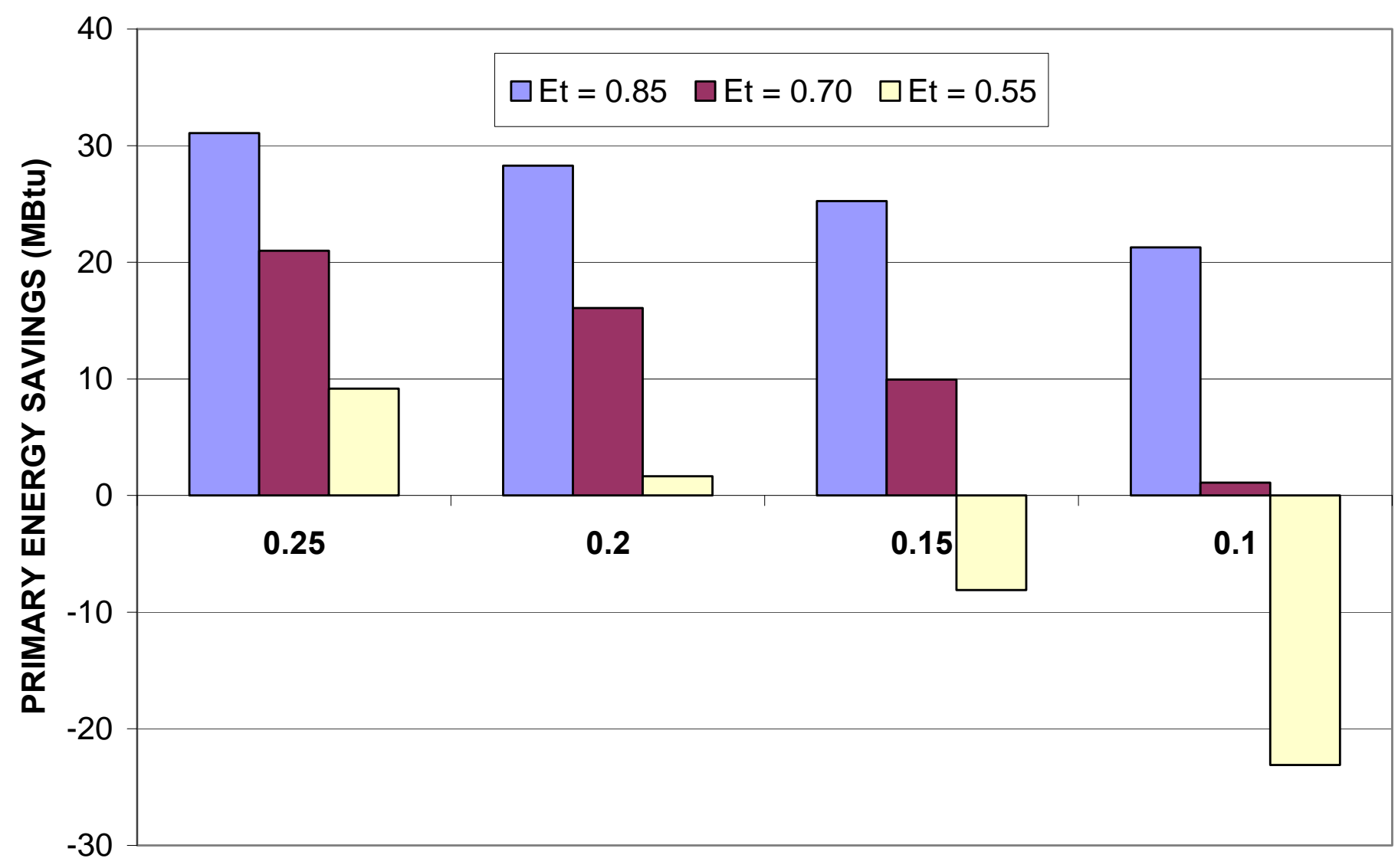

ELECTRICAL EFFICIENCY

Figure 4-1. Primary energy savings by total efficiency for 1-kW (electric) systems in Albany NO REVERSE METERING 
TOTAL EFFICIENCY (Et) COMPARISON ALBANY

2 kW MCHP NO REVERSE METERING

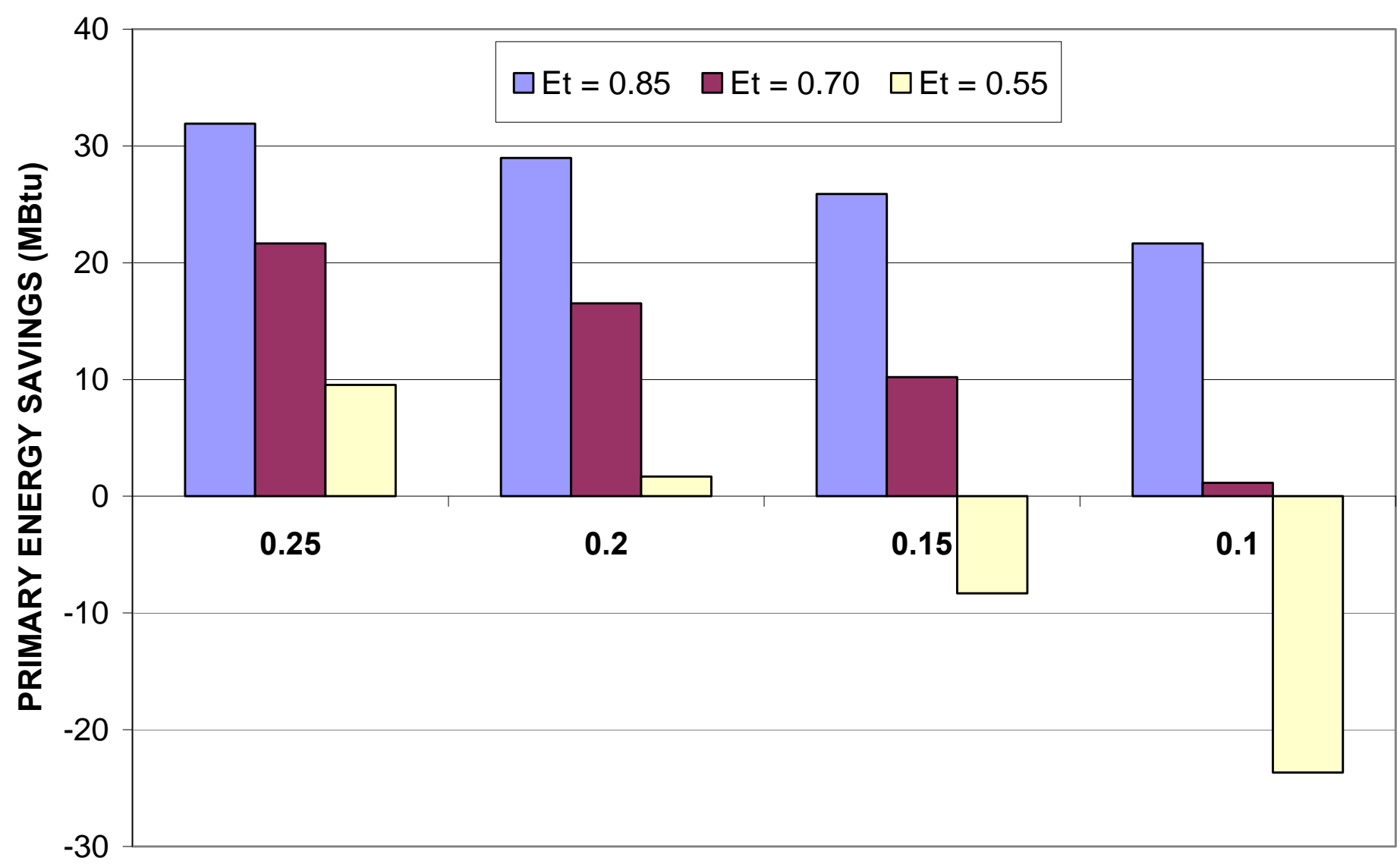

ELECTRICAL EFFICIENCY

Figure 4-2. Primary energy savings by total efficiency for 2-kW (electric) systems in Albany NO REVERSE METERING 
TOTAL EFFICIENCY (Et) COMPARISON ALBANY

3 kW MCHP NO REVERSE METERING

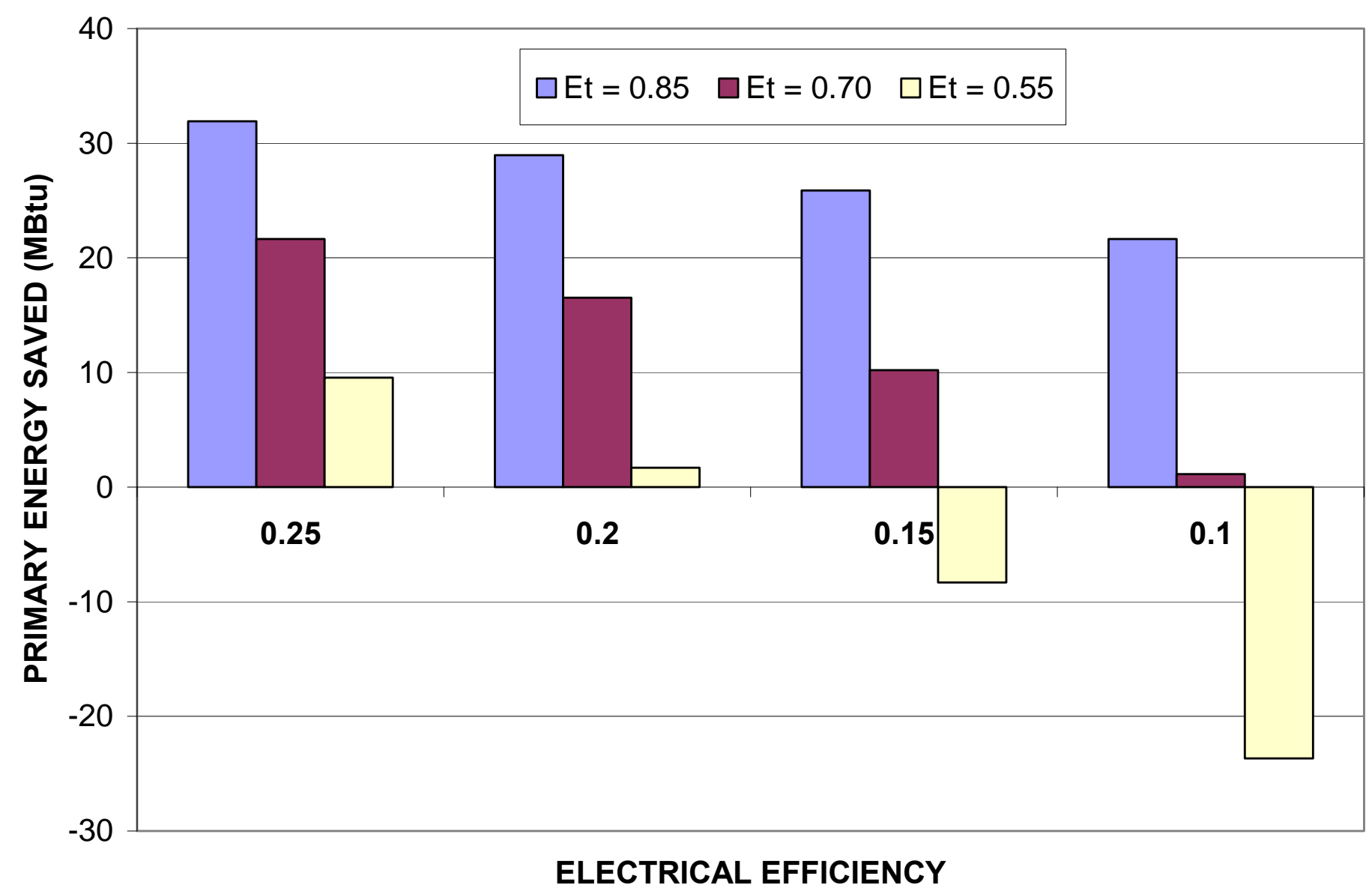

Figure 4-3. Primary energy savings by total efficiency for 3-kW (electric) systems in Albany NO REVERSE METERING 
TOTAL EFFICIENCY (Et) COMPARISON ALBANY

$0.5 \mathrm{~kW}$ MCHP NO REVERSE METERING

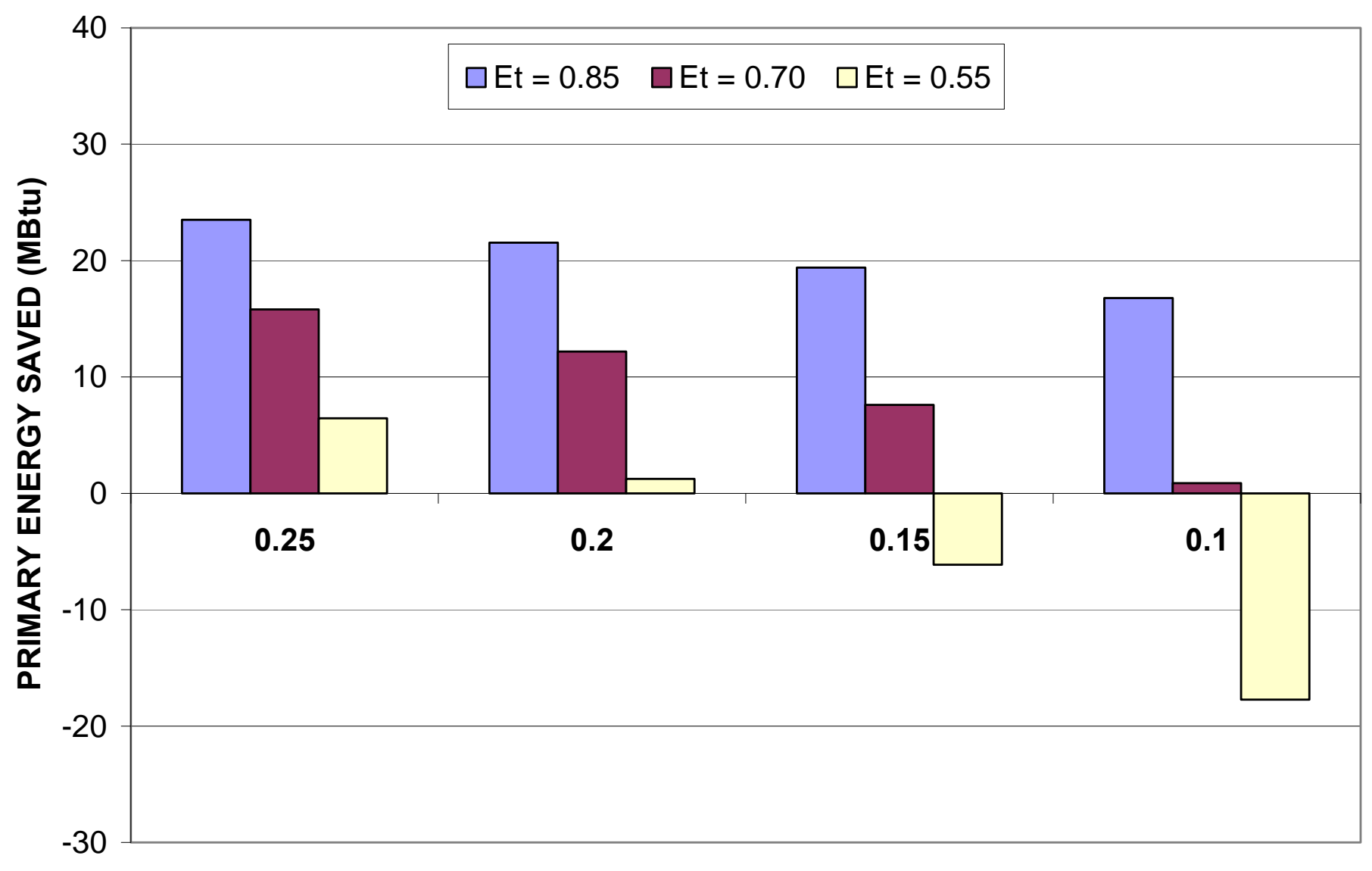

ELECTRICAL EFFICIENCY

Figure 4-4. Primary energy savings by total efficiency for $0.5-\mathrm{kW}$ (electric) systems in Albany NO REVERSE METERING 
TOTAL EFFICIENCY (Et) COMPARISON LONG ISLAND

$1 \mathrm{~kW}$ MCHP NO REVERSE METERING

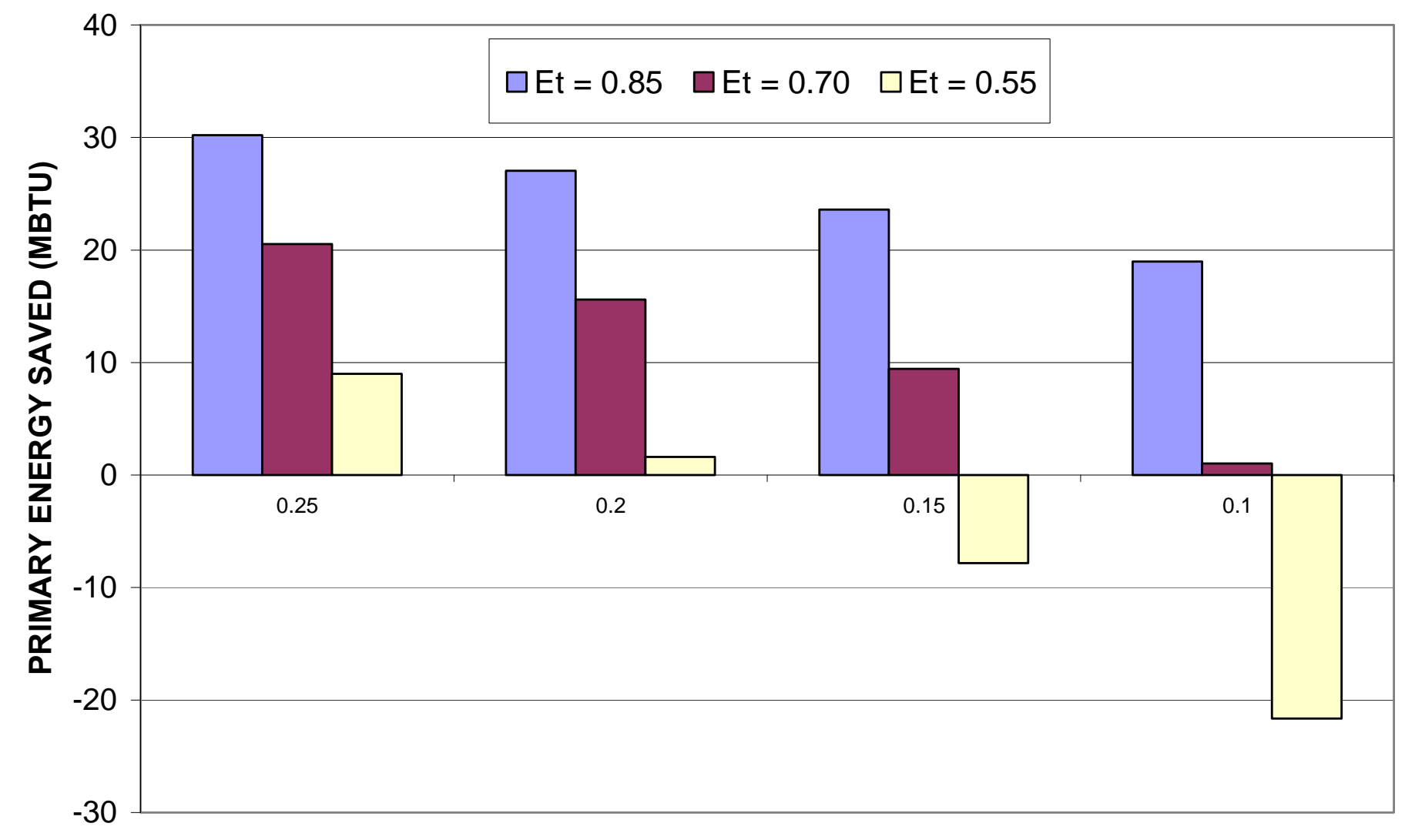

ELECTRICAL EFFICIENCY

Figure 4-5. Primary energy savings by total efficiency for 1-kW (electric) systems on Long Island NO REVERSE METERING 
TOTAL EFFICIENCY (Et) COMPARISON LONG ISLAND 2 kW MCHP NO REVERSE METERING

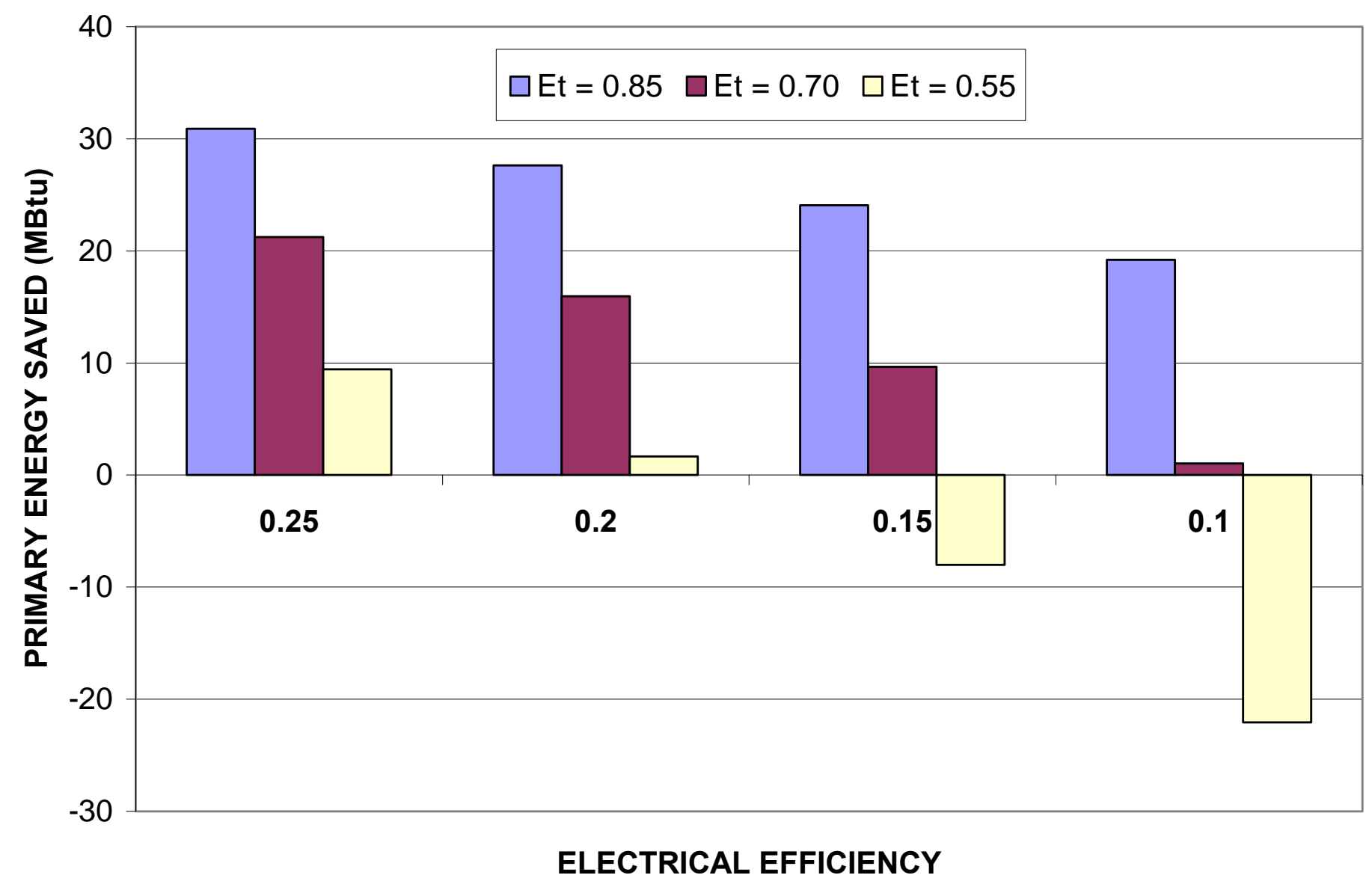

Figure 4-6. Primary energy savings by total efficiency for 2-kW (electric) systems on Long Island NO REVERSE METERING 
TOTAL EFFICIENCY (Et) COMPARISON LONG ISLAND

3 kW MCHP NO REVERSE METERING

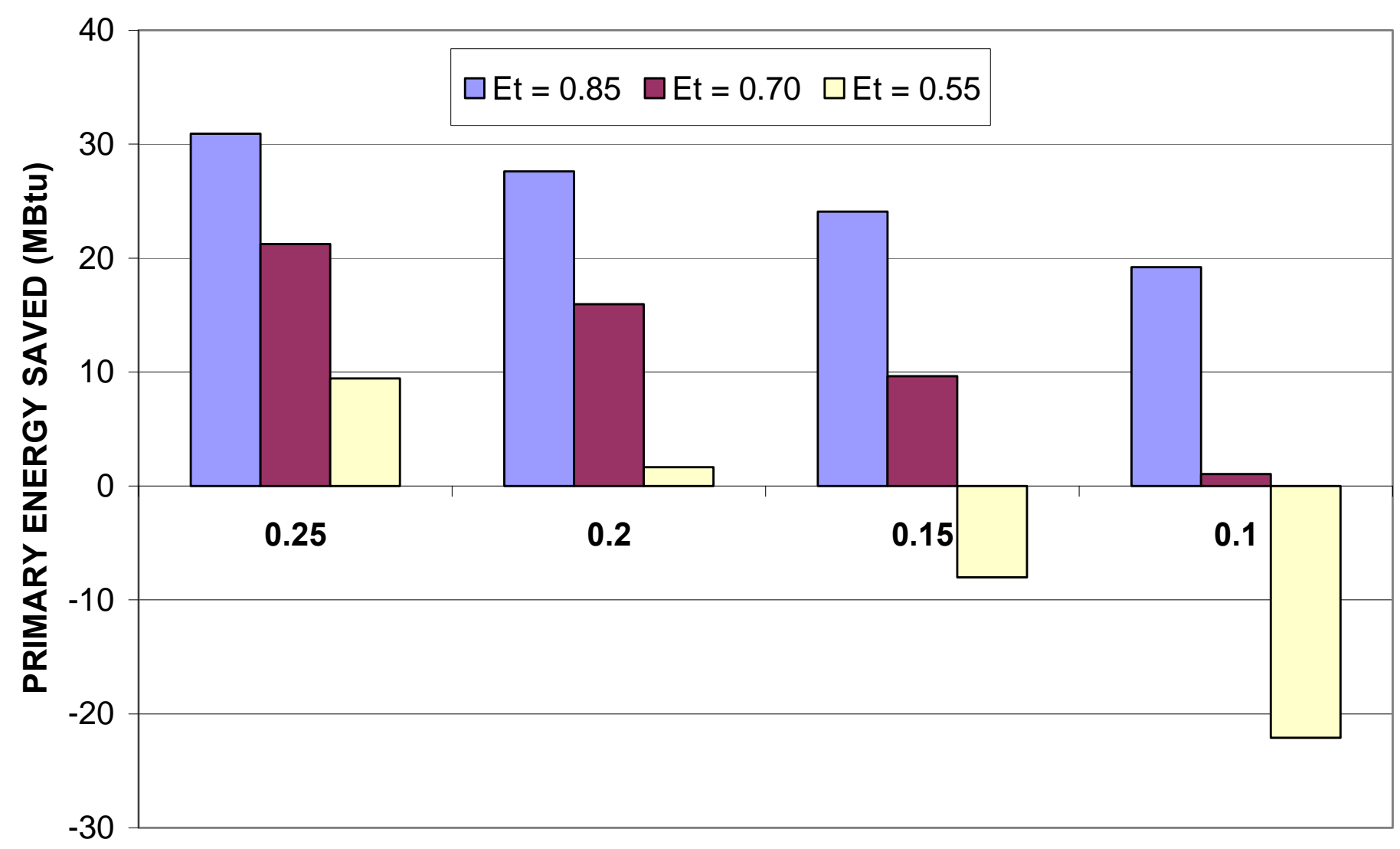

\section{ELECTRICAL EFFICIENCY}

Figure 4-7. Primary energy savings by total efficiency for 3-kW (electric) systems on Long Island NO REVERSE METERING 
TOTAL EFFICIENCY (Et) COMPARISON LONG ISLAND

$0.5 \mathrm{~kW}$ MCHP NO REVERSE METERING

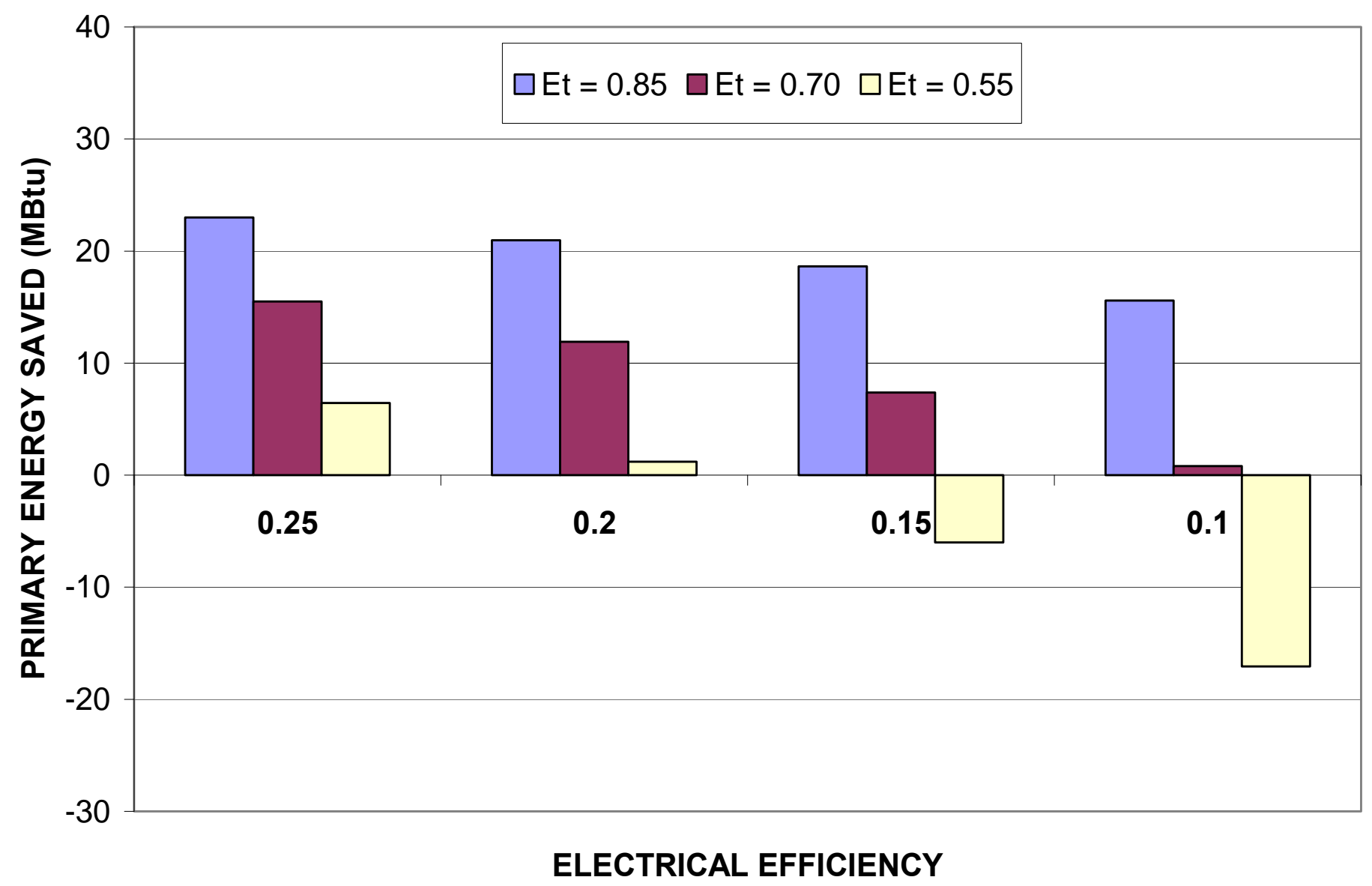

Figure 4-8. Primary energy savings by total efficiency for $0.5-\mathrm{kW}$ (electric) systems on Long Island NO REVERSE METERING 


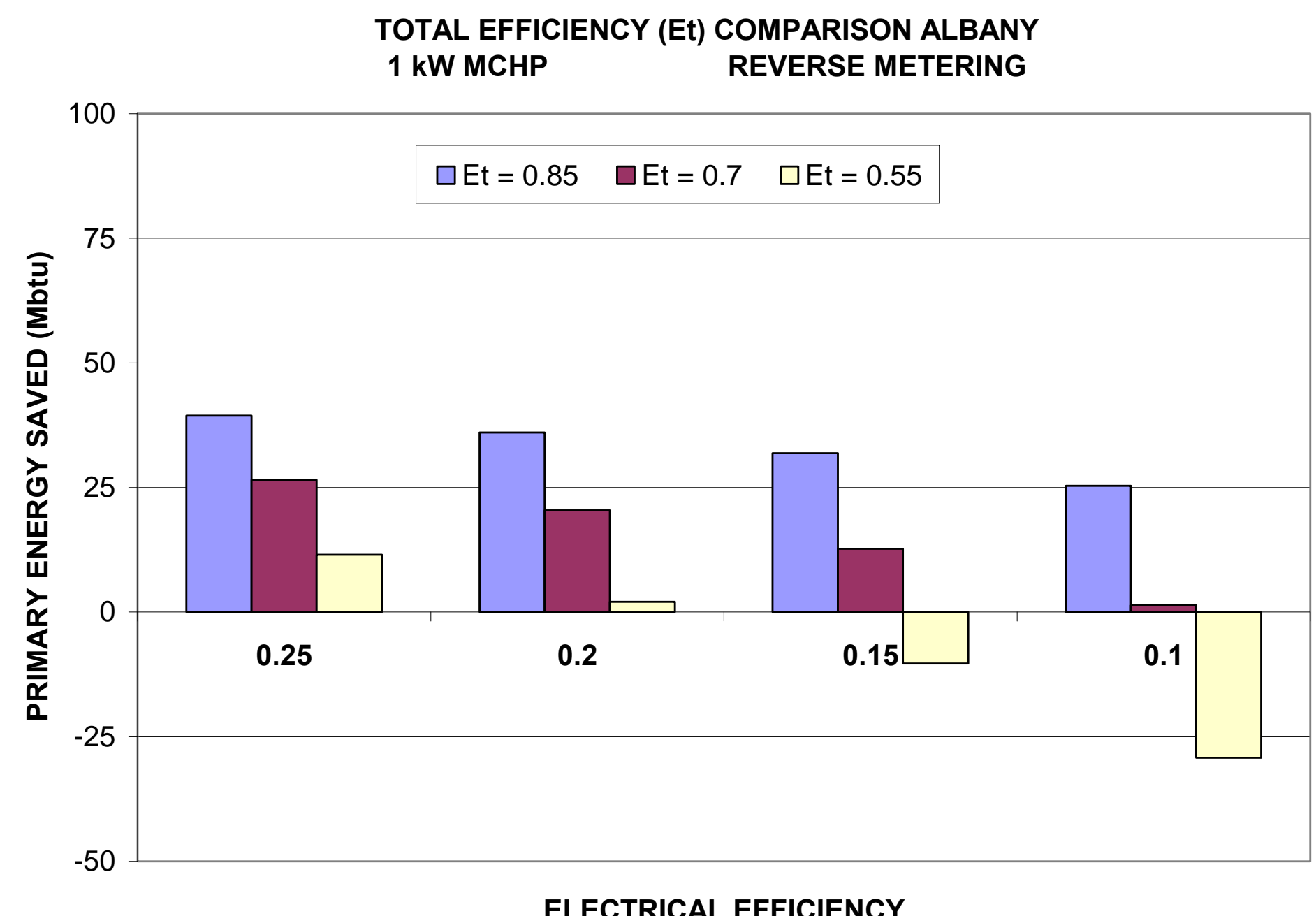

Figure 4-9. Primary energy savings by total efficiency for 1-kW (electric) systems in Albany REVERSE METERING 


\section{TOTAL EFFICIENCY (Et) COMPARISON ALBANY}

3kW MCHP REVERSE METERING

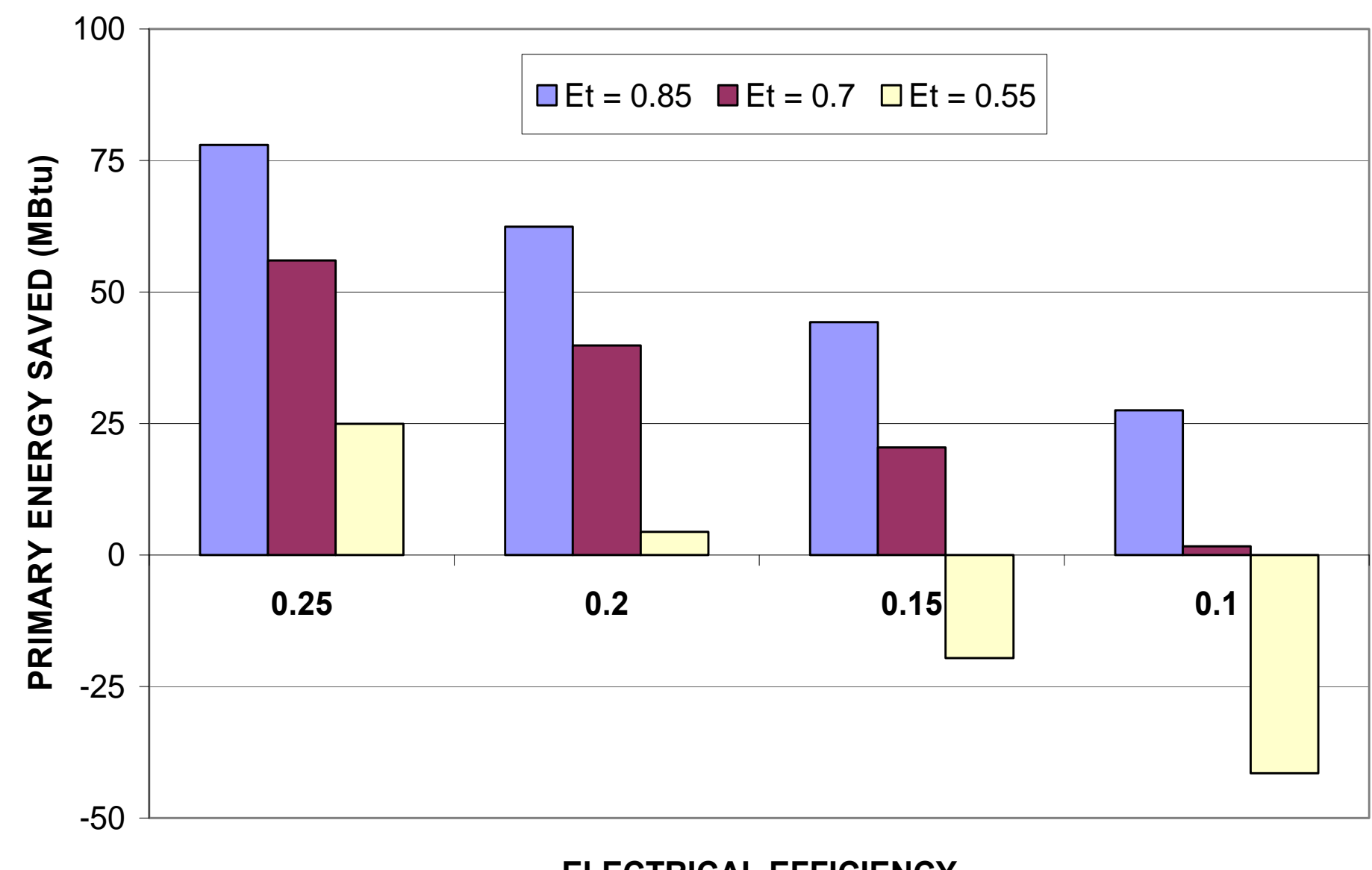

ELECTRICAL EFFICIENCY

Figure 4-10. Primary energy savings by total efficiency for 3-kW (electric) systems in Albany REVERSE METERING 


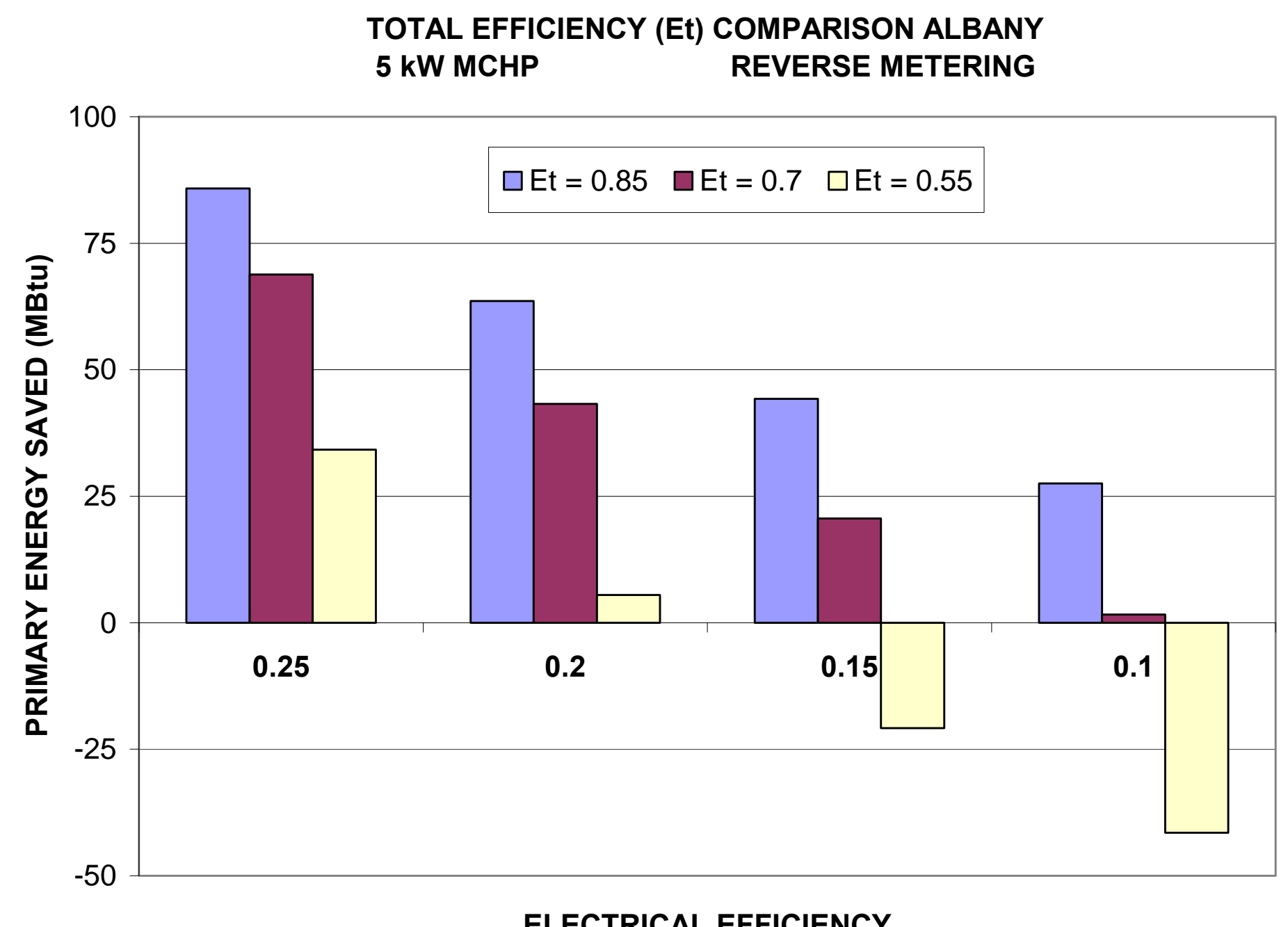

Figure 4-11. Primary energy savings by total efficiency for 5-kW (electric) systems in Albany REVERSE METERING 
TOTAL EFFICIENCY (Et) COMPARISON LONG ISLAND

$1 \mathrm{~kW}$ MCHP REVERSE METERING

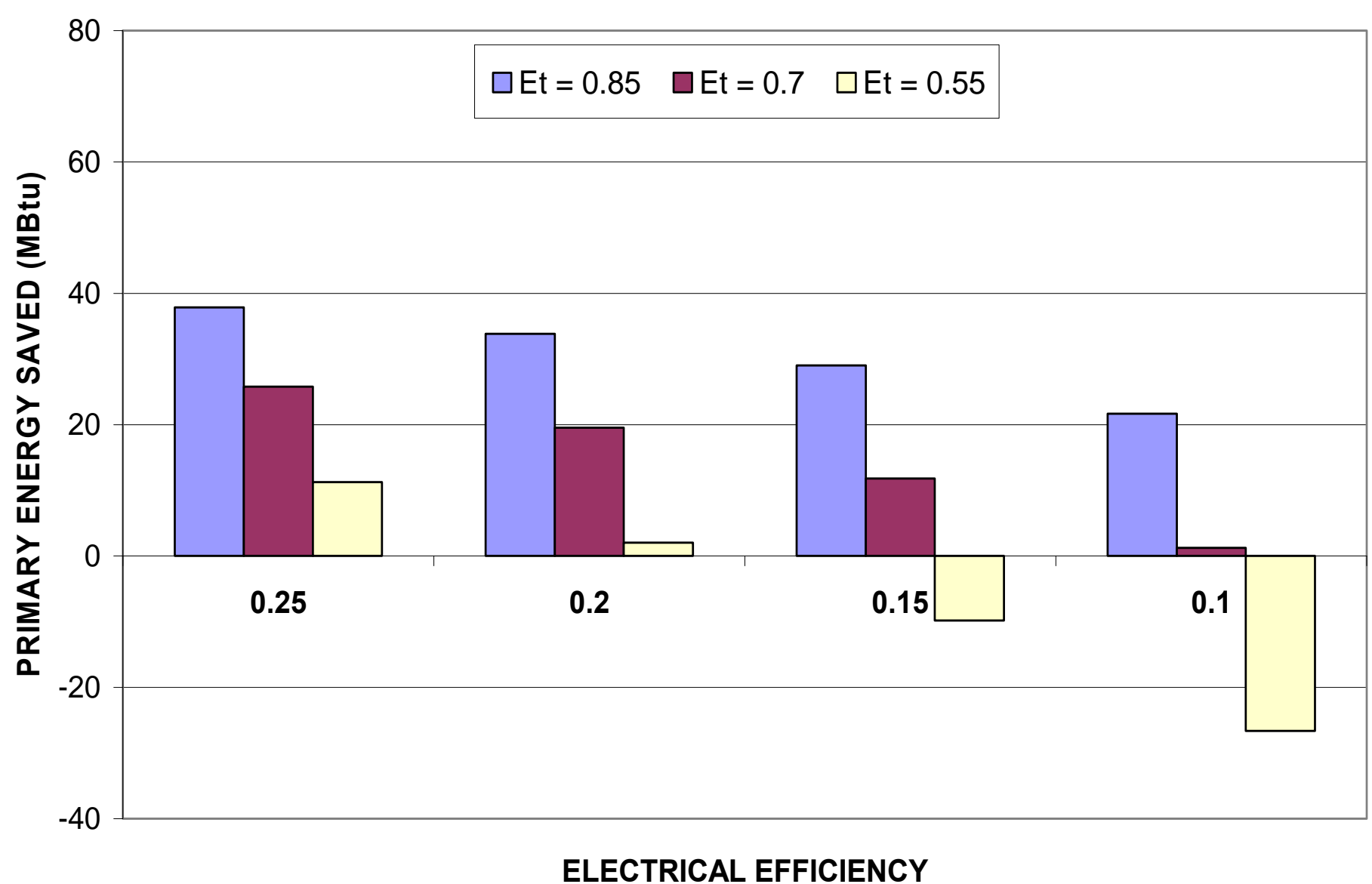

Figure 4-12. Primary energy savings by total efficiency for 1-kW (electric) systems on Long Island REVERSE METERING 
TOTAL EFFICIENCY (Et) COMPARISON LONG ISLAND

$3 \mathrm{~kW}$ MCHP REVERSE METERING

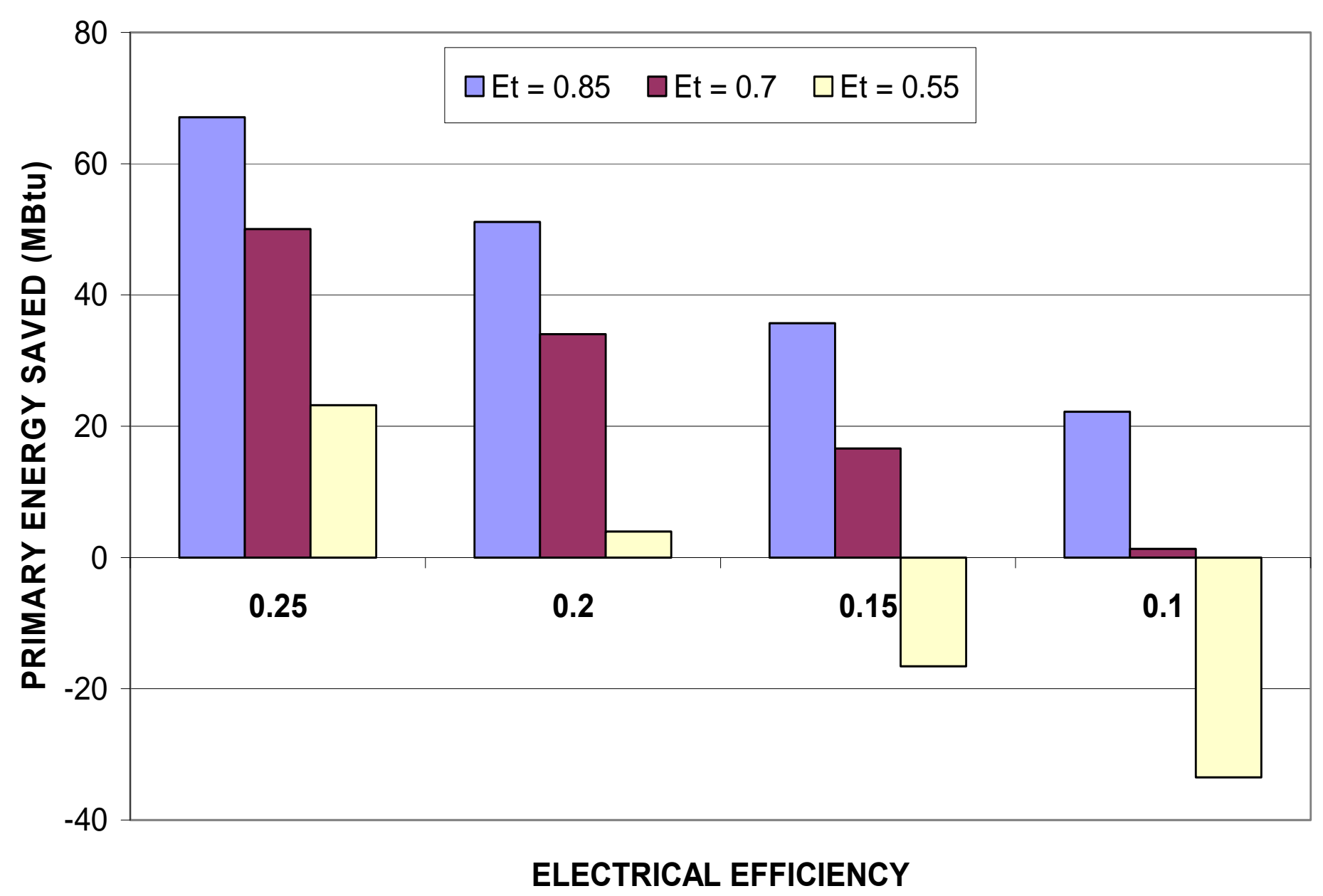

Figure 4-13. Primary energy savings by total efficiency for 3-kW (electric) systems on Long Island REVERSE METERING 
TOTAL EFFICIENCY (Et) COMPARISON LONG ISLAND 5 kW MCHP REVERSE METERING

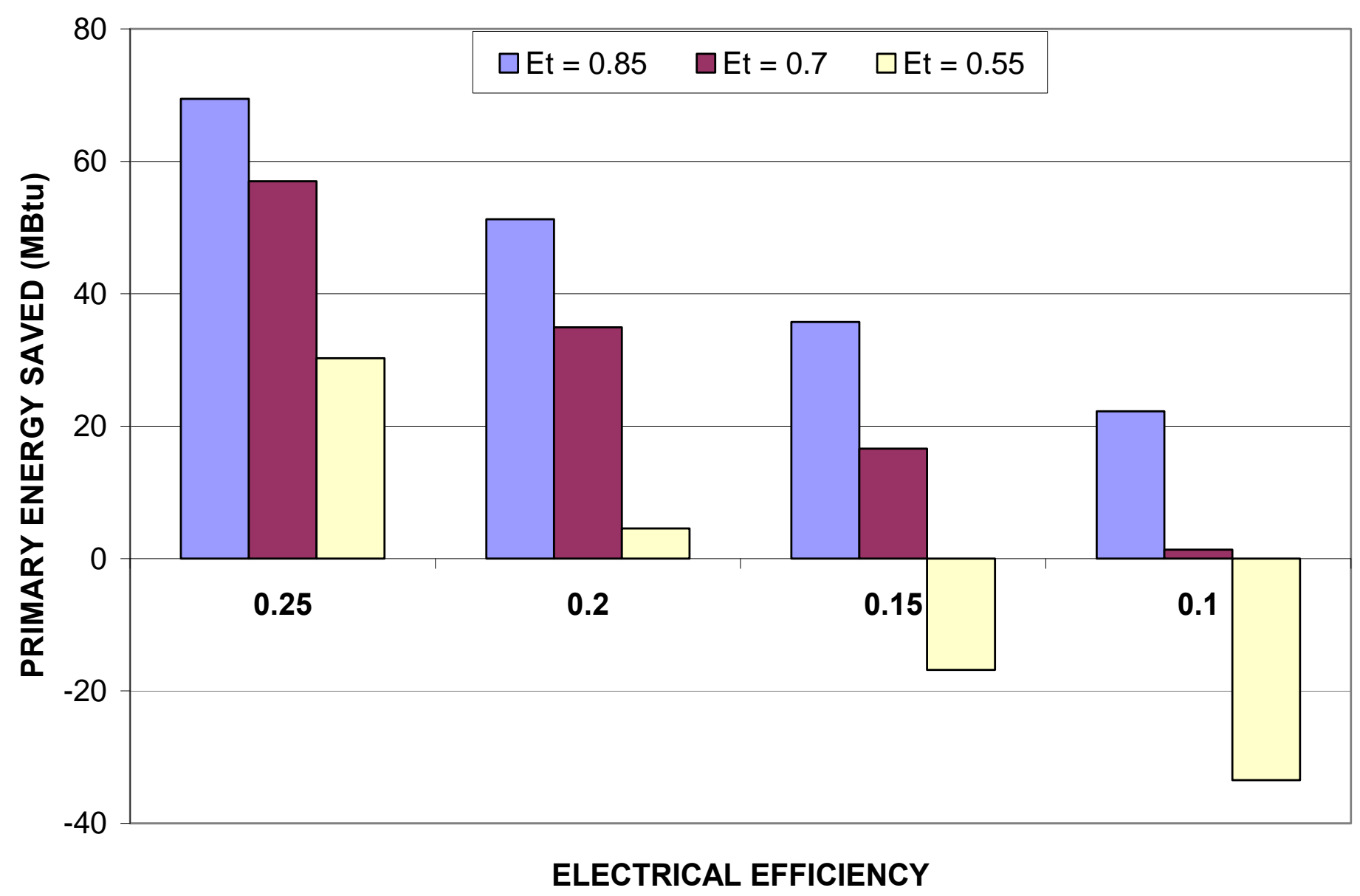

Figure 4-14. Primary energy savings by total efficiency for 5-kW (electric) systems on Long Island REVERSE METERING 


\section{HYBRID CAR RECHARGING IMPACTS ON ENERGY SAVINGS AND REVERSE METERING}

\section{Analysis Description}

This section builds on the previous analysis by investigating the effect of a nighttime electric load imposed by the need to recharge a hybrid electric automobile. The following three questions were asked:

1. In a system with reverse metering, to what extent will the ability to divert excess power to the automobile recharge task reduce the amount of electric energy that must be returned to the grid?

2. What percentage of the incremental primary energy savings obtained by reverse metering can be captured in a non-reverse-metered system with the presence of the additional electric power load represented by the need to recharge the vehicle?

3. What impact will the presence of the vehicle recharge load affect the primary energy savings in a system with reverse metering?

Please note that this section discusses both reverse-metered systems and systems that do not return power to the grid. It is important at each stage to be clear on which type of system is being considered at the moment. Otherwise confusion will reign. The author hopes that he as done an adequate job of pointing the reader in the right direction throughout.

In the previous analyses, certain simplifying assumptions were made. These included:

- Constant electric and thermal efficiencies for all means of production of heat and electricity, regardless of turndown or fractional ontime.

- No electrical storage.

- Thermal storage is limited to domestic hot water (DHW) tank. Storage losses were taken as constant and included in the DHW load.

The same assumptions hold in the present analysis, with the one difference that now the batteries of a hybrid (or all-electric) vehicle are in need of recharging at night. This constitutes an element of electric-power storage, albeit one that is available only at certain times of the day.

\section{Vehicle Battery Recharge Assumptions}

In this baseline analysis, it was assumed that the recharge of the vehicle battery will impose a constant electric-power load over a specific time period during the evening and nighttime hours. It is also assumed that this load will occur every day of the year. Although neither of these assumptions is likely to hold exactly in any practical application, it is hoped that they might provide a baseline from which further thinking can proceed.

The actual recharge load will depend on several factors, including the length of the recharge period, the design of the vehicle, and the number of miles it is desired to drive before either recharge of the batteries or reversion to the onboard internal-combustion engine is required. The 
latter two considerations will dictate the capacity of the battery in kilowatt-hours $(\mathrm{kWh})$. Dividing this capacity by the number of hours devoted to recharge will provide the recharge load in kilowatts $(\mathrm{kW})$.

A report by the American Council for an Energy-Efficient Economy (Klisech and Langer 2006) provides information on expected hybrid-car battery capacities. Conventional hybrids (not plugins) have capacities ranging from 1 to $2 \mathrm{kWh}$. If a 20-mile range is desired, the battery capacity would need to be between 6 and $8 \mathrm{kWh}$. At the high end of the range of possibilities, a 60 -mile range would require a capacity ranging from 18 to $21 \mathrm{kWh}$. Reference is also made to another report (Anderman 2006) which gave somewhat higher numbers: $10-15 \mathrm{kWh}$ for a 20-mile range and $25-30 \mathrm{kWh}$ for a 60 -mile range.

In view of these estimates, it was decided to parameterize the battery capacity between $10 \mathrm{kWh}$ and $25 \mathrm{kWh}$, in $5-\mathrm{kWh}$ increments. The time frame for recharging was taken as the ten-hour period beginning at 8 p.m. and ending at 6 a.m.

\section{Impact on Reverse Metering}

A major motivation for studying the connection between a micro-CHP system and the need to recharge a hybrid car is the perceived reluctance of many electric utilities to allow reverse metering with micro-CHP systems, because of the negative impact on their load factors. The micro-CHP systems provide energy to the grid in the winter, when it isn't needed by summerpeaking utilities, but not in the summer, when it is. This contrasts with photovoltaic systems, which provide most of their electric power in the summer. The thought here is that the hybrid vehicle's battery could provide an alternative sink for electric energy, reducing the amount of energy that the utility would have to accept in a reverse-metered system.

Figures 5-1 through 5-8 show the magnitudes of the impacts predicted by the analysis. The eight figures represent two locations (Albany and Long Island), two micro-CHP power outputs ( $3 \mathrm{~kW}$ and $5 \mathrm{~kW})$ and two electric efficiencies $(25 \%$ and $20 \%)$. These were seen as the cases of greatest interest because they are the cases where there is the most reverse metering. Systems with less power output and/or less electric efficiency return much less power to the grid. This was discussed in Sections I and II of this report.

Each figure provides values by month and by battery capacity, with zero capacity, i.e., no hybrid recharge, included for comparison.

The analysis predicts that for a $25 \mathrm{kWh}$ battery, the amount of electric energy that is reversemetered during the five coldest months of the year (November through March) will be about half of what it is with no vehicle battery recharging. Lower battery capacities provide lesser reductions.

Tables 5-1 and 5-2 provide the numbers resulting from the analysis. For each of the eight systems studied (two locations, two electric efficiencies, and two micro-CHP capacities), the number of kilowatt-hours of electric energy reverse-metered during the cold months is shown. In each case, the adjoining column shows this as a percent of the amount reverse-metered when 
there is no hybrid-car recharge. The bold figures show these percentages for the largest car battery studied.

Table 5-1. Electric Energy Reverse-Metered in Albany, November through March

\begin{tabular}{lccccccrr} 
Car & \multicolumn{3}{c}{$25 \%$ Electric Efficiency } & \multicolumn{3}{c}{$20 \%$ Electric Efficiency } \\
Battery & \multicolumn{2}{c}{$3 \mathrm{~kW}$} & \multicolumn{2}{c}{$5 \mathrm{~kW}$} & \multicolumn{2}{c}{$3 \mathrm{~kW}$} & \multicolumn{3}{c}{$5 \mathrm{~kW}$} \\
$\quad \mathrm{VWh}$ & $\%$ & $\mathrm{kWh}$ & $\%$ & $\mathrm{kWh}$ & $\%$ & $\mathrm{kWh}$ & $\%$ \\
None & 6583 & 100 & 7839 & 100 & 5007 & 100 & 6840 & 100 \\
$10 \mathrm{kWh}$ & 5118 & 77.7 & 6373 & 81.3 & 3606 & 72.0 & 5263 & 76.9 \\
$15 \mathrm{kWh}$ & 4432 & 67.3 & 5689 & 72.6 & 3031 & 60.5 & 4544 & 66.4 \\
$20 \mathrm{kWh}$ & 3851 & 58.5 & 5076 & 64.8 & 2610 & 52.1 & 3940 & 57.6 \\
$25 \mathrm{kWh}$ & 3451 & $\mathbf{5 2 . 4}$ & 4560 & $\mathbf{5 8 . 2}$ & 2375 & $\mathbf{4 7 . 4}$ & 3525 & $\mathbf{5 1 . 5}$
\end{tabular}

Table 5-2. Electric Energy Reverse-Metered on Long Island, November through March

\begin{tabular}{lcccccccr} 
Car & \multicolumn{3}{c}{$25 \%$ Electric Efficiency } & \multicolumn{3}{c}{$20 \%$ Electric Efficiency } \\
Battery & \multicolumn{2}{c}{$3 \mathrm{~kW}$} & \multicolumn{2}{c}{$5 \mathrm{~kW}$} & \multicolumn{3}{c}{$3 \mathrm{~kW}$} & \multicolumn{3}{c}{$5 \mathrm{~kW}$} \\
$\quad$ V & $\mathrm{kWh}$ & $\%$ & $\mathrm{kWh}$ & $\%$ & $\mathrm{kWh}$ & $\%$ & $\mathrm{kWh}$ & $\%$ \\
None & 5551 & 100 & 5936 & 100 & 3811 & 100 & 3837 & 100 \\
$10 \mathrm{kWh}$ & 4157 & 74.9 & 4542 & 76.5 & 2506 & 65.8 & 2532 & 66.0 \\
$15 \mathrm{kWh}$ & 3525 & 63.5 & 3910 & 65.9 & 2012 & 52.8 & 2038 & 53.1 \\
$20 \mathrm{kWh}$ & 2998 & 54.0 & 3366 & 56.7 & 1705 & 44.7 & 1728 & 45.0 \\
$25 \mathrm{kWh}$ & 2653 & $\mathbf{4 7 . 8}$ & 2956 & $\mathbf{4 9 . 8}$ & 1568 & $\mathbf{4 1 . 1}$ & 1582 & $\mathbf{4 1 . 2}$
\end{tabular}

These may be considered significant reductions, but they do not eliminate the issue of utility impact of reverse metering. One suggestion for further reducing this is to provide a stationary battery alongside the micro-CHP system for additional electric energy storage when the car is away from home. Such storage would presumably be less costly than that which has to ride in a vehicle. The cost would still be significant, however, and there are questions of power management, transaction losses in passing energy from one battery to another, and system complexity issues. These questions are all beyond the scope of this report.

Now let us consider the impact of vehicle battery recharging on primary energy savings. We will treat separately the cases where there is and is not reverse metering.

\section{Impact on Primary Energy Savings - No Reverse Metering}

In the previous section, we considered a system that was reverse-metered and asked about the impact vehicle recharging would have on the amount of electric energy returned to the grid. Here, in contrast, we are considering a system without reverse metering and asking what the battery charging task will do to the energy savings.

Without reverse metering, the primary energy savings increases when the electric vehicle battery recharging task is added to the micro-CHP system. The reason for this is that the micro-CHP system can operate more hours, namely when there is enough thermal load to support the house electric load plus the generation of additional electric energy required by the vehicle battery. 
Figure 5-9 shows the impact on energy savings in Albany for micro-CHP systems with an electric efficiency of $25 \%$ and electric output capacities ranging from $1 \mathrm{~kW}$ to $5 \mathrm{~kW}$.

It is critical to understand what each of the different lines represents. Most important, all of the lines except the top one represent systems without reverse metering. The bottom line represents systems with no electric vehicle recharging. The next four lines in ascending order represent the energy savings with electric vehicle battery capacities ranging from $10 \mathrm{~kW}$ to $25 \mathrm{~kW}$. Finally, the top line represents a "target," namely the amount of primary energy that can be saved if reverse metering is allowed. By observing the placement of the intermediate lines with respect to the top and bottom lines, one can assess the degree to which the presence of the battery recharge load could substitute for reverse metering, in terms of garnering primary energy savings.

The figure shows that for micro-CHP electric outputs in the $3 \mathrm{~kW}$ to $5 \mathrm{~kW}$ range, a $25 \mathrm{kWh}$ car battery's load can provide about half of the incremental energy savings that reverse metering can.

Figure 5-10 shows similar results for 20\% electric efficiency systems in Albany. Here the largest hybrid car battery allows the system to obtain about two-thirds of the incremental energy savings that reverse-metering can. This is largely a result of the fact that reverse metering doesn't provide as much energy savings here as it does in the $25 \%$ electric efficiency case. The added savings from the hybrid battery recharge is actually less than it is in the previous case, but it is a larger percentage of the increment provided by reverse metering.

Figures 5-11 and 5-12 show similar results for Long Island. The added energy savings from hybrid car battery recharge is smaller in absolute terms than it is in Albany, but it is a larger percentage of the incremental savings provided by reverse metering.

Tables 5-3 and 5-4 show the numbers for Albany and Long Island, for the electric outputs of 3 $\mathrm{kW}$ and $5 \mathrm{~kW}$, and electric efficiencies of $25 \%$ and $20 \%$. Although these tables look a lot like Tables 1 and 2, it is important to remember that they are displaying completely different things. The two earlier tables dealt with reverse-metered electric energy, while these show primaryenergy savings. Moreover, although the systems studied in the previous section had reverse metering, the systems studied here do not. (The first line in Tables 5-3 and 5-4 is shown for comparison purposes, and has nothing else to do with the systems under consideration here.)

The additional energy savings available from having a $25 \mathrm{kWh}$ battery to recharge each night, as a percentage of the incremental savings available from reverse metering (without battery recharge) are shown in bold type. 
Table 5-3. Primary Energy Savings in Albany Compared with No Recharge and Reverse Metering

\begin{tabular}{|c|c|c|c|c|c|c|c|c|}
\hline & \multicolumn{4}{|c|}{ 25\% Electric Efficiency } & \multicolumn{4}{|c|}{ 20\% Electric Efficiency } \\
\hline & \multicolumn{2}{|c|}{$3 \mathrm{~kW}$} & \multicolumn{2}{|c|}{$5 \mathrm{~kW}$} & \multicolumn{2}{|c|}{$3 \mathrm{~kW}$} & \multicolumn{2}{|c|}{$5 \mathrm{~kW}$} \\
\hline & Mbtu & $\%$ of incr. & Mbtu & $\%$ of incr. & Mbtu & $\%$ of incr. & Mbtu & $\%$ of incr. \\
\hline Reverse Metering (RM) & 77.94 & 100 & 85.85 & 100 & 62.42 & 100 & 63.56 & 100 \\
\hline 25 kWh (No RM) & 57.27 & 55.1 & 59.06 & 50.3 & 50.50 & 64.4 & 51.59 & 65.4 \\
\hline 20 kWh (No RM) & 54.18 & 48.4 & 54.54 & 42.0 & 48.33 & 57.9 & 48.61 & 56.8 \\
\hline 15 kWh (No RM) & 49.48 & 38.2 & 49.48 & 32.6 & 44.70 & 47.0 & 44.7 & 45.5 \\
\hline 10 kWh (No RM) & 43.97 & 26.2 & 43.97 & 22.4 & 40.13 & 33.4 & 40.13 & 32.3 \\
\hline No Recharge, No RM & 31.91 & 0 & 31.91 & 0 & 28.97 & 0 & 28.97 & 0 \\
\hline
\end{tabular}

Note: $\%$ of incr. means percent of the incremental energy savings provided by reverse metering.

Table 5-4. Primary Energy Savings on Long Island Compared with No Recharge and Reverse Metering

\begin{tabular}{|c|c|c|c|c|c|c|c|c|}
\hline & \multicolumn{4}{|c|}{ 25\% Electric Efficiency } & \multicolumn{4}{|c|}{ 20\% Electric Efficiency } \\
\hline & \multicolumn{2}{|c|}{$3 \mathrm{~kW}$} & \multicolumn{2}{|c|}{$5 \mathrm{~kW}$} & \multicolumn{2}{|r|}{$3 \mathrm{~kW}$} & \multicolumn{2}{|c|}{$5 \mathrm{~kW}$} \\
\hline & Mbtu & $\%$ of incr. & Mbtu & $\%$ of incr. & Mbtu & $\%$ of incr. & Mbtu & $\%$ of incr. \\
\hline Reverse Metering (RM) & 67.09 & 100 & 69.44 & 100 & 51.12 & 100 & 51.28 & 100 \\
\hline 25 kWh (No RM) & 52.72 & 60.3 & 54.17 & 60.4 & 44.99 & 73.9 & 45.67 & 76.3 \\
\hline 20 kWh (No RM) & 50.16 & 53.2 & 50.47 & 50.8 & 43.54 & 67.7 & 43.73 & 68.1 \\
\hline 15 kWh (No RM) & 46.37 & 42.7 & 46.37 & 40.1 & 40.85 & 56.3 & 40.85 & 55.9 \\
\hline 10 kWh (No RM) & 41.74 & 29.9 & 41.74 & 28.1 & 37.10 & 40.3 & 37.10 & 40.1 \\
\hline No Recharge, No RM & 30.91 & 0 & 30.91 & 0 & 27.62 & 0 & 27.62 & 0 \\
\hline
\end{tabular}

Note: \% of incr. means percent of the incremental energy savings provided by reverse metering.

\section{Primary Energy Savings with both Reverse Metering and Electric Vehicle Recharge}

The final question to be answered in this analysis is: What happens to the primary energy savings if one is fortunate enough to have both reverse metering and a vehicle battery to recharge? The answer is very simple, which will make this section very short. Once you have reverse metering, adding the vehicle battery load does not affect primary energy savings at all!

To see why this should be the case, consider that whether or not there is a vehicle recharge load, the availability of reverse metering allows the micro-CHP system to run as many hours as the thermal load will support. Adding the battery recharge load does not change this. At the level of detail supported by this analysis, it doesn't matter whether electric energy in excess of the house's needs goes to the grid or to a car battery.

In a more realistic case, it might matter. For example, sending power directly to a car battery will reduce transmission and distribution losses associated with sending the power into the grid. Such considerations are, however, beyond the scope of the present analysis. To a first approximation, the primary energy savings are unaffected by the presence of the battery recharge load, once reverse metering is allowed. This contrasts sharply with the case where reverse metering is not allowed, where the battery recharge load makes a big difference. 


\section{$\underline{\text { Conclusions }}$}

The following conclusions were reached as a result of the analyses reported on here.

- In a reverse-metered micro-CHP system, the presence of a nighttime vehicle battery recharge load of $10 \mathrm{kWh}$ to $25 \mathrm{kWh}$ significantly reduces the amount of electric power sent back to the grid. For the $25 \mathrm{kWh}$ battery, the amount of electric energy reverse metered during the November - March period was $40 \%$ to $60 \%$ of what it would be without the battery recharge load.

- In a micro-CHP system without reverse metering, the presence of a nighttime vehicle battery recharge load of $10 \mathrm{kWh}$ to $25 \mathrm{kWh}$ significantly raises the primary energy savings for the micro-CHP system. The load represented by the $25 \mathrm{kWh}$ battery results in an increase in energy savings (over that with no battery) of from one-half to three-fourths of the increase that reverse metering would provide.

- In a reverse-metered micro-CHP system, adding the vehicle battery recharge load does not change the primary energy savings for the system.

\section{Section IV References}

Anderman, M. 2006. "Batteries for HEV—2006 to 2010: NiMH Expansion, Li Ion Introduction." Proceedings of the 2006 Advanced Automotive Battery and Ultracapacitor Conforence. Oregon House, Calif.: Advanced Automotive Batteries. (Reference provided in Klisech and Langer 2006)

Klisech, J. and T. Langer 2006. "Plug-In Hybrids: An Environmental and Economic Performance Outlook." American Council for an Energy-Efficient Economy, Report No. T061, Washington, DC. 
HYBRID CAR RECHARGE WITH REVERSE METERING

3 kW SYSTEM IN ALBANY, 25\% ELECTRIC EFFICIENCY

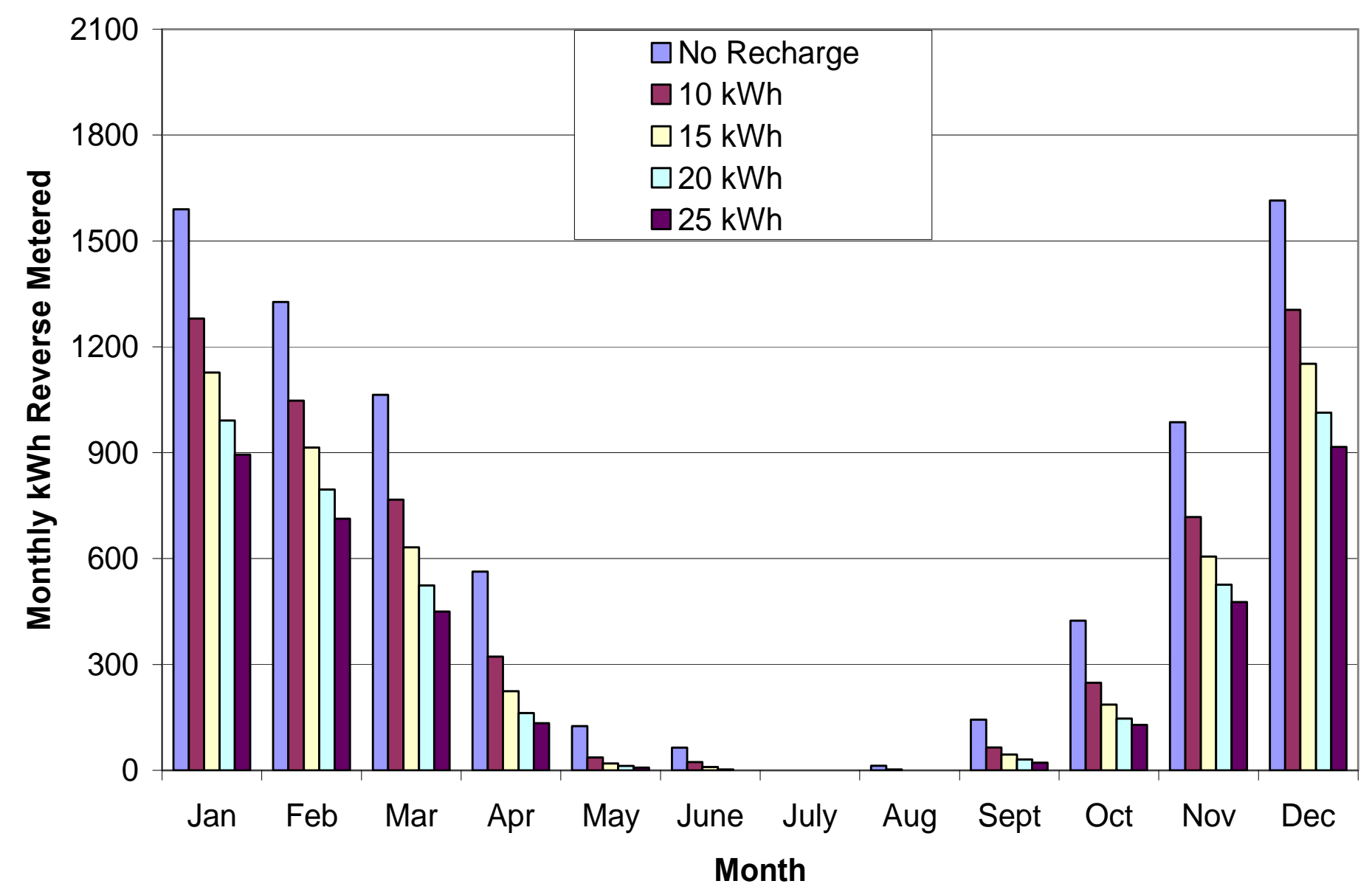

Figure 5-1. Monthly Reverse Metering for Various Car Battery Capacities, 3 kW System in Albany (25\% Electric Efficiency) 
HYBRID CAR RECHARGE WITH REVERSE METERING

5 kW SYSTEM IN ALBANY, 25\% ELECTRIC EFFICIENCY

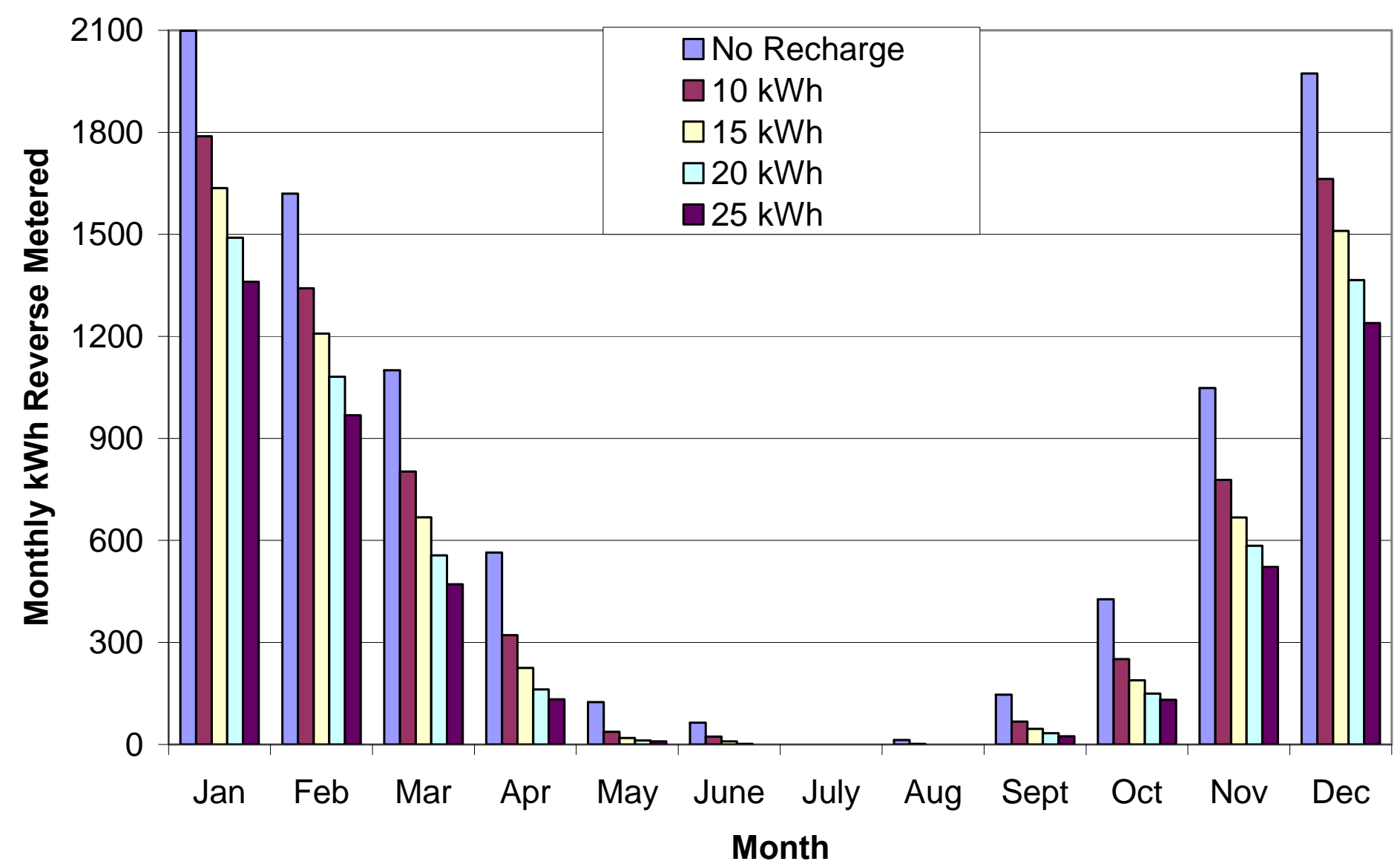


Figure 5-2. Monthly Reverse Metering for Various Car Battery Capacities, 5 kW System in Albany (25\% Electric Efficiency)

HYBRID CAR RECHARGE WITH REVERSE METERING 3 kW SYSTEM IN ALBANY, 20\% ELECTRIC EFFICIENCY

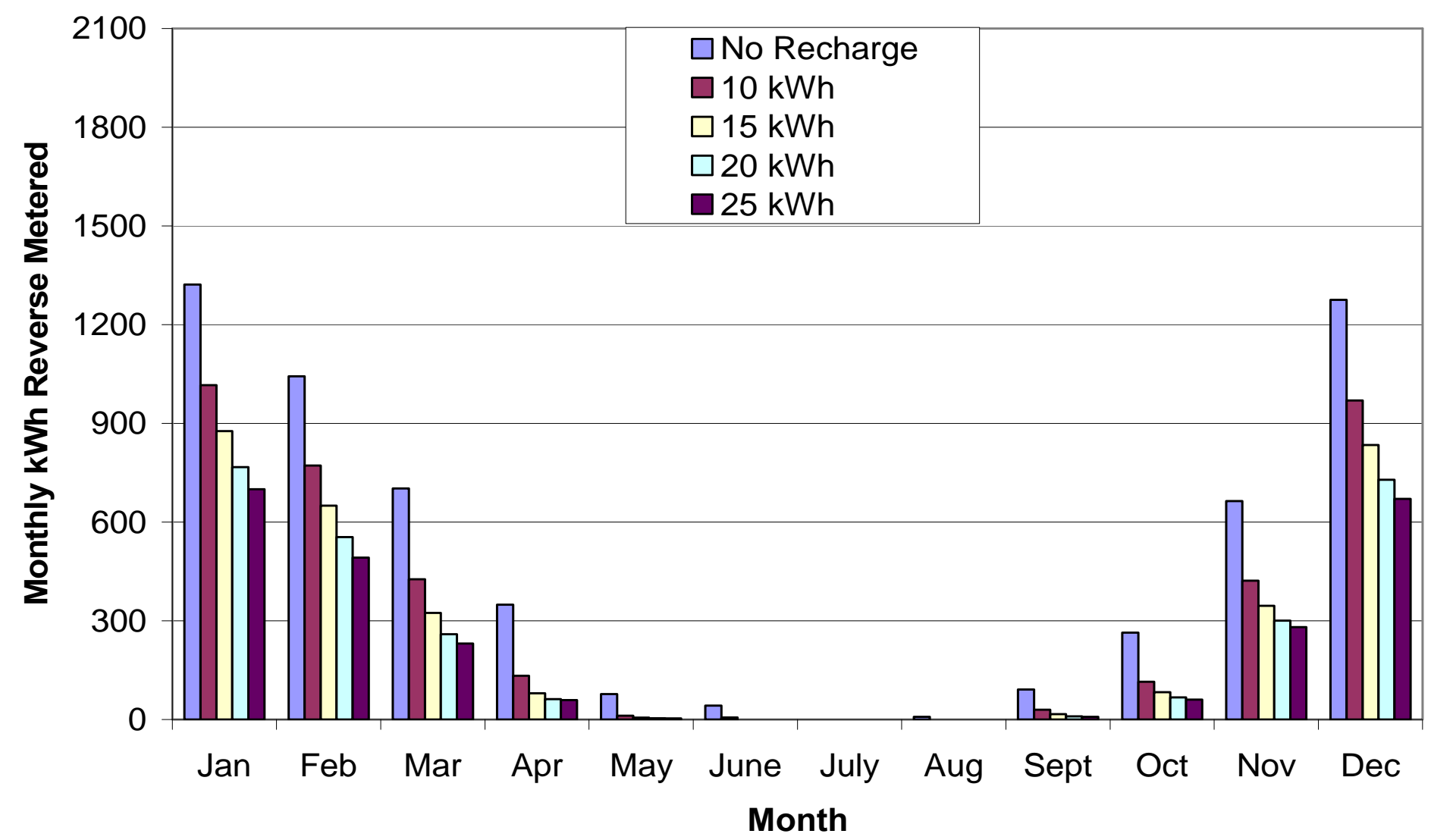


Figure 5-3. Monthly Reverse Metering for Various Hybrid Battery Capacities, 3 kW System in Albany (20\% Electric Efficiency) 
HYBRID CAR RECHARGE WITH REVERSE METERING

5 kW SYSTEM IN ALBANY, 20\% ELECTRIC EFFICIENCY

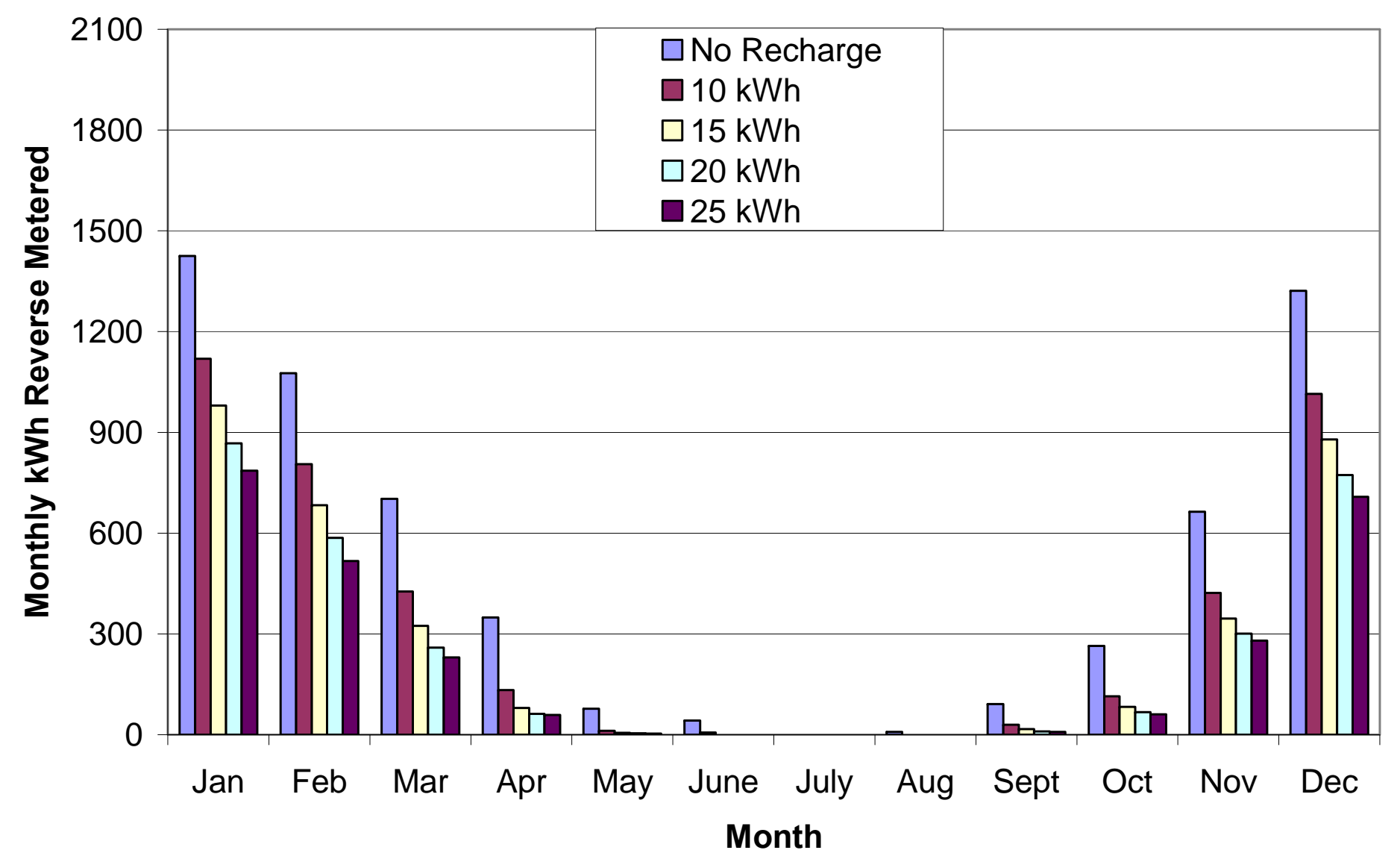

Figure 5-4. Monthly Reverse Metering for Various Car Battery Capacities, 5 kW System in Albany (20\% Electric Efficiency) 
HYBRID CAR RECHARGE WITH REVERSE METERING 3kW SYSTEM ON LONG ISLAND, 25\% ELECTRIC EFFICIENCY

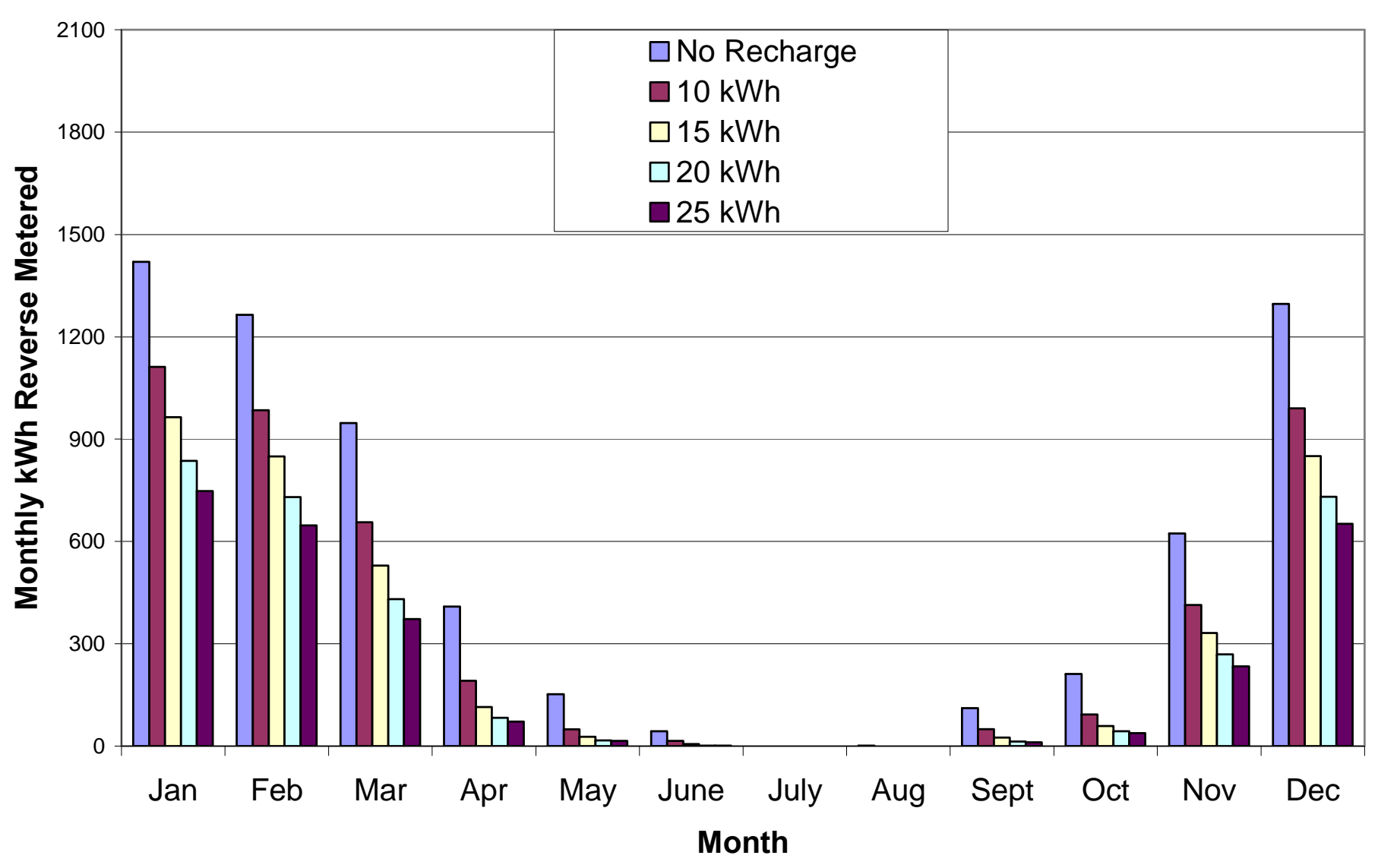

Figure 5-5. Monthly Reverse Metering for Various Car Battery Capacities, $3 \mathrm{~kW}$ System on Long Island (25\% Electric Efficiency) 
HYBRID CAR RECHARGE WITH REVERSE METERING 5kW SYSTEM ON LONG ISLAND, 25\% ELECTRIC EFFICIENCY

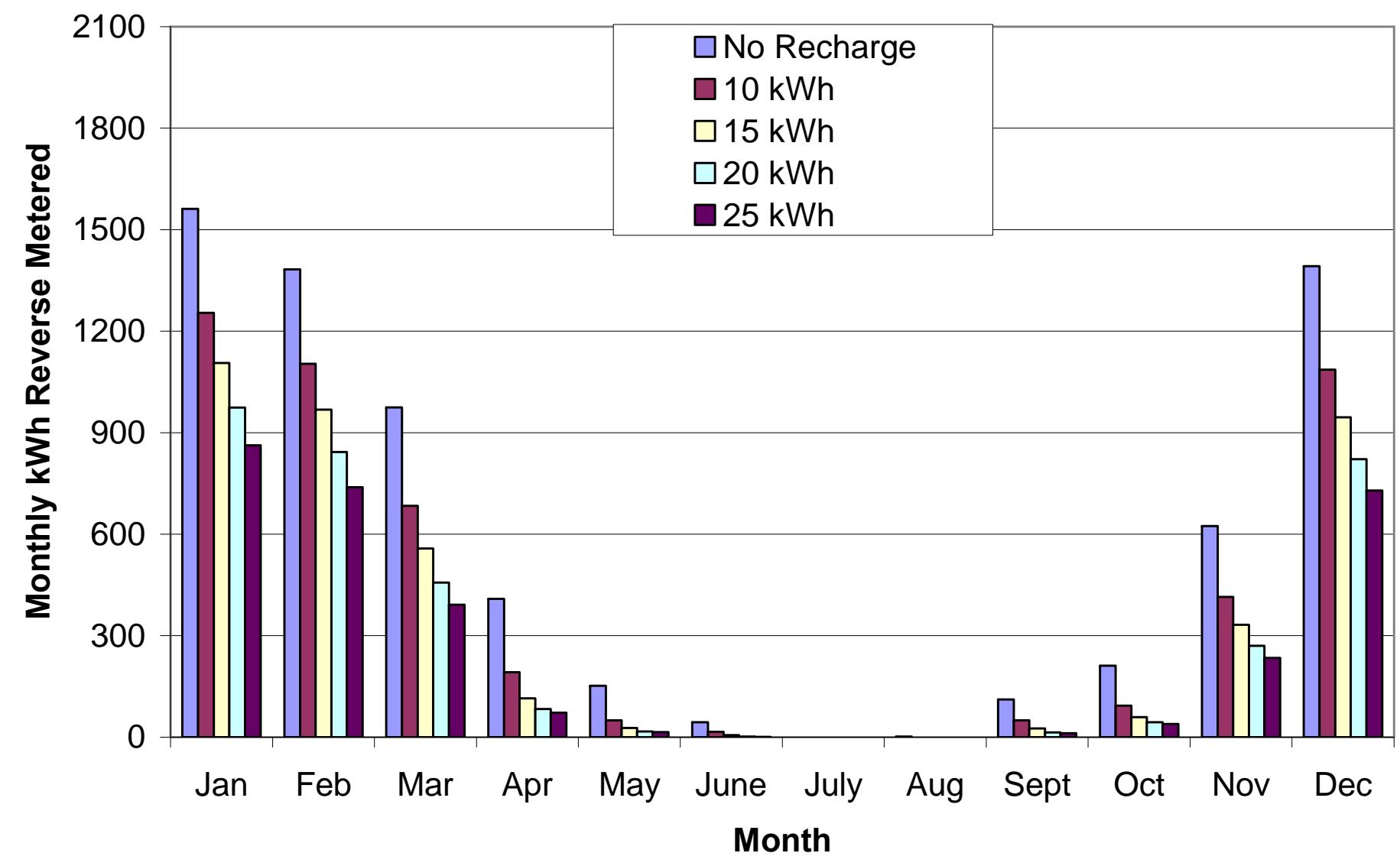

Figure 5-6. Monthly Reverse Metering for Various Car Battery Capacities, 5 kW System on Long Island (25\% Electric Efficiency) 
HYBRID CAR RECHARGE WITH REVERSE METERING $3 \mathrm{~kW}$ SYSTEM ON LONG ISLAND, 20\% ELECTRIC EFFICIENCY

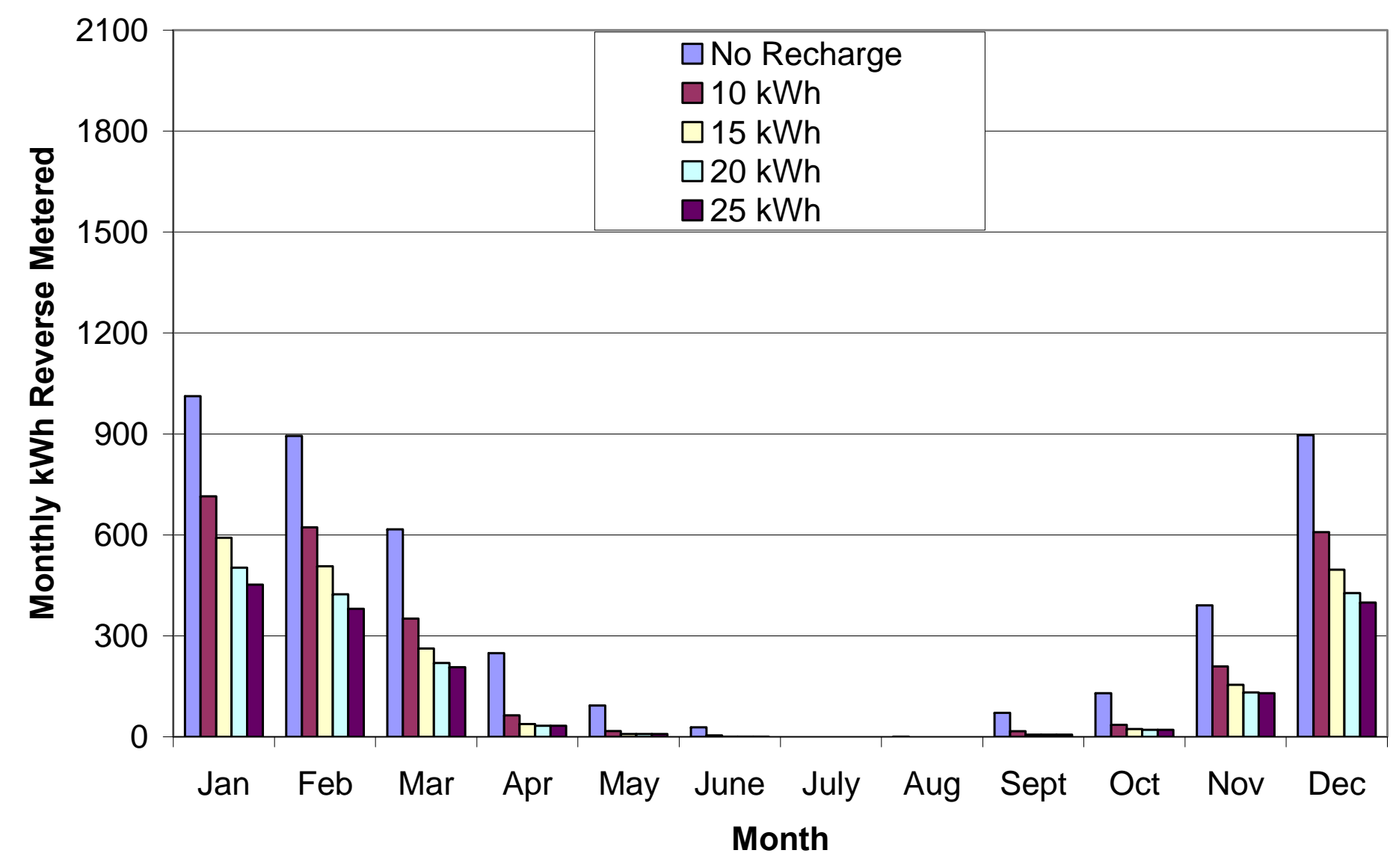

Figure 5-7. Monthly Reverse Metering for Various Car Battery Capacities, 3 kW System on Long Island (20\% Electric Efficiency) 
HYBRID CAR RECHARGE WITH REVERSE METERING 5kW SYSTEM ON LONG ISLAND, 20\% ELECTRIC EFFICIENCY

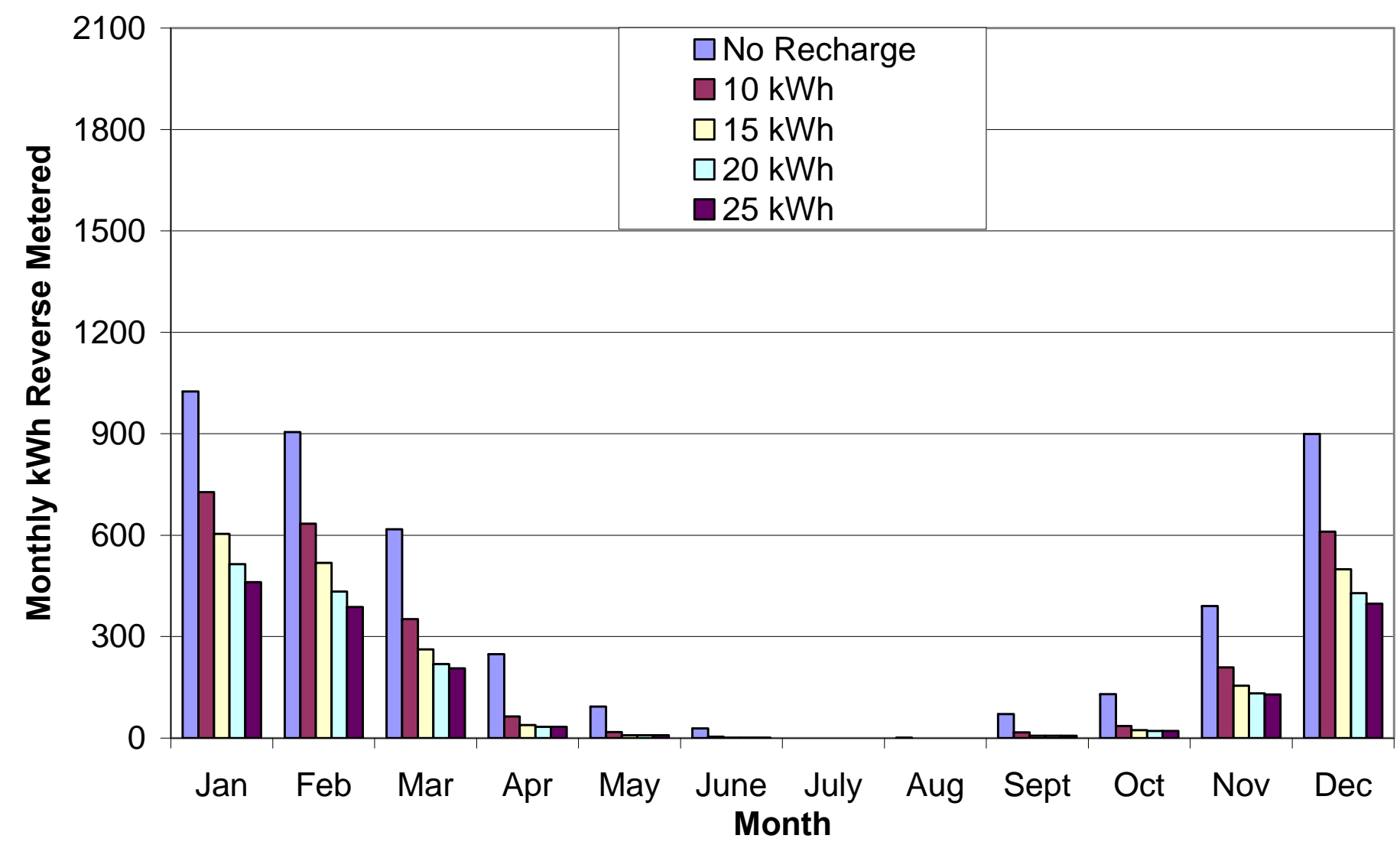

Figure 5-8. Monthly Reverse Metering for Various Car Battery Capacities, $5 \mathrm{~kW}$ System on Long Island (20\% Electric Efficiency) 
HYBRID CAR RECHARGE VS. REVERSE METERING IN ALBANY $25 \%$ ELECTRIC EFFICIENCY

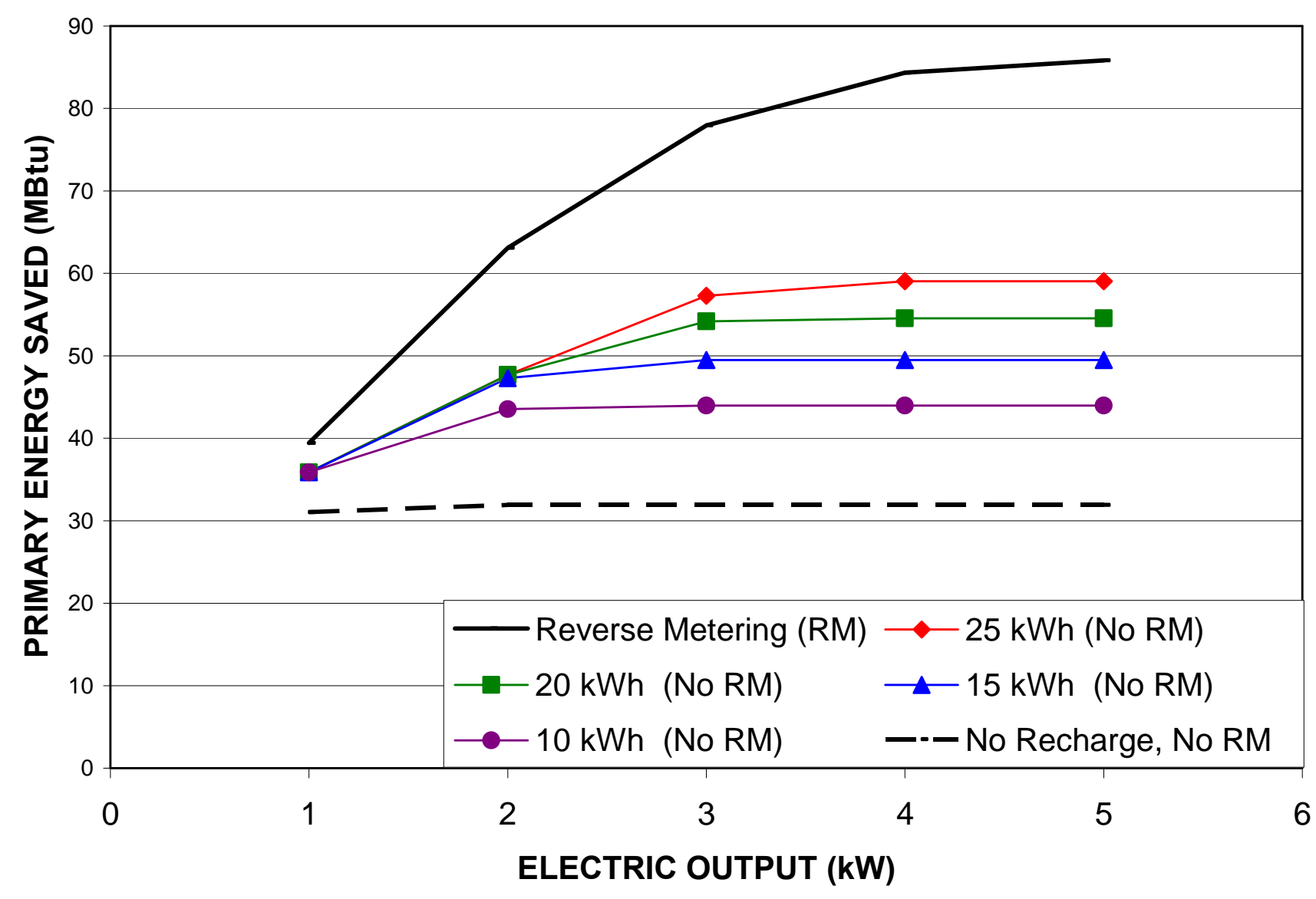

Figure 5-9. Energy Savings Comparisons, 25\% Electric Efficiency in Albany. (All curves are without reverse metering except the top one, which is the same whether or not electric-car recharge is included.) 


\section{HYBRID CAR RECHARGE VS. REVERSE METERING IN ALBANY}

$20 \%$ ELECTRIC EFFICIENCY

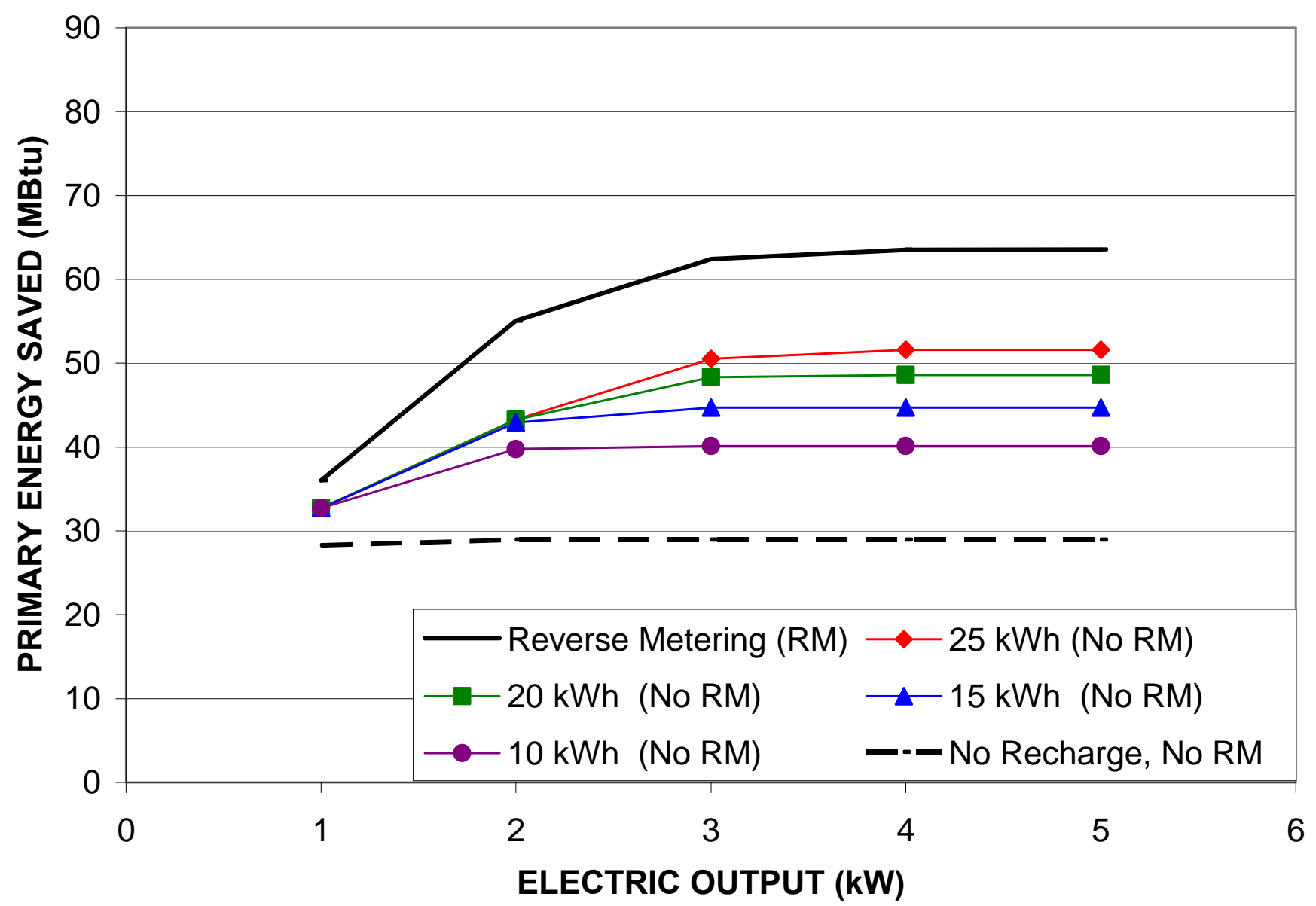

Figure 5-10. Energy Savings Comparisons, 20\% Electric Efficiency in Albany. (All curves are without reverse metering except the top one, which is the same whether or not electric-car recharge is included.) 
HYBRID CAR RECHARGE VS. REVERSE METERING ON LONG ISLAND 25\% ELECTRIC EFFICIENCY

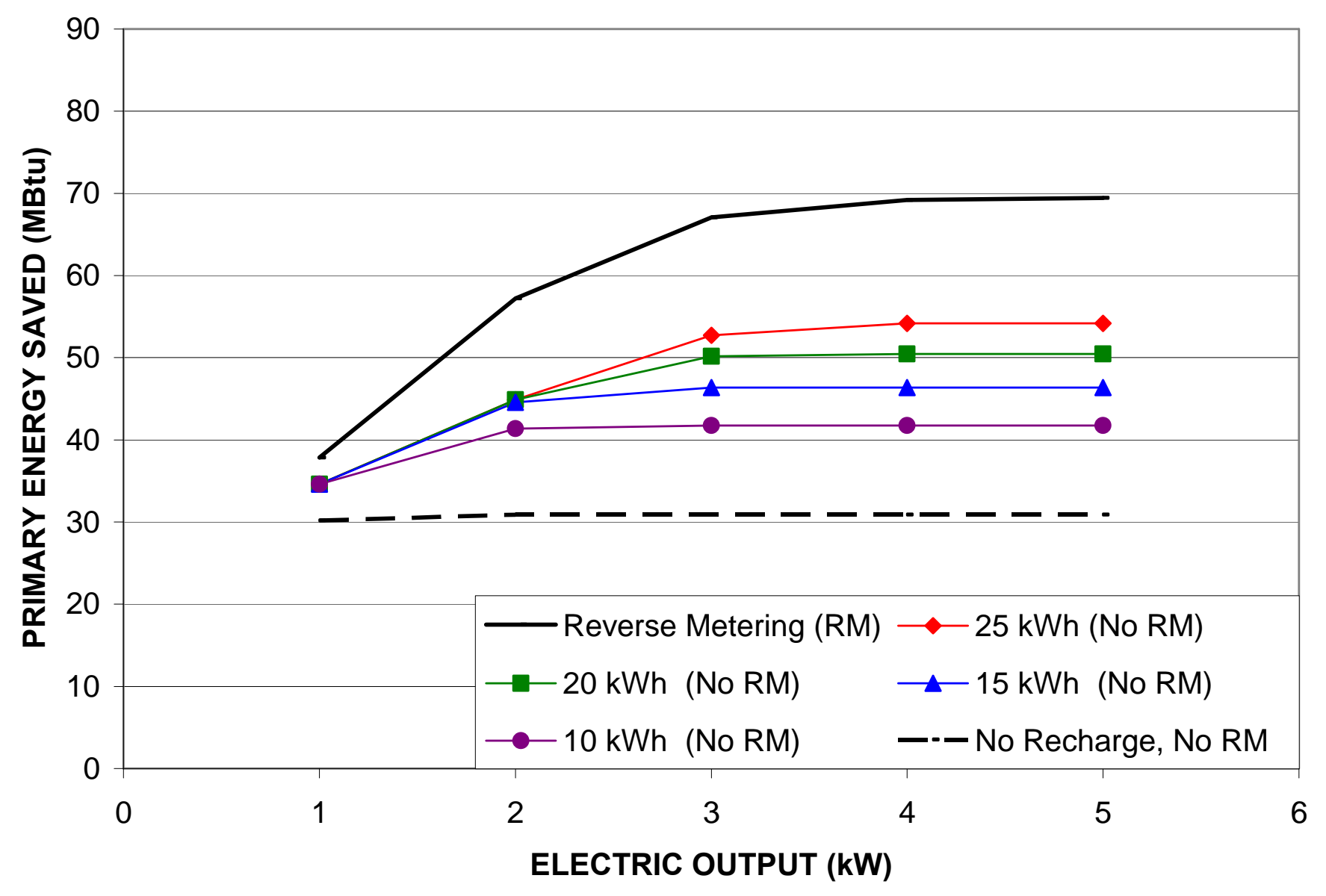

Figure 5-11. Energy Savings Comparisons, 25\% Electric Efficiency on Long Island. (All curves are without reverse metering except the top one, which is the same whether or not electric-car recharge is included.) 


\section{HYBRID CAR RECHARGE VS. REVERSE METERING ON LONG ISLAND}

$20 \%$ ELECTRIC EFFICIENCY

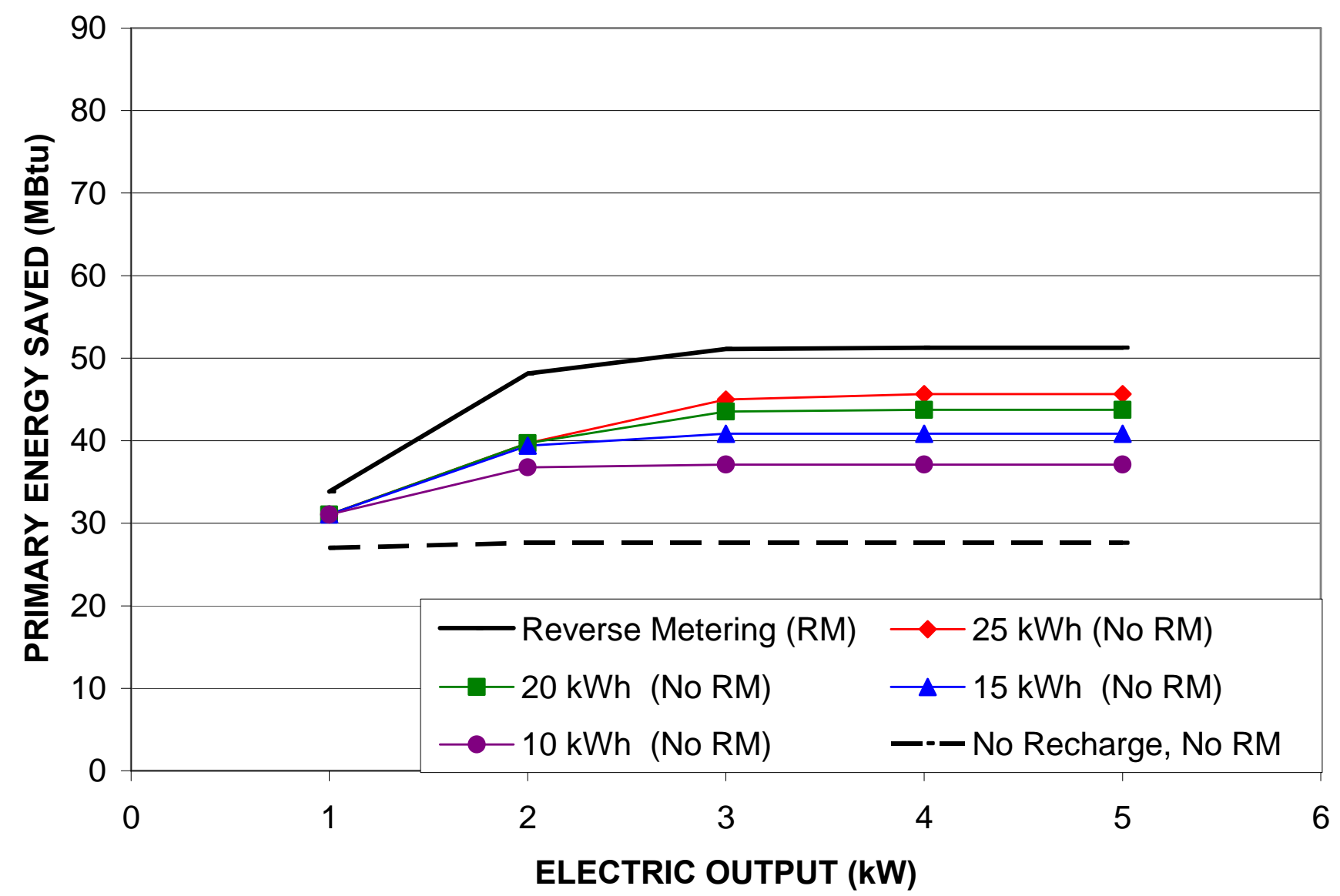

Figure 5-12. Energy Savings Comparisons, 20\% Electric Efficiency on Long Island. (All curves are without reverse metering except the top one, which is the same whether or not electric-car recharge is included.) 


\section{POTENTIAL UTILITY BENEFIT FROM OPERATION OF MICRO- COGENERATION SYSTEMS DURING PERIODS OF PEAK DEMAND}

\section{Analysis Description}

A typical mCHP system in a northern climate such as that of New York State will provide most of its operating hours during the winter heating season. During the summer, if operated on the basis of meeting thermal loads, the only heat sink available will be the domestic hot water tank. Thus, it is to be expected that under normal operation the system will be idle during much or most of the utility's periods of peak demand.

However, it might be possible to adjust the operating protocol of the system in such a way that it could contribute power to the house in which it is located and/or to the grid, specifically during those times when the utility would most like to see it functioning.

The following questions need to be addressed:

1. What economic value would such an operating protocol have to the utility, in terms of avoided cost of peak-power generation capacity?

2. Would such a protocol be feasible to implement in a way that would not add unacceptable monetary costs or homeowner inconvenience?

3. How could such benefits be shared between the homeowner and the utility so that both would have an incentive to participate?

\section{Economic Value of Available Generating Capacity}

Electric utilities typically have a range of generating means. Some are large central station plants that are typically base-loaded, i.e., intended to operate for as many hours of the year as possible. These may be expensive to build and have long lead times in their planning, but the fuel needs to be cheap. Both coal and nuclear fall into this category.

At the other end of the spectrum are facilities that are intended to be operated only during times of maximum demand. These are typically cheap to build, with short planning and construction lead times. The cost of fuel may be higher, but this is acceptable since the plants are only run for hundreds, rather than thousands, of hours per year. Typically, gas turbine and diesel-engine generators are used for this purpose.

A table of overnight capital costs for new projects in 2008 has been published by the U.S. Department of Energy (DOE/EIA 2009). (Overnight cost is the capital cost without interest or real cost escalation during construction.) These are summarized in the Table 6-1.

The lowest capital cost option is the combustion turbine, which is quoted as falling in a range of $\$ 604$ - \$638 per kW. We might therefore use this range as a benchmark for the economic value of avoiding the need for each $\mathrm{kW}$ of peak generation capacity. 
Table 6.1. Capital Costs of Various Power Generation Technologies

\begin{tabular}{|l|l|}
\hline $\begin{array}{l}\text { Capital Cost Category } \\
(\$ / \mathrm{kW})\end{array}$ & Technology Options \\
\hline$>\$ 3,000$ & $\begin{array}{l}\text { Fuel Cells } \\
\text { Biomass } \\
\text { Photovoltaic } \\
\text { Solar Thermal } \\
\text { Wind (Offshore) } \\
\text { IGCC* with Carbon Sequestration }\end{array}$ \\
\hline$\$ 2,000-\$ 3,000$ & $\begin{array}{l}\text { IGCC* } \\
\text { Advanced Nuclear } \\
\text { Landfill Gas } \\
\text { Conventional Hydropower in the Northwest }\end{array}$ \\
\hline$\$ 1,000-\$ 2,000$ & $\begin{array}{l}\text { Scrubbed Coal } \\
\text { Gas/Oil Combined Cycle with Carbon Sequestration } \\
\text { Distributed Generation } \\
\text { Geothermal } \\
\text { Wind (Onshore) }\end{array}$ \\
\hline$<\$ 1,000$ & $\begin{array}{l}\text { Gas/Oil Combined Cycle } \\
\text { Combustion Turbine }\end{array}$ \\
\hline
\end{tabular}

*IGCC $=$ Integrated Coal Gasification Combined Cycle

It is understood that a detailed evaluation would need to take other factors into account, such as any lost revenue to the utility from the avoided generator and any additional benefit in not having to plan for and manage the avoided generator. Perhaps the biggest unknown factor would be the cost of managing a large number of small generators that are not under direct utility ownership. This report will conclude with a suggestion concerning how this difficulty might be largely avoided.

\section{Operation of the mCHP System During Peak Periods}

One major question that must be addressed in any discussion of a peak-operation strategy is what to do with the waste heat? In normal operation, the space heating load and the domestic hot water (DHW) tank are the heat sinks. When these are satisfied, the system shuts down. Since in the summer there is no space heating load, the DHW tank is the only immediately available heat sink. So the options for rejecting waste heat boil down to two:

- Managing DHW production so that capacity will be available during utility peak-load periods.

- Adding a heat rejection means to the system.

Considering the second of these two options, one could imagine using a forced-air heating system as a "heat dump" if provision is made for ducting the heated air to the outside. Another option would be to short-circuit the water flow to the engine exhaust heat exchanger, allowing that portion of the engine heat to escape to the outside. Still another means would be to dump 
excess hot water to the drain. (The excess hot water might be used for lawn watering assuming that small droplets would cool sufficiently during their path through the air so that the lawn would not be harmed.)

Since any of the methods named in the preceding paragraph is likely to add (at least somewhat) to the cost and complexity of the system, let us examine the feasibility of the first option. This would presumably mean establishing a protocol whereby on days when the utility is likely to require system operation, the amount of hot water will be limited to actual demand, with a small section of stratified hot water at the top of the tank and the rest of the tank remaining cold. Thus, when in the afternoon of a peak day the utility calls for the system to begin operating, it would have an available sink in which to deposit the reject heat.

The question is, how long could a mCHP system operate before this heat sink is filled?

The answer will depend on several factors:

- The electrical output of the mCHP in $\mathrm{kW}$

- The electrical efficiency of the mCHP

- The amount of water in the tank that starts off cold

- The allowable temperature rise for this water.

- The normal demand for hot water during this period.

As an initial benchmark, let us assume a mCHP system whose electrical output is $2 \mathrm{~kW}$ and has an electrical efficiency of $25 \%$. Let us also assume 100 gallons of available cold water in the tank and an allowable $100{ }^{\circ} \mathrm{F}$ temperature rise. Let us also assume no hot water demand for simplicity and conservatism.

The output heat rate of the system is $2 \mathrm{~kW} X 3415 \mathrm{Btu} / \mathrm{kWh} / 0.25=27,000 \mathrm{Btu} / \mathrm{h}$. The available heat sink is $8.33 \mathrm{Btu} / \mathrm{gal}^{\circ}{ }^{\circ} \mathrm{F}$ X $100 \mathrm{gal} \mathrm{X} 100{ }^{\circ} \mathrm{F}=83,000 \mathrm{Btu}$. The operating time is then $83,000 / 27,000$ or approximately three hours.

It was assumed here that the amount of heat that needed to be rejected in the domestic hot water would be the same as under normal operation of the mCHP system. In practice, it should be practical to allow the engine exhaust to exit the system without extracting heat from it. This would require only an additional valve in the heat uptake system. It might also be possible to extract less jacket heat, allowing the engine to run at higher than normal temperatures.

Should the above expedients prove inadequate to the task, the operating time could be extended by simply "dumping" hot water into the drain. Clearly, one would not want to do this very often, but on an occasional basis it might be acceptable. To get an approximate cost, we need to ask how much a typical New York State customer pays for water. Most water utilities have a basic charge that includes a certain amount of water, whether one uses it or not. If one goes over the basic amount, then an additional charge of so much per gallon or per cubic foot is added.

If using the "emergency dump" strategy doesn't push the customer beyond the amount included in the basic charge, then the marginal cost of the strategy is zero. So let us assume that the customer is into the variable cost part of the rate schedule. Here are some rates within New York State, found from a brief survey of water utilities' Web sites. 


\begin{tabular}{|l|l|l|}
\hline Water Utility & $\begin{array}{l}\text { Rate for Usage in Excess of } \\
\text { Base Amount }\end{array}$ & $\begin{array}{l}\text { Rate in Cents per Cubic } \\
\text { Foot }\end{array}$ \\
\hline Freeport Village & $\$ 1.90$ per 1000 gallons & 1.42 \\
\hline Monroe County & $\$ 2.50$ per 1000 gallons & 1.88 \\
\hline Onandaga County & $\$ 2.12$ per 100 cubic feet & 2.12 \\
\hline Suffolk County & $\$ 1.09$ per 100 cubic feet & 1.09 \\
\hline & & $\mathbf{1 . 6 3}$ \\
Average & & \\
\hline
\end{tabular}

Let us assume on the basis of this (admittedly incomplete) sample that a customer will pay 2 cents per cubic foot of "wasted" water. One cubic foot (62 pounds) raised in temperature by $100{ }^{\circ} \mathrm{F}$ could absorb 6,200 Btu of heat. It would therefore require $\sim 4.5$ cubic feet of water to absorb the 27,000 Btu rejected in producing $2 \mathrm{kWh}$ of electricity, so this would work out to $\sim 4.5$ cents per $\mathrm{kWh}$. On a continuous basis this would clearly be an unacceptable add-on to the cost of electricity, but as an occasional measure that is needed only a few times per year, it seems insignificant. For example, if this strategy were used to add three hours to the on-peak operating time of the mCHP unit twice a month during the three summer months, this would add less than $\$ 2.00$ to the annual operating cost, and would make any perceptible capital outlay for an alternative heat rejection mechanism unattractive.

\section{Sharing the Benefits}

The net benefit to be shared between the utility and the customer would likely be less than the $\sim \$ 600$ per $\mathrm{kW}$ capital cost of the avoided generator. How much less is beyond the scope of this report to estimate. It is, however, useful to ask whether there are any strategies that could reduce any additional costs that would need to be subtracted from the $\$ 600$ "pie" that is to be split.

One suggestion that may be offered is for the utility to offer a reduced-rate plan for interruptible power during the summer months. Summer-peaking utilities tend to have split-rate fee schedules, charging more for electricity in the summer than in the winter. Suppose that, in return for a reduction or elimination of this differential, some customers would be willing to allow their power to be interrupted for a set number of hours each summer, depending on their own mCHP system to provide power during the interrupt periods. This would have the benefit of allowing a very simple protocol on the utility's part. Simply send a signal to a relay attached to the meter that interrupts power, perhaps with advance warning to allow the mCHP system to "fire up." The customer, of course, would need to have in place a protocol for managing their own hot water load and would need to prioritize power usages during the interrupt period. Whether this would be acceptable to enough customers to make it a worthwhile option (assuming the mCHP systems become widely marketed) is of course an unknown. The purpose here is merely to suggest it as an option. 


\section{Section VI Reference}

DOE/EIA 2009. Electricity Market Module. In U.S. Department of Energy Report Number DOE/EIA-0554 (2009), pp. 87-105. Table 8.1, p. 88. 


\section{COMPARISON OF CARBON EMISSIONS FROM MICRO- COGENERATION SYSTEMS AND GROUND-COUPLED HEAT PUMPS}

\section{Analysis Description}

As part of a recent conference on mCHP systems, a simulation study (Dorer and Weber 2008) compared mCHP systems with ground-coupled heat pumps. All the leading prime movers for the mCHP systems were included, i.e., internal combustion engine (ICE), polymer electrolyte membrane (aka proton exchange membrane) fuel cell (PEMFC), solid oxide fuel cell (SOFC), and Stirling engine. The salient conclusion was that the savings in primary energy and $\mathrm{CO}_{2}$ emissions of both the mCHP syatem and the ground-coupled heat pump depend importantly on the fuel mix and generation efficiency of the utility on which power from the grid is obtained. Ground-coupled heat pumps were found to be strong competitors to mCHP systems for both a standard European mix of electric generation technologies and also under the assumption of combined-cycle generation at the utility. In general, as the efficiency of utility power generation increases, the primary energy savings decreases for micro-CHP systems and increases for ground-coupled heat pumps.

The purpose of the present analysis is to quantify this effect for mCHP and GHCP performance parameters that are reasonable for New York State, as a function of the electric utility's mix of generation fuels. Characterization of the New York State average utility mix is part of the study.

\section{Efficiency of Ground-Coupled Heat Pumps}

The principal parameter needed to characterize a GCHP system for the purposes of this study is its coefficient of performance (COP). The COP is defined as the ratio of heat delivered by the system to the electricity required to operate it, with both energy quantities expressed in the same units. The COP can be stated on both an instantaneous and a seasonal average basis. For the purposes of this study, the seasonal average value was judged to be an adequate characterization.

The COP of electric resistance heat is 1.0. The purpose of a heat pump is to improve on this value. One benefit sought in GCHP systems is the reduction or elimination of the need for the electric-resistance backup heat that is usually required in air-source heat pump systems.

GCHP systems come in open-loop and closed-loop versions. The open-loop system uses a supply of standing or aquifer water, which is pumped to the unit, heat extracted from it, and pumped back to the source. A closed-loop system differs from this in that a heat-exchange fluid is pumped through a system of pipes embedded in the ground, with heat exchange taking place through the pipe walls.

There is no stock number that can be given to characterize the COP of a GCHP. For an openloop system, the main parameters include:

- Temperature of the water used as the heat source;

- Peak and average heating loads; 
- COP of the heat pump unit;

- Pump power needed to circulate the water from the source to the equipment and back;

- Other parasitic power, e.g., air distribution fans;

- Quality of the installation.

For a closed-loop system, the factors that this will depend on include the following:

- Size (length and bore) of the in-ground heat exchange loop;

- Thermal conductivity of the ground in which the loop is emplaced;

- Minimum and average temperature of the ground;

- Peak and average heating loads;

- Coefficient of performance (COP) of the heat pump unit;

- Pump power needed to circulate the heat-exchange fluid through the in-ground pipes.

- Other parasitic power, e.g., air distribution fans;

- Quality of the installation.

Most residential GCHP systems are closed-loop systems.

A Vermont study of three houses (Shapiro 2008) included in a review presentation at the National Renewable Energy Laboratory (Peterson 2008), quoted an average manufacturer's rated COP of 4.0, an average measured heat pump COP of 3.5, and an average system COP (taking parasitics into account) of 2.8. These numbers are probably not far from typical for a northernclimate installation. For this study, a COP range of 2.0 to 4.0 was used for the GCHP.

\section{Characterization of the mCHP System}

The micro-cogeneration system is characterized and modeled as described in Section II. From the many simulation runs reported on earlier, the following have been selected for comparison with the GCHP system:

- Locations in Albany and on Long Island

- Oil Fired and Gas Fired

- Electrical Outputs of $1 \mathrm{~kW}, 2 \mathrm{~kW}$, and $3 \mathrm{~kW}$

- Electrical Efficiencies of $25 \%$ and $20 \%$

- Heating, Cooling and DHW Loads All Turned On

- mCHP System is Grid Connected

It was considered important to treat both the upstate and downstate locations, and to consider both gas and oil as fuels for the mCHP systems. Electrical outputs higher than $3 \mathrm{~kW}$ were not found to change the results perceptibly, so they were not included. In order to have a fair comparison of systems, all loads had to be treated under both sides of the comparison. Finally, grid connection with reverse metering was seen as a way to get the maximum benefit for the mCHP system. These choices provide a matrix of 24 cases for comparison.

\section{Characterizing the Utility's Carbon Dioxide Emissions}


For the purposes of this study, the salient parameter characterizing the electric utility, from the point of view of the homeowner's overall carbon dioxide emissions, is the mass of $\mathrm{CO}_{2}$ emitted per kilowatt-hour of electricity generated. For electricity generated from fossil fuels, this parameter depends on two underlying factors: the carbon content of the fuel and the efficiency of the process used to convert the energy stored in the fuel to useful electric energy.

It turns out that the utility emissions parameter ranges from essentially zero (for nuclear and hydroelectric power) to about one (for current-generation coal-fired power plants). It is thus a handy and easily visualized measure. It can also be stated in grams per kilowatt-hour $(\mathrm{g} / \mathrm{kWh})$, in which case the values range from zero to about 1,000 .

According to the U.S. Energy Information Agency (DOE/EIA 2009a), the $\mathrm{CO}_{2}$ emissions from fossil fuels, per million Btu of energy content, are as shown in table 7-1. From this table, it is possible to calculate the utility $\mathrm{CO}_{2}$ emissions parameter, in $\mathrm{g} / \mathrm{kWh}$, if one knows the efficiency of generation. The following table gives the results for two efficiency levels: $33 \%$ (representing conventional technologies) and 45\% (representing next-level combined cycle processes). These efficiencies are, of course, approximations. It should also be noted that the values quoted below include only the on-site $\mathrm{CO}_{2}$ emissions, and not indirect emissions associated with fuel procurement and plant construction, operation, and decommissioning. These are discussed briefly below.

Table 7-1. Carbon Dioxide Emissions by Fuel, Related to Energy Content

\begin{tabular}{|l|l|}
\hline Fuel & Pounds $\mathrm{CO}_{2}$ per million Btu \\
\hline Coal & \\
\hline Anthracite & 227.4 \\
\hline Bituminous & 205.3 \\
\hline Subbituminous & 212.7 \\
\hline Lignite & 215.4 \\
\hline Used in this study (see below) & 209.0 \\
\hline Oil & \\
\hline Distillate (\#1,\#2,\#4) & 161.4 \\
\hline Residual (\#5,\#6) & 173.9 \\
\hline Natural Gas & \\
\hline Pipeline Gas & 117.1 \\
\hline
\end{tabular}

For coal, a heat content intermediate between bituminous and subbituminous/lignite was used (209.0 pounds $\mathrm{CO}_{2}$ per million Btu) in recognition of the fact that very little anthracite coal is used for electric power generation. The carbon-dioxide emissions parameters, by fuel and generation efficiency, are then as shown in Table 7-2.

It is striking that, even within the category of fossil fuels and generation efficiencies achievable with existing technology, these values differ by a factor of 2.5. The variability increases even further when differing amounts (from one utility to another or one state to another) of nuclear and renewable energy are factored in. For these energy sources, the carbon emissions are essentially zero. 
Table 7-2. Utility Carbon-Dioxide Emissions Parameter, g/kWh

\begin{tabular}{|c|c|c|}
\hline \multirow{2}{*}{ Fuel } & \multicolumn{2}{|c|}{ Efficiency } \\
\hline & $33 \%$ & $45 \%$ \\
\hline Coal & 980 & 720 \\
\hline Oil (Residual) & 820 & 600 \\
\hline Natural Gas & 550 & 400 \\
\hline
\end{tabular}

A full accounting of emissions, including the carbon generated during plant construction, operation, and decommissioning (and for fuel processing, in the case of nuclear) shows that even these "carbon-free" sources do emit some $\mathrm{CO}_{2}$. The amounts are extremely small, however. According to a Swiss study (Hirschberg and Dones 2001), the following $\mathrm{CO}_{2}$ emissions can be attributed to various carbon-free sources (Table 7-3):

Table 7-3. $\mathrm{CO}_{2}$ Emissions from "Carbon-Free" Energy

\begin{tabular}{|l|c|}
\hline Energy Source & $\begin{array}{l}\mathrm{CO}_{2} \text { emissions attributable to } \\
\text { indirect causes }(\mathrm{g} / \mathrm{kWh})\end{array}$ \\
\hline Hydroelectric & 4 \\
\hline Nuclear & 16 \\
\hline Wind & 36 \\
\hline Photovoltaic & 121 to 193 \\
\hline
\end{tabular}

The values for hydroelectric and nuclear power are small enough to ignore for the purposes of this study. (Parenthetically, we have already noted that the emissions levels used for fossil fuels do not include these indirect sources of carbon, either.) According to the same study, those range from $\sim 50$ to $\sim 150 \mathrm{~g} / \mathrm{kWh}$, much larger values than those for nuclear, hydroelectric, or wind power, and comparable to photovoltaics.

A key question for the purposes of this study is where New York State's utilities lie on the carbon emissions spectrum. The U.S. Energy Information Agency (DOE/EIA 2009b) lists the values of the utility $\mathrm{CO}_{2}$ emissions parameter by state in metric tons per $\mathrm{MWh}$, which is the same as $\mathrm{kg} / \mathrm{kWh}$ and is easily converted to $\mathrm{g} / \mathrm{kWh}$ by multiplying by 1000 . These range from a high of $1017 \mathrm{~g} / \mathrm{kWh}$ for North Dakota (reflecting its near-total dependence on coal, a large fraction of which is lignite) to a low of 13 for Vermont and Idaho (reflecting their near-total dependence on nuclear and hydroelectric power). New York State is twelfth-lowest at $389 \mathrm{~g} / \mathrm{kWh}$.

One might ask whether it is possible for New York to be this low, in view of the values for fossil fuels quoted above. The answer lies in the fact that New York uses more nuclear and hydroelectric power and less coal than the U.S. average. A cross check can be obtained from the New York State Energy Plan (NYSERDA 2002), which lists the fuel mix for New York State based on energy produced (Table 7-4).

If one assumes 33\% efficiency for the fossil fuel generators, zero carbon emissions for "other" (assuming it to be largely renewable), and net imports having the same carbon footprint per kWh as in-state generation, one obtains a utility carbon emissions factor of $431 \mathrm{~g} / \mathrm{kWh}$. Doing the same calculation assuming that net imports produce no carbon emissions (clearly a mistake) would yield $380 \mathrm{~g} / \mathrm{kWh}$. One might conclude that the DOE/EIA figure is therefore too low. On 
the other hand, boosting the average efficiency of fossil-fuel generation by four percentage points (to $37 \%$ ) is enough to reproduce the DOE/EIA figure.

Table 7-4. New York State Utility Generation Mix

\begin{tabular}{|l|c|}
\hline Generator Fuel & Percent of Output \\
\hline Natural Gas & 25.0 \\
\hline Oil & 9.8 \\
\hline Coal & 15.7 \\
\hline Nuclear & 20.1 \\
\hline Hydropower & 15.5 \\
\hline Other & 2.0 \\
\hline Net Imports & 11.9 \\
\hline
\end{tabular}

However that may be, it seems reasonable to assume that New York State's utility carbondioxide emissions parameter is close to 0.4 and almost certainly less than 0.5 . This will be important in the comparison of carbon emissions for residential mCHP and GCHP systems.

\section{$\underline{\text { Results }}$}

The results of the comparisons are shown in Figures 7-1 through 7-8. In each case, the horizontal axis is the utility carbon-dioxide emissions parameter, given in $\mathrm{kg} / \mathrm{kWh}$ (range of axis zero to one). The vertical axis is the annual mass of $\mathrm{CO} 2$ attributed to the system in question.

Four system types are shown:

- The red line shows a conventional system using an $85 \%$-efficient furnace or boiler (with the efficiency being the average for space heat and DHW), combined with reliance on grid power for all the homes electricity needs.

- The green line shows an all-electric system that uses electric resistance $\left(I^{2} R\right)$ for space and water heating.

- The blue lines show GCHP systems with COP values ranging from 2 to 4.

- The black lines show mCHP systems with electrical outputs ranging from $1 \mathrm{~kW}$ to $3 \mathrm{~kW}$.

The salient results can be summarized as follows:

1. The GCHP systems produce the lowest carbon emissions when the utility emissions parameter value is toward the low end of the spectrum.

2. The mCHP systems produce the lowest carbon emissions when the utility emissions parameter value is toward the high end of the spectrum.

3. Depending on location, $\mathrm{mCHP}$ fuel, mCHP electric output, mCHP electric efficiency, and GCHP COP, the curves for mCHP and GCHP emissions cross within the interval $0.3 \mathrm{~kg} / \mathrm{kWh}$ to $0.7 \mathrm{~kg} / \mathrm{kWh}$ on the utility emissions parameter. The average utility emissions parameter for New York State utilities falls within this range. 


\section{Use of Biodiesel}

The use of biodiesel in an oil-fired mCHP system can significantly reduce its carbon-dioxide emissions. According to a report from the National Renewable Energy Laboratory (Sheehan et al. 1998), biodiesel reduces net emissions of $\mathrm{CO}_{2}$ by $78.45 \%$ compared to petroleum diesel. If this is used as a benchmark and the carbon content of diesel is reduced by this same percentage, a revised chart of carbon-dioxide emissions is obtained. This is shown in Figure 7-9 for Albany and Figure 7-10 for Long Island, in both cases using an mCHP system with 25\% electric efficiency. In these comparisons the "conventional" system is also biodiesel fired.

It can be seen that this changes the picture dramatically. In the extreme case of a biodiesel $\mathrm{mCHP}$ in a region with a coal-fired utility, carbon emissions drop essentially to zero. In the case of Albany, they can even go negative. This perhaps deserves a bit of explanation. It isn't that the mCHP system suddenly absorbs carbon from the atmosphere. Instead, the power sold to the utility reduces its emissions by a larger amount than the emissions of the mCHP system itself.

Relevant to New York State, the crossover point where the mCHP carbon emissions become less than those for the GCHP drops to less than 0.15, meaning that the biodiesel-fired $\mathrm{mCHP}$ is better, from a carbon-emissions standpoint, than the GCHP in New York.

These results, of course, assumed $100 \%$ biodiesel. Current efforts to employ this fuel usually envision a blend of biodiesel with petroleum diesel. It therefore seemed useful to examine the impacts of using blends. For this study, two blends were considered:

- $\quad$ B20 (20\% biodiesel and 80\% petroleum diesel)

- B50 (50\% biodiesel and 50\% petroleum diesel)

The results are shown in Figures 7-11 through 7-14. As one would expect, the results are intermediate between those for pure biodiesel and pure petroleum diesel. For an electric utility with a carbon emissions factor of $0.4 \mathrm{~kg} / \mathrm{kWh}$, representative of New York State's average, the results can be summarized as follows:

- Using B20, the MCHP system's carbon emissions are similar to those of a GCHP with a COP of 2.

- Using B50, the MCHP system's carbon emissions are similar to those of a GCHP with a COP of 3 to 4.

Several factors should be kept in mind here. For one thing, it is far easier to achieve an annual average COP of 2 in a residential GCHP system than it is to achieve a COP of 4 . Second, although New York State's average utility emissions factor is approximately $0.4 \mathrm{~kg} / \mathrm{kWh}$, this value varies by region. Given the fact that power is wheeled from one region to another and also across state lines, delineating these emissions factors by location within the state would require significant additional effort. What can be said here is that it is likely that from a carbon emissions standpoint, the relative merits of these various systems will be region-dependent. 


\section{Conclusions}

This section draws two main conclusions:

1. Residential-scale combined heat and power (mCHP) systems could contribute to an electric utility's generating capacity. To be available when it is needed, during times of summer peak demand, means for rejecting heat produced by the system but not needed by the household are required. This may be achieved by managing the timing of domestic hot water production combined with occasional "dumping" of excess hot water as a fallback option.

2. The relative levels of carbon-dioxide emissions of mCHP systems and ground-coupled heat pump (GCHP) systems depends on the carbon-dioxide emissions rate (in mass of carbon dioxide per unit of electric energy produced) of the electric utility to which the system is connected. For utilities with low carbon-dioxide emissions rates, the GCHP systems have the smallest carbon "footprints." For utilities with high carbon-dioxide emissions rates, the mCHP systems rank lowest in carbon emissions. If the mCHP system is able to use $100 \%$ biodiesel as its fuel, it ranks lowest in carbon emissions for all but the very lowest utility carbon emissions rates. Biodiesel blends give results intermediate between those for pure biodiesel and petroleum diesel.

\section{$\underline{\text { Section VII References }}$}

DOE/EIA 2009a. "Voluntary Reporting of Greenhouse Gases Program." Accessed on the Internet at www.eia.doe.gov/1605/coefficients.html (August 11, 2009).

DOE/EIA 2009b. "Voluntary Reporting of Greenhouse Gases Program." Accessed on the Internet at www.eia.doe.gov/1605/ee-factors.html (August 11, 2009).

Dorer, V. and A. Weber 2008. "Performance Assessment of Micro-Cogeneration Systems in Residential Buildings with Different Energy Demand Levels." First International Conference and Workshop on Micro-Cogeneration and Applications. Ottawa, Canada, April 28 - May 2, 2008.

Hirschberg, S. and R. Dones 2001. "Analytical Decision Support for Sustainable Electricity Supply.” Paul Sherrer Institut, CH-5232 Villigen PSI, Switzerland.

NYSERDA 2002. New York State Energy Plan, Section 3.4, Electricity Resource Assessment, June 2002. Table 8. Accessed on the Internet on August 28, 2009, at www.nyserda.org/sep/sepsection3.4.pdf

Peterson, D. 2008. Ground Source Heat Pumps: An Introduction. PowerPoint presentation at the National Renewable Energy Laboratory.

Shapiro, A. 2008. Ground Source Heat Pumps: Design for Performance. Archived on the World Wide Web at www.efficiencyvermont.com/pages/BBBD2008. 


\section{GCHP vS MCHP 25\% ELECTRIC EFFICIENCY, ALBANY, OIL FIRED}

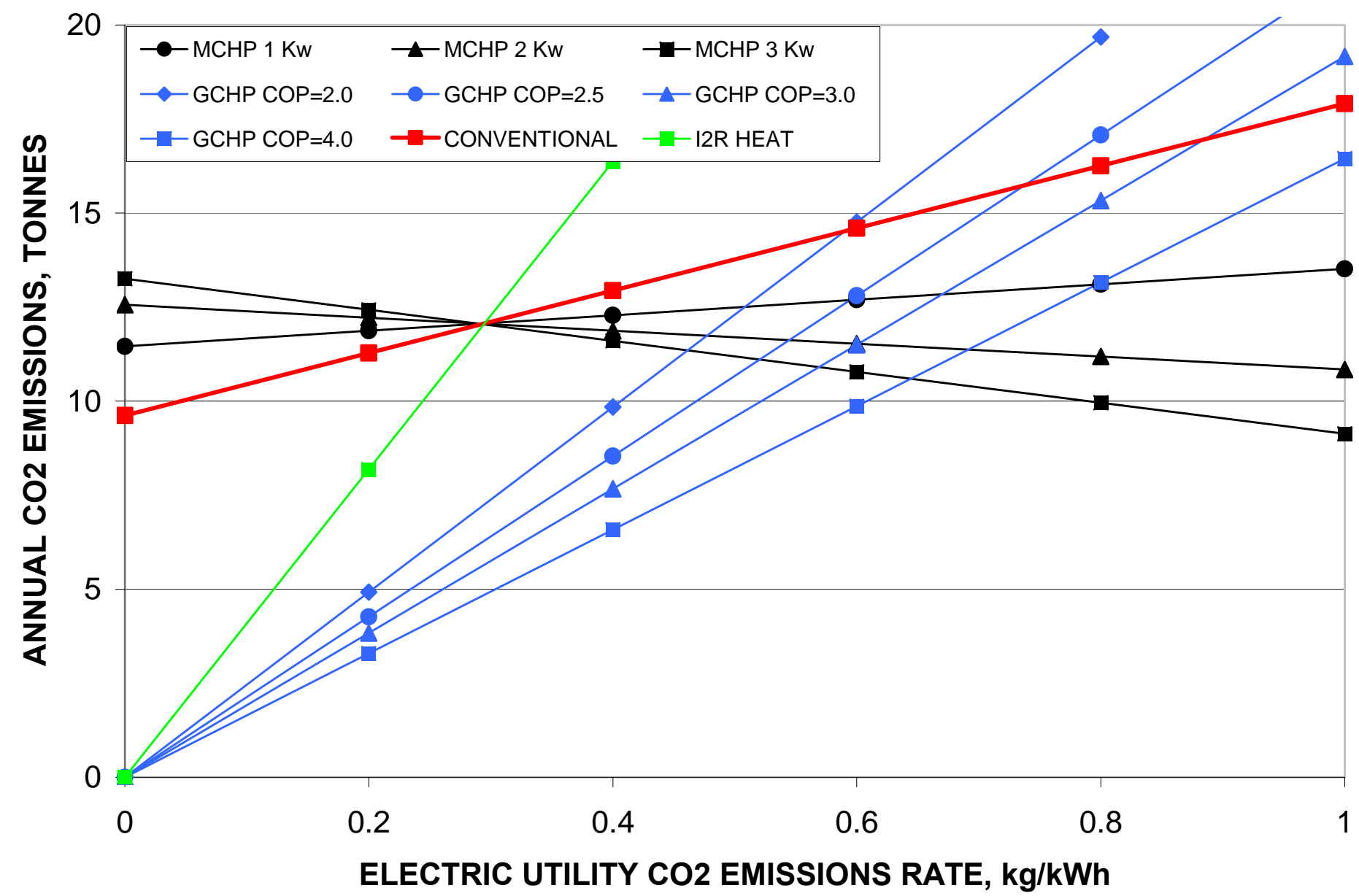

Figure 7-1. Carbon Dioxide Emissions Comparison as a Function of Electric Utility Emissions, Oil-Fired mCHP with 25\% Electric Efficiency in Albany 
GCHP vs MCHP 25\% ELECTRIC EFFICIENCY, ALBANY, GAS FIRED

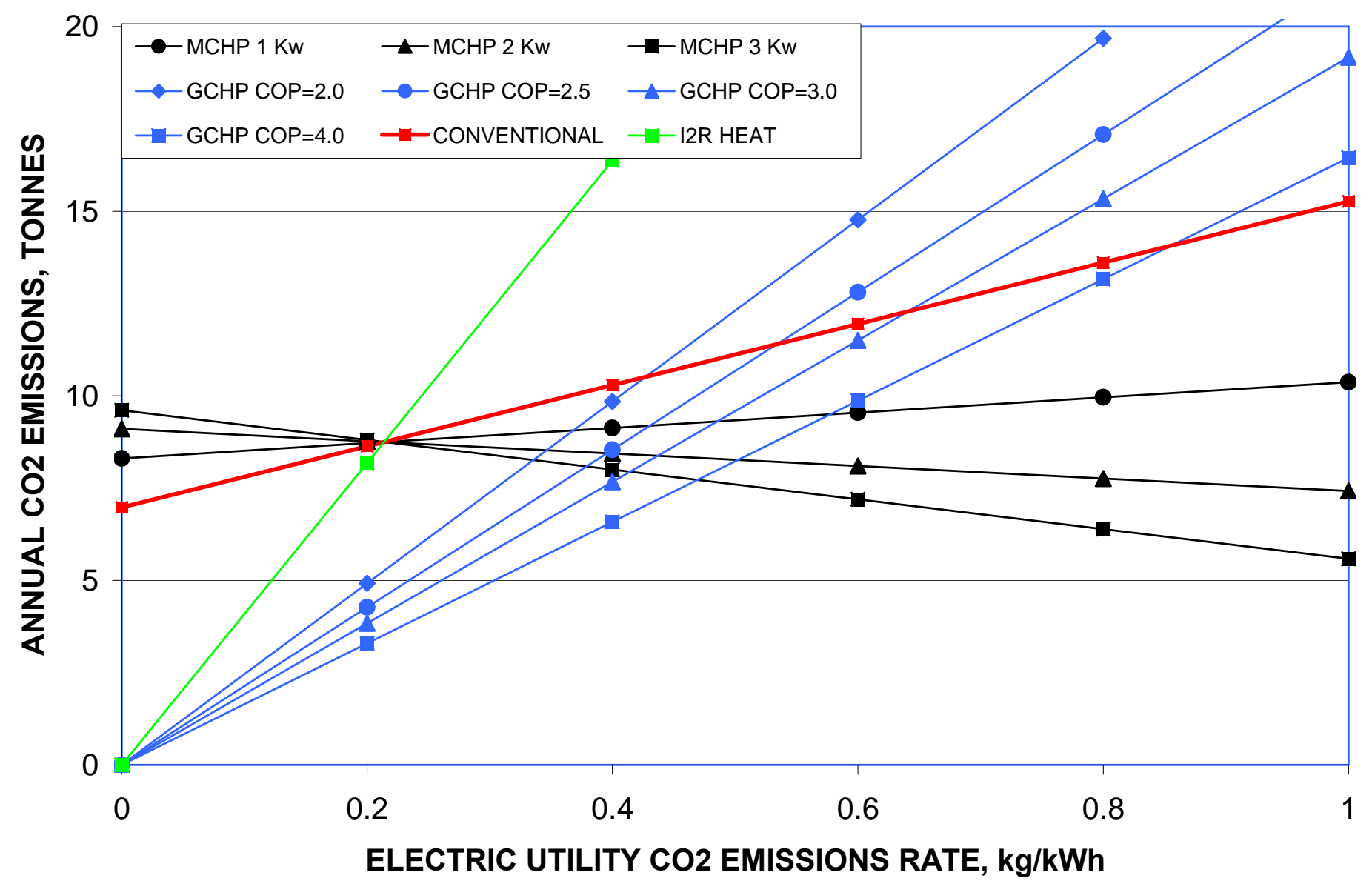

Figure 7-2. Carbon Dioxide Emissions Comparison as a Function of Electric Utility Emissions, Gas-Fired mCHP with 25\% Electric Efficiency in Albany 
GCHP vs MCHP $20 \%$ ELECTRIC EFFICIENCY, ALBANY, OIL FIRED

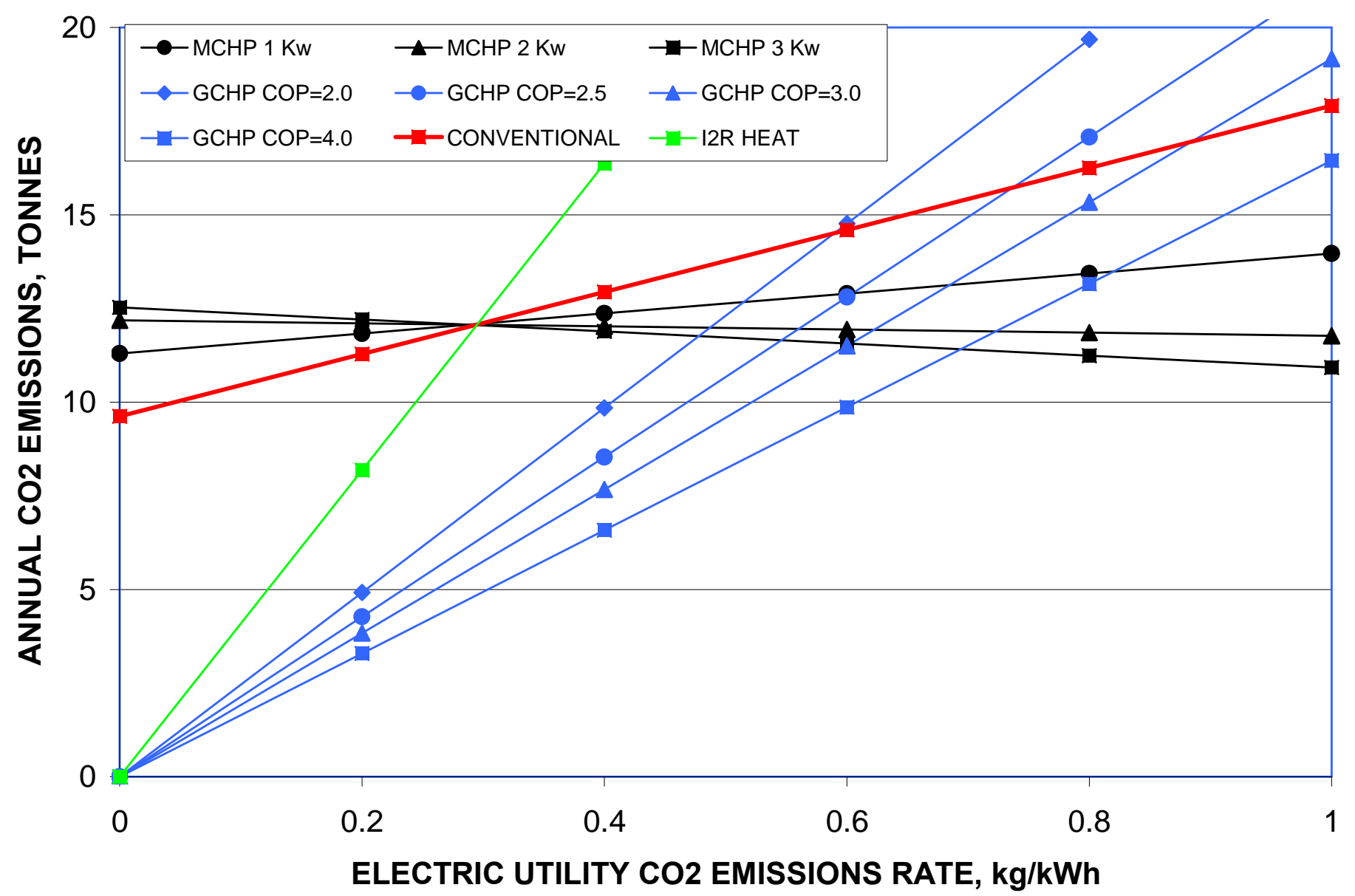

Figure 7-3. Carbon Dioxide Emissions Comparison as a Function of Electric Utility Emissions, Oil-Fired mCHP with 20\% Electric Efficiency in Albany 


\section{GCHP vs MCHP $20 \%$ ELECTRIC EFFICIENCY, ALBANY, GAS FIRED}

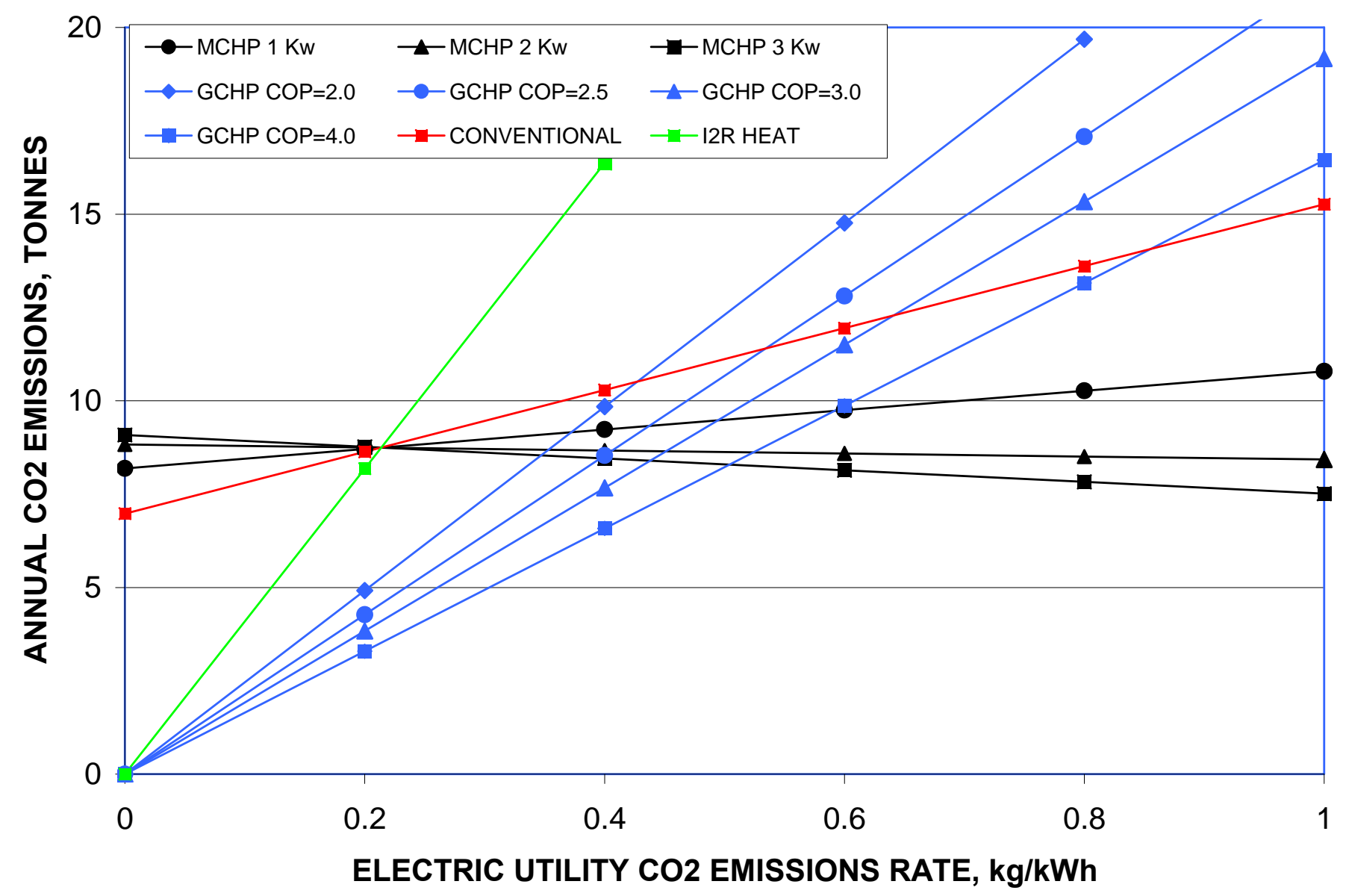

Figure 7-4. Carbon Dioxide Emissions Comparison as a Function of Electric Utility Emissions, Gas-Fired mCHP with 20\% Electric Efficiency in Albany 
GCHP vs MCHP 25\% ELECTRIC EFFICIENCY, LONG ISLAND, OIL FIRED

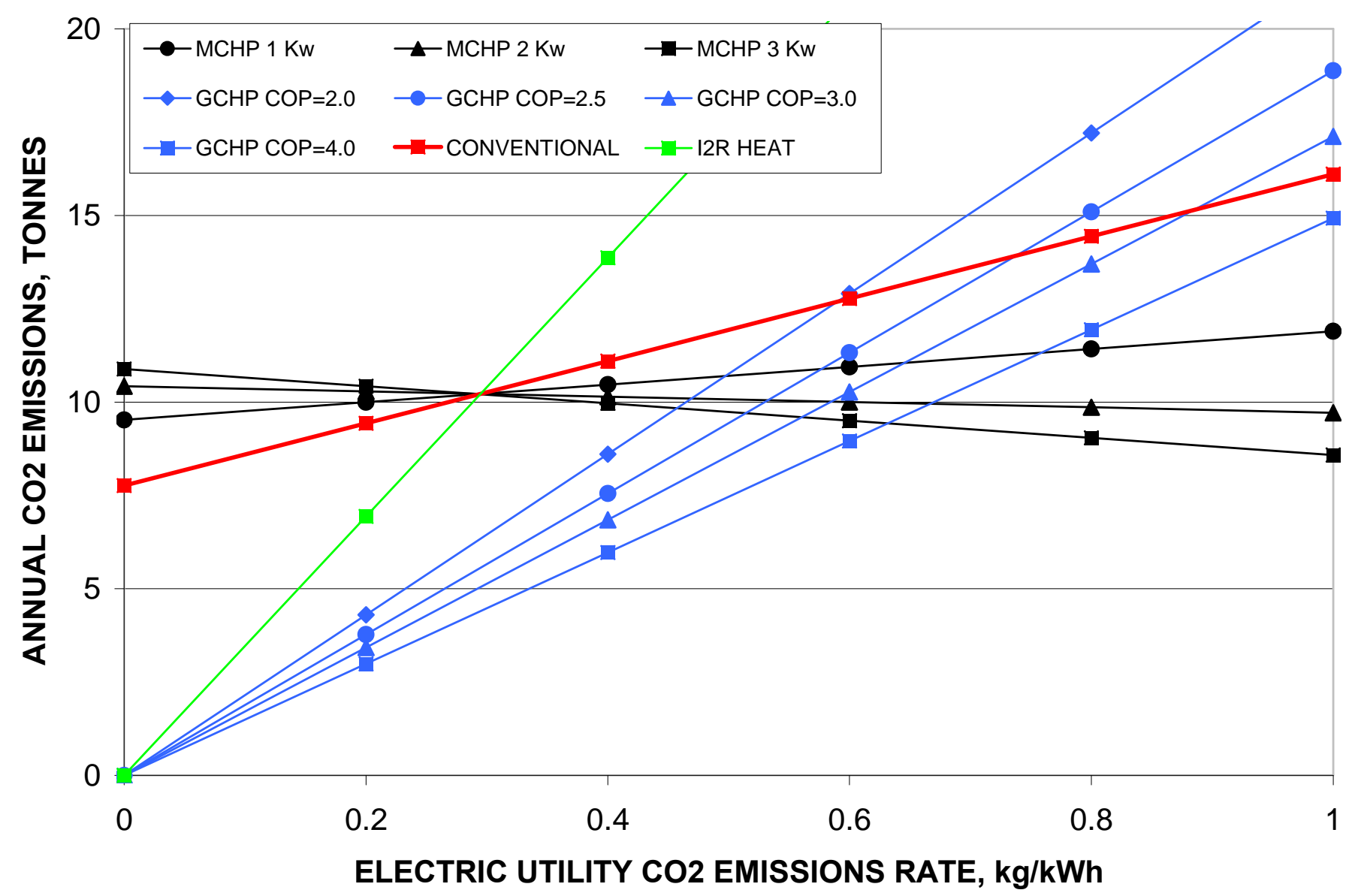

Figure 7-5. Carbon Dioxide Emissions Comparison as a Function of Electric Utility Emissions, Oil-Fired mCHP with 25\% Electric Efficiency on Long Island 


\section{GCHP vs MCHP 25\% ELECTRIC EFFICIENCY, LONG ISLAND, GAS FIRED}

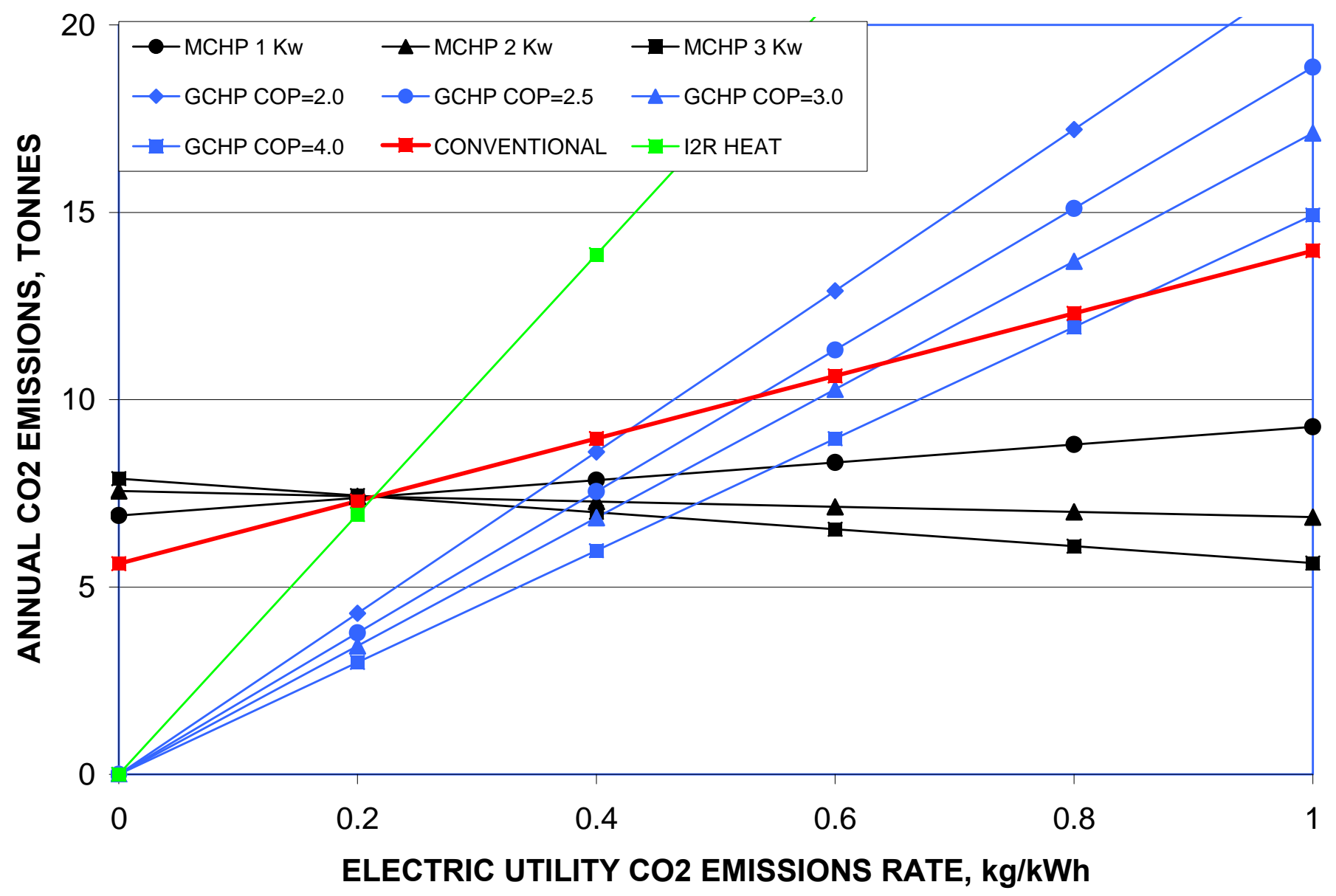

Figure 7-6. Carbon Dioxide Emissions Comparison as a Function of Electric Utility Emissions, Gas-Fired mCHP with 25\% Electric Efficiency on Long Island 


\section{GCHP vs MCHP 20\% ELECTRIC EFFICIENCY, LONG ISLAND, OIL FIRED}

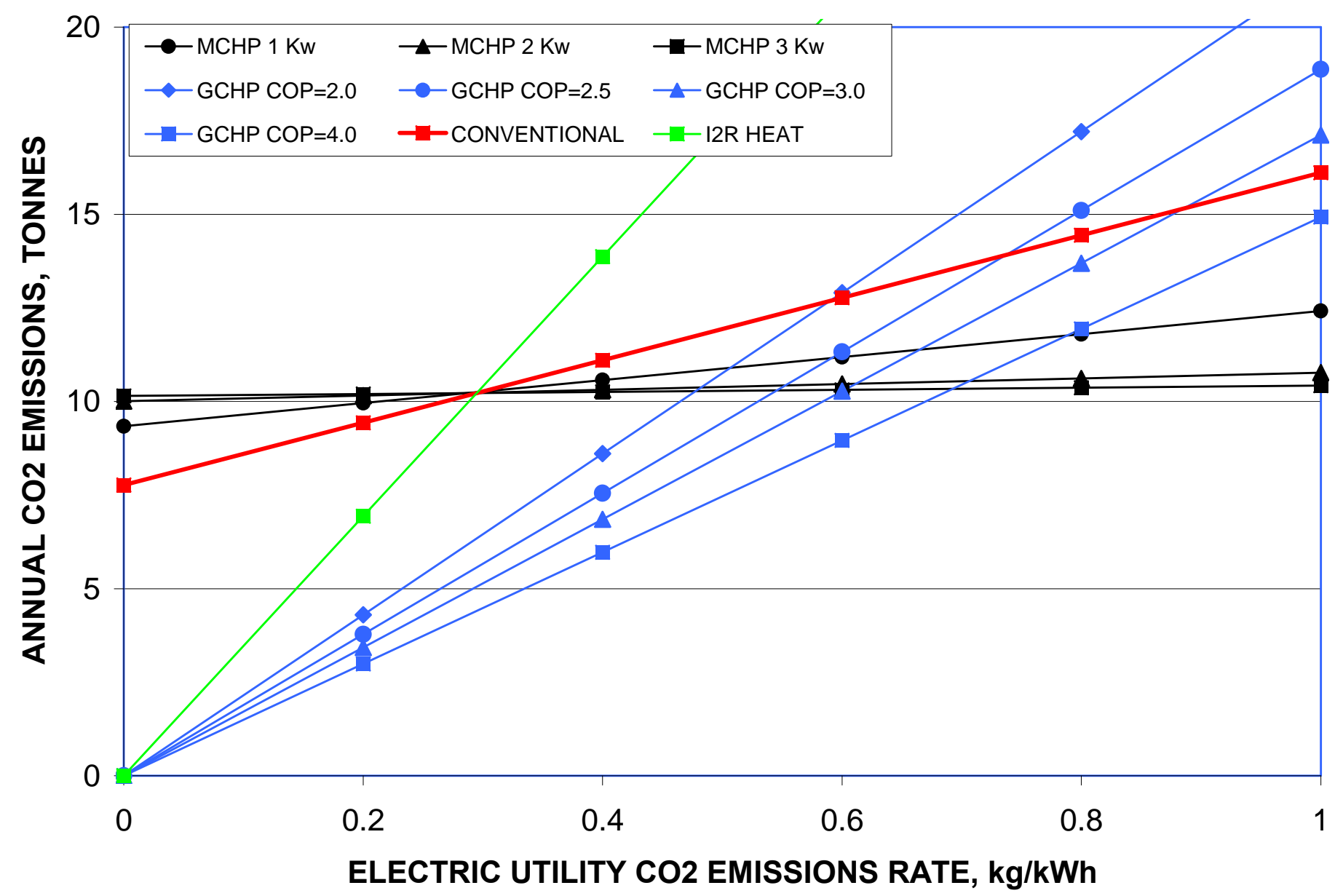

Figure 7-7. Carbon Dioxide Emissions Comparison as a Function of Electric Utility Emissions, Oil-Fired mCHP with 20\% Electric Efficiency on Long Island 


\section{GCHP vS MCHP 20\% ELECTRIC EFFICIENCY, LONG ISLAND, GAS FIRED}

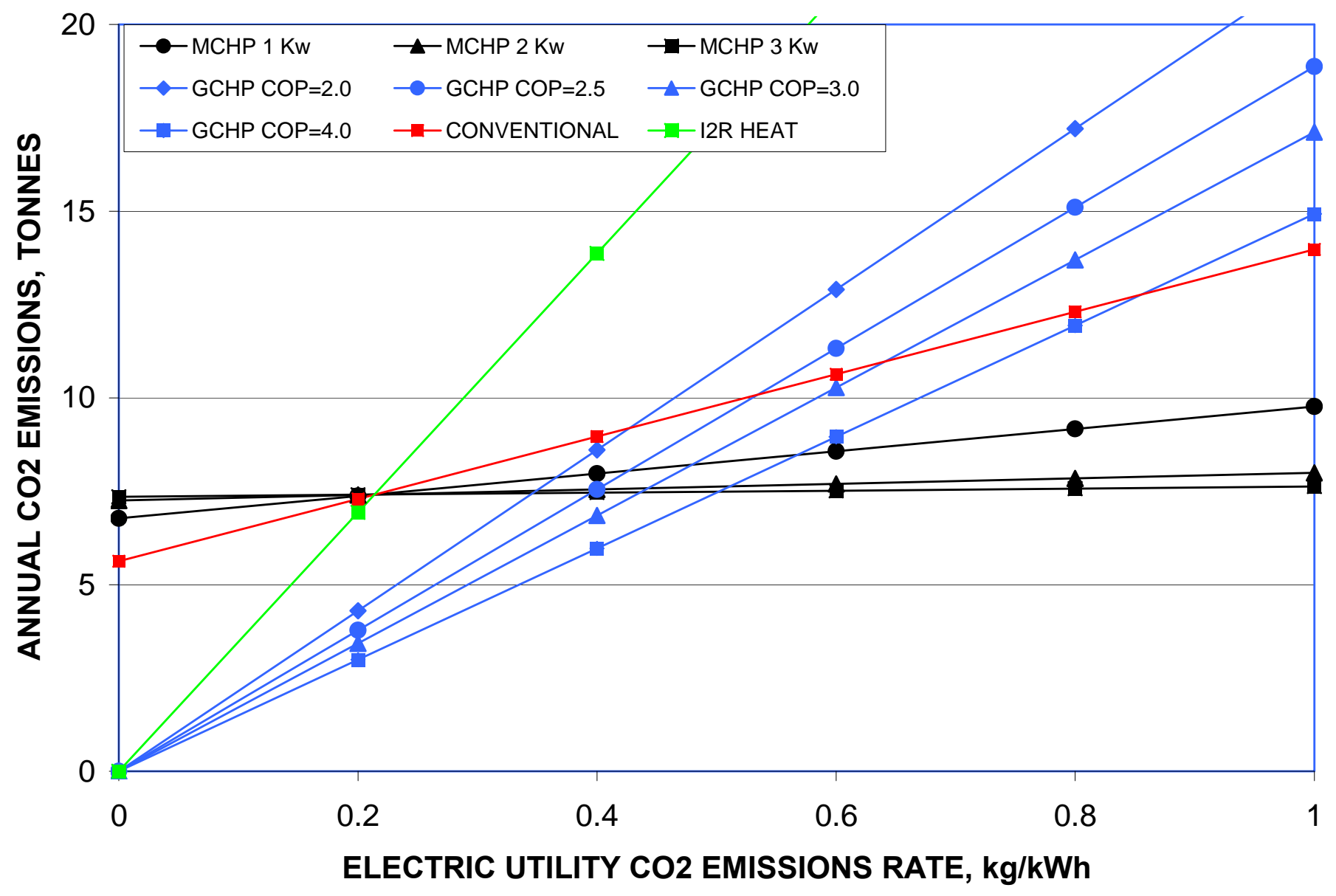

Figure 7-8. Carbon Dioxide Emissions Comparison as a Function of Electric Utility Emissions, Gas-Fired mCHP with 20\% Electric Efficiency on Long Island 
GCHP vs MCHP 25\% ELECTRIC EFFICIENCY, ALBANY, BIODIESEL FIRED

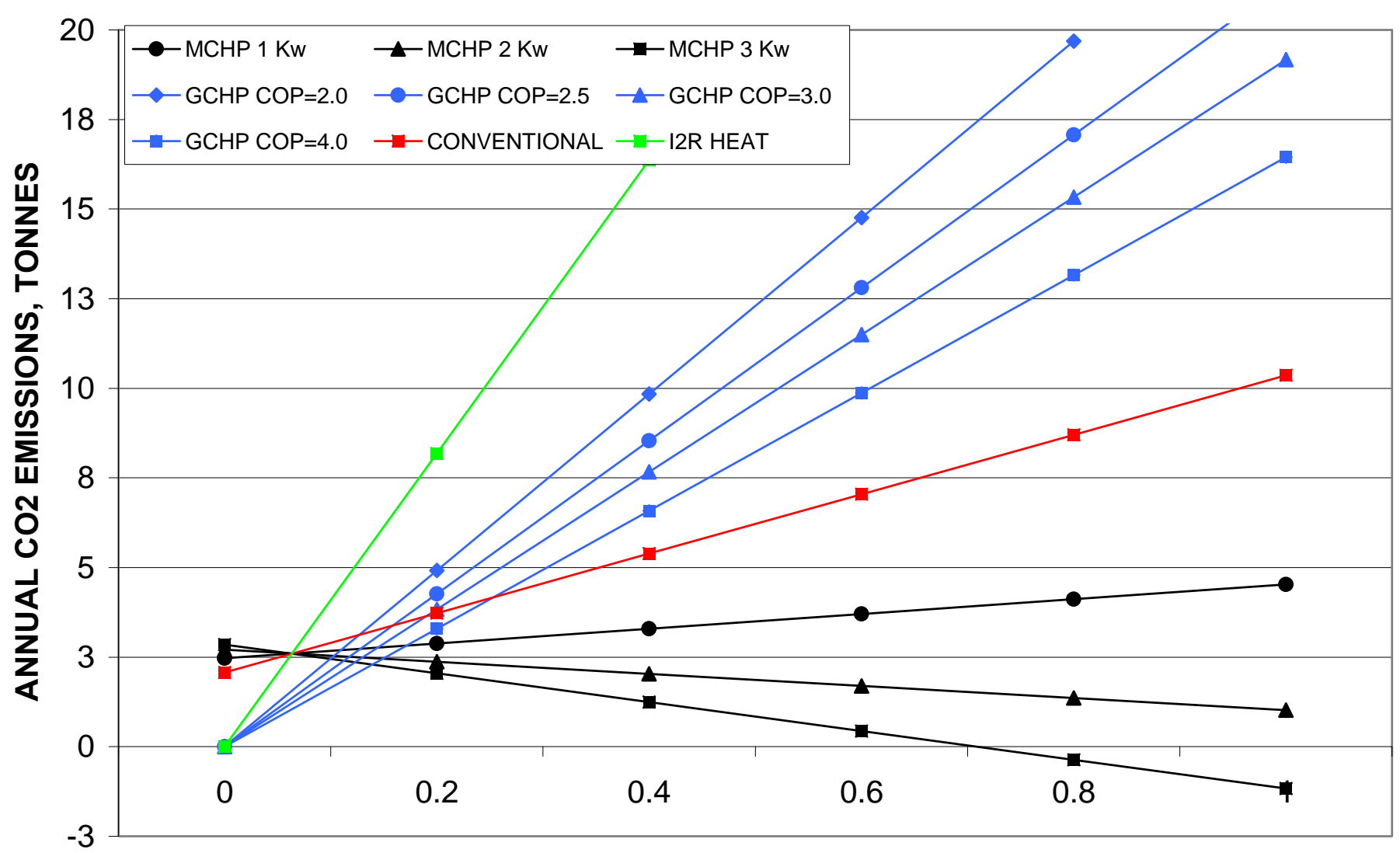

ELECTRIC UTILITY CO2 EMISSIONS RATE, kg/kWh

Figure 7-9. Carbon Dioxide Emissions Comparison as a Function of Electric Utility Emissions, Biodiesel-Fired mCHP with 25\% Electric Efficiency in Albany 
GCHP vs MCHP 25\% ELECTRIC EFFICIENCY, LONG ISLAND, BIODIESEL FIRED

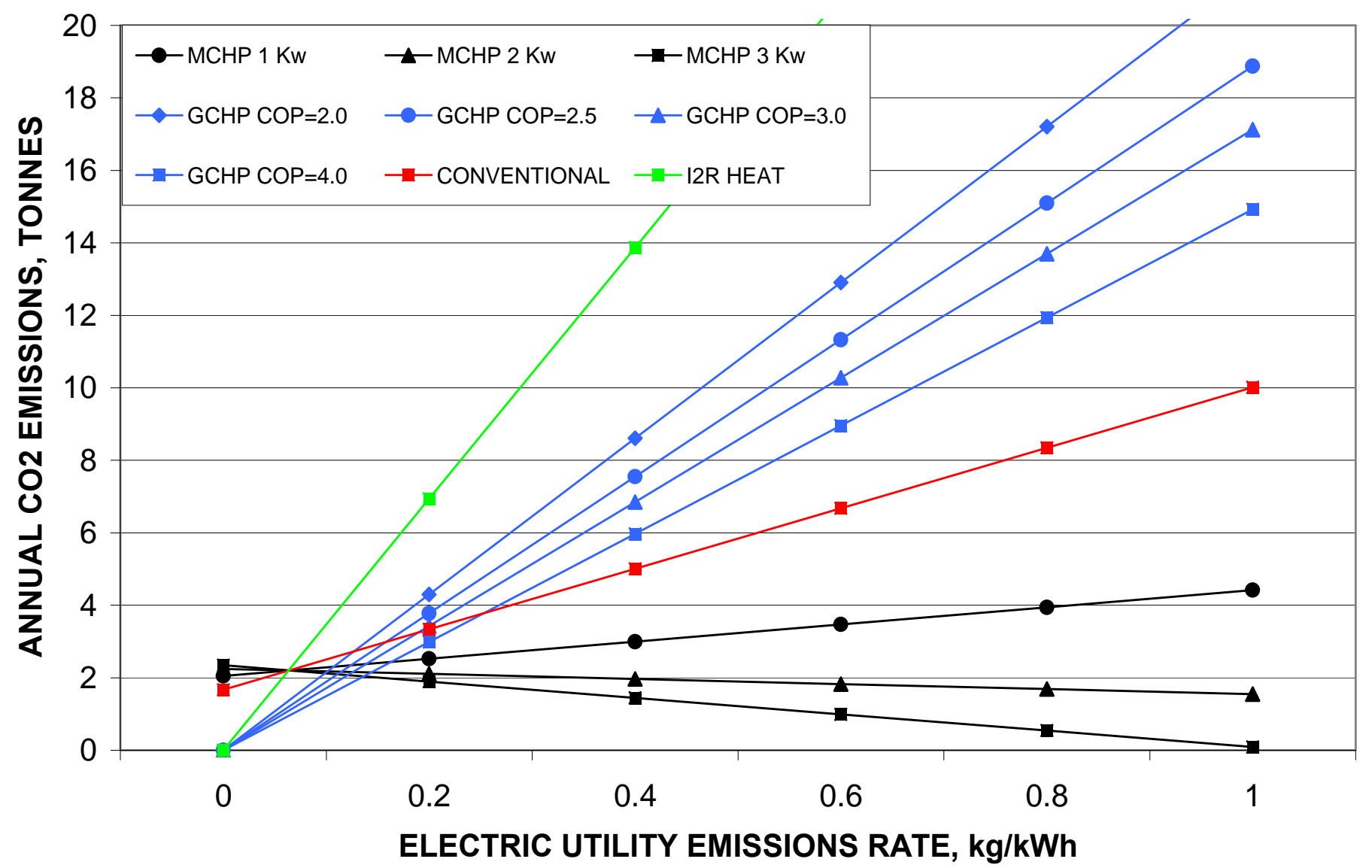

Figure 7-10. Carbon Dioxide Emissions Comparison as a Function of Electric Utility Emissions, Biodiesel-Fired mCHP with 25\% Electric Efficiency on Long Island 


\section{GCHP vs MCHP 25\% ELECTRICAL EFFICIENCY, ALBANY, B20 FIRED}

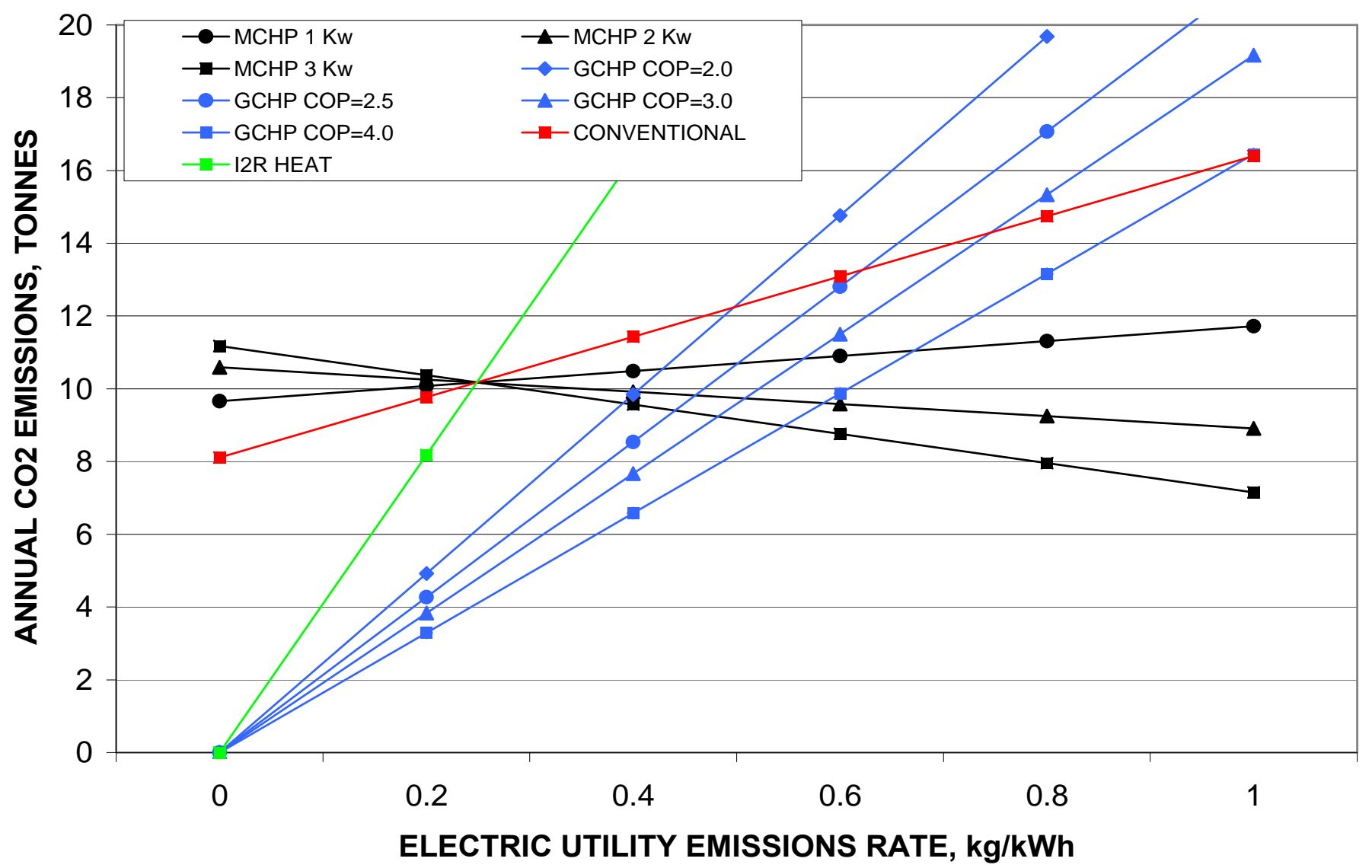

Figure 7-11. Carbon Dioxide Emissions Comparison as a Function of Electric Utility Emissions, B20 Fired mCHP with 25\% Electric Efficiency in Albany 
GCHP vs MCHP 25\% ELECTRIC EFFICIENCY, LONG ISLAND, B20 FIRED

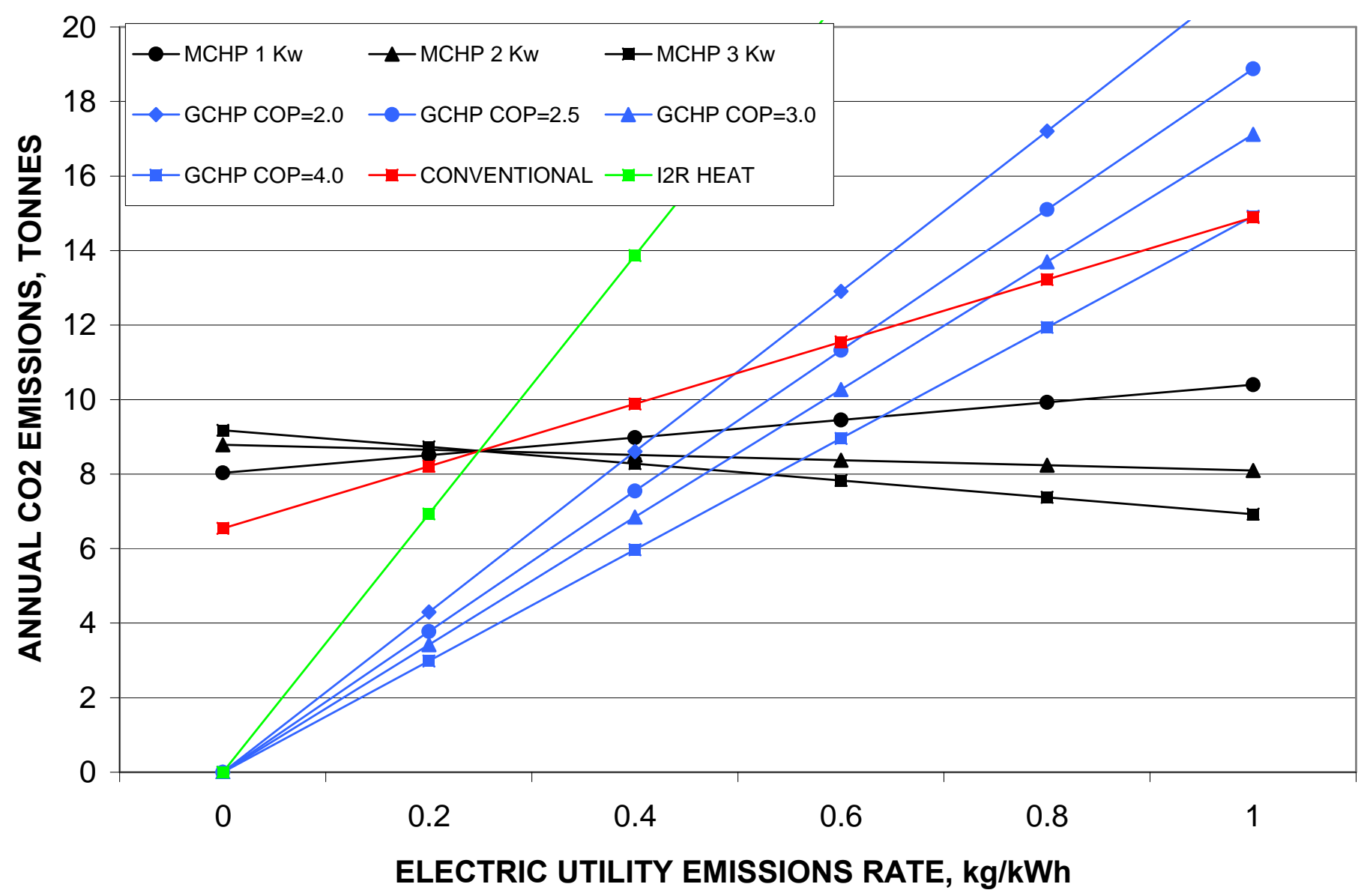

Figure 7-12. Carbon Dioxide Emissions Comparison as a Function of Electric Utility Emissions, B20 Fired mCHP with 25\% Electric Efficiency on Long Island 
GCHP vs MCHP 25\% ELECTRIC EFFICIENCY, ALBANY, B50 FIRED

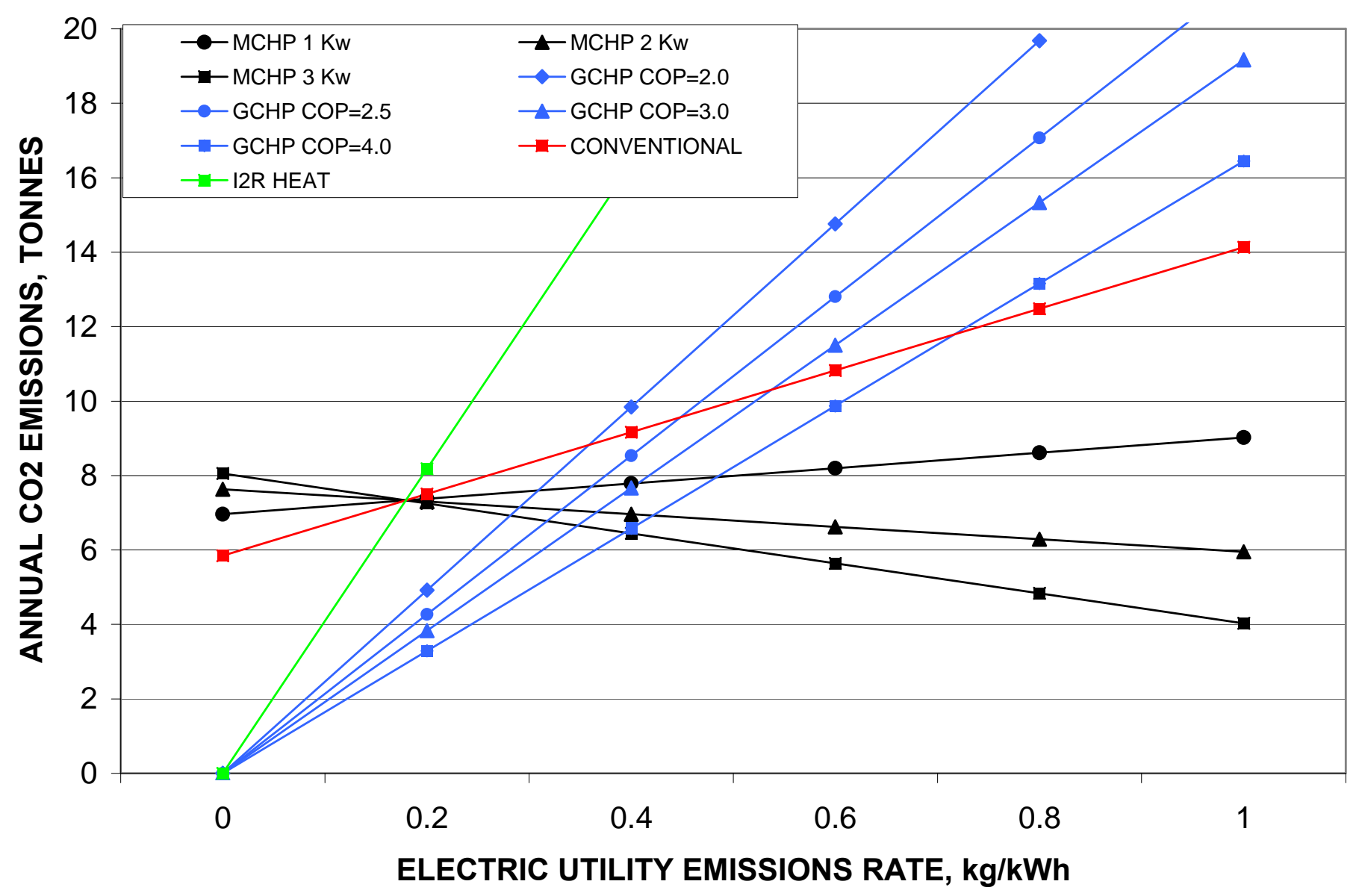

Figure 7-13. Carbon Dioxide Emissions Comparison as a Function of Electric Utility Emissions, B50 Fired mCHP with 25\% Electric Efficiency in Albany 


\section{GCHP vs MCHP 25\% ELECTRIC EFFICIENCY, LONG ISLAND, B50 FIRED}

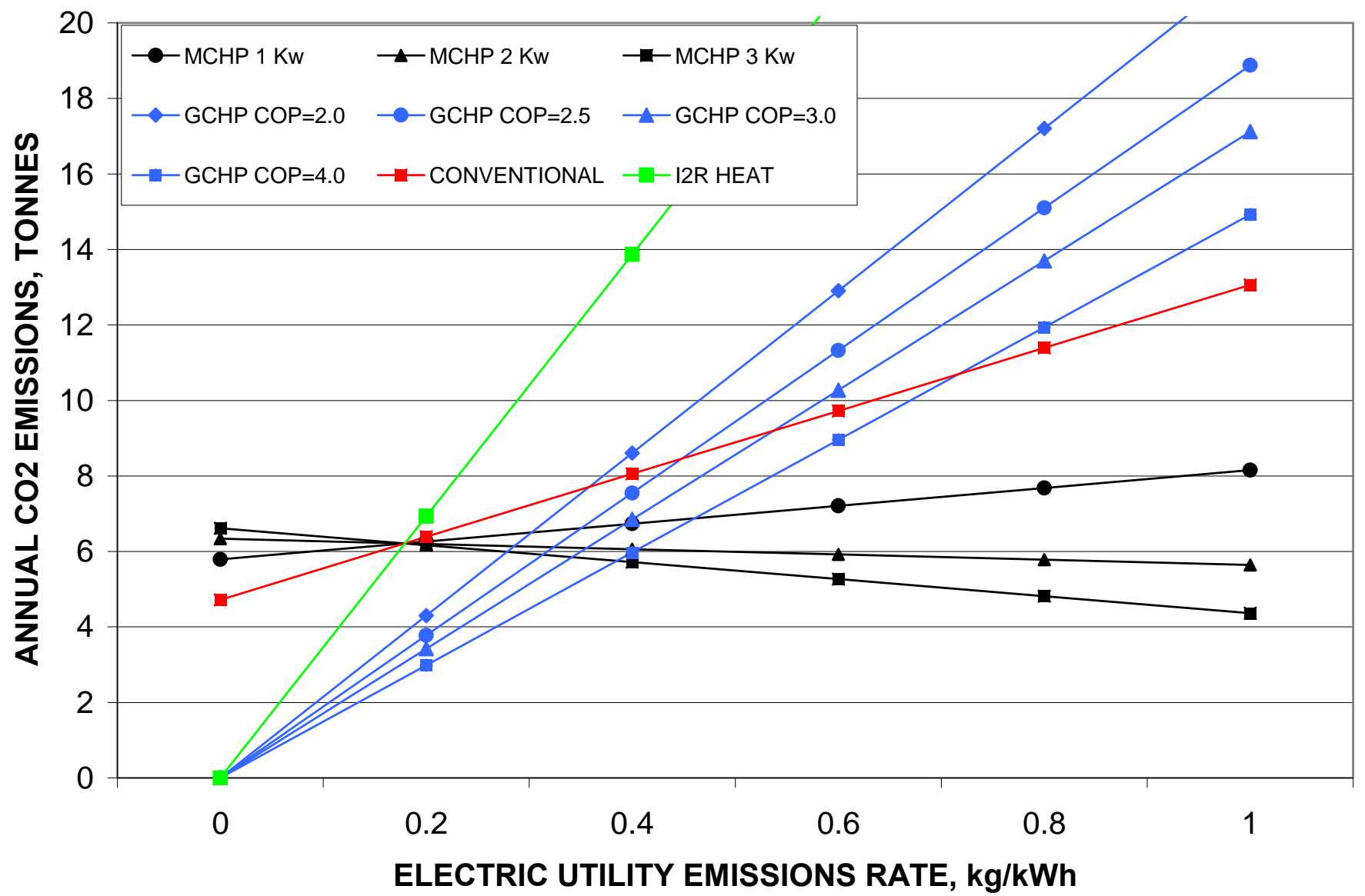

Figure 14. Carbon Dioxide Emissions Comparison as a Function of Electric Utility Emissions, B50 Fired mCHP with 25\% Electric Efficiency on Long Island 


\section{SUMMARY CONCLUSIONS}

This report has considered the prospects for residential-scale micro-cogeneration systems, in terms of information contained in the literature and an analysis of energy savings potentials with electrical and thermal efficiencies as parameters. Each section above contains a set of conclusions relating to its own subject area. Here are presented what the author believes to be the "take-home" lessons learned from the effort:

1. The salient result of this study is that the potential for energy savings in residential-scale micro-cogeneration systems is considerable, but it will not happen until a prime mover is available with the following characteristics:

- Electric output in the $0.5 \mathrm{~kW}$ to $3 \mathrm{~kW}$ range

- Reasonable first cost

- Easily maintained

- Low emissions

In particular, a worry-free 500 watt continuous-run prime mover could revolutionize the way we heat domestic water. It would also be attractive in providing the homeowner with an independent source of essential power in the event of grid failure.

2. Second only to the need for a prime mover is the need to solve the utility-interface problem. There are two divergent approaches here:

- Avoid the need for reverse metering;

- Mitigate the negative effects of reverse metering on utility load profiles.

Reverse metering may be avoided in very small systems, such as the domestic-hot-water system discussed above. It might also be achieved by providing useful on-site sinks for excess electric power, such as recharging a hybrid or electric-only vehicle.

Reverse metering might be made more acceptable to the utility by limiting the electric output of the device, by combining it with hybrid vehicle recharging, and by allowing utility control of the system during summer peak periods.

3. There is a need to place any future role of residential-scale micro-cogeneration systems in the context of competing low-energy HVAC system options such as ground-coupled heat pumps and photovoltaic-assisted systems. The impact of using biofuels as the on-site energy source (to the micro-cogeneration system or the competing conventional system) should also be considered. Any further analysis should include a wide-ranging comparison of system types with respect to technology development scenarios, future installation and operating costs, utility load impacts, and the impact of the utility generation fuel mix on the net carbon footprint of each system type. 